DOMENICA PALOMARIS MARIANO DE SOUZA

\title{
EFEITOS TÓXICOS DA SENNA OCCIDENTALIS SOBRE O SISTEMA LINFO-HEMATOPOIÉTICO: AVALIAÇÃO DA EXPOSIÇÃO DE RATOS DURANTE A FASE DE CRESCIMENTO E PRÉ-NATAL
}




\section{EFEITOS TÓXICOS DA SENNA OCCIDENTALIS SOBRE O SISTEMA LINFO-HEMATOPOIÉTICO: AVALIAÇÃO DA EXPOSIÇÃO DE RATOS DURANTE A FASE DE CRESCIMENTO E PRÉ-NATAL}

Tese apresentada ao Programa de Pós-Graduação em Patologia Experimental e Comparada da Faculdade de Medicina Veterinária e Zootecnia da Universidade de São Paulo para obtenção do título de Doutor em Ciências

Departamento:

Palologia

Área de Concentração:

Patologia Experimental e Comparada

Orientador:

Profa. Dra. Silvana Lima Górniak

São Paulo

2009 
Autorizo a reprodução parcial ou total desta obra, para fins acadêmicos, desde que citada a fonte.

DADOS INTERNACIONAIS DE CATALOGAÇÃO-NA-PUBLICAÇÃO

(Biblioteca Virginie Buff D’Ápice da Faculdade de Medicina Veterinária e Zootecnia da Universidade de São Paulo)

Souza, Domenica Palomaris Mariano de

Efeitos tóxicos da senna occidentalis sobre o sistema linfohematopoiético: avaliação da exposição de ratos durante a fase de crescimento e pré-natal / Domenica Palomaris Mariano de Souza. - São Paulo : D. P. M. Souza, 2009.

$227 \mathrm{f}$ : : il.

Tese (doutorado) - Universidade de São Paulo. Faculdade de Medicina Veterinária e Zootecnia. Departamento de Patologia, 2009.

Programa de Pós-Graduação: Patologia Experimental e Comparada. Área de concentração: Patologia Experimental e Comparada.

Orientador: Profa. Dra. Silvana Lima Górniak.

1. Ratos. 2. Senna occidentalis. 3. Plantas tóxicas. 4. Sistema linfohematopoiético. I. Título. 


\section{UNIVERSIDADE DE SÃO PAULO \\ Faculdade de Medicina Veterinária e Zootecnia \\ Cidade Universitária "Armando de Salles Oliveira"}

Comissão de Bioética

\section{CERTIFICADO}

Certificamos que o Projeto intitulado "Estudo em ratos, dos efeitos tóxicos da Senna occidentalis no sistema imune hematopoético. Avaliação em animais em crescimento e durante a gestação", protocolo n653/2005, utilizando 250 ratos, sob a responsabilidade da Profa. Dra. Silvana Lima Górniak, está de acordo com os princípios éticos de experimentação animal da Comissão de Bioética da Faculdade de Medicina Veterinária e Zootecnia da Universidade de São Paulo e foi aprovado "ad referendun".

(We certify that the Research "Study of toxic effects of Senna occidentalis in the immune and hematopoetic system. 1. Evaluation in growing rats 2.During the gestation ", protocol number 653/2005, utilizing 250 rats, under the responsibility of Prof $^{a} \mathrm{Dr}^{\mathrm{a}}$ Silvana Lima Górniak, agree with Ethical Principles in Animal Research adopted by Bioethic Commission of the Faculty of Veterinary Medicine and Zootechny of University of São Paulo and was approved "ad referendun", meeting).

São Paulo, 26 de Abril de 2005

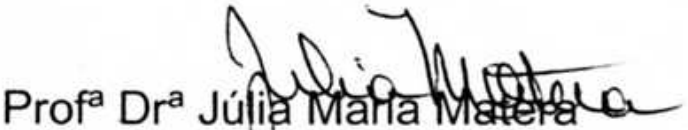

Presidente da Comissão de Bioética FMVZ/USP 


\section{FOLHA DE AVALIAÇÃO}

Nome do autor: MARIANO-SOUZA, Domenica Palomaris

Título: Efeitos tóxicos da Senna occidentalis sobre o sistema linfo-hematopoiético: avaliação da exposição de ratos durante a fase de crescimento e pré-natal

Tese apresentada ao programa de Patologia Experimental e Comparada da Faculdade de Medicina Veterinária e Zootecnia da Universidade de São Paulo para obtenção do título de Doutor em Ciências

Data:

Banca Examinadora

Prof.Dr. Instituição:

Assinatura: Julgamento:

Prof.Dr. Instituição:

Assinatura: Julgamento:

Prof.Dr. Instituição:

Assinatura: Julgamento: 


\section{DEDICATÓRIA}

* À energia mantenedora de todo universo, por me proporcionar ao longo desta caminhada, sentimentos únicos dentro deste incessante processo de criação $e$ doação, que a é vida.

* À minha mãe Marise e a minha avó Cynira, que pelas águas sagradas de seus úteros geraram o amor incondicional, este que se faz presente todos os dias, seja nas noites em claro, nos dias de incerteza e em cada etapa vivida.

* Ao meu pai Dionísio (in memoriam), pelos doces e inesquecíveis momentos que se tornaram únicos em minha vida e por todo amor dedicado durante sua vida.

* À minha amada família Mariano-Souza, por todo amor e carinho, e por fornecerem todo subsídio espiritual e familiar.

Ao meu padrasto Geraldo por todo carinho atenção e por acompanhar toda a minha trajetória, com muita paciência e bom humor.

* Ao meu amigo-irmão e companheiro Altamir por fazer parte da minha vida ao longo destes 5 anos de convivência, compartilhando sua amizade, sabedoria, conhecimento sempre oportunos. Que contribuíram para o meu crescimento pessoal e profissional.

Aos meus eternos "amigos-irmãos" Luciana Lippi, Maria Isabel, Milena Lobão, Mônica Sakai e Wanderley Quinteiro Filho, por toda solidariedade, paciência, noites em claro para a confecção desta tese e amizade irrestrita, antes durante e depois e para toda vida. Amo vocês!

* Aos animais de laboratório utilizados em meus experimentos.

Olha lá que os bravos são escravos

Sãos e salvos de sofrer

Olha lá quem acha que perderÉ ser menor na vida

Olha lá quem sempre quer vitória

E perde a glória de chorar

Eu que já não quero mais ser um vencedor

Levo a vida devagar pra não faltar amor

(O Vencedor - Marcelo Camelo) 
À Profa. Dra. Silvana Lima Górniak, por toda sua dedicação, por me acolher desde o início, por todas oportunidades oferecidas, pela confiança, orientação $e$ atenção dedicados. Especialmente na etapa final desta caminhada por ter me feito acreditar que tudo é possível, a partir do momento em que se acredita muito no que se faz.

Obrigada por tudo! 


\begin{abstract}
À Profa. Dra. Célia Aparecida Paulino, por toda sua dedicação, paciência, amizade e por toda confiança depositada em mim desde de os tempos de graduação. Pelo incentivo, preocupação e atenção dispensadas em todos os momentos vividos. Agradeço todos os dias por você fazer parte da minha. Obrigada por tudo!
\end{abstract}


Meus mais sinceros agradecimentos, a todos que de alguma forma, contribuíram durante o período de execução e realização desta Tese.

"Fundamental é mesmo o amor e é impossivel ser feliz sozinho"...

(Wave - Tom Jobim)

* Ao Departamento de Patologia Experimental e Comparada da Faculdade de Medicina Veterinária e Zootecnia (FMVZ/USP) da Universidade de São Paulo, pela oportunidade oferecida e por ter se tornado o meu segundo lar:

ش̀ Profa. Dra. Mitsue Haraguchi pela contribuição e ajuda na coleta de sementes de Senna occidentalis.

* Ao Prof. Dr. Paulo Maiorka, por toda sua amizade, contribuição e pelo seu auxílio durante as análises morfológicas dos órgãos linfóides;

* Ao Prof. Dr. Luciano Freitas Felicio por todo o seu carisma e auxílio para o término da presente tese:

* Aos funcionários da FMVZ/USP por todo carinho, convivência e atenção;

* Aos funcionários do Centro de Pesquisa Toxicológico (CEPTOX): Paulo César, Ester, Marquinhos, Estevão e Adilson, por toda receptividade e convivência ao longo destes 8 anos;

* Às bibliotecárias da FMVZ/USP, Elza Maria R. B. Faquim e Rosa Maria Fischi Zani, por toda atenção e presteza;

* Aos funcionários da biblioteca Ana Cristina, Alexandre, Elena, Solange, Paulo e Rose por todo auxílio na confecção desta dissertação, carinho e simpatia;

Aos técnicos de laboratório Magali, Marguiti, Priscila e Ricardo pelo apoio técnico prestado e pela ótima convivência;

* Aos funcionários do Biotério do VPT: Claudia, Idalina, Herculano, Nelsinho e Rosires e Mauro pelo fornecimento e cuidado com os animais utilizados neste trabalho, pela prontidão, carinho e amizade; 
* Aos funcionários do laboratório de histopatologia Cláudio Arroyo, Luciano Bugalhos, pela confecção dos cortes histológicos e auxílio prestado neste trabalho;

* As secretárias de pós-graduação Cláudia, Dayse e Joana, por toda presteza e simpatia;

* Às secretárias de Departamento Adriana, Cláudia, Silvia e D. Romeika (in memorian) por toda paciência, carinho e amizade dedicados;

* À secretária de pós-graduação Cristina Aurichi por toda dedicação, carinho $e$ amizade ao longo destes 8 anos de departamento;

* Aos meus eternos irmãos científicos: Altamir, Andréia, Benito, Breno, Helena, Isis, Luciana Lippi, Marcos e Stella por todo companheirismo e ajuda para a realização deste e de futuros trabalhos e pelos bons momentos de descontração;

* Aos meus amigos Alexandra Nicolau, Alexandre (Carioca), Cristina Massoco, Daniel Cohn,Daniel Sanches, Denise, Eduardo Zarzana, Elaine, Evelise, Fabiana Godoy, Fabio Ribeiro, Frederico, Glaucie, Heidge, Idalina, Lilian, Livia e Luciano Bugalhos, Luciana Torres, Renato, Ricardo Lazarini, Silvia Oloris e Tereza, por toda convivência e por contribuírem de forma impar para minha formação. Aprendi muito com vocês!

* $A$ todos os colegas de pós-graduação pela agradável convivência;

* Aos meus amigos de prontidão, por toda choradeira, reclamação e constante ausência ao longo da graduação e pós-graduação. Amo vocês!

* $A r^{a}$ Nadir Ossanha pela maravilhosa convivência nestes últimos 2 anos que resultaram em um aprendizado para toda a vida;

* Ao Conselho Nacional de Desenvolvimento Científico e Tecnologia ( $C N P q)$ pelo financiamento desta pesquisa. 


\section{RESUMO}

MARIANO-SOUZA, D. P. Efeitos tóxicos da Senna occidentalis sobre o sistema linfohematopoiético: avaliação da exposição de ratos durante a fase de crescimento e prénatal. [Toxic effects of Senna occidentalis on lymphohematopoetic system: evaluation of its exposure in rats during the growth and pre-natal period]. 2009. $227 \mathrm{f}$. Tese (Doutorado em Ciências) - Faculdade de Medicina Veterinária e Zootecnia, Universidade de São Paulo, São Paulo, 2009.

O objetivo do presente estudo foi avaliar os efeitos tóxicos da Senna occidentalis (So) sobre o sistema linfo-hematopoiético em ratos recém-desmamados ou expostos prénatalmente. Avaliou-se nestes animais: o consumo de água e ração, o ganho de peso; parâmetros hematológicos, padrões histopatológicos, além da resposta imunológica específica e não específica. Inicialmente, o estudo foi realizado em ratos recémdesmamados, os quais foram expostos a diferentes concentrações de sementes de So na ração a saber: $1 \%$ (So1), $2 \%$ (So2) e $4 \%$ (So4) durante 14 dias ou que receberam So4 durante 28 dias. Os animais do grupo peer-feeding (PF) receberam a mesma quantidade de ração consumida pelos animais expostos a So4, porém isentas da planta. Após 14 dias de exposição, os resultados obtidos mostraram uma diminuição significante nos parâmetros de consumo de ração, de ganho de peso e da celularidade da medula óssea e do peso relativo no timo nos grupos So2 e So4 e um aumento no peso relativo do baço nos grupos So2 e So4. Entretanto, os animais dos grupos So4 e PF também apresentaram diminuição da celularidade da medula óssea. Na avaliação da resposta imune não especifica todos grupos expostos às sementes da planta, bem como o grupo PF, apresentaram redução na porcentagem de fagocitose por neutrófilos; porém, apenas o grupo So4 mostrou redução do burst basal por neutrófilos. O estudo morfológico do baço mostrou proliferação hematopoiética extramedular e aumento de megacariócitos multinucleados nos ratos do grupo So4. Apenas nos experimentos com animais do grupo So4 expostos por 28 dias, verificou-se similaridade entre resultados dos parâmetros acima descritos, além da ocorrência de anemia microcítica e hipocrômica. Num segundo momento avaliou-se as proles de ratas que receberam sementes de S. occidentalis a $4 \%$ na ração, do $6^{\circ}$ ao $20^{\circ}$ dia de gestação, assim como as proles das ratas do grupo peer-feeding (PF). Os filhotes provenientes de mães do grupo So4 e PF apresentaram um aumento do burst oxidativo e da fagocitose por neutrófilos. Os animais da prole do grupo PF apresentaram hemograma indicativo de anemia megaloblástica. Já no estudo morfológico do baço verificou-se hematopoiese extramedular nos filhotes das mães do grupo So4. Portanto, a presente pesquisa mostrou que a $S$. occidentalis pode comprometer alguns parâmetros do sistema imunológico de ratos expostos às sementes da planta durantes diferentes fases do desenvolvimento. Além disso, verificou-se que as sementes desta planta também promovem efeitos tóxicos sobre eritrócitos. A inclusão do grupo PF permitiu verificar que os efeitos observados não são decorrentes de possíveis alterações nutricionais promovidas pela redução do consumo de ração, mas sim relacionados ao efeito tóxico direto da S. occidentalis.

Palavras-chaves: Ratos. Senna occidentalis. Plantas tóxicas. Sistema linfohematopoiético. 


\begin{abstract}
MARIANO-SOUZA, D. P. Toxic effects of Senna occidentalis on lymphohematopoetic system: evaluation of its exposure in rats during the growth and pre-natal period [Efeitos tóxicos da Senna occidentalis sobre o sistema linfo-hematopoiético: avaliação da exposição de ratos durante a fase de crescimento e pré-natal]. 2009. $227 \mathrm{f}$. Tese (Doutorado em Ciências) - Faculdade de Medicina Veterinária e Zootecnia, Universidade de São Paulo, São Paulo, 2009.

The aim of present study was to determinate the Senna occidentalis (So) toxic effects on lymphohematopoetic system in rats during the growth and pre-natal period. The effects were evaluated on the basis of food consumption, weight gain, hematological and immunological parameters, as well as histopathology analysis. Initially, the study was done in growing rats exposed to $S$. occidentalis seeds in different concentrations: $1 \%$ (So1), 2\% (So2) and 4\% (So4) in feed during 14 or 28 days. Peer feeding-group of rats (PF) was also evaluated; this group received the same amount of feed of those from So4-group, however, free of $S$. occidentalis seeds. S. occidentalis 14 days exposure decreased food consumption, weight gain, thymus relative organ weight and bone marrow cellularity and increased the spleen relative weight of rats from So2 and So4-group. However, So4- and PF- groups also presented a decreased bone marrow cellularity. All seed exposed-groups and also PF-group had a decrease on neutrophil phagocytosis percentage; however, only rats from So4-group had a decreased neutrophil basal burst. Spleen morphologic analysis indicated the presence of extramedular hematopoietic proliferation and increased multinucleated megakariocytes on So4-group. Similar results were found for all the parameters described after $S$. occidentalis exposure during 28 days. Furthermore, the rats of So-4 group presented microcytic and hypochromic anemia. On a second moment, rats offspring exposed to $S$. occidentalis at $4 \%$ in feed during the $6^{\text {th }}$ to $20^{\text {th }}$ gestational day and rats offspring of $P F$ group were evaluated. The So4- and PF- rats offspring groups presented an increased neutrophil oxidative burst and phagocytosis, however PF-rats offspring group also had an altered complete blood count compatible with megaloblastic anemia. Moreover spleen morphologic analysis indicated the presence of extramedular hematopoiesis on So4 rats offspring group. Therefore, the present study showed that $S$. occidentalis can compromise some immunological parameters in rats exposed to seeds during different development periods. This exposure also promotes toxic effects on erythrocytes. The PF group allowed us to verify that the observed effects are related to direct $S$. occidentalis toxic effects and not due a possible nutritional alteration caused by the reduced feed ingestion.
\end{abstract}

Key words: Rats. Senna occidentalis. Poisonous Plants. Animal Pathology. 


\section{LISTA DE TABELAS}

Tabela 1- Consumo médio e total de ração (em g) pelos ratos recémdesmamados tratados durante 14 dias com diferentes concentrações $(0 \%, 1 \%, 2 \%$ e $4 \%)$ de sementes de S. occidentalis, na ração. Foram utilizados 10 animais por grupo. São apresentados as medias e os respectivos desvios padrões.

Tabela 2- Peso médio (em g), de ratos recém-desmamados tratados durante 14 dias com diferentes concentrações $(0 \%, 1 \%, 2 \%$ e $4 \%)$ de sementes de $S$. occidentalis, na ração e seu grupo peer-feeding (PF). Foram utilizados 10 animais por grupo. São apresentados as medias e os respectivos desvios padrões.

Tabela 3- Peso semanal e total (em g), de ratos recém-desmamados tratados durante 14 dias com diferentes concentrações ( $0 \%, 1 \%, 2 \%$ e $4 \%)$ de sementes de $S$. occidentalis, na ração e seu grupo peer-feeding. Foram utilizados 10 animais por grupo. São apresentados as medias e os respectivos desvios padrões.

Tabela 4- Número médio de eritrócitos $\left(\times 10^{6} / \mathrm{mm}^{3}\right)$ e leucócitos $\left(\times 10^{6} / \mathrm{mm}^{3}\right)$ e os valores médios do hematócrito - HCT (\%) e hemoglobina - $\mathrm{Hb}$ $(\mathrm{g} / \mathrm{dL})$, volume corpuscular médio - $\operatorname{VCM}\left(\mu^{3}\right)$, hemoglobina corpuscular média - HCM ( $\mu \mu \mathrm{g})$ e concentração de hemoglobina corpuscular média - $\mathrm{CHCM}(\%)$, de ratos recém-desmamados tratados durante 14 dias com diferentes concentrações $(0 \%, 1 \%$, $2 \%$ e $4 \%$ ) de sementes de $S$. occidentalis, na ração e seu grupo peer-feeding (PF). Foram utilizados 10 animais por grupo. São apresentados as medias e os respectivos desvios padrões.

Tabela 5- Média do número de linfócitos (em \%), neutrófilos segmentados (em\%), eosinófilos (em \%), bastonete (em \%) e monócitos (em \%), de ratos recém-desmamados tratados durante 14 dias com diferentes concentrações $(0 \%, 1 \%, 2 \%$ e $4 \%)$ de sementes de $S$. occidentalis, na ração e seu grupo peer-feeding (PF). Foram utilizados 10 animais por grupo. São apresentados as medias e os respectivos desvios padrões. 
Tabela 6- Peso relativo do baço e timo ( $\mathrm{g} / 100 \mathrm{~g} \mathrm{pv}$ ), de ratos recémdesmamados tratados durante 14 dias com diferentes concentrações $(0 \%, 1 \%, 2 \%$ e $4 \%)$ de sementes de $S$. occidentalis, na ração e seu grupo peer-feeding (PF). Foram utilizados 10 animais por grupo. São apresentados as médias e os respectivos desvios padrões.

Tabela 7- Celularidade do baço e da medula óssea (x 106/cel), de ratos recém-desmamados tratados durante 14 dias com diferentes concentrações $(0 \%, 1 \%, 2 \%$ e $4 \%)$ de sementes de $S$. occidentalis, na ração e seu grupo peer-feeding (PF). Foram utilizados 10 animais por grupo. São apresentados as médias e os respectivos desvios padrões.

Tabela 8- Consumo médio e total de ração (em g) pelos ratos recémdesmamados tratados durante 14 dias com diferentes concentrações $(0 \%, 1 \%, 2 \%$ e $4 \%)$ de sementes de $S$. occidentalis, na ração. Foram utilizados 10 animais por grupo. São apresentados as médias e os respectivos desvios padrões.

Tabela 9- Peso médio (em $\mathrm{g}$ ), de ratos recém-desmamados tratados durante 14 dias com diferentes concentrações $(0 \%, 1 \%, 2 \%$ e $4 \%)$ de sementes de $S$. occidentalis, na ração e seu grupo peer-feeding (PF). Foram utilizados 10 animais por grupo. São apresentados as médias e os respectivos desvios padrões.

Tabela 10- Peso semanal e total (em g), de ratos recém-desmamados tratados durante 14 dias com diferentes concentrações ( $0 \%, 1 \%, 2 \%$ e $4 \%)$ de sementes de $S$. occidentalis, na ração e seu grupo peer-feeding (PF). Foram utilizados 10 animais por grupo. São apresentados as médias e os respectivos desvios padrões.

Tabela 11- Avaliação do burst oxidativo e da fagocitose de neutrófilos, de ratos recém-desmamados tratados durante 14 dias com diferentes concentrações $(0 \%, 1 \%, 2 \%$ e $4 \%)$ de sementes de $S$. occidentalis, na ração e seu grupo peer- feeding (PF). Foram utilizados 10 animais por grupo. São apresentados as médias e os respectivos desvios padrões.

Tabela 12- Consumo médio e total de ração (g) pelos ratos recémdesmamados tratados durante 14 dias com diferentes concentrações $(0 \%, 1 \%, 2 \%$ e $4 \%)$ de sementes de $S$. occidentalis, na ração. Foram utilizados 10 animais por grupo. São apresentados as médias e os respectivos desvios padrões 
Tabela 13- $\quad$ Peso médio (g), de ratos recém-desmamados tratados durante 14 dias com diferentes concentrações $(0 \%, 1 \%, 2 \%$ e $4 \%)$ de sementes de $S$. occidentalis, na ração e seu grupo peer-feeding (PF). Foram utilizados 10 animais por grupo. São apresentados as médias e os respectivos desvios padrões.

Tabela 14 Peso semanal e total $(\mathrm{g})$, de ratos recém-desmamados tratados durante 14 dias com diferentes concentrações $(0 \%, 1 \%, 2 \%$ e $4 \%)$ de sementes de $S$. occidentalis, na ração e seu grupo peer-feeding (PF). Foram utilizados 10 animais por grupo. São apresentados as médias e os respectivos desvios padrões.

Tabela 15- Mensuração do edema induzido pela inoculação de 0,1 ml de BSA no coxim plantar de ratos recém-desmamados durante 14 dias com diferentes concentrações $(0,1 \%, 2 \%$ e $4 \%)$ de sementes de S. occidentalis na ração e seu grupo peer-feeding (PF). Foram utilizados 10 animais por grupo. São apresentados as médias e os respectivos desvios padrões.

Tabela 16- Consumo médio e total de ração (em g) pelos ratos recémdesmamados tratados durante 28 dias com 0 e $4 \%$ de sementes de S. occidentalis, na ração. Foram utilizados 10 animais por grupo. São apresentados as médias e os respectivos desvios padrões

Tabela 17- Peso médio (em g), de ratos recém-desmamados tratados durante 28 dias com 0 e 4\% de sementes de $S$. occidentalis, na ração e seu grupo peer-feeding (PF). Foram utilizados 10 animais por grupo. São apresentados as médias e os respectivos desvios padrões.

Tabela 18- Peso semanal e total (em g), de ratos recém-desmamados tratados durante 28 dias com 0 e $4 \%$ de sementes de $S$. occidentalis, na ração e seu grupo peer-feeding (PF). Foram utilizados 10 animais por grupo. São apresentados as médias e os respectivos desvios padrões.

Tabela 19- Número médio de eritrócitos $\left(\times 10^{6} / \mathrm{mm}^{3}\right)$ e leucócitos $\left(\times 10^{6} / \mathrm{mm}^{3}\right)$ e os valores médios do hematócrito - HCT (\%) e hemoglobina - $\mathrm{Hb}$ $(\mathrm{g} / \mathrm{dL})$, volume corpuscular médio - VCM $\left(\mu^{3}\right)$, hemoglobina corpuscular média - HCM $(\mu \mu \mathrm{g})$ e concentração de hemoglobina corpuscular média - CHCM (\%), de ratos recém-desmamados tratados durante 28 dias com 0 e $4 \%$ de sementes de S. occidentalis, na ração e seu grupo peer-feeding. Foram utilizados 10 animais por grupo. São apresentados as médias e os respectivos desvios padrões. 
Tabela 20- Média do número de linfócitos (em \%), neutrófilos segmentados (em\%), eosinófilos (em \%), bastonete (em \%) e monócitos (em \%), de ratos recém-desmamados tratados durante 28 dias com 0 e $4 \%$ de sementes de $S$. occidentalis, na ração e seu grupo peer-feeding (PF). Foram utilizados 10 animais por grupo. São apresentados as médias e os respectivos desvios padrões.

Tabela 21- Peso relativo do baço e timo $(\mathrm{g} / 100 \mathrm{~g} \mathrm{pv})$, de ratos recémdesmamados tratados durante 28 dias com 0 e $4 \%$ de sementes de S. occidentalis, na ração e seu grupo peer-feeding (PF). Foram utilizados 10 animais por grupo. São apresentados as médias e os respectivos desvios padrões.

Tabela 22- Celularidade do baço e da medula óssea (x 10\% $/ \mathrm{cel}$ ), de ratos recém-desmamados tratados durante 28 dias com 0 e $4 \%$ de sementes de $S$. occidentalis, na ração e seu grupo peer-feeding (PF). Foram utilizados 10 animais por grupo. São apresentados as médias e os respectivos desvios padrões.

Tabela 23- Consumo médio e total de ração (em g) pelos ratos recémdesmamados tratados durante 28 dias com 0 e $4 \%$ de sementes de S. occidentalis, na ração. Foram utilizados 10 animais por grupo. São apresentados as médias e os respectivos desvios padrões

Tabela 24- Peso médio (em $\mathrm{g}$ ), de ratos recém-desmamados tratados durante 28 dias com 0 e $4 \%$ de sementes de $S$. occidentalis, na ração e seu grupo peer-feeding (PF). Foram utilizados 10 animais por grupo. São apresentados as médias e os respectivos desvios padrões.......

Tabela 25- Peso semanal e total (em g), de ratos recém-desmamados tratados durante 28 dias com 0 e $4 \%$ de sementes de $S$. occidentalis, na ração e seu grupo peer-feeding (PF). Foram utilizados 10 animais por grupo. São apresentados as médias e os respectivos desvios padrões.

Tabela 26- Avaliação do burst oxidativo e da fagocitose de neutrófilos, de ratos recém-desmamados tratados durante 28 dias com 0 e $4 \%$ de sementes de sementes de $S$. occidentalis, na ração e seu grupo peer-feeding (PF). Foram utilizados 10 animais por grupo. São apresentados as médias e os respectivos desvios padrões

Tabela 27- Consumo médio e total de ração $(\mathrm{g})$ pelas ratas tratadas do $6^{\circ}$ ao $20^{\circ}$ dias de gestação com diferentes concentrações $(0 \%, 1 \%, 2 \%$ e $4 \%$ ) de sementes de $S$. occidentalis, na ração. Foram utilizados 8 animais por grupo. São apresentados as médias e os respectivos desvios padrões. 
Tabela 28- Peso médio $(\mathrm{g})$, de ratas tratadas do $6^{\circ}$ ao $20^{\circ}$ dias de gestação com diferentes concentrações $(0 \%, 1 \%, 2 \%$ e $4 \%)$ de sementes de S. occidentalis, na ração e seu grupo peer-feeding (PF). Foram utilizados 8 animais por grupo. São apresentados as médias e os respectivos desvios padrões.

Tabela 29- Peso semanal e total (g), de ratas tratadas do $6^{\circ}$ ao $20^{\circ}$ dias de gestação com diferentes concentrações $(0 \%, 1 \%, 2 \%$ e $4 \%)$ de sementes de $S$. occidentalis, na ração e seu grupo peer-feeding (PF). Foram utilizados 8 animais por grupo. São apresentados as médias e os respectivos desvios padrões.

Tabela 30- Desempenho reprodutivo de ratas tratadas do $6^{\circ}$ ao $20^{\circ}$ dias de gestação com diferentes concentrações $(0 \%, 1 \%, 2 \%$ e $4 \%)$ de sementes de $S$. occidentalis, na ração e seu grupo peer-feeding (PF). Foram utilizados 8 animais por grupo. São apresentados as médias e os respectivos desvios padrões.

Tabela 31- Número médio de eritrócitos $\left(\times 10^{6} / \mathrm{mm}^{3}\right)$ e leucócitos $\left(\times 10^{6} / \mathrm{mm}^{3}\right)$ de ratas tratadas do $6^{\circ}$ ao $20^{\circ}$ dias de gestação com diferentes concentrações $(0 \%, 1 \%, 2 \%$ e $4 \%)$ de sementes de $S$. occidentalis, na ração e seu grupo peer-feeding (PF). Foram utilizados 8 animais por grupo. São apresentados as médias e os respectivos desvios padrões.

Tabela 32- Média do número de linfócitos (em \%), neutrófilos segmentados (em\%), eosinófilos (em \%), bastonete (em \%) e monócitos (em \%), de ratas tratadas do $6^{\circ}$ ao $20^{\circ}$ dias de gestação com diferentes concentrações $(0 \%, 1 \%, 2 \%$ e $4 \%)$ de sementes de $S$. occidentalis, na ração e seu grupo peer-feeding (PF). Foram utilizados 8 animais por grupo. São apresentados as médias e os respectivos desvios padrões.

Tabela 33- Peso relativo do baço $(\mathrm{g} / 100 \mathrm{~g} \mathrm{pv})$, de ratas tratadas do $6^{\circ}$ ao $20^{\circ}$ dias de gestação com diferentes concentrações ( $0 \%, 1 \%, 2 \%$ e $4 \%)$ de sementes de $S$. occidentalis, na ração e seu grupo peer-feeding. Foram utilizados 8 animais por grupo. São apresentados as médias e os respectivos desvios padrões.

Tabela 34- Celularidade do baço e da medula óssea (x 10\% $/ \mathrm{cel}$ ), de ratas tratadas do $6^{\circ}$ ao $20^{\circ}$ dias de gestação com diferentes concentrações $(0 \%, 1 \%, 2 \%$ e $4 \%)$ de sementes de $S$. occidentalis, na ração e seu grupo peer-feeding (PF). Foram utilizados 8 animais por grupo. São apresentados as médias e os respectivos desvios padrões. 
Tabela 35- Consumo médio e total de ração $(\mathrm{em} \mathrm{g})$ pelas ratas tratadas do $6^{\circ}$ ao $20^{\circ}$ dias de gestação com 0 e $4 \%$ de sementes de S. occidentalis na ração. Foram utilizados 10 animais por grupo. São apresentados as médias e os respectivos desvios padrões

Tabela 36- Peso médio (em g), de ratas tratadas do $6^{\circ}$ ao $20^{\circ}$ dias de gestação com 0 e $4 \%$ de sementes de $S$. occidentalis naração e seu grupo peer-feeding (PF). Foram utilizados 10 animais por grupo. São apresentados as médias e os respectivos desvios padrões.

Tabela 37- Peso semanal e total (em g), de ratas tratadas do $6^{\circ}$ ao $20^{\circ}$ dias de gestação com 0 e $4 \%$ de sementes de $S$. occidentalis na ração e seu grupo peer-feeding (PF). Foram utilizados 10 animais por grupo. São apresentados as médias e os respectivos desvios padrões

Tabela 38- Parâmetros reprodutivos de ratas que consumiram 0 e $4 \%$ de sementes de $S$. occidentalis na ração do $6^{\circ}$ ao $20^{\circ}$ dia de gestação, e seu grupo peer-feeding (PF). Foram utilizados 10 animais por grupo. São apresentados as médias e os respectivos desvios padrões

Tabela 39- Peso médio (em g), da prole de ratas tratadas com 0 e $4 \%$ de sementes de $S$. occidentalis na ração e seu grupo peer-feeding (PF). Foram utilizados 10 animais por grupo. São apresentados as médias e os respectivos desvios padrões.

Tabela 40- Peso semanal e total (em g), da prole de ratas tratadas com 0 e $4 \%$ de sementes de $S$. occidentalis na ração e seu grupo peer-feeding (PF). Foram utilizados 10 animais por grupo. São apresentados as médias e os respectivos desvios padrões.

Tabela 41- Número médio de eritrócitos $\left(\times 10^{6} / \mathrm{mm}^{3}\right)$ e leucócitos $\left(\times 10^{6} / \mathrm{mm}^{3}\right)$ e os valores médios do hematócrito - HCT (\%) e hemoglobina - Hb $(\mathrm{g} / \mathrm{dL})$, volume corpuscular médio - $\operatorname{VCM}\left(\mu^{3}\right)$, hemoglobina corpuscular média - HCM $(\mu \mu \mathrm{g})$ e concentração de hemoglobina corpuscular média - CHCM (\%), da prole de ratas tratadas com 0 e $4 \%$ de sementes de $S$. occidentalis na ração e seu grupo peerfeeding (PF). Foram utilizados 10 animais por grupo. São apresentados as médias e os respectivos desvios padrões 
Tabela 42- Média do número de linfócitos (em \%), neutrófilos segmentados (em\%), eosinófilos (em \%), bastonete (em \%) e monócitos (em \%), da prole de ratas tratadas com 0 e $4 \%$ de sementes de $S$. occidentalis na ração e seu grupo peer-feeding (PF). Foram utilizados 10 animais por grupo. São apresentados as médias e os respectivos desvios padrões.

Tabela 43- Peso relativo do baço e timo (g/ $100 \mathrm{~g} \mathrm{pv}$ ), da prole de ratas tratadas com 0 e $4 \%$ de sementes de $S$. occidentalis na ração e seu grupo peer-feeding (PF). Foram utilizados 10 animais por grupo. São apresentados as médias e os respectivos desvios padrões

Tabela 44- Celularidade do baço e da medula óssea (x $\left.10^{6} / \mathrm{cel}\right)$, da prole de ratas tratadas com 0 e $4 \%$ de sementes de $S$. occidentalis na ração e seu grupo peer-feeding (PF). Foram utilizados 10 animais por grupo. São apresentados as médias e os respectivos desvios padrões

Tabela 45- Avaliação do burst oxidativo e da fagocitose por neutrófilos, da prole de ratas tratadas com 0 e $4 \%$ de sementes de $S$. occidentalis na ração e seu grupo peer-feeding (PF). Foram utilizados 10 animais por grupo. São apresentados as médias e os respectivos desvios padrões.

Tabela 46- Mensuração do edema induzido pela inoculação de 0,1 ml de BSA no coxim plantar de ratas fêmeas, da prole de ratas tratadas com 0 e $4 \%$ de sementes de $S$. occidentalis na ração e seu grupo peerfeeding (PF). Foram utilizados 10 animais por grupo. São apresentados as médias e os respectivos desvios padrões. 


\section{LISTA DE FIGURAS}

Figura 1 - Senna occidentalis (KISSMANN, K. G; GROTH, D. Plantas infestantes e nocivas, tomo II, BASF, 1995)...

Figura 2 - Representação esquemática de sequências de reagentes utilizados nas técnicas de burst oxidativo e fagocitose.

Figura 3 - Consumo médio e total de ração (em g) pelos ratos recémdesmamados tratados durante 14 dias com diferentes concentrações $(0 \%, 1 \%, 2 \%$ e $4 \%)$ de sementes de S. occidentalis, na ração. Foram utilizados 10 animais por grupo São apresentados as médias e os respectivos desvios padrões.

Figura 4 - Peso médio (em g), de ratos recém-desmamados tratados durante 14 dias com diferentes concentrações $(0 \%, 1 \%, 2 \%$ e $4 \%)$ de sementes de $S$. occidentalis, na ração e seu grupo peer-feeding (PF). Foram utilizados 10 animais por grupo. São apresentados as médias e os respectivos desvios padrões.

Figura 5 - Peso semanal e total (em g), de ratos recém-desmamados tratados durante 14 dias com diferentes concentrações (0\%, 1\%, 2\% e 4\%) de sementes de $S$. occidentalis, na ração e seu grupo peer-feeding (PF). Foram utilizados 10 animais por grupo. São apresentados as médias e os respectivos desvios padrões.

Figura 6 - Peso relativo do baço e do timo ( $\mathrm{g} / 100 \mathrm{~g} \mathrm{pv})$, de ratos recémdesmamados tratados durante 14 dias com diferentes concentrações $(0 \%, 1 \%, 2 \%$ e $4 \%)$ de sementes de S. occidentalis, na ração e seu grupo peer-feeding (PF). Foram utilizados 10 animais por grupo. São apresentados as médias e os respectivos desvios padrões.

Figura 7 - Celularidade da medula óssea (x 10\% /cel), de ratos recémdesmamados tratados durante 14 dias com diferentes concentrações $(0 \%, 1 \%, 2 \%$ e $4 \%)$ de sementes de S. occidentalis, na ração e seu grupo peer-feeding (PF). Foram utilizados 10 animais por grupo. São apresentados as médias e os respectivos desvios padrões. 
Figura 8 - Fotomicrográfia do baço de ratos recém-desmamados tratados durante 14 dias com sementes de $S$. occidentalis na ração. A. Integridade do parênquima esplênico com linfonodos bem delimitados, animal controle. B. Aumento do tamanho dos folículos linfóides e presença de megacariócitos (M), nos ratos do grupo So4\% (seta). C. Megacariócitos (M) visíveis com núcleo multilobulado e nucléolos proeminentes (seta), nos ratos do grupo So4\%. D. Progenitores eritróides em diferentes estágios de maturação (seta) nos ratos do grupo So4\%. (H.E. 40x).

Figura 9 - Peso médio (em g), de ratos recém-desmamados tratados durante 14 dias com diferentes concentrações $(0 \%, 1 \%, 2 \%$ e $4 \%)$ de sementes de $S$. occidentalis, na ração e seu grupo peer-feeding (PF). Foram utilizados 10 animais por grupo. São apresentados as médias e os respectivos desvios padrões.

Figura 10 - Peso semanal e total (em g), de ratos recém-desmamados tratados durante 14 dias com diferentes concentrações ( $0 \%, 1 \%, 2 \%$ e 4\%) de sementes de $S$. occidentalis, na ração e seu grupo peer-feeding (PF). Foram utilizados 10 animais por grupo. São apresentados as médias e os respectivos desvios padrões.

Figura 11 - Avaliação do burst oxidativo e da fagocitose de neutrófilos, de ratos recém-desmamados tratados durante 14 dias com diferentes concentrações $(0 \%, 1 \%, 2 \%$ e $4 \%)$ de sementes de S. occidentalis, na ração e seu grupo peer-feeding (PF). Foram utilizados 10 animais por grupo. São apresentados as médias e os respectivos desvios padrões

Figura 12 - Consumo médio e total de ração (g) pelos ratos recémdesmamados tratados durante 14 dias com diferentes concentrações $(0 \%, 1 \%, 2 \%$ e $4 \%)$ de sementes de $S$. occidentalis, na ração. Foram utilizados 10 animais por grupo. São apresentados as médias e os respectivos desvios padrões

Figura 13 - Peso médio (g), de ratos recém-desmamados tratados durante 14 dias com diferentes concentrações $(0 \%, 1 \%, 2 \%$ e $4 \%)$ de sementes de $S$. occidentalis, na ração e seu grupo peer-feeding (PF). Foram utilizados 10 animais por grupo. São apresentados as médias e os respectivos desvios padrão. 
Figura 14 - Peso semanal e total (g), de ratos recém-desmamados tratados durante 14 dias com diferentes concentrações (0\%, 1\%, 2\% e 4\%) de sementes de $S$. occidentalis, na ração e seu grupo peer-feeding (PF). Foram utilizados 10 animais por grupo. São apresentados as médias e os respectivos desvios padrões.

Figura 15 - Consumo médio de ração (em g) pelos ratos recém-desmamados tratados durante 28 dias com 0 e $4 \%$ de sementes de S. occidentalis, na ração. Foram utilizados 10 animais por grupo. São apresentados as médias e os respectivos desvios padrões.

Figura 16 - Peso médio (em g), de ratos recém-desmamados tratados durante 28 dias com 0 e $4 \%$ de sementes de $S$. occidentalis, na ração e seu grupo peer-feeding (PF). Foram utilizados 10 animais por grupo. São apresentados as médias e os respectivos desvios padrões

Figura 17 - Peso semanal e total (em g), de ratos recém-desmamados tratados durante 28 dias com 0 e $4 \%$ de sementes de sementes de S. occidentalis, na ração e seu grupo peer-feeding (PF). Foram utilizados 10 animais por grupo. São apresentados as médias e os respectivos desvios padrões.

Figura 18 - Valor médio do hematócrito - HCT (\%), concentração de hemoglobina - HGB ( $\mathrm{g} / \mathrm{dL})$, do volume corpuscular médio - VCM $\left(\mu^{3}\right)$, hemoglobina corpuscular média - HCM $(\mu \mu \mathrm{g})$ e de leucócitos $\left(\times 10^{6} / \mathrm{mm}^{3}\right)$ de ratos recém-desmamados tratados durante 28 dias com 0 e $4 \%$ de sementes de $S$. occidentalis, na ração e seu grupo peer-feeding (PF). Foram utilizados 10 animais por grupo. São apresentados as médias e os respectivos desvios padrões.

Figura 19 - Peso relativo do baço (g/ 100g pv), de ratos recém-desmamados tratados durante 28 dias com 0 e $4 \%$ de sementes de S. occidentalis, na ração e seu grupo peer-feeding (PF). Foram utilizados 10 animais por grupo. São apresentados as médias e os respectivos desvios padrões.

Figura 20 - Celularidade da medula óssea (x $\left.10^{6} / \mathrm{cel}\right)$, de ratos recémdesmamados tratados durante 28 dias com 0 e $4 \%$ de sementes de S. occidentalis, na ração e seu grupo peer-feeding (PF). Foram utilizados 10 animais por grupo. São apresentados as médias e os respectivos desvios padrões. 
Figura 21 - Fotomicrográfia do baço de ratos recém-desmamados tratados durante 14 dias com sementes de $\mathbf{S}$. occidentalis na ração. $\mathbf{A}$. Integridade do parênquima esplênico com linfonodos bem delimitados, animal controle. B. Aumento do tamanho dos folículos linfóides e presença de megacariócitos (M), nos ratos do grupo 123 So4\% (seta). C. Megacariócitos (M) visíveis com núcleo multilobulado e nucléolos proeminentes (seta), nos ratos do grupo So4\%. D. Progenitores eritróides em diferentes estágios de maturação (seta) nos ratos do grupo So4\%. (H.E. 40x).

Figura 22 - Peso médio (em g), de ratos recém-desmamados tratados durante 28 dias com 0 e $4 \%$ de sementes de $S$. occidentalis, na ração e seu grupo peer-feeding (PF). Foram utilizados 10 animais por grupo. São apresentados as médias e os respectivos desvios padrões......

Figura 23 - Peso semanal e total (em g), de ratos recém-desmamados tratados durante 28 dias com 0 e $4 \%$ de sementes de sementes de $S$. occidentalis, na ração e seu grupo peer-feeding (PF). Foram utilizados 10 animais por grupo. São apresentados as médias e os respectivos desvios padrões.

Figura 24 - Avaliação do burst oxidativo e da fagocitose de neutrófilos, de ratos recém-desmamados tratados durante 28 dias com 0 e $4 \%$ de sementes de sementes de $S$. occidentalis, na ração e seu grupo peer-feeding (PF). Foram utilizados 10 animais por grupo. São apresentados as médias e os respectivos desvios padrões

Figura 25 - Consumo médio e total de ração $(\mathrm{g})$ pelas ratas tratadas do $6^{\circ}$ ao $20^{\circ}$ dias de gestação com diferentes concentrações $(0 \%, 1 \%, 2 \%$ e $4 \%$ ) de sementes de $S$. occidentalis, na ração. Foram utilizados 8 animais por grupo. São apresentados as médias e os respectivos desvios padrões.

Figura 26 - Peso relativo do baço $(\mathrm{g} / 100 \mathrm{~g} \mathrm{pv})$, de ratas tratadas do $6^{\circ}$ ao $20^{\circ}$ dias de gestação com diferentes concentrações $(0 \%, 1 \%, 2 \%$ e $4 \%)$ de sementes de $S$. occidentalis, na ração e seu grupo peerfeeding. Foram utilizados 8 animais por grupo. São apresentados as médias e os respectivos desvios padrões.

Figura 27 - Celularidade do baço $\left(\times 10^{6} / \mathrm{cel}\right)$, de ratas tratadas do $6^{\circ}$ ao $20^{\circ}$ dias de gestação com diferentes concentrações $(0 \%, 1 \%, 2 \%$ e $4 \%)$ de sementes de S. occidentalis, na ração e seu grupo peerfeeding (PF). Foram utilizados 8 animais por grupo. São apresentados as médias e os respectivos desvios padrões. 
Figura 28 - Valor do volume corpuscular médio - VCM $\left(\mu^{3}\right)$, hemoglobina corpuscular média - HCM $(\mu \mu \mathrm{g})$ e concentração de hemoglobina corpuscular média - $\mathrm{CHCM}(\%)$, da prole de ratas tratadas com $0 \mathrm{e}$ $4 \%$ de sementes de $S$. occidentalis na ração e seu grupo peerfeeding (PF). Foram utilizados 10 animais por grupo. São apresentados as médias e os respectivos desvios padrões.

Figura 29 - Fotomicrográfia do baço de ratos recém-desmamados tratados durante 14 dias com sementes de $S$. occidentalis na ração. A. Integridade do parênquima esplênico com linfonodos bem delimitados, animal controle. B. Aumento do tamanho dos folículos linfóides e presença de megacariócitos (M), nos ratos do grupo So4\% (seta). C. Megacariócitos (M) visíveis com núcleo multilobulado e nucléolos proeminentes (seta), nos ratos do grupo So4\%. D. Progenitores eritróides em diferentes estágios de maturação (seta) nos ratos do grupo So4\%. (H.E. 40x).

Figura 30 - Avaliação do burst oxidativo e da fagocitose de neutrófilos, de ratos machos, da prole de ratas tratadas com 0 e $4 \%$ de sementes de S. occidentalis na ração e seu grupo peer-feeding (PF). Foram utilizados 10 animais por grupo. São apresentados as médias e os respectivos desvios padrões.

Figura 31 - Avaliação do burst oxidativo e da fagocitose de neutrófilos, de ratas fêmeas, da prole de ratas tratadas com 0 e $4 \%$ de sementes de S. occidentalis na ração e seu grupo peer-feeding (PF). Foram utilizados 10 animais por grupo. São apresentados as médias e os respectivos desvios padrões. 


\section{SUMÁRIO}

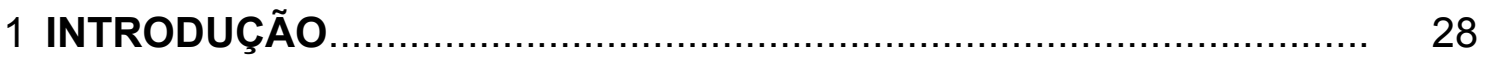

1.1 SOBRE O USO DE PLANTAS MEDICINAIS E FITOTERÁPICOS........... 29

1.2 SOBRE AS PLANTAS TÓXICAS ……………………..................... 33

1.3 SOBRE A AÇÃO DE XENOBIÓTICOS SOBRE O SISTEMA HEMATOPOÉTICO E ÓRGÃOS LINFÓIDES....................................... 28

1.4 SOBRE OS DADOS OBTIDOS NA DISSERTAÇÃO DE MESTRADO..... 43

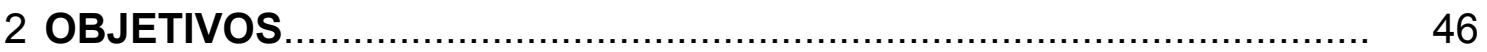

2.2 OBJETIVOS ESPECÍFICOS........................................................... 47

3 MATERIAL E MÉTODOS .......................................................... 51

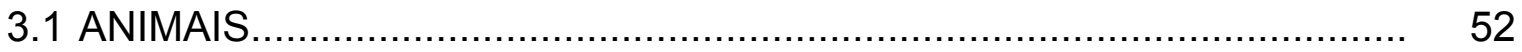

3.1.1 Avaliação do sistema imune e hematopoiético................................ 52

3.1.2 Estudo da toxicologia reprodutiva.............................................. 53

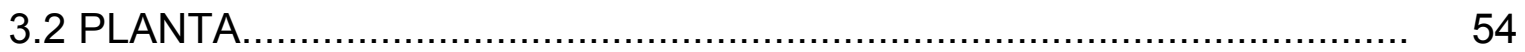

3.3 REAGENTES E SOLUÇÕES ........................................................... 54

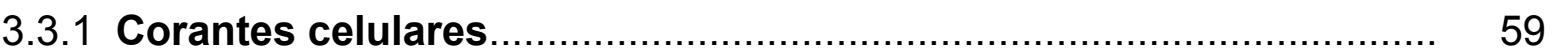

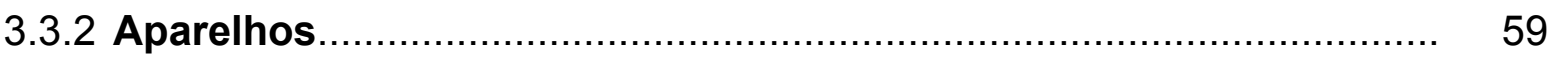

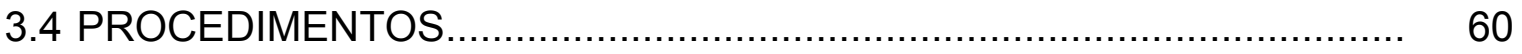

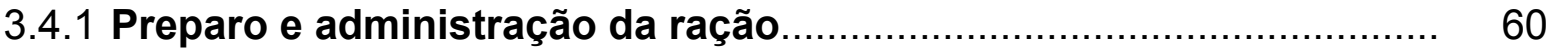

3.4.1.2 Administração de ração para ratos recém-desmamados......................... 60

3.4.1.3 Administração de ração ao grupo peer-feeding..................................... 61

3.4.2 Avaliação do consumo de ração e água, ganho de peso e observações clínicas.................................................................. 62

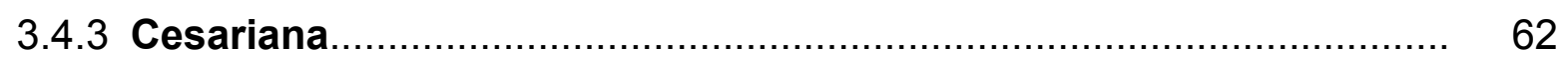

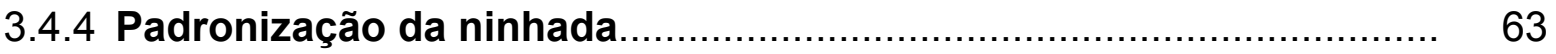

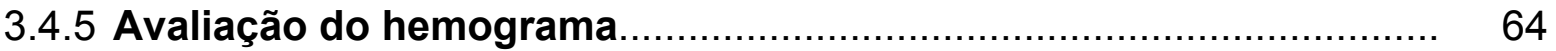

3.4.6 Avaliação do burst oxidativo e da fagocitose de neutrófilos por citometria de fluxo. 
3.4.7 Avaliação da resposta imune celular por meio da reação de hipersensibilidade do tipo tardia - Delayed Type Hypersensitivity test (DTH)

3.4.8 Avaliação da celularidade do baço e medula óssea............................ 68

3.4.9 Estudo Anátomo e Histopatológico................................................ 69

3.4.9.1 Microscopia óptica........................................................................ 69

3.5 DELINEAMENTO EXPERIMENTAL.......................................... 70

3.5.1 Experimento 1: Avaliação do sistema imune e hematopoético, de ratos recém-desmamados, tratados com diferentes concentrações de Senna occidentalis na ração.

3.5.1.1 Experimento 1.1: Avaliação hematológica

3.5.1.2 Experimento 1.2: Avaliação do burst oxidativo e da fagocitose de neutrófilos por citometria de fluxo, de ratos recém-desmamados, tratados com diferentes concentrações de Senna occidentalis na ração

3.5.1.3 Experimento 1.3: Avaliação da resposta imune celular por meio da reação de hipersensibilidade do tipo tardia (DTH), de ratos recémdesmamados, tratados com diferentes concentrações de Senna occidentalis na ração.

3.5.2 Experimento 2: Efeitos da administração prolongada das sementes de Senna occidentalis, em ratas durante o período de gestação

3.5.2.1 Experimento 2.1: Avaliação do sistema imune e hematopoético, na prole de ratas tratadas com 0 e $4 \%$ de sementes de Senna occidentalis na ração e seu grupo peer-feeding.

3.5.2.1.1 Experimento 2.1.1: Avaliação hematológica.

3.5.2.1.2 Experimento 2.1.2: Avaliação do burst oxidativo e da fagocitose de neutrófilos e de macrófagos por citometria de fluxo.

3.5.2.1.3 Experimento 2.1.3: Avaliação da resposta imune celular por meio da reação de hipersensibilidade do tipo tardia - Delayed Type Hypersensitivity test (DTH).

3.6 ANÁLISE ESTATÍSTICA............................................................... 75

4 RESULTADOS.. 
4.1 EXPERIMENTO 1: AVALIAÇÃO DO SISTEMA IMUNE E HEMATOPOÉTICO, DE RATOS RECÉM-DESMAMADOS, TRATADOS COM DIFERENTES CONCENTRAÇÕES DE Senna occidentalis NA RAÇÃO DURANTE 14 DIAS.

4.2 EXPERIMENTO 2: AVALIAÇÃO DO BURST OXIDATIVO E DA FAGOCITOSE DE NEUTRÓFILOS POR CITOMETRIA DE FLUXO, DE RATOS RECÉM-DESMAMADOS, TRATADOS COM DIFERENTES CONCENTRAÇÕES DE Senna occidentalis NA RAÇÃO.

4.3 EXPERIMENTO 3: AVALIAÇÃO DA HIPERSENSIBILIDADE DO TIPO TARDIA A SORO ALBUMINA BOVINA (BSA), DE RATOS RECÉMDESMAMADOS TRATADOS COM DIFERENTES CONCENTRAÇÕES DE SEMENTES DE Senna occidentalis NA RAÇÃO DURANTE 14 DIAS.

4.4 EXPERIMENTO 4: AVALIAÇÃO DO SISTEMA IMUNE E HEMATOPOÉTICO, DE RATOS EM CRESCIMENTO, TRATADOS COM 0 E 4\% DE SEMENTES DE Senna occidentalis NA RAÇÃO DURANTE 28 DIAS E SEU GRUPO PEER-FEEDING.

4.5 EXPERIMENTO 5: AVALIAÇÃO DO BURST OXIDATIVO E DA FAGOCITOSE DE NEUTRÓFILOS POR CITOMETRIA DE FLUXO, DE RATOS EM CRESCIMENTO, TRATADOS COM 0 E $4 \%$ DE SEMENTES DE Senna occidentalis NA RAÇÃO DURANTE 28 DIAS E SEU GRUPO PEER-FEEDING.

4.6 EXPERIMENTO 6: EFEITOS DA ADMINISTRAÇÃO DAS DIFERENTES CONCENTRAÇÕES DE SEMENTES DE Senna occidentalis NA RAÇÃO DE RATAS TRATADAS DO $6^{\circ}$ AO $20^{\circ}$ DIA DE GESTAÇÃO.

4.7 EXPERIMENTO 7: AVALIAÇÃO DO SISTEMA IMUNE E HEMATOPOÉTICO, NA PROLE DE RATAS TRATADAS COM 0 E 4\% DE SEMENTES DE Senna occidentalis NA RAÇÃO E SEU GRUPO PEER-FEEDING 
4.7.1 Experimento 7.1: Avaliação hematológica na prole de ratas tratadas com 0 e $4 \%$ de sementes de Senna occidentalis na ração e seu grupo peer-feeding

4.7.2 Experimento 7.2: Avaliação do burst oxidativo e da fagocitose de neutrófilos por citometria de fluxo na prole de ratas tratadas com 0 e $4 \%$ de sementes de Senna occidentalis na ração e seu grupo peer-feeding.

4.7.3 EXPERIMENTO 7.3: Avaliação da hipersensibilidade do tipo tardia a soro albumina bovina (BSA), na prole de ratas tratadas com 0 e 4\% de sementes de Senna occidentalis na ração e seu grupo peer-feeding

5 DISCUSSÃO

6 CONCLUSÕES 198 REFERÊNCIAS 
Introdução 28

1 INTRODUÇÃO 


\section{INTRODUÇÃO}

\subsection{SOBRE O USO DE PLANTAS MEDICINAIS E FITOTERÁPICOS}

O uso de plantas para fins medicinais e no tratamento de doenças remonta aos primórdios da humanidade (CRAGG; NEWMAN, 2001). Portanto, é fato que as plantas medicinais possuem papel chave dentro da saúde pública. A Organização Mundial de Saúde - OMS (2000) reconhece que $80 \%$ da população em países em desenvolvimento, ainda recorrem ao uso de plantas medicinais, dentro do sistema de atenção primária da saúde, devido a alguns fatores como a pobreza e a falta de acesso à medicina tradicional.

No Brasil, a utilização de plantas com fins medicinais é uma prática muito difundida, enriquecida pelo costume comum proveniente dos índios, negros e europeus. A miscigenação destas raças e povos, associada à grande diversidade vegetal do país, conduziu o uso de uma medicina tradicional baseada em diferentes plantas e métodos de tratamento (BRANDÃO, 1996; BARRETO et al., 2006). Devese ainda considerar que as plantas medicinais representam uma opção barata, por não requerer uma área muito grande nem depender de custos elevados para a sua implantação, tornando o cultivo destas uma prática comum em quintais urbanos ou em áreas da zona rural (LIMA, 2000).

Além do uso de plantas medicinais, os fitoterápicos também vêm sendo amplamente empregados no nosso país. Medicamento fitoterápico, segundo a 
definição da Agência Nacional de Vigilância Sanitária - ANVISA (2004) é aquele medicamento obtido empregando-se exclusivamente matérias-primas ativas vegetais. Apresenta como características o fato de se conhecer a eficácia e os riscos de seu uso, assim como a reprodutibilidade e constância de sua qualidade. Sua eficácia e segurança devem ser validadas por meio de levantamentos etnofarmacológicos de utilização, documentações técnicas e científicas em publicações ou ensaios clínicos de fase 3 que é a fase de ensaio piloto, na qual o medicamento será administrado a um grande número de pacientes, para avaliar a eficácia e segurança do produto (FERREIRA, 2002).

Potencialmente, todas as partes da planta são utilizadas para fins terapêuticos (raízes, rizomas, caule, casca, folhas, flores, frutos e sementes), por meio de diferentes formas de preparo (chás e infusões, decocções, tinturas, xaropes, óleos, unguentos e pomadas, compressas, duchas, resinas, pó, goma e outros) e administrados através de distintas vias de administração (oral, inalatória, dérmica, vaginal e retal) (HALBERSTEIN, 2005).

De fato, várias plantas medicinais apresentam propriedades bioativas com efeitos fisiológicos, potencial terapêutico e de cura, confirmado por meio de repetidos ensaios pré - clínicos de biodisponibilidade e análises laboratoriais. Neste contexto, a Relação Nacional de Plantas Medicinais de Interesse ao Sistema Único de Saúde (RENISUS) apresenta, até o momento, 71 plantas medicinais, com potencial para gerar produtos de interesse ao Sistema Único de Saúde - SUS. A finalidade desta lista é a de orientar estudos e pesquisas que possam subsidiar a elaboração da relação de fitoterápicos disponíveis para uso da população, com segurança e eficácia para o tratamento de determinada doença. Assim, como exemplos, citam-se: o cajueiro (Anacardium occidentale), o maracujá-doce (Passiflora alata), a calêndula 
(Calendula officinalis), a jurubeba-verdadeira (Solanum paniculatum), o gengibre (Zingiber officinale), a hortelã (Mentha piperita), a arruda (Ruta graveolens), dentre outros (RENISUS, 2009).

Se, por um lado, o uso de plantas medicinais e fitoterápicos permite o acesso ao tratamento das faixas mais carentes da população e, portanto, de certa maneira, a inclusão social, a idéia de que estas substâncias são seguras e livres de efeitos colaterais é totalmente falsa. Neste sentido, é amplamente conhecido que um grande número de constituintes tóxicos poderá estar presente em plantas medicinais ou utilizadas para a produção do fitoterápico (CALIXTO, 2000; ENGLER et al., 2009). De fato, a utilização e a aplicação dos potenciais botânicos e os possíveis efeitos colaterais das plantas medicinais, devem ser investigados de forma intensa, por diferentes metodologias. Estas investigações abrangem desde dados etnobotânicos, entrevistas com a população, coleta do espécime, ensaios préclínicos e clínicos duplo-cego, análises bioquímicas e métodos mais específicos como a cromatografia líquida de alta eficiência - CLAE ou HPLC (HALBERSTEIN, 2005).

Entretanto, o empenho da comunidade cientifica em assegurar a eficácia e o uso seguro das plantas medicinais vai ao encontro do apelo que as mesmas exercem sobrea população, uma vez que o conhecimento e uso destas são baseados nos costumes e tradições locais (ACCORSI, 2000; ARNOUS et al., 2005). Assim, por meio, do levantamentode plantas medicinais utilizadas no MunicípiodelpênoRioGrande do Sul, Ritter et al. (2002), constataramquemuitas das plantasas quais os moradoresfazemuso apresentam toxicidade estabelecida, porém tal fato não era de conhecimento dos usuários. Além disso, o controle da comercialização pelos órgãos oficiais em feiras 
livres, mercados públicos ou lojas de produtos naturais no Brasil ainda é incipiente (ARNOUS et al., 2005).

Neste sentido, espécies vegetais, cujo uso pode ser atribuído ao modismo, são freqüentemente citadas em levantamentos realizados junto ao comércio de raizeiros, principalmente aquelas utilizadas para emagrecimento, como: chapéu-decouro (Echinodorus macrophyllus), porangaba (Clavija nutans), carqueja (Baccharis trimera) e as várias espécies de sena (Cassia occidentalis, C. auriculata, C.angustifolia, C. caroliniana, C. ciliata, C. falcata, C. foetida, C. frutescens, C. geminiflora, C. linearis, C. longisiliqua, C. obliquifolia, C. planisiliqua, C. sophera, Ditremexa occidentalis) (NUNES et al., 2003; MARTINAZZO; MARTINS, 2006).

Particularmente no que se refere à sena, esta é a planta mais lembrada, não só pelos "raizeiros" como pela população, devido as suas propriedades laxantes e emagrecedoras. No estudo conduzido por Martinazzo e Martins (2006), sobre as principais plantas utilizadas pela população de Cascavel/ $P R$, foi verificado que $98 \%$ dos entrevistados utilizam as folhas desta planta como laxante. De fato, os antranóides presentes na planta são comumente empregados popularmente como medicamento para constipação crônica (SEYBOLD et al. 2004; GERLACK; MORRONE, 2006; SOYUNCU; CETE; NOKAY, 2008).

Além disso, outras finalidades terapêuticas são atribuídas ao uso da S. occidentalis, tais como expectorante, agente antibacteriano, antiinflamatório e antiplaquetário, vermífugo e para o tratamento de doenças hepáticas (CHOPRA et al., 1980; ADAM et al., 2001; NADAL et al., 2003; SOYUNCU; CETE; NOKAY, 2008).

Embora a S.occidentalis venha sendo amplamente utilizada pela população, que acredita que, por ser "natural" não promove efeitos adversos ou tóxicos, 
trabalhos distintos, de diferentes autores, vêm mostrando que o uso prolongado desta planta no ser humano pode causar desconforto abdominal, perda de eletrólitos e água (SOYUNCU; CETE; NOKAY, 2008), paralisia do íleo (SOSSAI; NASONE; CANTALAMESSA, 2007) e hepatotoxicidade (VASHISHTHA et al., 2007), além de causar riscos para mulheres grávidas por estimular a motilidade uterina e provocar aborto (VEIGA JR. et al., 2005), o que a torna, indubitavelmente, um problema de saúde pública.

\subsection{SOBRE AS PLANTAS TÓXICAS}

Pode-se definir como planta tóxica de interesse pecuário aquela que, quando ingerida pelos animais domésticos, sob condições naturais, causa danos à saúde ou mesmo a morte. Ainda, para que a planta seja considerada tóxica, está deverá ter sua toxicidade comprovada experimentalmente (TOKARNIA et al., 2000).

Pode-se definir como planta tóxica de interesse pecuário aquela que, quando ingerida pelos animais domésticos, sob condições naturais, causa danos à saúde ou mesmo a morte. Ainda, para que a planta seja considerada tóxica, deverá ter sua toxicidade comprovada experimentalmente (TOKARNIA et al., 2000).

No Brasil, devido à carência de dados sobre a freqüência das causas de mortalidade regionais, é difícil estimar as perdas por morte dos animais ocasionadas pelas plantas tóxicas. Segundo Riet-Correa e Medeiros (2001), no Rio Grande do Sul e Santa Catarina a mortalidade anual de bovinos é de $5 \%$ causada por plantas tóxicas. As perdas econômicas ocasionadas pelas plantas tóxicas podem ser diretas e indiretas. São consideradas perdas diretas, aquelas caracterizadas pela queda nos 
índices reprodutivos, redução da produtividade nos animais sobreviventes, alterações transitórias, enfermidades subclínicas e óbitos. Em relação às perdas econômicas indiretas, estas compreendem os custos gerados devido às medidas de profilaxia, controle e tratamento dos animais. Além disso, a ocorrência, freqüência e distribuição geográfica das plantas tóxicas contribuem para a epidemiologia da intoxicação animal, por diversos fatores como: palatabilidade, fome, sede, desconhecimento, acesso à fonte de intoxicação, dose tóxica, período de ingestão e variações da toxicidade (RIET-CORREA; MÉNDEZ; SCHILD, 1993; TOKARNIA et al., 2000).

A Senna occidentalis (L) Link - S. occidentalis (Figura 1), sinônimo Cassia occidentalis, é uma planta herbácea, anual, pertencente à família Leguminosae Caesalpinoideae (TOKARNIA et al., 2000), amplamente distribuída em regiões tropicais e subtropicais do mundo (ROGERS et al., 1979; MARTIN et al., 1981; GRAZIANO et al., 1983; COLVIN et al., 1986; BARROS et al., 1990; RODRIGUES et al., 1993; VASHISHTHA et al., 2007).

Apesar da ampla distribuição da S. occidentalis pelo Brasil, é na região Sul do país que esta planta tem causado problemas de intoxicação com maior freqüência (TOKARNIA et al., 2000; RIET-CORREA; MEDEIROS, 2001). Este vegetal é muito comum em pastagens, beira de estradas, terrenos baldios e culturas anuais como, por exemplo, de milho, do sorgo e da soja (LORENZI, 1991; PERGO et al., 2008). A S. occidentalis possui vários nomes vulgares, tais como "fedegoso", "mata-pasto", "verdadeiro", "mamangá", "sene", "cigarreira", "lava-pratos", entre outros (HOEHNE, 1939; JOLY, 1977). 


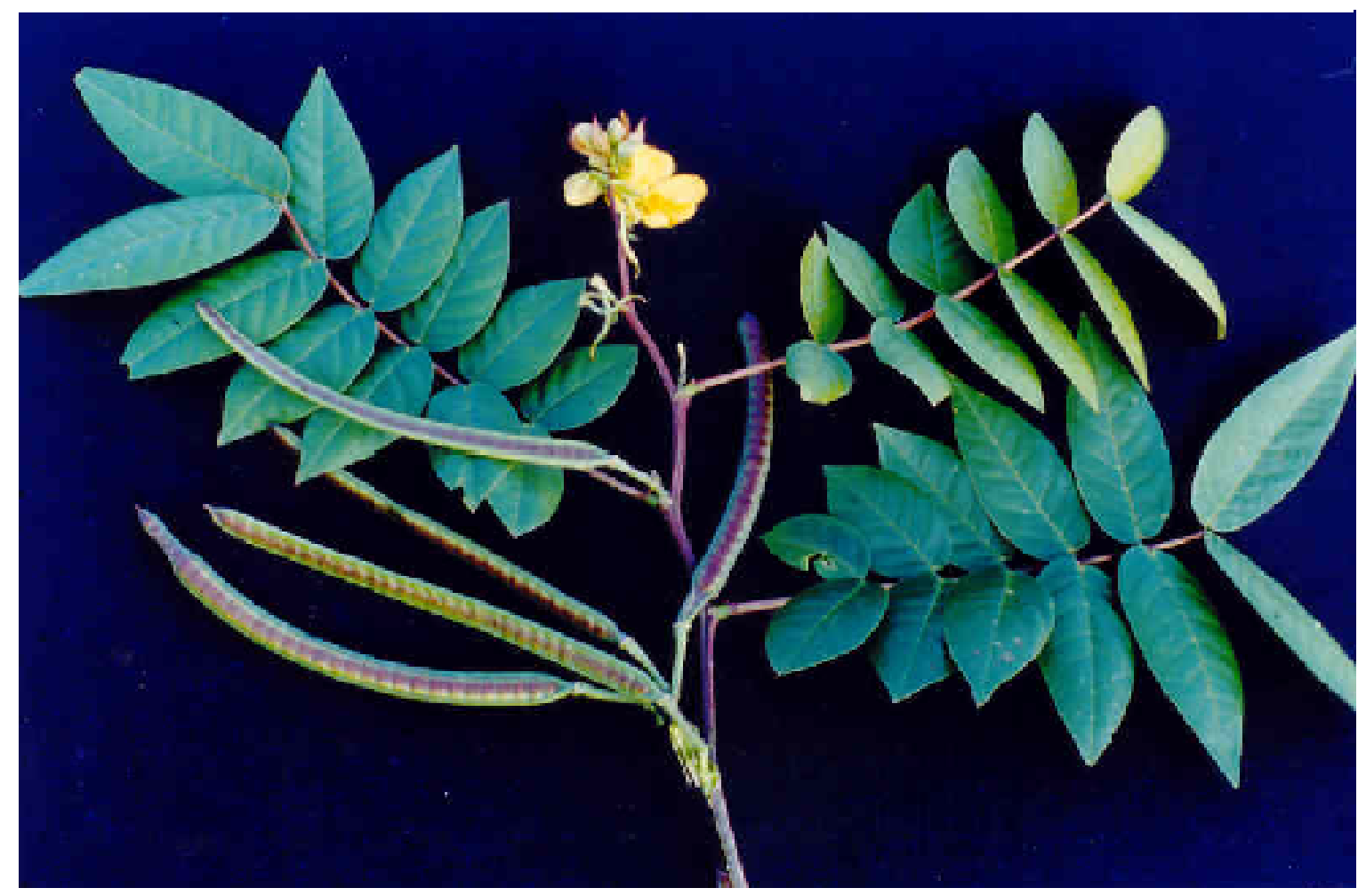

Fonte: KISSMANN, K. G; GROTH, D. Plantas infestantes e nocivas, tomo II, BASF, 1995

Figura 1 - Senna occidentalis

De acordo com Lorenzi (1991, p. 265),

[...] a S. occidentalis é uma planta perene, subarbustiva, lenhosa, ramificada, medindo de 1-2 metros de altura, com reprodução por sementes. As folhas são alternadas, compostas parapinadas, com 46 pares de folíolos glabros de 6-7 cm de comprimento. As inflorescências são axilares e terminais, em racemos com poucas flores pediceladas e de coloração amarelo ouro. Os frutos são formados dentro de vagens achatadas, mais ou menos retas, de coloração marrom, com 10-14 cm de comprimento. Esta leguminosa floresce no período de setembro a outubro e frutifica no período de fevereiro a abril. Poderá ser diferenciada das outras espécies de Senna através das características no direcionamento de crescimento das vagens, ou seja, no caso da Senna occidentalis, este ocorre de forma curva, com as pontas para cima; estas vagens, quando imaturas, são verdes, com faixas transversais marrons, tornando-se secas no outono, quando as sementes estão maduras. 
A S. occidentalis cresce agregada a plantações de cereais e, além de competir com nutrientes úteis a essas culturas, pode contaminá-las com suas sementes durante a coleta mecânica (DOLLAHITE; HENSON, 1965). Caso não haja uma separação adequada dos tipos de sementes, principalmente por meio de peneiragem, separação por densidade ou ambas, as sementes de $S$. occidentalis poderão vir a compor parte do produto final destinado à alimentação humana ou animal, levando a um desbalanço nutricional e causando ainda o risco de se incluir nesta dieta algum componente tóxico (BARROS, 1991; AFONSO; POTT, 2002). Contudo, foi somente com o desenvolvimento da pecuária e a ocorrência de importantes surtos de intoxicação em países onde a prevalência desta planta é alta, como no Sul dos Estados Unidos da América, França, Austrália e Brasil (BAILEY, 1977), é que se iniciaram estudos mais aprofundados sobre os efeitos tóxicos da S. occidentalis (TASAKA, 2000; AFONSO; POTT, 2002).

As espécies animais mais acometidas pela $S$. occidentalis são os bovinos (BARROS et al., 1999), suínos (TIMM; RIET-CORREA; 1997), eqüinos (BARROS et al., 1990) e aves (NAKAGE et al., 2000), por serem animais frequentemente criados de maneira extensiva.

Nas intoxicações sejam elas naturais ou experimentais, os animais podem apresentar sinais clínicos por vezes semelhantes, porém, a intensidade das manifestações clínicas pode variar entre as espécies estudadas (TASAKA, 2000; WEG, 2001; BARBOSA-FERREIRA et al., 2005; HUEZA et al., 2007). Desta forma, de maneira geral, os animais intoxicados com concentrações moderadas ou elevadas (de $3 \%$ a $20 \%$ ) de sementes de S. occidentalis apresentam abatimento, diarréia, fraqueza muscular, incoordenação motora, tremores musculares, relutância em mover-se, períodos de decúbito esternal, decúbito lateral e morte 
(TOKARNIA et al., 2000). Por outro lado, em intoxicação prolongada, com baixas concentrações de sementes da planta (de 0,1 a 1\%), pode se verificar como sinal clínico apenas anorexia e queda no ganho de peso (CALORE et al., 1997; HARAGUCHI et al., 1998).

Em relação aos achados na necropsia e histopatológicos, nas diferentes espécies animais, verificam-se como principais lesões as degenerações do músculo esquelético e cardíaco (O’HARA; PIERCE, 1974a,b; HERBERT et al., 1983; ROGERS et al., 1979; CAVALIERI et al., 1997). Pode-se também observar alterações hepáticas (MERCER et al., 1967; TASAKA et al., 2000), renais (ELSAYED, 1993; BARROS et al., 1999). Ainda, um estudo recente, conduzido neste laboratório (BARBOSA-FERREIRA et al., 2005), mostrou que a administração prolongada de baixas doses da $S$. occidentalis produz alterações no sistema nervoso central.

Por outro lado, deve-se considerar que dependendo da espécie animal, a gravidade e/ou localização das lesões pode variar. Desta maneira, a miopatia degenerativa da musculatura esquelética e cardíaca prevalece na espécie bovina e suína (MERCER et al., 1967; RODRIGUES et al., 1993), enquanto que em leporinos foi observada lesão mais severa na musculatura cardíaca (TASAKA et al., 2000).

O diagnóstico das intoxicações por S. occidentalis deve ser baseado nos dados clínicos e epidemiológicos, nos achados de necropsia e na histopatologia. A fonte da planta tóxica, nas pastagens ou como sementes contaminando grãos usados na ração dos animais, deve ser pesquisada e confirmada (RIET-CORREA et al., 1993).

O princípio ativo tóxico da S. occidentalis foi identificado como sendo uma antraquinona, a diantrona (HARAGUCHI et al., 1996). No entanto, foram extraídas 
de várias espécies de Senna, inclusive da $S$. occidentalis, outras substâncias potencialmente tóxicas como: flavonóides, oxalato de cálcio, albumina tóxica, glicosídeos esteróides, glicosídeos saponínicos, glicosídeos antraquinônicos, senosídeos A, B, C e D, emodina, aloe-emodina, reína e crisofanol e $\mathrm{N}$ metilmorfolina (KIM et al., 1971; BOTSARIS et al., 1995; MEDOUA; MBOFUNG, 2007; SOYUNCU; CETE; NOKAY, 2008).

Como proposto por Cavalieri et al. (1997), o mecanismo de ação tóxico da S. occidentalis estaria relacionado ao desacoplamento da fosforilação oxidativa mitocondrial, produzido pela diantrona; assim estes autores teorizaram que esta antraquinona agiria diretamente sobre o metabolismo desta organela.

\subsection{SOBRE A AÇÃO DE XENOBIÓTICOS SOBRE O SISTEMA HEMATOPOIÉTICO E ÓRGÃOS LINFÓIDES}

Métodos tradicionais para a avaliação toxicológica, como exames histológicos revelam, há muito tempo, que o sistema imune é alvo freqüente de acometimento por agentes ambientais, químicos, drogas de abuso ou radiação, após exposição aguda ou subcrônica (LUSTER et al., 1988). De fato, a complexidade do sistema imune resulta em múltiplos sítios alvos potenciais que dão origem aos efeitos patológicos imunotóxicos dos xenobióticos (DE JONG; VAN LOVEREN, 2007). Desta forma, estudos que avaliam a ação dos xenobióticos sobre o sistema imune para determinar o risco é de grande importância (MOTYKIEWICZ et al., 1998; DRELA, 2006; RIER, 2008). Com o objetivo de melhor se compreender os objetivos 
da presente pesquisa, será realizada, a seguir, uma breve revisão sobre a fisiologia do sistema imune.

Segundo Lawrence e Kim (2000), a produção de células que participam da defesa do organismo do hospedeiro, tanto de natureza inespecífica quanto especifica, é rigorosamente controlada em dois níveis: o central, que compreende os sítios hemato-linfopoéticos medulares e o periférico presente no baço, linfonodos e nos tecidos linfóides associados às mucosas.

Segundo Lawrence e Kim (2000), a produção de células que participam da defesa do organismo do hospedeiro, tanto de natureza inespecífica quanto especifica, é rigorosamente controlada em dois níveis: o central, que compreende os sítios hemato-linfopoéticos medulares e o periférico presente no baço, linfonodos e nos tecidos linfóides associados às mucosas.

As células envolvidas nas respostas imunes encontram-se organizadas em tecidos e órgãos, a fim de realizar suas funções de forma mais eficiente. Estas estruturas são, coletivamente, denominadas de sistema linfóide. O sistema linfóide é composto por linfócitos, células acessórias como os macrófagos e células apresentadoras de antígenos e, em alguns tecidos, células epiteliais. O tecido linfóide distribui-se pelo organismo como órgãos discretamente encapsulados ou como acúmulo de tecidos linfóide difuso (LYDYARD; GROSSI, 1999; WEST, 2002; BATISTA; HARWOOD, 2009).

Os órgãos linfóides primários são os principais sítios de desenvolvimento dos linfócitos no organismo e são constituídos pelo timo e a medula óssea. Neles, os linfócitos se diferenciam a partir de células-tronco linfóides, proliferam-se e amadurecem em células funcionais. Nos mamíferos, as células T amadurecem no timo, e as células B no fígado fetal e na medula óssea. As aves possuem um local 
especializado de geração de célula B que é a bursa de Fabricius (LAWRENCE; KIM, 2000; DIETERT, 2009).

No que tange ao timo, seu microambiente é influenciado por diferentes fatores intrínsecos e extrínsecos ao longo do desenvolvimento, incluindo: estados fisiológicos, condições fisiológicas, condições ambientais, doenças entre outros (DOMÍNGUEZ-GERPE; REY-MÉNDEZ, 2003; DRELA, 2006; FANG et al., 2008). Todas estas condições especiais, tornam o timo um órgão alvo para a ação de xenobióticos, que pode refletir na queda do desenvolvimento dos timócitos devido a exacerbação da apoptose, retardo na maturação dos timócitos, geração de células T reativas e na inibição ou estimulação na produção de células recentes que irão migrar para periferia (DRELA, 2006; FANG et al., 2008; RIER, 2008).

Por sua vez, as respostas imunes de natureza celular e humoral ocorrem nos tecidos linfóides secundários que é constituído pelo baço, os linfonodos e os tecidos linfóides associados às mucosas, incluindo as amídalas e as placas de Peyer no íleo, onde também são geradas as células efetoras de memória. O baço encarregase, predominantemente, dos antígenos que têm disseminação via sanguínea; os linfonodos elaboram respostas imunes contra antígenos circulantes na linfa, quer tenham sido absorvidos pela pele ou pelas vísceras internas. As tonsilas, as placas de Peyer e outros tecidos associados às mucosas respondem a antígenos que penetram as barreiras mucosas. As respostas imunes geradas nos órgãos linfóides secundários requerem macrófagos fagócitos, células apresentadoras de antígenos e células B e T maduras (KUBY, 1997; DESCOTES, 2005; FURZE; RANKIN, 2008).

Assim, pode-se supor que o comprometimento do sistema imune detectado pela redução da celularidade dos órgãos linfóides, alterações nas subpopulações de linfócitos, diminuição da resistência do hospedeiro e alterações nas funções da 
resposta imune específica e inespecífica, deve fazer parte daqueles protocolos de avaliação de toxicidade (BURNS-NASS et al., 2000; DESCOTES, 2005).

De fato, as áreas relacionadas à atividade imunomodulatória, no que tange ao estudo com plantas tóxicas, têm sido alvo recorrente de investigações devido ao seu potencial de modificar a resposta imune inespecífica e específica (AGARWAL et al., 1999; DE JONG; VAN LOVEREN, 2007).

Particularmente no que se refere à toxicidade promovida pela S. occidentalis, um estudo conduzido por Silva et al. (2003) mostrou redução nos diâmetros dos folículos e na densidade das regiões cortical e medular da bursa de Fabricius e redução da polpa branca do baço, em aves tratadas com até um $1 \%$ de tegumento externo (TE) da planta. Estes dados, avaliados em conjunto, sugerem um possível efeito da S. occidentalis sobre a resposta imunológica não-específica dos animais tratados com esta planta.

Outro aspecto que deve ser considerado na interação de xenobióticos com o organismo diz respeito às linhagens celulares precursoras da medula óssea e às células sangüíneas circulantes, as quais participam de funções críticas na defesa do hospedeiro (HARVEY, 1996; DRELA, 2006; CHURIN et al., 2008). Neste sentido, de acordo com Guest e Uetrecht (2000), os xenobióticos que causam toxicidade na medula óssea pertencem a um grupo heterogêneo de compostos que agem por meio de vários mecanismos; entretanto, a etiologia destas ações tóxicas é ainda pouco compreendida. Uma busca na literatura mostra que a hematotoxicidade é manifestada pela alteração do número de células maduras no sangue ou medula óssea, e pode ser expressa pela destruição excessiva ou supressão da produção destas células (LANNING, 1998; SHEN et al., 2005; CHURIN et al., 2008). 
Dentre os xenobióticos que causam supressão de células do tecido hematopoiético, destacam-se os agentes antineoplásicos como a ciclofosfamida e o busulfan (HOAGLAND, 1982; GALE, 1988; DE JONG; VAN LOVEREN, 2007). Entretanto, trabalhos têm demonstrado que alguns princípios ativos tóxicos de plantas podem também atuar de maneira deletéria sobre o tecido sangüíneo. Neste sentido, Pan et al. (1993) verificaram que o metabólito da monocrotalina, um alcalóide pirrolizidínico presente nas espécies de Crotalaria spp, promove o aumento de eritrócitos imaturos micronucleados na medula óssea e no sangue periférico de camundongos (SANDERSON; CLARK, 1993).

Especificamente em relação a plantas do gênero Senna, estudos conduzidos por Dugan e Gumbmann (1990) evidenciaram congestão e depleção na medula óssea de ratos tratados com $16 \%$ de Senna na ração e diminuição de linfócitos e neutrófilos circulantes. Em adição, Voss e Brennecke (1991) observaram, em animais tratados com esta mesma planta, aplasia mielóide com leucocitose e trombocitose periférica na medula óssea e anemia moderada seguida de neutropenia. Estes mesmos autores observaram, também, hiperplasia e presença de histiócitos em linfonodos periféricos de ratos tratados com a planta, mostrando, assim, a intrínseca relação entre os compartimentos centrais e periféricos do sistema linfóide.

Todavia, a forma mais comum de interação entre os hematotoxicantes no organismo ocorre, de maneira indireta, por interferências na farmacocinética e farmacodinâmica (KRISHNAN; PELEKIS, 1995; RICH; HALL; 2005). Assim, muitos são os trabalhos que demonstram as perturbações causadas pelos xenobióticos em órgãos e sistemas, evocando respostas compensatórias do sistema hematopoiético. Neste contexto, a administração do extrato metanólico de "olho de gato" (Caesalpinia 
bonducella) e de "unha de vaca" (Bauhinia racemosa), a camundongos tratados 2 vezes ao dia por 13 semanas, apontaram aumento na contagem de neutrófilos e a diminuição de linfócitos, devido às alterações causadas na função do sistema hepático e renal destes animais (KUMAR et al., 2005).

De maneira similar, o estudo conduzido por Konan et al. (2007), em ratas tratadas por 30 dias, com $1000 \mathrm{mg} / \mathrm{kg}$ de extrato bruto de caju (Anacardium occidentale), sugeriram que o aumento de neutrófilos circulantes, de modo dosedependente, ocorreu devido às administrações constantes do extrato, como uma resposta fisiológica contra os componentes não próprios do organismo.

Além disso, são vários os estudos que relatam a interação entre fitoterápicos e medicamentos no comprometimento de processos fisiológicos dependentes de células de origem hematopoiética (FUGH-BERMAN, 2000; HU et al., 2005). Neste sentido, pacientes que foram submetidos ao tratamento prolongado com varfarina, e que concomitantemente fizeram uso de fitoterápicos à base de salvia (Salvia miltiorrhiza) e alho (Allium sativum), apresentaram aumento no tempo de coagulação e sangramento. Por sua vez, o ginko (Ginko biloba), quando associado a varfarina ou ácido acetilsalicílico, aumenta o tempo de sangramento, e quando associado a diuréticos tiazídicos, leva ao aumento da pressão sanguínea (HU et al., 2005).

\subsection{SOBRE OS DADOS OBTIDOS NA DISSERTAÇÃO DE MESTRADO}

Com base em um estudo prévio realizado, neste mesmo laboratório, no qual Silva et al., (2003) verificaram os efeitos imunotóxicos da S. occidentalis em ave, procurou-se, em nossa Dissertação de Mestrado, verificar se as sementes de 
S. occidentalis poderiam também produzir efeitos tóxicos nos órgãos linfóides de mamíferos, utilizando, para tal, ratos como modelo experimental.

Assim, naquela Dissertação, as sementes de $S$. occidentalis foram administradas, durante 14 dias, a ratos Wistar, machos, adultos em diferentes concentrações de sementes desta planta na ração: 1\% (So1), 2\% (So2) e 4\%(So4). Os animais do grupo peer-feeding (PF) receberam, diariamente, a mesma quantidade de ração consumida pelos animais tratados com So4, porém isentas da planta. Foram avaliados os seguintes parâmetros: consumo de água e ração e ganho de peso, avaliação hematológica e bioquímica; além da histopatologia, morfometria e de ensaios preconizados para o estudo da resposta imunológica não específica (MARIANO-SOUZA, 2005).

Todos os ratos pertencentes aos diferentes grupos experimentais apresentaram diminuição no consumo de ração e água e no ganho de peso. A avaliação hematológica revelou anemia microcítica e hipocrômica nos animais que receberam $4 \%$ da planta. Além disso, todos os animais dos grupos So2 e So4 apresentaram depleção de células linfóides e redução da polpa branca do baço. Os ratos pertencentes ao grupo So4 apresentaram redução no peso relativo do timo e diminuição da região cortical e também no diâmetro dos folículos medulares deste órgão. Estes mesmos animais apresentaram diminuição da produção de água oxigenada e óxido nítrico. Em relação à resposta inflamatória, todos os animais dos grupos experimentais, apresentaram redução na evolução do edema inflamatório agudo e crônico. Assim, este estudo demonstrou que também em mamíferos, a S. occidentalis pode comprometer o sistema imunológico, haja vista as alterações encontradas no timo e baço dos ratos expostos à planta. Além disso, verificou-se que as sementes desta planta também promovem efeitos tóxicos sobre eritrócitos e 
alterações na resposta inflamatória. A inclusão do grupo PF permitiu verificar que os efeitos encontrados não foram devido às possíveis alterações nutricionais promovidas pela queda do consumo de alimento e sim relacionados ao efeito tóxico direto da S. occidentalis (MARIANO-SOUZA, 2005).

Portanto, a presente pesquisa tomou como ponto de partida os dados obtidos na Dissertação de Mestrado e visa agora verticalizar este estudo, procurando-se investigar os efeitos desta planta no sistema imune e hematopoiético de ratos em outra idade (animais jovens, recém-desmamados), comparando-se com os dados obtidos em animais adultos. É ainda objetivo desta tese, auxiliar no estabelecimento de um protocolo de imunotoxicidade e hematotoxicidade, utilizando-se ratos como a espécie animal de escolha para esses estudos. 
Objetivos 46

2 OBJETIVOS 


\section{OBJETIVOS}

Avaliar os possíveis efeitos tóxicos produzidos pela administração de sementes de Senna occidentalis incorporadas à ração, em diferentes concentrações sobre os parâmetros imunológicos e hematopoiéticos, de ratos jovens e da prole de fêmeas tratadas durante a gestação.

\subsection{OBJETIVOS ESPECÍFICOS}

- Avaliar os possíveis efeitos tóxicos da administração de sementes de S. occidentalis em diferentes concentrações, sobre o sistema imune e hematopoético, de ratos em crescimento.

- Avaliar os possíveis efeitos tóxicos da administração de sementes de S. occidentalis em diferentes concentrações, sobre a celularidade do baço e medula óssea de ratos em crescimento.

- Avaliar os possíveis efeitos tóxicos da administração de sementes de S. occidentalis em diferentes concentrações, sobre timo, baço, linfonodos, fígado e intestino de ratos em crescimento, por meio de estudos anatomopatológicos. 
- Avaliar os possíveis efeitos tóxicos da administração de sementes de S. occidentalis em diferentes concentrações, sobre o burst oxidativo por neutrófilos por citometria de fluxo, de ratos em crescimento.

- Avaliar os possíveis efeitos tóxicos da administração de sementes de S. occidentalis em diferentes concentrações, sobre a intensidade e porcentagem de fagocitose por neutrófilos, por citometria de fluxo, de ratos em crescimento.

- Avaliar os possíveis efeitos tóxicos da administração de sementes de S. occidentalis em diferentes concentrações, sobre a produção das espécies reativas de oxigênio de neutrófilos, por citometria de fluxo, de ratos em crescimento.

- Avaliar os possíveis efeitos tóxicos da administração de sementes de S. occidentalis em diferentes concentrações, sobre a resposta imune celular por meio da reação de hipersensibilidade do tipo tardia (DTH), de ratos em crescimento.

- Avaliar os possíveis efeitos tóxicos da administração de sementes de S. occidentalis em diferentes concentrações, sobre o sistema imune e hematopoético de ratas durante o período de gestação.

- Avaliar os possíveis efeitos tóxicos da administração de sementes de S. occidentalis em diferentes concentrações, sobre o hemograma de ratas durante o período de gestação.

- Avaliar os possíveis efeitos tóxicos da administração de sementes de S. occidentalis em diferentes concentrações, sobre a celularidade do baço e medula óssea de ratas durante o período de gestação. 
- Avaliar os possíveis efeitos tóxicos da administração de sementes de S. occidentalis em diferentes concentrações, sobre timo, baço, linfonodos, fígado e intestino de ratas durante o período de gestação, por meio de estudos anatomopatológicos.

- Avaliar os possíveis efeitos tóxicos na prole, de ratas tratadas com diferentes concentrações de sementes de $S$. occidentalis, sobre o sistema imune e hematopoético.

- Avaliar os possíveis efeitos tóxicos na prole, de ratas tratadas com diferentes concentrações de sementes de S. occidentalis, sobre o hemograma.

- Avaliar os possíveis efeitos tóxicos na prole, de ratas tratadas com diferentes concentrações de sementes de $S$. occidentalis, sobre a celularidade do baço e medula óssea.

- Avaliar os possíveis efeitos tóxicos na prole, de ratas tratadas com diferentes concentrações de sementes de $S$. occidentalis, sobre timo, baço, linfonodos, fígado e intestino, por meio de estudos anatomopatológicos.

- Avaliar os possíveis efeitos tóxicos na prole, de ratas tratadas com diferentes concentrações de sementes de $S$. occidentalis, sobre o burst oxidativo e da fagocitose por neutrófilos por citometria de fluxo.

- Avaliar os possíveis efeitos tóxicos na prole, de ratas tratadas com diferentes concentrações de sementes de $S$. occidentalis, sobre a produção das espécies reativas de oxigênio por neutrófilos, por citometria de fluxo. 
- Avaliar os possíveis efeitos tóxicos na prole, de ratas tratadas com diferentes concentrações de sementes de $S$. occidentalis, sobre a resposta imune celular por meio da reação de hipersensibilidade do tipo tardia (DTH). 
Material e Métodos 51

MATERIAL E MÉTODOS 


\section{MATERIAL E MÉTODOS}

Para a execução desta tese foram utilizados os seguintes materiais e métodos.

\subsection{ANIMAIS}

Para a execução desta tese foram utilizados os seguintes sujeitos experimentai.

\subsubsection{Avaliação do sistema imune e hematopoiético}

Foram utilizados 50 ratos Wistar, machos, recém-desmamados com 21 dias de idade e com peso inicial entre 65 a $70 \mathrm{~g}$, provenientes do biotério do Departamento de Patologia da Faculdade de Medicina Veterinária e Zootecnia, da Universidade de São Paulo (FMVZ/USP). Os animais foram alojados em gaiolas de polipropileno fosco com tampas metálicas, medindo $40 \times 50 \times 20 \mathrm{~cm}$. Todas as gaiolas foram mantidas em sala com temperatura ambiente aproximadamente constante $\left(21-24^{\circ} \mathrm{C}\right)$ e iluminação artificial em ciclo de claro-escuro de 12 horas, iniciando-se a fase clara às 7:00 horas. Água e ração foram fornecidas ad libitum durante todo o período de permanência dos animais no biotério. Estes animais foram utilizados em conformidade com as normas e procedimentos relativos ao uso de animais de 
Laboratório do Departamento de Patologia da FMVZ/USP, os quais são baseados naqueles descritos pelo Committee on Care and Use of Laboratory Animal Resources - National Research Council, EUA.

O protocolo para a realização deste estudo foi submetido à Comissão de Bioética da Faculdade de Medicina Veterinária e Zootecnia - USP (protocolo $\mathrm{n}^{\circ}$ 653/2005), sendo aprovado no dia 25 de Abril de 2005.

\subsubsection{Estudo da toxicologia reprodutiva}

Foram utilizadas ratas da linhagem Wistar, virgens, pesando cerca de $220 \mathrm{~g}$ no início dos experimentos, provenientes do biotério do Departamento de Patologia da Faculdade de Medicina Veterinária e Zootecnia da Universidade de São Paulo (FMVZ/USP) e machos da mesma linhagem para o acasalamento. Os animais receberam os mesmos cuidados, conforme os procedimentos descritos acima. Para o acasalamento machos e fêmeas foram colocados em gaiolas, sempre no final da tarde na proporção de 1:2, respectivamente. Este procedimento foi repetido até que o número desejado de ratas prenhes fosse alcançado. Na amanhã seguinte ao acasalamento, sempre no horário compreendido entre 7 e 9 horas, procedeu-se ao lavado vaginal e, ao se confirmar à presença de espermatozóides neste lavado, por meio de análise microscopia, conforme técnica descrita por Vickery e Bennet (1970) considerava-se, então, o dia zero da gestação. Constatada a prenhez, as fêmeas foram mantidas individualmente nestas mesmas gaiolas até o final de cada experimento. 


\subsection{PLANTA ${ }^{1}$}

Foram utilizadas sementes de Senna occidentalis provenientes do Instituto Biológico de São Paulo, coletadas entre fevereiro e março de 2004 e 2007. Após a coleta, as sementes foram alojadas em local seco, até o momento de serem moídas e adicionadas à ração.

\subsection{REAGENTES E SOLUÇÕES}

- Adjuvante Completo de Freud - FCA (Sigma®);

- Soro Albumina Bovina (BSA) - Fração V (Sigma®);

- Diacetato 2'7' Diclofluoresceína (DCFH-DA / Molecular Probes, Eugene. OR, USA): foi dissolvido $25 \mathrm{mM}$ de DCFH em $1,0 \mathrm{~mL}$ de etanol (Synth $®)$. Este reagente foi mantido em geladeira $\left(-20^{\circ} \mathrm{C}\right)$, e protegido da luz. No momento do uso $50 \mu \mathrm{L}$ da solução mãe foi adicionado em $4,1 \mathrm{~mL}$ de PBS;

- Solução de PBS - solução salina tamponada com fosfato. Solução estoque: foram dissolvidos $82,0 \mathrm{~g}$ de cloreto de sódio $\left(\right.$ Synth $\left.^{\circledR}\right), 26,79 \mathrm{~g}$ de fosfato de sódio dibásico $\left(\right.$ Synth $\left.^{\circledR}\right)$ e $4,14 \mathrm{~g}$ de fosfato de sódio monohidratado $\left(\right.$ Synth $^{\circledR}$ ) em $1.000 \mathrm{~mL}$ de água filtrada em Filtro Milli-Q plus ${ }^{\circledR}$. Esta solução foi filtrada e armazenada em frasco previamente identificado, sob refrigeração $\left(2-8^{\circ} \mathrm{C}\right)$. No momento do uso, esta solução foi diluída na proporção de 1:10 de água filtrada em Filtro Milli-Q plus ${ }^{\circledR}$, mantendo-se um pH em torno de 7,2 a 7,4;

\footnotetext{
${ }^{1}$ A Senna occidentalis foi depositada no herbário Maria Eneida Fidalgo no Instituto Botânico de São Paulo na forma de exsicata sobre o número SP-363817.
} 
- Solução de PBS glicosado - salina tamponada com fosfato e glicose.

- Solução A: foram dissolvidos $80,0 \mathrm{~g}$ de cloreto de sódio (Synth $\left.{ }^{\circledR}\right), 2,0 \mathrm{~g}$ de cloreto de potássio (Synth ${ }^{\circledR}$ ), 2,0g de fosfato de potássio (Synth ${ }^{\circledR}$ ) e $21,5 \mathrm{~g}$ de fosfato de sódio dibásico $\left(\operatorname{Synth}^{\circledR}\right)$ em $800,0 \mathrm{~mL}$ de água filtrada em Filtro MilliQ plus ${ }^{\circledR}$. A solução resultante foi armazenada, em frasco previamente identificado, sob refrigeração $\left(2-8^{\circ} \mathrm{C}\right)$;

- Solução B: foi dissolvido $1,3 \mathrm{~g}$ de cloreto de cálcio $\left(\right.$ Synth $\left.^{\circledR}\right)$ em 100,0mL de água filtrada em Filtro Milli-Q plus ${ }^{\circledR}$. A solução resultante foi armazenada, em frasco previamente identificado, sob refrigeração $\left(2-8^{\circ} \mathrm{C}\right)$;

- Solução C: foi dissolvido 2,1g de cloreto de magnésio $\left(\right.$ Synth $\left.^{\circledR}\right)$ em 100,0mL de água filtrada em Filtro Milli-Q plus ${ }^{\circledR}$. A solução resultante foi armazenada em frasco previamente identificado, sob refrigeração $\left(2-8^{\circ} \mathrm{C}\right)$;

- Solução de glicose a 10\%: foi dissolvido 10,0g de glicose (Sigma $\left.{ }^{\circledR}\right)$ em 100,0 $\mathrm{mL}$ de água filtrada em Filtro Milli-Q plus ${ }^{\circledR}$. A solução resultante foi armazenada em frasco previamente identificado, sob refrigeração $\left(2-8^{\circ} \mathrm{C}\right)$;

- No momento do uso foram diluídos $8,0 \mathrm{~mL}$ da solução $A, 1,0 \mathrm{~mL}$ da solução B, 1,0mL da solução $C, 1,0 \mathrm{~mL}$ da solução de glicose a $10 \%$, completando-se o volume para $100,0 \mathrm{~mL}$ com água destilada mantendo-se o $\mathrm{pH}$ em torno de 7,2 a 7,4

- Solução aquosa de etilenodiamino-tetracético-dissódico (EDTA) a 10\%: foi dissolvido 10,0g de EDTA $\left(\right.$ Synth $^{\circledR}$ ) em $1000 \mathrm{~mL}$ de PBS. A solução resultante foi armazenada em frasco previamente identificado. A proporção indicada para uso foi de $0,1 \mathrm{~mL}$ da solução para $1 \mathrm{~mL}$ de sangue;

- Solução aquosa de etilenodiamino-tetracético-dissódico (EDTA) a 3mM: foi dissolvido $1,12 \mathrm{~g}$ de EDTA $\left(\right.$ Synth $^{\circledR}$ ) em $1,000 \mathrm{~mL}$ de PBS, em seguida esta 
solução foi colocada em um Becker e permaneceu no agitador magnético por 5 minutos. A solução foi armazenada em frasco previamente identificado mantido sob refrigeração $\left(2-8^{\circ} \mathrm{C}\right)$;

- Solução de meio de cultura RPMI 1641 (Gibco $\left.{ }^{\circledR}\right)$ : foram diluídos em $1.000 \mathrm{~mL}$ de água filtrada em Filtro Milli-Q plus ${ }^{\circledR}, 10,39 \mathrm{~g}$ de RPMI 1641 (Gibco ${ }^{\circledR}$ ), 2,00g de bicarbonato de sódio $\left(\right.$ Synth $\left.^{\circledR}\right), 292,0 \mathrm{~g}$ de glutamina $\left(\right.$ Synth $\left.^{\circledR}\right), 5,20 \mathrm{~g}$ de hepes $\left(\mathrm{Gibco}^{\circledR}\right), 100,0 \mathrm{mg}$ de estreptomicina $\left(\right.$ Sigma $\left.^{\circledR}\right)$ e $60,0 \mathrm{mg}$ de penicilina $\left(\right.$ Sigma $\left.^{\circledR}\right)$. Todo este procedimento foi realizado em fluxo laminar e a solução resultante foi filtrada e armazenada em frasco previamente identificado e mantida sob refrigeração $\left(2-8^{\circ} \mathrm{C}\right)$. No momento do uso o pH desta solução foi ajustado para 7,8;

- Solução estoque de Miristato acetato forbol (PMA) (ICN Biomedicals $\left.{ }^{\circledR}\right)$ : foram dissolvidos 10,0mg de PMA em 1,0mL de dimetilsulfóxido (DMSO) $\left(\right.$ Gibco $\left.^{\circledR}\right)$. Todo o procedimento foi realizado em fluxo laminar. A solução resultante foi armazenada em frasco previamente identificado e mantida sob refrigeração $\left(0^{\circ} \mathrm{C}\right)$ até o momento do uso;

- Solução de metacarn para coleta dos órgãos linfóides: foram diluídos $60,0 \mathrm{~mL}$ de álcool metílico $96^{\circ} \mathrm{GL}$ (Dinâmica ${ }^{\circledR}$ ), 30,0mL de clorofórmio 99,5\% $\left(\right.$ Dinâmica ${ }^{\circledR}$ ) e 10,0mL de ácido acético glacial 99,5\% (Dinâmica ${ }^{\circledR}$ ). Após esta diluição a solução resultante foi armazenada em frasco previamente identificado e mantida em temperatura ambiente até o momento do uso;

- Solução de sulfeto de amônio a $25 \%$ : dissolveu-se $25,0 \mathrm{~g}$ de sulfeto de amônio (grau PA) (Synth®) e completou-se para 100,0mL de água destilada; em seguida esta solução foi filtrada e armazenada em frasco previamente identificado; 
- Solução Salina a 0,9\%: dissolveu-se 9,0g de cloreto de sódio ( $\mathrm{NaCl})$ (Synth®) e completou-se para $1.000 \mathrm{~mL}$ de água filtrada em Filtro Milli-Q plus ${ }^{\circledR}$, em seguida esta solução foi colocada em um Becker e permaneceu no agitador magnético por 5 minutos. A solução foi armazenada em frasco previamente identificado mantido sob refrigeração $\left(2-8^{\circ} \mathrm{C}\right)$;

- Solução Salina 0,2\%: dissolveu-se 2,0g de cloreto de sódio $(\mathrm{NaCl})($ Synth®) e completou-se para $1.000 \mathrm{~mL}$ de água filtrada em Filtro Milli-Q plus ${ }^{\circledR}$, em seguida esta solução foi colocada em um Becker e permaneceu no agitador magnético por 5 minutos. A solução foi armazenada em frasco previamente identificado mantido sob refrigeração $\left(2-8^{\circ} \mathrm{C}\right)$;

- Solução Salina 1,6\%: dissolveu-se $16.0 \mathrm{~g}$ de cloreto de sódio $(\mathrm{NaCl})$ (Synth®) e completou-se para $1.000 \mathrm{~mL}$ de água filtrada em Filtro Milli-Q plus ${ }^{\circledR}$, em seguida esta solução foi colocada em um Becker e permaneceu no agitador magnético por 5 minutos. A solução foi armazenada em frasco previamente identificado mantido sob refrigeração $\left(2-8^{\circ} \mathrm{C}\right)$;

- Solução Salina 0,85\%: dissolveu-se $85,0 \mathrm{~g}$ de cloreto de sódio ( $\mathrm{NaCl})$ (Synth $\left.{ }^{\circledR}\right)$ e completou-se para $1.000 \mathrm{~mL}$ de água filtrada em Filtro Milli-Q plus $^{\circledR}$, em seguida esta solução foi colocada em um Becker e permaneceu no agitador magnético por 5 minutos. A solução foi armazenada em frasco previamente identificado mantido sob refrigeração $\left(2-8^{\circ} \mathrm{C}\right)$;

- Staphylococcus aureus (S. aureus) - Cepa ATCC 2593 (DIFCO®, DETROIT, MI, USA) marcadas com o flurocromo lodeto de Propídio (PI);

- Seleção das colônias de S. aureus: amostras viáveis de S. aureus foram cultivadas durante $48 \mathrm{~h}$ em meio ágar sangue, selecionadas em fluxo laminar e armazenadas em tubos estéreis. As bactérias foram resuspensas em $\mathrm{NaCl}$ 
$0,85 \%$, centrifugadas por 10 minutos a $1200 \mathrm{rpm}$ e inativadas em banho= maria a $60^{\circ} \mathrm{C}$ por 30 minutos. Foram lavadas por 3 vezes com $\mathrm{NaCl} 0,85 \%$ e centrifugadas a cada lavagem, por 10 minutos a 1200rpm;

- Ajuste da concentração de $S$. aureus: foi realizada a leitura em espectrofotômetro, no comprimento de onda de $620 \mathrm{~nm}$, obtendo os valores de absorbância entre 2,4 e 2,7. Valores estes equivalentes a turbidez de n8 na escala de McFarland, ideais para a leitura no citômetro de fluxo;

- Preparo da solução do fluorocromo lodeto de Propídio (PI) (Sigma®, SI, St Louis, MO, USA) a $5 \%{ }^{\circledR}$ ): foram diluídos $50,0 \mu \mathrm{L}$ PI em $1,0 \mathrm{~mL} \mathrm{NaCl} 0,9 \%$. Todo o procedimento foi realizado em fluxo laminar;

- Conjugação do S. aureus com o fluorocromo lodeto de Propídio (PI): as bactérias foram resuspensas em $\mathrm{NaCl} 0,85 \%$ e centrifugadas por 10 minutos a 1200rpm. O sobrenadante foi desprezado e adicionou-se $25.0 \mu \mathrm{L}$ da solução de PI 5\%. Procedeu-se a incubação no escuro por 30 minutos à temperatura ambiente. As bactérias foram lavadas por 3 vezes com $\mathrm{NaCl} 0,85 \%$, centrifugadas a cada lavagem por 10 minutos a 1200rpm e resuspensas em 5,0mL de solução de PBS glicosado. A solução final foi alíquotada em tubos para microcentrífuga de $2,0 \mathrm{~mL}$, protegidas da luz e congeladas $\left(-80^{\circ} \mathrm{C}\right)$, até o momento do uso;

- Solução de Ketamina + Xilazina: foi associado $1,0 \mathrm{~mL}$ de cloridrato de ketamina $10 \%$ (Dopalen $®$ ), a $0,5 \mathrm{~mL}$ de cloridrato de xilazina $2 \%$ (Anasedan $\AA$ ) em $8,5 \mathrm{~mL}$ de $\mathrm{NaCl}$ 0,9\%. A solução foi armazenada em frasco estéril previamente identificado e mantida sob refrigeração $\left(2-8^{\circ} \mathrm{C}\right)$. 


\subsubsection{Corantes celulares}

- Solução de azul de trypan: foi adicionado $1,0 \mathrm{~mL}$ de azul de trypan (Merck ${ }^{\circledR}$ ) em 5,0mL de PBS. Esta solução foi armazenada em frasco previamente identificado e mantida em temperatura ambiente;

- Corante de May-Grunwald modificado por Rosenfeld: foi adicionado 0,97g de Giemsa (Merck®), 0,53g de May-Grunwald (Merck®) em 1.000mL de Metanol (PA) (Synth $\AA$ ). Esta suspensão foi homogeneizada e armazenada em frasco âmbar durante 1 mês e filtrada toda vez antes de ser utilizada. A proporção de uso indicada para cada extensão de sangue foi de $1,5 \mathrm{~mL}$ de corante durante 5 minutos, acrescidas da mesma proporção de água durante 10 minutos. As extensões foram lavadas sob jato de água corrente e seca ao ar.

\subsubsection{Aparelhos}

- Centrífuga Refrigerada (Eppendorf ${ }^{\circledR}$, modelo 5180R);

- Citômetro de Fluxo - FACScalibur Becton Dickinson® Immunocytometry System, San Jose, California, USA, conectado ao computador Mancintosh Apple®, CA, USA;

- Contador Hematológico $A B C^{T M}$ VET ABX;

- Microscópio de Contraste de Fase Nikon ${ }^{\circledR}$;

- Sistema de análise de imagens computadorizado BIOSCAN/OPTIMAS ${ }^{\circledR}$, para avaliação morfométrica; 


\subsection{PROCEDIMENTOS}

Para execução dos diversos experimentos foram realizados os seguintes procedimentos:

\subsubsection{Preparo e administração da ração}

Devido a possibilidade de inativação dos princípios ativos pelo aquecimento e consequentemente perda da toxicidade das sementes quando da trituração em moinhos de facas, realizou-se o procedimento a frio, assim as sementes de Senna occidentalis foram separadas dos cotilédones, congeladas em nitrogênio líquido, trituradas em liquidificador comercial $\left(\right.$ Wallita ${ }^{\circledR}$ ) e incorporadas à ração comercial $\left(\right.$ Nuvital $\left.^{\circledR}\right)$. Foram adicionadas diferentes concentrações de sementes (1\%, 2\% e 4\%) à ração, sendo esta mistura homogeneizada em misturador (Marconi ${ }^{\circledR}$ modelo 206) e imediatamente peletizada.

3.4.1.2 Administração de ração para ratos recém-desmamados

Ratos recém-desmamados foram separados em cinco diferentes grupos: contole, os quais receberam apenas ração comercial; e exeperimentais tratados com $1 \%, 2 \%$ e $4 \%$ de $S$. occidentalis na ração durante 14 ou 28 dias. Existiu ainda um 
grupo de animais denominado peer-feeding, os quais receberam a mesma quantidade de ração consumida pelos animais tratados com So4, porém isentas de sementes da planta.

\subsubsection{Administração de ração ao grupo peer-feeding}

O experimento no qual se realizou a administração denominada peer-feeding, teve por objetivo fornecer a mesma quantidade de ração consumida pelos animais tratados com $4 \%$ de sementes de S. occidentalis (So4). Para tanto, iniciou-se a administração do grupo experimental So4, 24 horas antes de se administrar à ração comercial para os roedores do grupo peer-feeding; este procedimento permitiu o cálculo do consumo médio de ração pelos animais do grupo experimental So4; a quantidade obtida através da média consumida pelos animais do grupo experimental So4 foi administrada para os animais pertencentes ao grupo peer-feeding.

\subsubsection{Administração de ração para fêmeas gestantes}

Após a constatação da prenhez, as fêmeas foram mantidas individualmente em gaiolas e receberam até $05^{\circ}$ dia de gestação ração comercial ad libitum. Do $6^{\circ}$ ao $20^{\circ}$ dia de gestação, procedeu-se a administração de sementes de S. occidentalis, incorporadas à ração nas concentrações de 1\%, 2\% e 4\%, Existiu 
ainda um grupo de animais denominado peer-feeding, os quais receberam a mesma quantidade de ração consumida pelos animais tratados com So4, porém isentas de sementes da planta.

\subsubsection{Avaliação do consumo de ração, ganho de peso e observações clínicas}

Os animais foram pesados individualmente, logo antes do início da administração das sementes de $S$. occidentalis misturadas na ração. $O$ acompanhamento dos animais quanto ao ganho de peso e consumo de ração, foi realizado a cada 2 dias do tratamento. Para avaliar o consumo de ração e o ganho de peso, os animais foram pesados em balança semi-analítica (Marte ${ }^{\circledR}$ ), no período matutino entre 8 e 9 horas. As observações clínicas foram realizadas a cada 2 dias e os seguintes sinais e sintomas eram avaliados: presença de fezes amolecidas, letargia, abatimento e pêlos arrepiados.

\subsubsection{Cesariana}

A técnica cirúrgica cesariana foi realizada após 8 h de jejum. As ratas prenhes foram anestesiadas com a solução de ketamina + xilazina na dose $1 \mathrm{~mL} / \mathrm{kg}$, e em seguida, procedeu-se a laparotomia exploratória, com exposição dos cornos uterinos, para a contagem de pontos de implantações, de reabsorção e de fetos 
vivos e mortos. Os ovários foram retirados e com o auxílio de uma lupa (16/12 x 1,25), procedeu-se a contagem do número de corpos lúteos para a avaliação da quantidade de óvulos eliminados. Para melhor visualização dos pontos de implantação, o útero foi mergulhado em solução de sulfeto de amônio a 25\% por 10 minutos e em seguida lavado em água corrente, tendo os pontos de implantação corados em preto. As perdas embrionárias no período de pós-implantação foram calculadas por meio da seguinte proporção:

$$
\begin{aligned}
& \text { \% perda pré-implantação }=(C L-I M) \times 100 / C L \\
& \% \text { perda pós-implantação }=(I M-F V) \times 100 / I M
\end{aligned}
$$

Considerando-se:

$$
\begin{aligned}
& \mathrm{CL}=\text { Número de corpos lúteos } \\
& \mathrm{IM}=\text { Número de implantações } \\
& \mathrm{FV}=\text { Número de fetos vivos }
\end{aligned}
$$

\subsubsection{Padronização da ninhada}

No dia seguinte ao nascimento dos animais, procedeu-se com a padronização de cada ninhada permanecendo 4 machos e 4 fêmeas para cada progenitora e, caso não fosse possível, foi realizada a troca de ninhada (cross fostering) para que esta relação seja mantida. Durante a lactação, o peso das ninhadas será verificadas nos dia 1, 3, 6, 9, 12, 15, 18 e 21, deste período. 


\subsubsection{Avaliação do hemograma}

O hemograma foi constituído pelo eritrograma e pelo leucograma. Ao final do período de avaliação, os animais foram anestesiados com a solução de ketamina + xilazina na dose de $1 \mathrm{~mL} / \mathrm{kg}$. Imediatamente foi realizada a coleta de sangue, por punção da veia hepática, em seringas não heparinizadas. Estas coletas foram realizadas no período matutino entre 8 e 9 horas da manhã. Foram colhidos $5,00 \mathrm{~mL}$ de sangue, que foram transferidos para um frasco contendo $0,05 \mu$ l de solução aquosa de etilenodiamino-tetracético-dissódico (EDTA) a 10\%, produzindo-se adequada homogeneização. O hemograma foi realizado segundo procedimento recomendado por Birgel (1982) e com o auxílio do contador hematológico $A B C^{T M}$ VET ABX, respectivamente. A contagem diferencial de leucócitos foi determinada por meio da contagem global destas células em extensão sanguínea coradas por May-Grunwald modificado por Rosenfeld.

\subsubsection{Avaliação do burst oxidativo e da fagocitose de neutrófilos e de macrófagos por citometria de fluxo}

Para execução das técnicas do burst oxidativo e da fagocitose de neutrófilos e de macrófagos, por citometria de fluxo do sangue periférico de ratos Wistar, foram realizados os protocolos abaixo descritos. 
Foi utilizado o método proposto por Hasui et al. (1989) para análise do burst oxidativo desencadeado por diferentes estímulos. Após, a morte por decapitação, o sangue foi coletado. Uma bateria de 5 tubos numerados de "A" até "E", foi preparado; sendo que cada tubo, de acordo com a sua letra, recebeu uma substância diferente, obedecendo-se sempre a uma mesma ordem (Figura 2).
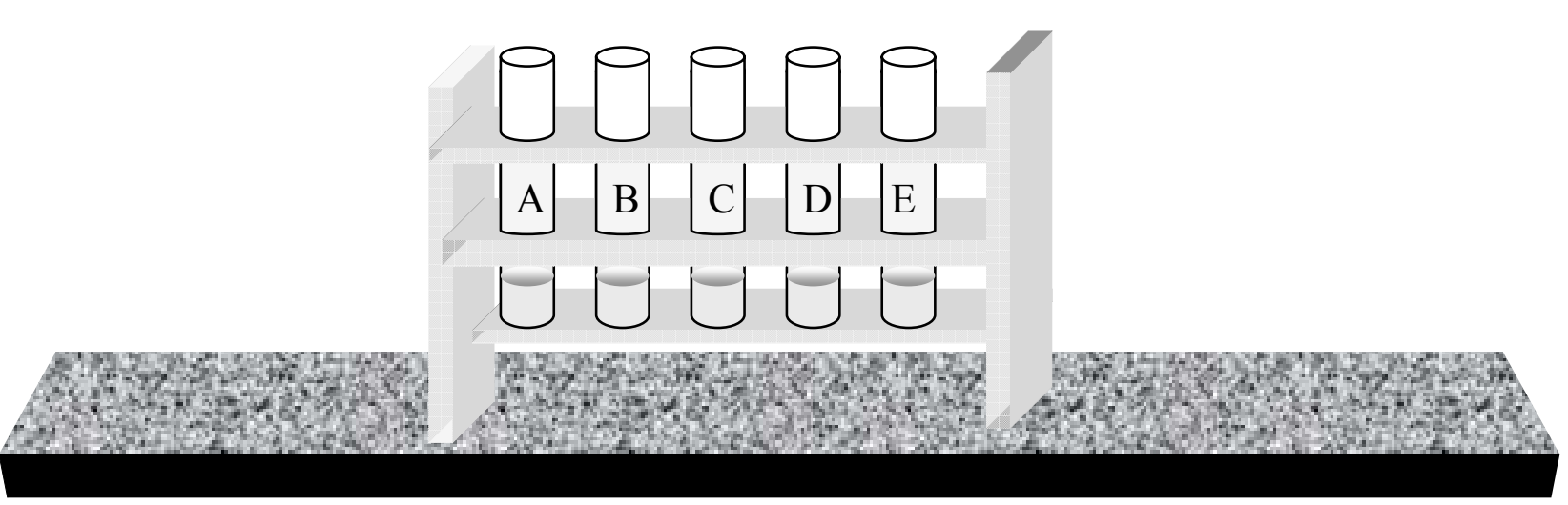

$$
\begin{aligned}
& A=\text { Células (Sangue) } \\
& B=\text { Células }+D C F H \\
& C=\text { Células }+ \text { SAPI } \\
& D=\text { Células }+ \text { DCFH }+ \text { SAPI } \\
& E=\text { Células }+ \text { DCFH }+ \text { PMA }
\end{aligned}
$$

Figura 2 - Representação esquemática de sequências de reagentes utilizados nas técnicas de burst oxidativo e fagocitose: Tubo A - PBS; Tubo B - DCFH; Tubo C - SAPI; Tubo D - DCFH+SAPI, Tubo E - DCFH+PMA. Adaptado de Costa, 2004

Desta forma, todos os tubos de "A" a "E" receberam alíquotas que correspondem a 2 × $10^{5}$ cél/ $100 \mu l$ de sangue. Os tubos com as letras "B", "D" e "E" receberam 200,0 $\mu$ l da solução de 2,7- Diclorodihidrofluoresceína-diacetato (DCFHDA) 3mM cada. Os tubos de letra "C" e "D" receberam 100,0 $\mu$ la solução de Staphylococcus aureus marcado com iodeto de propídeo (SAPI) $(100,0 \mathrm{ng})$. O tubo de letra "E" recebeu 100,0 $\mu$ l de miristato-acetato de forbol (PMA) (100,0ng). 
Como as amostras devem apresentar um volume final de $1100 \mu$, todos os tubos foram completados com PBS 1x. Sendo assim, todos os tubos "A" receberam $1000,0 \mu l$ de PBS, os tubos "B" $800 \mu l$, os "C", 900,0 1 l e, finalmente, os tubos "D" e "E" receberam $700 \mu$ l.

Em seguida, os tubos foram incubados em banho-maria sob agitação a $37^{\circ} \mathrm{C}$, por 30 minutos. Depois da incubação, foram adicionados 2,0ml de EDTA 3mM para interromper a reação, sendo os tubos centrifugados posteriormente a 1200rpm, por 10 minutos.

Após a centrifugação, desprezou-se o sobrenadante. As células foram resuspensas por agitação manual, realizando-se a seguir a lise hipotônica das amostras com soluções de $\mathrm{NaCl}$ a $0,2 \%$ e 1,6\%. Primeiramente, foi colocado em cada tubo $2,0 \mathrm{ml}$ de $\mathrm{NaCl}$ a $0,2 \%$, durante 20 segundos. Imediatamente após este período, colocaram-se mais $2,0 \mathrm{ml}$ de $\mathrm{NaCl}$ a $1,6 \%$ para tornar a solução isotônica novamente.

Em sequência, os tubos foram centrifugados novamente, sendo desprezados os sobrenadantes obtidos. Foi, então, realizada uma nova lise hipotônica (pela segunda vez), seguindo todo o procedimento citado acima. Após a segunda lise, os tubos foram centrifugados pela última vez, sendo os sobrenadantes desprezados. As células resultantes foram resuspensas em 200,0 $\mu$ l de PBS gelado.

Após todo este procedimento, efetuou-se a leitura das amostras no citômetro de fluxo, sendo que o tubo "A" foi utilizado para a calibração do aparelho (fluorescência basal das células), os tubos "C" e "D" foram utilizados para a avaliação da fagocitose, enquanto que o restante dos tubos foi utilizado na avaliação do burst oxidativo. 
Cada amostra passou pelo citômetro apenas uma vez e, de cada uma, foram adquiridos 10000 eventos (células). Os valores referentes ao burst oxidativo das amostras foram avaliados por meio da média geométrica da intensidade de fluorescência emitida pela população de células. Este valor, ou seja, a média geométrica (geo mean) é dada pelo aparelho e foi esta unidade utilizada para se avaliar a intensidade de fluorescência das células.

Com relação à atividade fagocítica, verificou-se a porcentagem de fagocitose, ou seja, o número de macrófagos que fagocitaram o SAPI e, consequentemente, fluorescentes, dividido pelo número total destas células, multiplicadas por 100 .

Foi avaliada, também, a intensidade de fagocitose (quantidade de bactérias fagocitadas). Os valores da intensidade de fagocitose também foram registrados por meio da média geométrica da intensidade de fluorescência emitida pelas células. Para a aquisição dos dados foi utilizado o software CellQuest Pro e para a análise dos dados o Flowjo versão 7.2.5.

\subsubsection{Avaliação da resposta imune celular por meio da reação de hipersensibilidade do tipo tardia - Delayed Type Hypersensitivity test (DTH)}

Para a sensibilização imunológica dos ratos, foi injetado, por via subcutânea (sc), na base da cauda de cada animal, 0,1ml de BSA - Fração V (Bovine serum albumin - fraction V) em (1,0mg/mL PBS) emulsificado em Adjuvante Completo de Freud (FCA) na razão de 1:1. 
Sete dias após a sensibilização, preparou-se o heat-aggregated BSA, aquecendo-se o BSA $\left(10,0 \mathrm{mg} / \mathrm{ml}\right.$ em salina) por 1 hora em banho-maria a $75^{\circ} \mathrm{C}$. Esta solução foi centrifugada a 2000rpm, por 10 minutos, para remover o excesso de salina; a seguir a solução foi injetada $(0,1 \mathrm{~mL} /$ por animal) no coxim plantar direito dos animais e, na pata contra-lateral injetou-se o mesmo volume de solução salina.

Após 24 horas de desafio com o heat-aggregated BSA, o edema resultante foi mensurado com micrometro padronizado. A avaliação da resposta imune celular (DTH) foi expressa a partir da subtração do valor obtido na mensuração do coxim plantar da pata direita (BSA) 24 horas depois do desafio com aquele valor da mensuração antes do inóculo.

\subsubsection{Avaliação da celularidade do baço e medula óssea}

A celularidade do baço foi determinada, após o peso total do baço e corte da extremidade do órgão, previamente pesado. Procedeu-se então, a dissociação do fragmento em meio RPMI-1640 com auxílio de lâminas para microscopia Perfecta ${ }^{\circledR}$.

Estas células foram mantidas em banho de gelo, dentro de placas especiais de plástico (Costar ${ }^{\circledR} n^{\circ}$ 3424), até serem quantificadas em câmara de Neubauer, sendo a viabilidade celular das mesmas observadas pela coloração com azul de trypan 6\%, aceitando-se no mínimo 95\% de viabilidade.

Para determinar a celularidade da medula óssea, foi utilizado o fêmur esquerdo de cada animal. O conteúdo da medula óssea foi lavado com 10,0mL de meio RPMI-1640 e a suspensão resultante foi acondicionada em tubos de 
polipropileno de $10,0 \mathrm{~mL}$, dentro de um banho de gelo. Imediatamente, as células da medula óssea foram contadas, utilizando-se a técnica descrita por Raissuddin et al. (1990).

\subsubsection{Estudo Anátomo e Histopatológico}

Para execução do estudo anátomo e histopatológico foram realizados os seguintes protocolos:

\subsubsection{Microscopia óptica}

Os animais foram anestesiados com a solução de ketamina + xilazina na dose de $1 \mathrm{~mL} / \mathrm{kg}$ e procedeu-se a coleta de coleta de fragmentos representativos do baço, timo, linfonodos fígado e intestino. Estes fragmentos foram fixados em metacarn durante 24 horas, após este período, esta solução foi substituída por álcool a 70\%; posteriormente, o material foi incluído em parafina, cortado e corado com hematoxilina-eosina (HE), para observação de possíveis alterações à microscopia óptica. 


\subsection{DELINEAMENTO EXPERIMENTAL}

Para realização dos diversos experimentos, estes foram delineados conforme a seguinte descrição:

3.5.1 Experimento 1: Avaliação do sistema imune e hematopoético, de ratos recém-desmamados, tratados com diferentes concentrações de S. occidentalis na ração.

Este experimento foi delineado conforme a seguinte descrição

\subsubsection{Experimento 1.1: Avaliação hematológica}

Foram utilizados 50 ratos separados em 5 grupos iguais, com aproximadamente 21 dias de idade, conforme descrito no item 3.1.1. Os ratos dos grupos experimentais receberam, diariamente, por um período de 14 ou 28 dias, ração contendo $1 \%, 2 \%$ e $4 \%$ de S. occidentalis, conforme descrito no item 3.4.1.2 Os animais do grupo controle, assim como aqueles do grupo peer-feeding receberam a ração sem adição das sementes da planta, durante todo o período experimental. Após este período, procedeu-se a anestesia dos animais, com a 
solução de ketamina + xilazina na dose de $1 \mathrm{~mL} / \mathrm{kg}$ para as avaliações hematológicas, celulares, citológicas conforme descritas nos itens 3.4.5 e 3.4.8, respectivamente. Destes mesmos animais, foram escolhidos, ao acaso, 3 animais de cada grupo dos quais foram coletadas amostras de tecidos para a realização dos exames anatomopatológicos e morfométricos, conforme descritos nos itens 3.4 .9 e 3.4.9.1, respectivamente.

3.5.1.2 Experimento 1.2: Avaliação do burst oxidativo e da fagocitose de neutrófilos por citometria de fluxo, de ratos recém-desmamados, tratados com diferentes concentrações de S. occidentalis na ração

Foram utilizados 50 ratos separados em 5 grupos iguais, com aproximadamente 21 dias de idade, conforme descrito no item 3.1.1. Os ratos dos grupos experimentais receberam, diariamente, por um período de 14 dias ou 28 dias, ração contendo $1 \%, 2 \%$ e $4 \%$ de S. occidentalis, conforme descrito no item 3.4.1.2. Após este período os animais foram avaliados quanto à indução do burst oxidativo e da fagocitose de neutrófilos e de macrófagos por citometria de fluxo, conforme o item 3.4.6. 
3.5.1.3 Experimento 1.3: Avaliação da resposta imune celular por meio da reação de hipersensibilidade do tipo tardia (DTH), de ratos recém-desmamados, tratados com diferentes concentrações de S. occidentalis na ração.

Foram utilizados 50 ratos separados em 5 grupos iguais, com aproximadamente 21 dias de idade, conforme descrito no item 3.1.1. Os ratos dos grupos experimentais receberam, diariamente, por um período de 14 dias ou 28 dias, ração contendo $1 \%, 2 \%$ e $4 \%$ de S. occidentalis, conforme descrito no item 3.4.1.2 Após este período os animais foram avaliados quanto ao DTH, conforme o item 3.4.7.

\subsubsection{Experimento 2: Efeitos da administração prolongada das sementes de S. occidentalis, em ratas durante o período de gestação}

Para a verificação dos efeitos da administração de sementes de S. occidentalis a ratas durante o período de prenhez e nos respectivos fetos, foram utilizadas 50 ratas prenhes divididas em 5 grupos iguais, as quais receberam, diariamente, do $6^{\circ}$ ao $19^{\circ}$ dia de prenhez ração contendo $1 \%$ (So1\%), $2 \%$ (So2\%) e 4\% (So4) de S. occidentalis na ração conforme descrito no item 3.4.1.4 Aqueles animais do grupo controle e peer-feeding receberam apenas a ração comercial, durante todo o período experimental. Durante este período, foi observado o estado geral dos animais, bem como a ocorrência de abortos. O consumo ração e ganho de 
peso foram verificados conforme descrito no item 3.4.2, nos períodos, compreendidos entre o $6^{\circ}$ ao $19^{\circ}$ dia de gestação.

No $19^{\circ}$ dia de prenhez, a ração foi retirada no período noturno, e no $20^{\circ}$ dia, pela manhã, as mães foram anestesiadas e foi realizada a cesariana, conforme descrito no item 3.4.3 e procedeu-se a coleta de sangue para determinação do hemograma, como descrito no item 3.4.5. A seguir, estes animais foram submetidos à eutanásia para análise celular, conforme descrito no iten 3.4 .8 , respectivamente. Destes mesmos animais, foram escolhidos, ao acaso, 4 animais de cada grupo dos quais foram coletadas amostras de tecidos para a realização dos exames anatomopatológicos, conforme descrito no iten 3.4.9.

3.5.2.1 Experimento 2.1: Avaliação do sistema imune e hematopoético, na prole de ratas tratadas com 0 e $4 \%$ de sementes de $S$. occidentalis na ração e seu grupo peer-feeding.

Foram utilizadas 50 ratas prenhes divididas em 3 grupos iguais, as quais receberam, diariamente, do $6^{\circ}$ ao $19^{\circ}$ dia de prenhez ração contendo $4 \%$ (So4) de $S$. occidentalis na ração, conforme descrito no item 3.4.1.4. Aqueles animais do grupo controle e peer-feeding receberam apenas a ração. O consumo de ração e ganho de peso foram verificados conforme descrito no item 3.4.2, nos períodos, compreendidos entre o $6^{\circ}$ ao $19^{\circ}$ dia de gestação. No dia seguinte ao nascimento, todas as proles foram homogeneizadas, foram escolhidos aleatoriamente, sempre que possível, 4 filhotes de cada sexo, para cada mãe. Estes animais totalizaram 40 
fêmeas e 40 machos e foram separados em dois subgrupos iguais, com 20 fêmeas e 20 machos, para a realização dos protocolos experimentais, como descrito a seguir:

\subsection{Experimento 2.1.1: Avaliação hematológica}

No $22^{\circ}$ dia de lactação, foram utilizados 10 filhotes, fêmeas e machos, de cada grupo, os quais foram anestesiados com a solução de ketamina + xilazina na dose de $1 \mathrm{~mL} / \mathrm{kg}$ para as avaliações hematológicas, celulares, citológicas conforme descritas nos itens 3.4 .5 e 3.4.8, respectivamente. Destes mesmos animais, foram escolhidos, ao acaso, 3 animais de cada grupo, dos quais foram coletadas amostras de tecidos para a realização dos exames anatomopatológicos, conforme descrito nos iten 3.4.9.

3.5.2.1.2 Experimento 2.1.2: Avaliação do burst oxidativo e da fagocitose de neutrófilos e de macrófagos por citometria de fluxo

No $22^{\circ}$ dia de lactação, foram utilizados 10 filhotes, fêmeas e machos, de cada grupo, os quais foram submetidos a morte por decaptação para coleta de sangue. Após este período os animais foram avaliados quanto à indução do burst 
oxidativo e da fagocitose de neutrófilos e de macrófagos por citometria de fluxo, conforme o item 3.4.6.

3.5.2.1.3 Experimento 2.1.3: Avaliação da resposta imune celular por meio da reação de hipersensibilidade do tipo tardia - Delayed Type Hypersensitivity test (DTH)

No $22^{\circ}$ dia de lactação, foram utilizados 10 filhotes, fêmeas e machos, de cada grupo. Após este período os animais foram avaliados quanto ao DTH, conforme o item 3.4.7.

\subsection{ANÁLISE ESTATÍSTICA}

A avaliação da homocedasticidade dos dados, entre os diferentes grupos foi realizada pelo teste de Bartlett, diferenciando os dados paramétricos daqueles não paramétricos (GAD; WEIL, 1989).

Para os dados paramétricos, empregou-se a análise de variância ANOVA, proposta por Snedecor (1946), seguido pelo teste de Dunnett para comparação entre os diversos grupos experimentais e o grupo controle. 
O teste "t" de Student foi empregado para a comparação dos dados obtidos entre os grupos de ratos que receberam $4 \%$ de sementes de $S$. occidentalis na ração (grupos experimentais) ou não (grupos peer-feeding).

A probabilidade de $p<0,05$ foi considerada capaz de revelar diferenças significantes entre os grupos. Para a análise estatística, foi empregado o software GraphPad Instat v 3.00 para Windows $95^{\circledR}$ (GRAPHPAD INSTAT, 1998). Os gráficos obtidos após a análise dos dados foram confeccionados por meio do programa GraphPad Prisma v 3.00 para Windows $95^{\circledR}$ (GRAPHPAD PRISM, 1999).

Para a estatística descritiva são apresentados as médias e os respectivos desvios-padrões para os dados paramétricos. 
4 RESULTADOS 


\section{RESULTADOS}

\subsection{EXPERIMENTO 1: AVALIAÇÃO DO SISTEMA IMUNE E HEMATOPOÉTICO,} DE RATOS EM RECÉM-DESMAMADOS, TRATADOS COM DIFERENTES CONCENTRAÇÕES DE S. occidentalis NA RAÇÃO DURANTE 14 DIAS

A tabela 1 mostra e a figura 3 ilustra o consumo médio e total de ração pelos ratos durante o experimento. Assim, a análise estatística realizada revelou haver diferença significante entre os grupos nos $2^{\circ}, 6^{\circ}, 8^{\circ}, 10^{\circ}$ e $12^{\circ}$ dias do experimento $\left(F_{2}=3,434 ; \quad F_{6}=15,47 ; \quad F_{8}=9,204 ; \quad F_{10}=27,50 ; \quad F_{12}=6,64 ; d f=3 / 35\right.$, respectivamente, $p<0,05)$, bem como no período total $(F=18,383$ e $d f=3 / 35)$ do experimento, sendo que o consumo de ração dos animais do grupo $\mathrm{PF}$ foi idêntico àquele dos ratos submetidos à administração de ração contendo $4 \%$ de sementes de S. occidentalis (dados não apresentados). A aplicação do teste de Dunnett apontou diminuição significante $(p<0,05)$ no consumo de ração dos animais tratados com So4\% no $2^{\circ}$, $6^{\circ}, 8^{\circ}, 10^{\circ}$ e $12^{\circ}$ dias do experimento, quando comparado aos animais do grupo controle. Na avaliação do consumo total de ração, o teste de Dunnett revelou haver diminuição significante $(p<0,05)$ neste parâmetro nos animais pertencentes aos grupos experimentais So2\% e So4\%, quando comparado aos animais do grupo controle.

Em relação ao peso médio destes animais (Tabela 2 e Figura 4), as análises de variância realizadas revelaram haver diferença significante entre os grupos nos 
$6^{\circ}, 8^{\circ}, 10^{\circ}, 12^{\circ}$ e $14^{\circ}$ dias do experimento $\left(F_{6}=4,252 ; F_{8}=14,53 ; \quad F_{10}=29,12\right.$; $F_{12}=32,39 ; F_{14}=26,22 ; d f=4 / 44$, respectivamente, $\left.p<0,05\right)$, bem como no período total $(F=7,981$ e $d f=4 / 44)$, quando comparado aos resultados obtidos dos animais pertencentes ao grupo controle. A aplicação do teste de Dunnett mostrou redução significante $(p<0,05)$ deste parâmetro no $12^{\circ}$ e $14^{\circ}$ dias de tratamento pelos animais pertencentes ao grupo So2\%, em relação aos animais do grupo controle. Este mesmo teste apontou ainda, diminuição significante $(p<0,05)$ no ganho de peso daqueles ratos pertencentes ao grupo So $4 \%$ no $6^{\circ}, 8^{\circ}, 10^{\circ}, 12^{\circ}$ e $14^{\circ}$ dias do experimento, em relação aos animais do grupo controle.

Os ganhos de peso médios semanais e totais destes ratos são apresentados na tabela 3 e ilustrados na figura 5. A análise de variância realizada revelou haver diferença significante entre os grupos na $1^{\circ}$ e $2^{\circ}$ semanas $\left(F_{1}=9,954 ; F_{2}=13,861\right.$; $d f=4 / 45$, respectivamente, $p<0,05)$, bem como no período total $(F=24,18$ e $d f=4 / 44)$ do experimento. A aplicação do teste de Dunnett mostrou diminuição significante $(p<0,05)$ no ganho de peso semanal dos animais tratados com So2\% e So4\% na primeira semana de avaliação. Este mesmo teste apontou, ainda, redução significante $(p<0,05)$ de peso na $2^{\circ}$ semana de tratamento apenas nos animais So4\%. Na avaliação do ganho de peso total, apenas os animais pertencentes ao grupo So2\% e So4\% apresentaram diminuição deste parâmetro quando comparados aos animais do grupo controle.

Em relação às observações clínicas, os seguintes sinais e sintomas, foram observados: letargia, abatimento, prostração, pêlos arrepiados e fezes amolecidas, a partir da segunda semana de tratamento em todos os animais pertencentes ao grupo So4\%. 
Os resultados dos efeitos da administração de ração contendo diferentes concentrações de sementes de $S$. occidentalis sobre os parâmetros hematológicos de ratos são apresentados na tabela 4 . O número médio de eritrócitos (RBC) e leucócitos (WBC) e os valores médios de hemoglobina $(\mathrm{Hb})$, hematócrito $(\mathrm{HCT})$, volume corpuscular médio (VCM), hemoglobina corpuscular média (HCM) e concentração de hemoglobina corpuscular média ( $\mathrm{CHCM}$ ) são apresentados. A análise estatística revelou não haver diminuição significante $(p>0,05)$ em nenhum dos parâmetros avaliados, entre os animais tratados com a planta, em comparação aos animais pertencentes ao grupo controle. Na contagem diferencial de leucócitos nenhuma alteração significante $(p>0,05)$ foi observada entre os animais tratados quando comparados aos ratos do grupo controle, como apresentado na tabela 5.

Os resultados obtidos na avaliação do peso relativo do baço e timo dos animais tratados com as diferentes concentrações de $S$. occidentalis na ração são apresentados na tabela 6 e ilustrados na figura 6. A análise estatística revelou haver diferença significante $(p<0,05)$ no peso relativo do baço e timo $\left(F_{\text {baço }}=10,97 ; F_{\text {timo }}=\right.$ 15,88; $d f=4 / 44$, respectivamente, $p<0,05)$. A aplicação do teste de Dunnett apontou aumento significante $(p<0,05)$, no peso relativo do baço dos animais pertencentes aos grupos So2\% e So4\%, quando comparado aos animais do grupo controle. Por outro lado, este mesmo teste revelou haver diminuição significante $(p<0,05)$ no peso relativo do timo dos animais pertencentes aos grupos So4\% e PF, em relação aos animais pertencentes ao grupo controle.

A tabela 7 mostra a celularidade do baço e medula óssea, e a figura 7 ilustra a celularidade da medula óssea de ratos tratados com as diferentes concentrações de $S$. occidentalis na ração. A análise estatística apontou diferença significante $(p<0,05)$, na celularidade da medula óssea $(M O)\left(F_{M O}=2,518 ; d f=4 / 44\right)$. A aplicação 
do teste de Dunnett apontou diminuição significante $(p<0,05)$ na celularidade da medula óssea dos animais tratados com So2\% e So4\%, em relação aos animais pertencentes ao grupo controle.

Em relação ao estudo histopatológico de fragmentos histológicos provenientes do timo, linfonodos, fígado e de diferentes porções do intestino, nenhuma alteração morfológica digna de nota foi observada em qualquer das amostras colhidas, de animais pertencentes aos diferentes grupos experimentais.

Por outro lado, a análise morfológica do baço dos animais tratados com $4 \%$ de sementes de $S$. occidentalis na ração apresentou: desorganização do parênquima esplênico, proliferação hematopoiética extramedular caracterizada pela incidência de progenitores eritróides em diferentes estágios de maturação, siderócitos e megacariócitos multinucleados (Figura 8). 
Tabela 1 - Consumo médio e total de ração (em g) pelos ratos recém-desmamados tratados durante 14 dias com diferentes concentrações $(0 \%, 1 \%, 2 \%$ e $4 \%)$ de sementes de S. occidentalis, na ração. Foram utilizados 10 animais por grupo. São apresentados as médias e os respectivos desvios padrões

\begin{tabular}{|c|c|c|c|c|}
\hline \multirow{2}{*}{ Dias de tratamento } & \multicolumn{4}{|c|}{ Senna occidentalis (\%) } \\
\hline & 0 & 1 & 2 & 4 \\
\hline $2^{\circ}$ & $26,0 \pm 3,6$ & $23,6 \pm 5,0$ & $24,6 \pm 3,2$ & $20,6 \pm 3,2^{a}$ \\
\hline $4^{\circ}$ & $24,7 \pm 3,1$ & $27,0 \pm 4,1$ & $23,6 \pm 2,1$ & $23,9 \pm 4,4$ \\
\hline $6^{\circ}$ & $29,0 \pm 1,7$ & $29,7 \pm 0,9$ & $27,0 \pm 2,5$ & $22,0 \pm 4,4^{a}$ \\
\hline $8^{\circ}$ & $28,3 \pm 1,8$ & $28,8 \pm 1,3$ & $25,2 \pm 3,2$ & $22,5 \pm 4,5^{a}$ \\
\hline $10^{\circ}$ & $30,0 \pm 0,1$ & $29,3 \pm 1,4$ & $26,0 \pm 4,4$ & $18,1 \pm 4,3^{a}$ \\
\hline $12^{\circ}$ & $28,9 \pm 4,3$ & $29,5 \pm 2,1$ & $26,6 \pm 2,5$ & $24,0 \pm 3,0^{a}$ \\
\hline $14^{\circ}$ & $29,1 \pm 4,5$ & $28,4 \pm 2,4$ & $27,0 \pm 4,8$ & $25,6 \pm 2,9$ \\
\hline Total & $28,0 \pm 1,9$ & $28,0 \pm 2,1$ & $25,7 \pm 1,3^{a}$ & $22,3 \pm 2,4^{a}$ \\
\hline
\end{tabular}



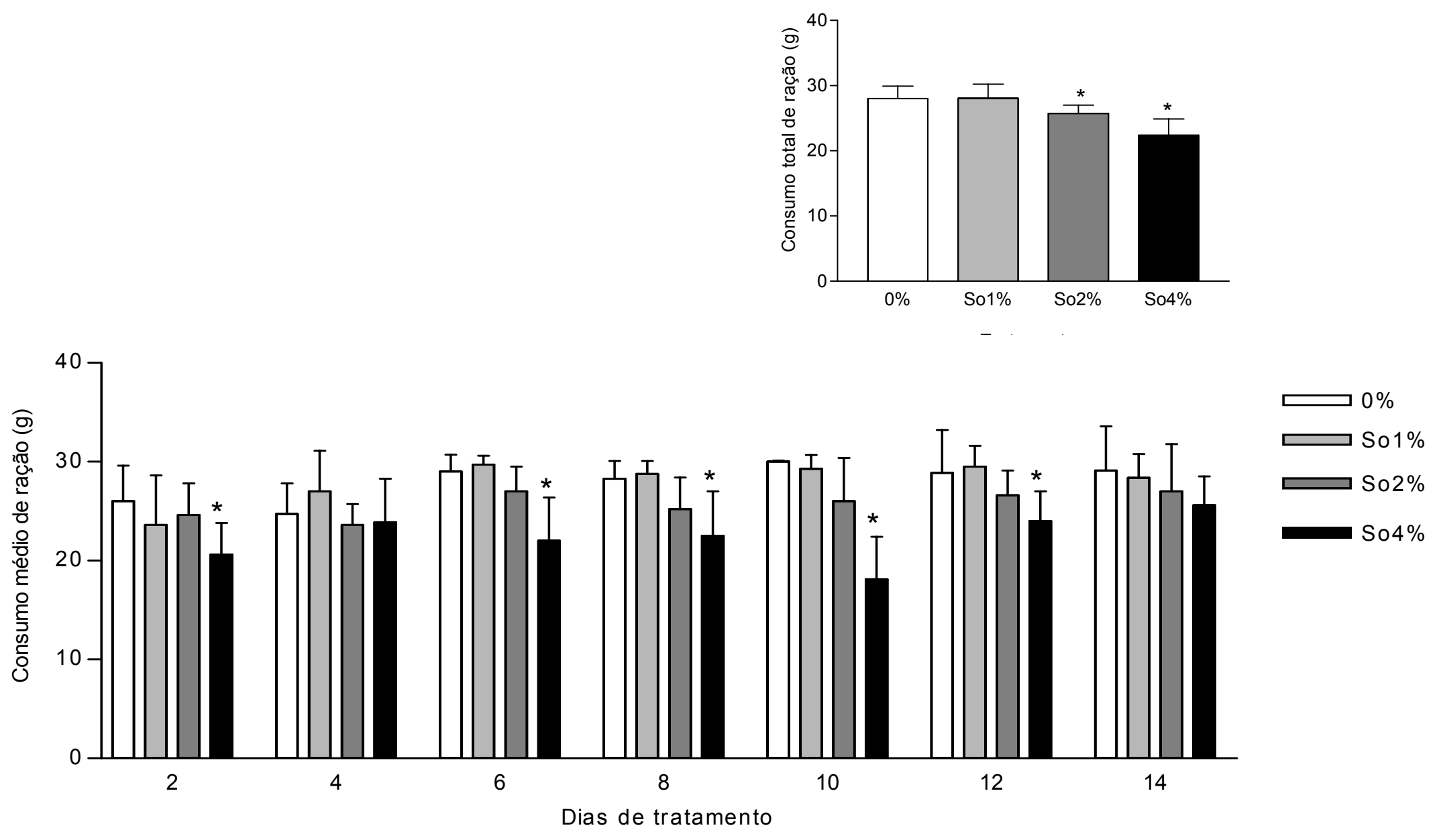

* difere significantemente $(p<0,05)$ em relação ao controle $(0 \%)$ - (ANOVA, seguida de Dunnett).

Figura 3 - Consumo médio e total de ração (em g) pelos ratos recém-desmamados tratados durante 14 dias com diferentes concentrações $(0 \%, 1 \%, 2 \%$ e $4 \%)$ de sementes de S. occidentalis, na ração. Foram utilizados 10 animais por grupo. São apresentados as médias e os respectivos desvios padrões 
Tabela 2 - Peso médio (em g), de ratos recém-desmamados tratados durante 14 dias com diferentes concentrações $(0 \%, 1 \%$, $2 \%$ e $4 \%$ ) de sementes de $S$. occidentalis, na ração e seu grupo peer-feeding (PF). Foram utilizados 10 animais por grupo. São apresentados as médias e os respectivos desvios padrões

\begin{tabular}{|c|c|c|c|c|c|}
\hline \multirow{2}{*}{ Dias de tratamento } & \multicolumn{5}{|c|}{ Senna occidentalis (\%) } \\
\hline & 0 & 1 & 2 & 4 & PF \\
\hline $2^{\circ}$ & $90,0 \pm 16,2$ & $92,2 \pm 2,7$ & $96,2 \pm 4,8$ & $93,0 \pm 4,8$ & $98,1 \pm 6,6$ \\
\hline $4^{\circ}$ & $101,7 \pm 16,1$ & $109,8 \pm 4,4$ & $103,5 \pm 9,0$ & $100,6 \pm 5,8$ & $107,8 \pm 6,2$ \\
\hline $6^{\circ}$ & $109,7 \pm 14,1$ & $110,0 \pm 3,0$ & $109,0 \pm 4,4$ & $100,1 \pm 8,6^{a b}$ & $114,3 \pm 5,2$ \\
\hline $8^{\circ}$ & $122,1 \pm 12,4$ & $121,8 \pm 3,6$ & $114,8 \pm 6,5$ & $98,6 \pm 10,5^{a b}$ & $120,2 \pm 4,4$ \\
\hline $10^{\circ}$ & $126,0 \pm 11,6$ & $127,7 \pm 4,0$ & $118,7 \pm 7,5$ & $95,0 \pm 9,6^{a b}$ & $125,1 \pm 4,2$ \\
\hline $12^{\circ}$ & $135,6 \pm 13,5$ & $134,8 \pm 6,7$ & $124,9 \pm 7,8^{a}$ & $97,3 \pm 8,9^{a b}$ & $130,0 \pm 4,7$ \\
\hline $14^{\circ}$ & $138,7 \pm 10,4$ & $135,9 \pm 4,9$ & $125,5 \pm 16,0^{a}$ & $98,0 \pm 9,9^{a b}$ & $135,5 \pm 3,5$ \\
\hline
\end{tabular}

\footnotetext{
a difere significantemente $(p<0,05)$ em relação ao controle $(0 \%)$ - (ANOVA,seguida de Dunnett).
}

${ }^{b}$ difere significantemente $(p<0,05)$ em relação ao PF (Teste "t" Student). 


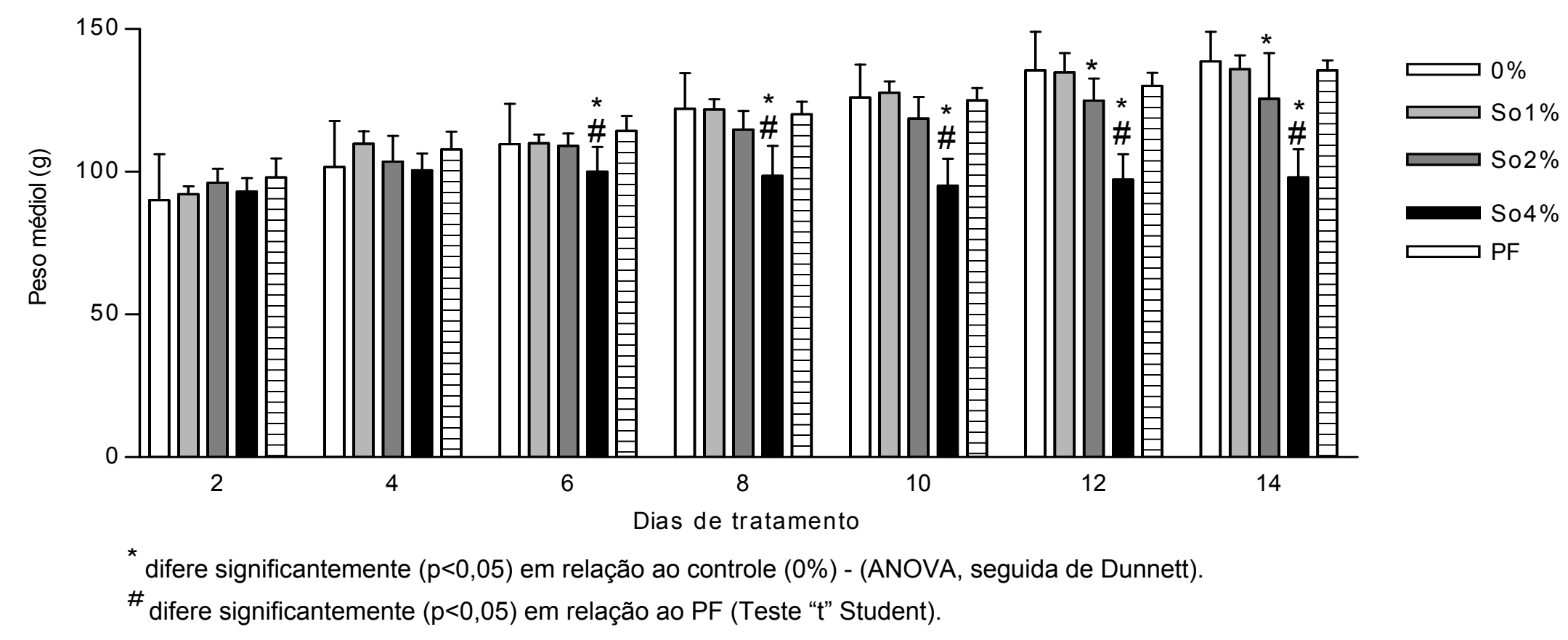

Figura 4 - Peso médio (em g), de ratos recém-desmamados tratados durante 14 dias com diferentes concentrações $(0 \%, 1 \%$, $2 \%$ e $4 \%$ ) de sementes de S. occidentalis, na ração e seu grupo peer-feeding (PF). Foram utilizados 10 animais por grupo. São apresentados as médias e os respectivos desvios padrões 
Tabela 3 - Peso semanal e total (em g), de ratos recém-desmamados tratados durante 14 dias com diferentes concentrações $(0 \%, 1 \%, 2 \%$ e $4 \%)$ de sementes de $S$. occidentalis, na ração e seu grupo peer-feeding (PF). Foram utilizados 10 animais por grupo. São apresentados as médias e os respectivos desvios padrões

\begin{tabular}{|c|c|c|c|c|c|}
\hline \multirow{2}{*}{$\begin{array}{l}\text { Semanas de } \\
\text { tratamento }\end{array}$} & \multicolumn{5}{|c|}{ Senna occidentalis (\%) } \\
\hline & 0 & 1 & 2 & 4 & PF \\
\hline s1 & $9,6 \pm 2,1$ & $9,8 \pm 3,1$ & $6,2 \pm 0,9^{a}$ & $3,1 \pm 3,7^{a b}$ & $7,3 \pm 2,8$ \\
\hline S2 & $4,9 \pm 3,1$ & $6,7 \pm 0,6$ & $3,5 \pm 2,8$ & $-0,2 \pm 3,0^{a b}$ & $5,1 \pm 0,3$ \\
\hline Total & $7,3 \pm 3,5$ & $8,2 \pm 2,8$ & $4,8 \pm 2,3^{a}$ & $1,4 \pm 3,5^{a b}$ & $6,2 \pm 2,1$ \\
\hline
\end{tabular}

a difere significantemente ( $p<0,05)$ em relação ao controle $(0 \%)$ - (ANOVA, seguida de Dunnett).

${ }^{b}$ difere significantemente $(p<0,05)$ em relação ao PF (Teste "t" Student). 


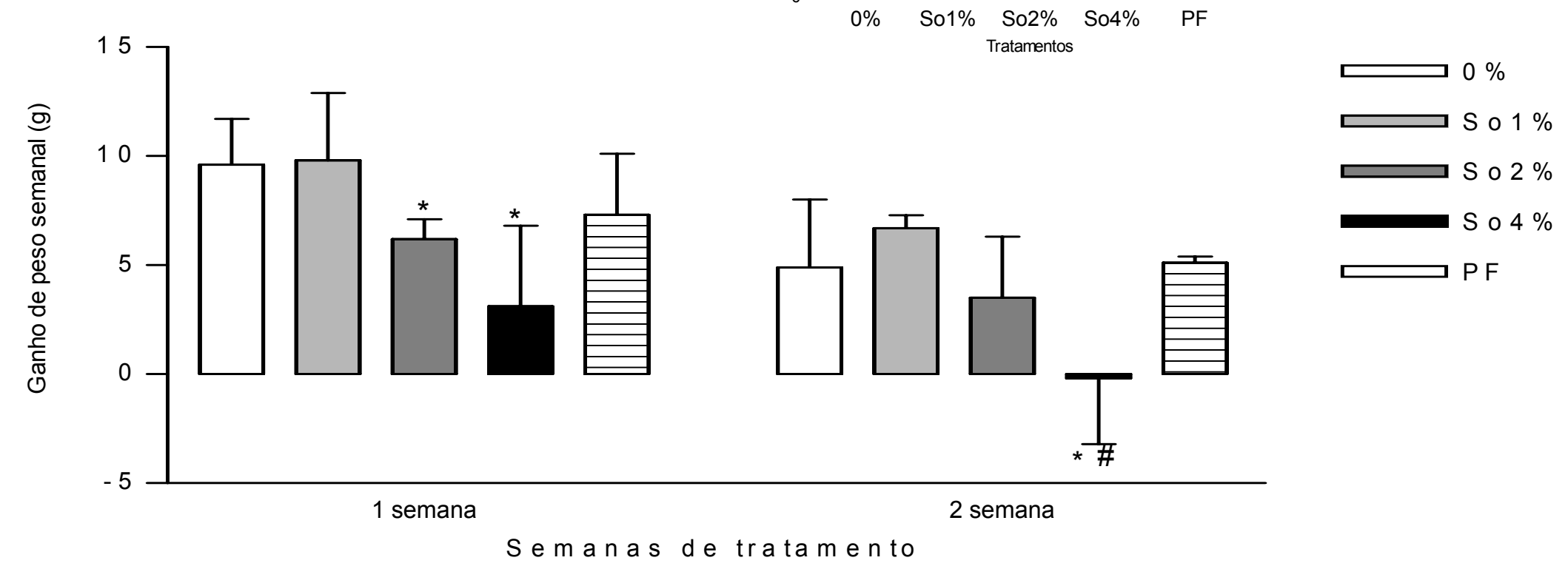

* difere significantemente $(p<0,05)$ em relação controle $(0 \%)$ - (ANOVA, seguida de Dunnett).

\# difere significantemente $(p<0,05)$ em relação ao PF (Teste " $t$ " Student).

Figura 5 - Peso semanal e total (em g), de ratos recém-desmamados tratados durante 14 dias com diferentes concentrações $(0 \%, 1 \%, 2 \%$ e $4 \%)$ de sementes de S. occidentalis, na ração e seu grupo peer-feeding (PF). Foram utilizados 10 animais por grupo. São apresentados as médias e os respectivos desvios padrões 
Tabela 4 - Número médio de eritrócitos $\left(x 10^{6} / \mathrm{mm}^{3}\right)$ e leucócitos $\left(\times 10^{6} / \mathrm{mm}^{3}\right)$ e os valores médios do hematócrito - HCT $(\%)$ e hemoglobina - $\mathrm{Hb}(\mathrm{g} / \mathrm{dL})$, volume corpuscular médio - VCM $\left(\mu^{3}\right)$, hemoglobina corpuscular média - HCM $(\mu \mu \mathrm{g})$ e concentração de hemoglobina corpuscular média - CHCM (\%), de ratos recém-desmamados tratados durante 14 dias com diferentes concentrações $(0 \%, 1 \%, 2 \%$ e $4 \%)$ de sementes de $S$. occidentalis, na ração e seu grupo peer-feeding (PF). Foram utilizados 10 animais por grupo. São apresentados as médias e os respectivos desvios padrões

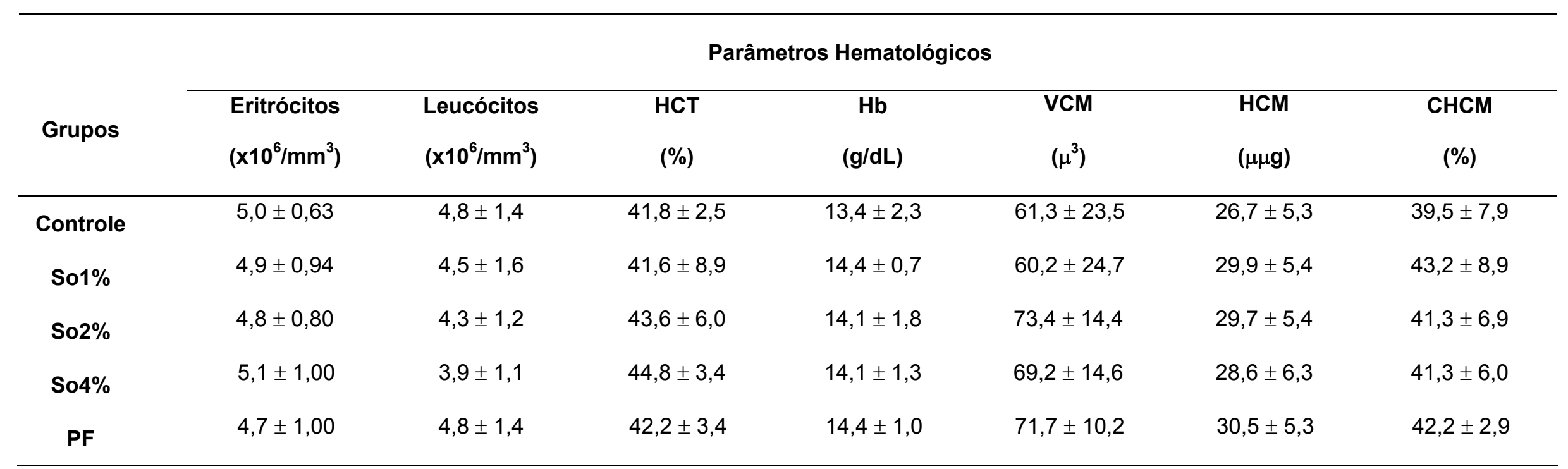


Tabela 5 - Média do número de linfócitos (em \%), neutrófilos segmentados (em\%), eosinófilos (em \%), bastonete (em \%) e monócitos (em \%), de ratos recém-desmamados tratados durante 14 dias com diferentes concentrações $(0 \%, 1 \%, 2 \%$ e $4 \%)$ de sementes de S. occidentalis, na ração e seu grupo peer-feeding (PF). Foram utilizados 10 animais por grupo. São apresentados as médias e os respectivos desvios padrões

\begin{tabular}{|c|c|c|c|c|c|}
\hline \multirow[b]{2}{*}{ Grupos } & \multicolumn{5}{|c|}{ Parâmetros Hematológicos } \\
\hline & Linfócitos (\%) & Neutrófilos (\%) & Eosinófilos (\%) & Bastonetes (\%) & Monócitos (\%) \\
\hline Controle & $68,0 \pm 0,9$ & $25,0 \pm 0,6$ & $1,0 \pm 0,1$ & $2,0 \pm 0,2$ & $4,0 \pm 0,5$ \\
\hline So1\% & $69,0 \pm 1,0$ & $25,0 \pm 0,6$ & $1,0 \pm 0,1$ & $2,0 \pm 0,4$ & $3,0 \pm 0,4$ \\
\hline So2\% & $70,0 \pm 1,0$ & $24,0 \pm 0,8$ & $1,0 \pm 0,1$ & $2,0 \pm 0,6$ & $3,0 \pm 0,4$ \\
\hline So4\% & $68,0 \pm 0,5$ & $25,0 \pm 0,5$ & $1,0 \pm 0,1$ & $3,0 \pm 0,7$ & $3,0 \pm 0,3$ \\
\hline PF & $67,0 \pm 1,0$ & $26,0 \pm 0,7$ & $1,0 \pm 0,1$ & $2,0 \pm 0,5$ & $4,0 \pm 1,0$ \\
\hline
\end{tabular}


Tabela 6 - Peso relativo do baço e timo ( $\mathrm{g} / 100 \mathrm{~g} \mathrm{pv}$ ), de ratos recém-desmamados tratados durante 14 dias com diferentes concentrações $(0 \%, 1 \%, 2 \%$ e $4 \%)$ de sementes de $S$. occidentalis, na ração e seu grupo peer-feeding (PF). Foram utilizados 10 animais por grupo. São apresentados as médias e os respectivos desvios padrões

\begin{tabular}{|c|c|c|c|c|c|}
\hline \multirow{2}{*}{ órgãos } & \multicolumn{5}{|c|}{ Senna occidentalis (\%) } \\
\hline & 0 & 1 & 2 & 4 & PF \\
\hline baço & $0,250 \pm 0,028$ & $0,269 \pm 0,050$ & $0,318 \pm 0,048^{a}$ & $0,337 \pm 0,044^{a b}$ & $0,224 \pm 0,046$ \\
\hline timo & $0,311 \pm 0,063$ & $0,276 \pm 0,026$ & $0,291 \pm 0,047$ & $0,174 \pm 0,044^{a}$ & $0,207 \pm 0,042^{a}$ \\
\hline
\end{tabular}

\footnotetext{
a difere significantemente $(p<0,05)$ em relação ao controle $(0 \%)$ - (ANOVA, seguida de Dunnett).
}

${ }^{b}$ difere significantemente $(p<0,05)$ em relação ao PF (Teste " $t$ " Student). 

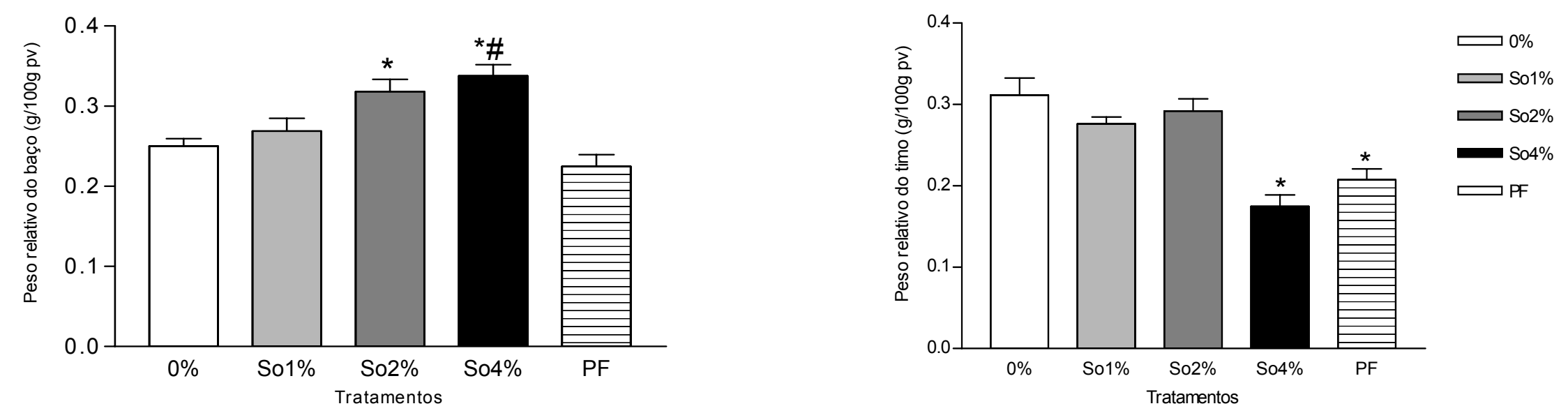

* difere significantemente $(p<0,05)$ em relação controle $(0 \%)$ - (ANOVA, seguida de Dunnett).

${ }^{\#}$ difere significantemente $(\mathrm{p}<0,05)$ do grupo PF (Teste " $\mathrm{t}$ " Student).

Figura 6 - Peso relativo do baço e do timo ( $/ 100 \mathrm{~g}$ pv), de ratos recém-desmamados tratados durante 14 dias com diferentes concentrações $(0 \%, 1 \%, 2 \%$ e $4 \%)$ de sementes de S. occidentalis, na ração e seu grupo peer-feeding (PF). Foram utilizados 10 animais por grupo. São apresentados as médias e os respectivos desvios padrões 
Tabela 7 - Celularidade do baço e da medula óssea (x 10\% /cel), de ratos recém-desmamados tratados durante 14 dias com diferentes concentrações $(0 \%, 1 \%, 2 \%$ e $4 \%)$ de sementes de $S$. occidentalis, na ração e seu grupo peer-feeding (PF).

Foram utilizados 10 animais por grupo. São apresentados as médias e os respectivos desvios padrões

\begin{tabular}{|c|c|c|c|c|c|}
\hline \multirow{2}{*}{ Órgão } & \multicolumn{5}{|c|}{ Senna occidentalis (\%) } \\
\hline & 0 & 1 & 2 & 4 & PF \\
\hline
\end{tabular}

a difere significantemente $(p<0,05)$ em relação ao controle $(0 \%)$ - (ANOVA, seguida de Dunnett).

${ }^{b}$ difere significantemente $(p<0,05)$ em relação ao PF (Teste "t" Student). 


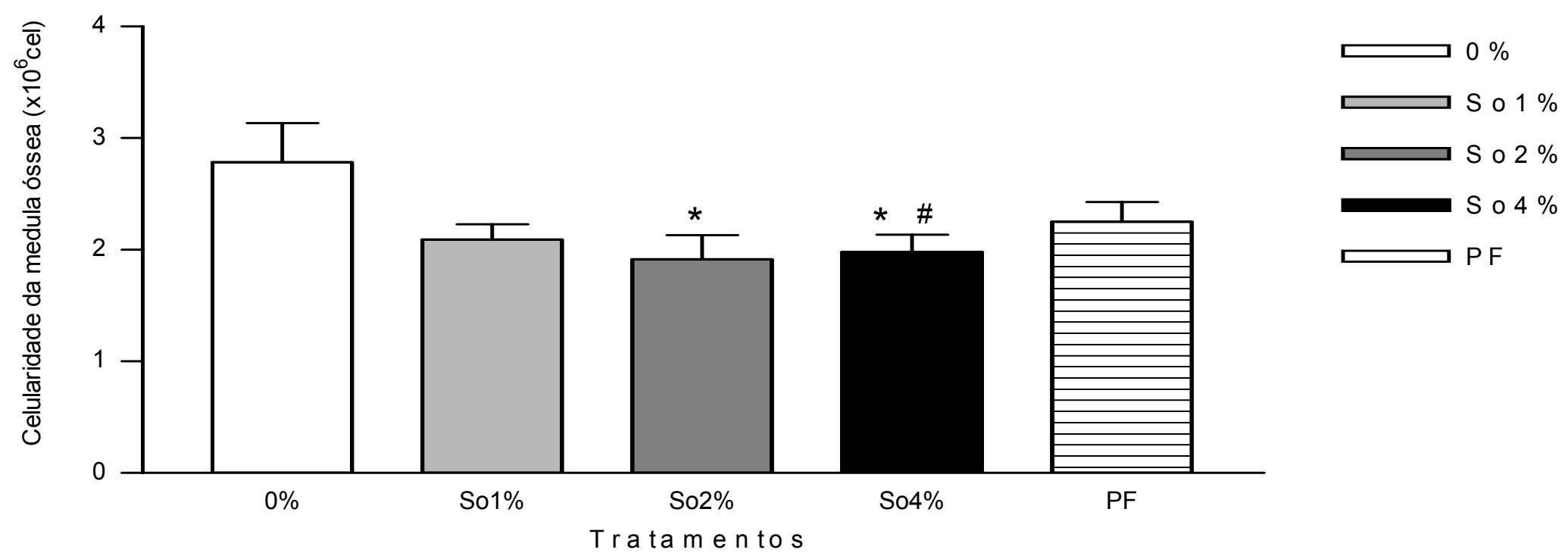

* difere significantemente $(p<0,05)$ em relação controle $(0 \%)$ - (ANOVA, seguida de Dunnett).

\# difere significantemente $(p<0,05)$ do grupo PF (Teste "t" Student).

Figura 7 - Celularidade da medula óssea (x 10\% /cel), de ratos recém-desmamados tratados durante 14 dias com diferentes concentrações $(0 \%, 1 \%, 2 \%$ e $4 \%)$ de sementes de $S$. occidentalis, na ração e seu grupo peer-feeding (PF). Foram utilizados 10 animais por grupo. São apresentados as médias e os respectivos desvios padrões 

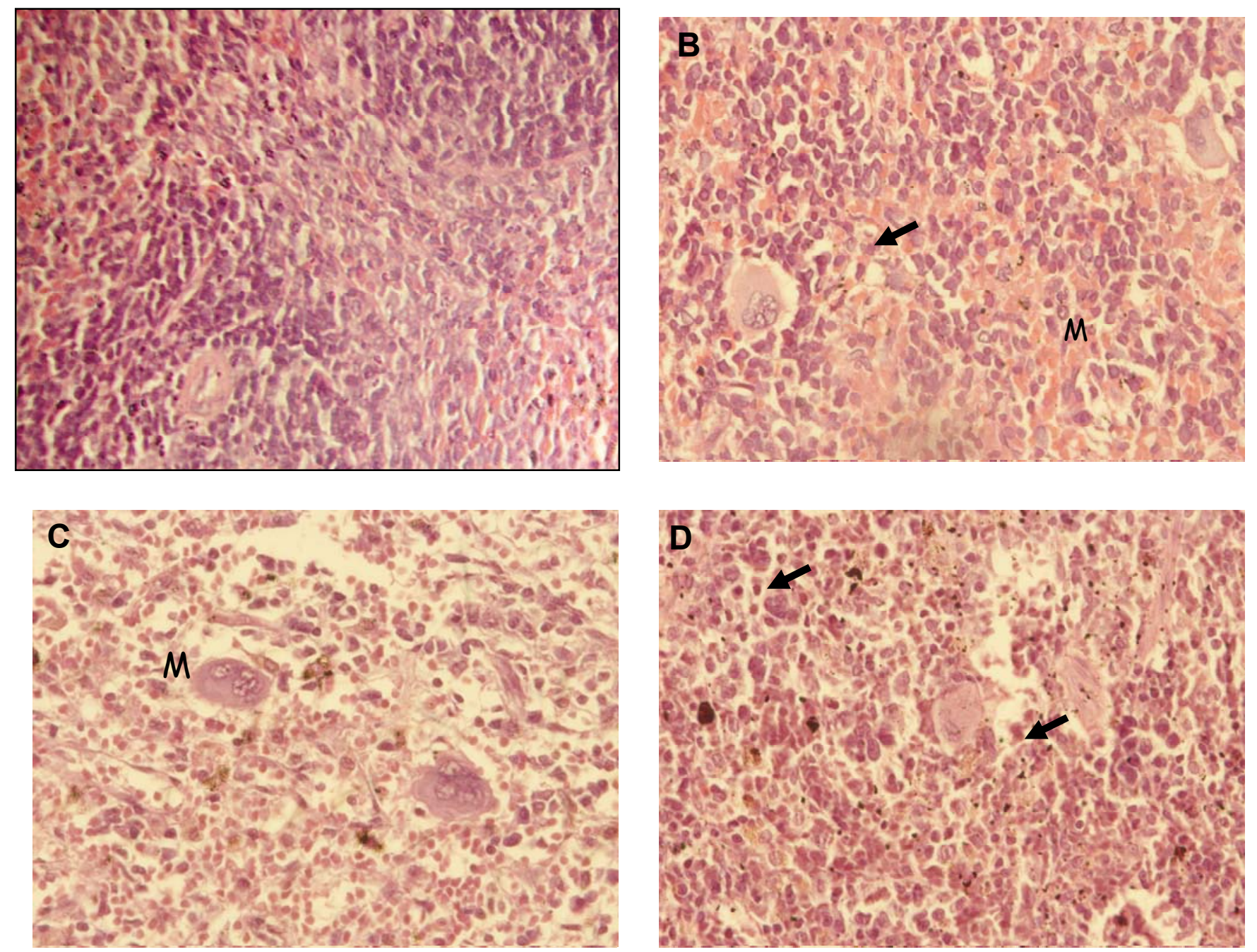

Figura 8 - Fotomicrográfia do baço de ratos recém-desmamados tratados durante 14 dias com sementes de S. occidentalis na ração. A. Integridade do parênquima esplênico com linfonodos bem delimitados, animal controle. B. Aumento do tamanho dos folículos linfóides e presença de megacariócitos (M), nos ratos do grupo So4\% (seta). C. Megacariócitos (M) visíveis com núcleo multilobulado e nucléolos proeminentes (seta), nos ratos do grupo So4\%. D. Progenitores eritróides em diferentes estágios de maturação (seta) nos ratos do grupo So4\%. (H.E. 40x) 


\subsection{EXPERIMENTO 2: AVALIAÇÃO DO BURST OXIDATIVO E DA FAGOCITOSE} DE NEUTRÓFILOS POR CITOMETRIA DE FLUXO, DE RATOS RECÉMDESMAMADOS TRATADOS COM DIFERENTES CONCENTRAÇÕES DE S. occidentalis NA RAÇÃO

A tabela 8 mostra o consumo médio e total de ração pelos ratos durante o experimento. Assim, a análise estatística realizada mostrou não haver nenhuma diferença significante entre o consumo médio e total de ração, pelos animais tratados com a planta, quando comparado aos ratos do grupo controle. Sendo que o consumo de ração dos animais do grupo PF foi idêntico àquele dos ratos submetidos à administração de ração contendo 4\% de sementes de S. occidentalis (dados não apresentados).

Em relação ao peso médio destes animais (Tabela 9 e Figura 9), as análises de variância realizadas revelaram haver diferença significante entre os grupos nos $12^{\circ}$ e $14^{\circ}$ dias do experimento $\left(F_{12}=2,280 ; F_{14}=4,348 ; d f=4 / 44\right.$, respectivamente, $p<0,05)$, quando comparado aos resultados obtidos dos animais pertencentes ao grupo controle. A aplicação do teste de Dunnett mostrou redução significante $(p<0,05)$ deste parâmetro no $12^{\circ}$ dia de tratamento pelos animais pertencentes ao grupo So4\%, em relação aos animais do grupo controle. Este mesmo teste apontou ainda, diminuição significante $(p<0,05)$ no ganho de peso, daqueles ratos pertencentes aos grupos So $2 \%$, So $4 \%$ e PF no $14^{\circ}$ dia do experimento, em relação aos animais do grupo controle.

Os ganhos de peso médios semanais e totais destes ratos são apresentados na tabela 10 e ilustrados na figura 10. A análise de variância realizada revelou haver 
diferença significante entre os grupos na $1^{\circ}$ e $2^{\circ}$ semanas $\left(F_{1}=5,884 ; F_{2}=2,491\right.$; $d f=4 / 45$, respectivamente, $p<0,05)$, bem como, no período total $(F=2,675 ; d f=4 / 45$, respectivamente, $p<0,05)$ do experimento. A aplicação do teste de Dunnett mostrou diminuição significante $(p<0,05)$ no ganho de peso semanal dos animais tratados com So1\%, So2\% e So $4 \%$ na primeira semana de avaliação. Este mesmo teste apontou, ainda, redução significante $(p<0,05)$ de peso na $2^{\circ}$ semana de tratamento apenas nos animais So4\%. Na avaliação do ganho de peso total, apenas os animais pertencentes ao grupo So4\% apresentaram diminuição deste parâmetro quando comparados aos animais do grupo controle.

Em relação às observações clínicas, os seguintes sinais e sintomas, foram observados: letargia, abatimento, prostração, pêlos arrepiados e fezes amolecidas, a partir da segunda semana de tratamento em todos os animais pertencentes ao grupo So4\%.

A tabela 11 mostra e a figura 11, a avaliação do burst oxidativo e da fagocitose de neutrófilos, por citometria de fluxo, de ratos recém-desmamados tratados com diferentes concentrações de $S$. occidentalis na ração. A análise de variância realizada revelou haver diferença significante $(p<0,05)$ entre os grupos, no burst basal $(F=4,033 ; d f=4 / 41)$ e na porcentagem de fagocitose de neutrófilos $(F=4,054 ; d f=4 / 44) . A$ aplicação do teste de Dunnett mostrou haver redução significante $(p<0,05)$ no burst oxidativo basal de neutrófilos, naqueles animais pertencentes ao grupo So4\%, em relação aos ratos pertencentes ao grupo controle. Este mesmo teste apontou ainda, diminuição significante $(p<0,05)$ na porcentagem de fagocitose, nos animais pertencentes aos grupos So1\%, So $2 \%$, So $4 \%$ e PF, quando comparados aos animais pertencentes ao grupo controle. 
Tabela 8 - Consumo médio e total de ração (em g) pelos ratos recém-desmamados tratados durante 14 dias com diferentes concentrações $(0 \%, 1 \%, 2 \%$ e $4 \%)$ de sementes de S. occidentalis, na ração. Foram utilizados 10 animais por grupo. São apresentados as médias e os respectivos desvios padrões

\begin{tabular}{ccccc}
\hline \multirow{2}{*}{ Dias de tratamento } & \multicolumn{4}{c}{ Senna occidentalis (\%) } \\
\cline { 2 - 5 } & $\mathbf{0}$ & $\mathbf{1}$ & $\mathbf{2}$ & $\mathbf{4}$ \\
\hline $\mathbf{2}^{\mathbf{0}}$ & $30,0 \pm 9,7$ & $30,1 \pm 9,1$ & $29,0 \pm 5,0$ & $26,8 \pm 8,8$ \\
$\mathbf{4}^{\mathbf{0}}$ & $19,9 \pm 6,5$ & $22,9 \pm 6,2$ & $22,1 \pm 3,9$ & $19,3 \pm 5,8$ \\
$\mathbf{6}^{\mathbf{0}}$ & $26,4 \pm 3,4$ & $24,6 \pm 4,1$ & $28,8 \pm 2,5$ & $26,9 \pm 6,7$ \\
$\mathbf{8}^{\mathbf{0}}$ & $20,5 \pm 4,9$ & $21,6 \pm 5,0$ & $23,5 \pm 6,0$ & $23,0 \pm 10,5$ \\
$\mathbf{1 0}^{\mathbf{0}}$ & $38,3 \pm 6,8$ & $36,7 \pm 6,3$ & $35,3 \pm 7,4$ & $36,7 \pm 9,1$ \\
$\mathbf{1 2}^{\mathbf{0}}$ & $26,4 \pm 2,1$ & $26,8 \pm 4,3$ & $25,7 \pm 3,9$ & $25,5 \pm 7,1$ \\
$\mathbf{1 4}^{\mathbf{0}}$ & $20,2 \pm 2,5$ & $20,3 \pm 2,2$ & $21,7 \pm 4,3$ & $21,9 \pm 7,3$ \\
Total & $27,3 \pm 8,2$ & $28,2 \pm 6,8$ & $28,8 \pm 7,1$ & $26,4 \pm 7,9$
\end{tabular}


Tabela 9 - Peso médio (em g), de ratos recém-desmamados tratados durante 14 dias com diferentes concentrações (0\%, $1 \%, 2 \%$ e $4 \%$ ) de sementes de S. occidentalis, na ração e seu grupo peer-feeding (PF). Foram utilizados 10 animais por grupo. São apresentados as médias e os respectivos desvios padrões

\begin{tabular}{|c|c|c|c|c|c|}
\hline \multirow{2}{*}{ Dias de tratamento } & \multicolumn{5}{|c|}{ Senna occidentalis (\%) } \\
\hline & 0 & 1 & 2 & 4 & PF \\
\hline $2^{\circ}$ & $96,8 \pm 12,6$ & $101,0 \pm 12,1$ & $84,4 \pm 13,9$ & $88,5 \pm 14,7$ & $93,0 \pm 19,2$ \\
\hline $4^{\circ}$ & $105,9 \pm 13,9$ & $106,4 \pm 12,4$ & $91,2 \pm 13,9$ & $95,2 \pm 15,5$ & $101,9 \pm 20,6$ \\
\hline $6^{\circ}$ & $115,2 \pm 14,9$ & $112,6 \pm 12,8$ & $97,2 \pm 13,9$ & $105,3 \pm 15,0$ & $110,5 \pm 22,2$ \\
\hline $8^{\circ}$ & $124,6 \pm 15,2$ & $121,0 \pm 11,0$ & $107,5 \pm 13,2$ & $114,1 \pm 17,3$ & $119,1 \pm 20,8$ \\
\hline $10^{\circ}$ & $127,9 \pm 22,5$ & $135,4 \pm 16,1$ & $119,0 \pm 11,2$ & $123,7 \pm 21,8$ & $133,1 \pm 15,1$ \\
\hline $12^{\circ}$ & $145,4 \pm 15,3$ & $140,2 \pm 15,7$ & $131,7 \pm 11,9$ & $127,5 \pm 6,8^{a}$ & $133,2 \pm 21,6$ \\
\hline $14^{\circ}$ & $158,6 \pm 16,1$ & $144,3 \pm 16,8$ & $133,5 \pm 5,8^{a}$ & $136,8 \pm 11,3^{a}$ & $136,6 \pm 21,6^{a}$ \\
\hline
\end{tabular}

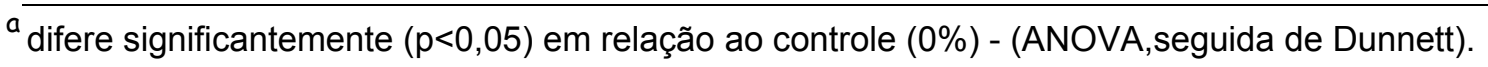




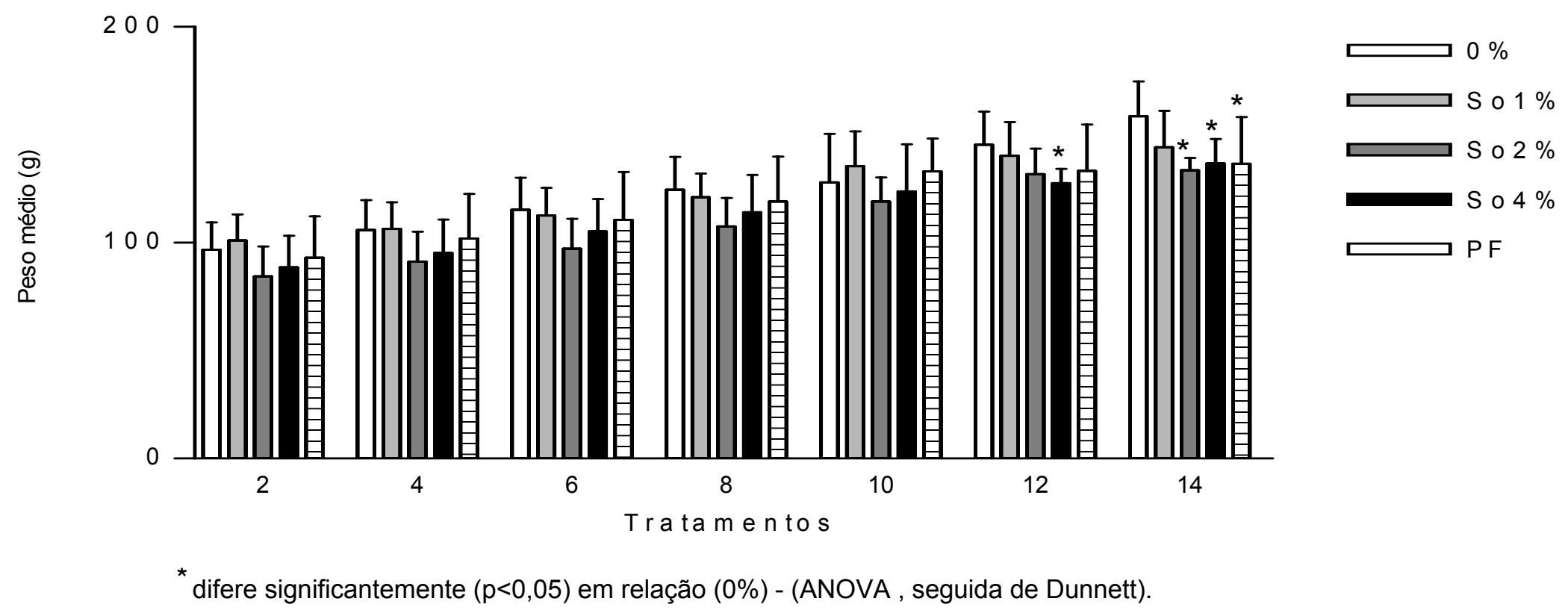

Figura 9 - Peso médio (em g), de ratos recém-desmamados tratados durante 14 dias com diferentes concentrações $(0 \%$, $1 \%$, $2 \%$ e $4 \%$ ) de sementes de $S$. occidentalis, na ração e seu grupo peer-feeding (PF). Foram utilizados 10 animais por grupo. São apresentados as médias e os respectivos desvios padrões 
Tabela 10 - Peso semanal e total (em g), de ratos recém-desmamados tratados durante 14 dias com diferentes concentrações $(0 \%, 1 \%, 2 \%$ e $4 \%)$ de sementes de S. occidentalis, na ração e seu grupo peer-feeding (PF). Foram utilizados 10 animais por grupo. São apresentados as médias e os respectivos desvios padrões

\begin{tabular}{|c|c|c|c|c|c|}
\hline \multirow{2}{*}{$\begin{array}{l}\text { Semanas de } \\
\text { tratamento }\end{array}$} & \multicolumn{5}{|c|}{ Senna occidentalis (\%) } \\
\hline & 0 & 1 & 2 & 4 & PF \\
\hline s1 & $9,2 \pm 0,15$ & $6,3 \pm 1,4^{a}$ & $6,6 \pm 2,7^{a}$ & $6,5 \pm 2,6^{a}$ & $8,7 \pm 0,23$ \\
\hline S2 & $10,0 \pm 3,3$ & $7,9 \pm 4,7$ & $9,9 \pm 3,3$ & $5,1 \pm 3,1^{a}$ & $8,1 \pm 5,1$ \\
\hline Total & $9,6 \pm 1,7$ & $7,1 \pm 3,0$ & $8,2 \pm 3,0$ & $5,8 \pm 2,8^{a}$ & $8,4 \pm 2,6$ \\
\hline
\end{tabular}

a difere significantemente $(p<0,05)$ em relação ao controle $(0 \%)$ - (ANOVA, seguida de Dunnett). 

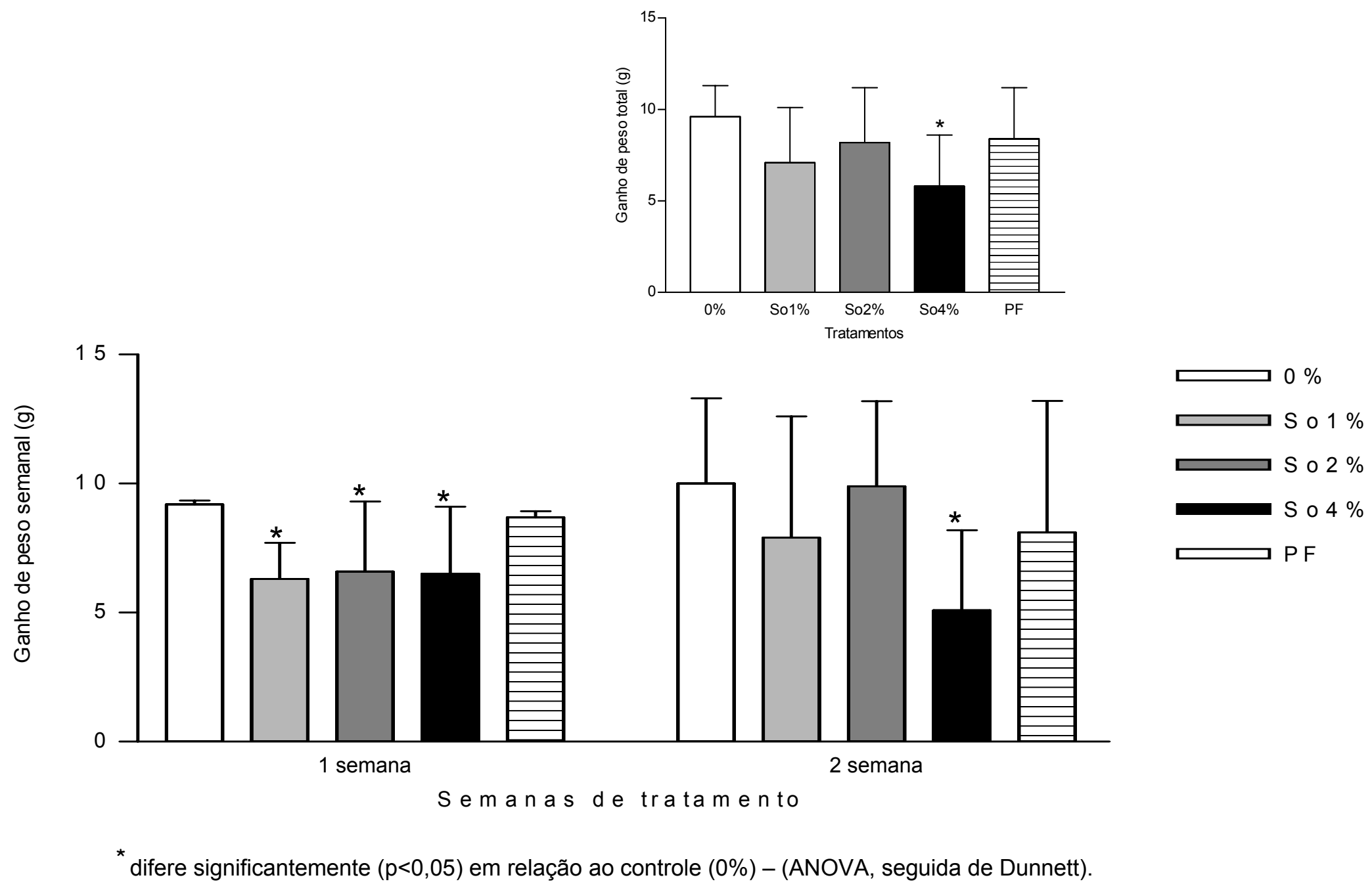

Figura 10 - Peso semanal e total (em g), de ratos recém-desmamados tratados durante 14 dias com diferentes concentrações $(0 \%, 1 \%, 2 \%$ e $4 \%)$ de sementes de S. occidentalis, na ração e seu grupo peer-feeding (PF). Foram utilizados 10 animais por grupo. São apresentados as médias e os respectivos desvios padrões 
Tabela 11 - Avaliação do burst oxidativo e da fagocitose de neutrófilos, de ratos recém-desmamados tratados durante 14 dias com diferentes concentrações $(0 \%, 1 \%, 2 \%$ e $4 \%)$ de sementes de S. occidentalis, na ração e seu grupo peerfeeding (PF). Foram utilizados 10 animais por grupo. São apresentados as médias e os respectivos desvios padrões

\begin{tabular}{|c|c|c|c|c|c|}
\hline \multirow{2}{*}{ Parâmetros } & \multicolumn{5}{|c|}{ Senna occidentalis (\%) } \\
\hline & 0 & 1 & 2 & 4 & PF \\
\hline Burst basal & $72,7 \pm 24,1$ & $72,8 \pm 13,2$ & $76,7 \pm 17,8$ & $41,9 \pm 25,8^{a}$ & $55,8 \pm 24,9$ \\
\hline Burst SAPI & $89,5 \pm 8,4$ & $92,3 \pm 18,9$ & $86,4 \pm 12,6$ & $92,3 \pm 4,4$ & $90,6 \pm 7,2$ \\
\hline Burst PMA & $456,5 \pm 143,4$ & $372,2 \pm 169,3$ & $400,0 \pm 111,6$ & $429,3 \pm 124,5$ & $454,6 \pm 140,3$ \\
\hline Burst DCFH & $88,6 \pm 6,4$ & $78,1 \pm 19,3$ & $76,7 \pm 17,8$ & $83,1 \pm 11,8$ & $88,5 \pm 8,7$ \\
\hline$\%$ Fagocitose ${ }^{c 1}$ & $59,8 \pm 21,9$ & $41,8 \pm 13,2^{a}$ & $37,4 \pm 15,7^{a}$ & $27,0 \pm 14,9^{a}$ & $34,6 \pm 29,2^{a}$ \\
\hline $\begin{array}{l}\text { Intensidade } \\
\text { fagocitose }\end{array}$ & $72,3 \pm 23,8$ & $65,4 \pm 17,5$ & $61,5 \pm 13,7$ & $66,4 \pm 12,0$ & $67,4 \pm 16,9$ \\
\hline
\end{tabular}

Os dados representam a intensidade média de fluorescência (médias e os respectivos desvios padrões), correspondentes ao gate da população de neutrófilos sangüíneos.

${ }^{a}$ difere significantemente $(p<0,05)$ em relação ao controle $(0 \%)$ - (ANOVA,seguida de Dunnett).

${ }^{c 1}$ porcentagem de neutrófilos que fagocitaram partículas de SAPI.

c2 quantidade de bactérias, que foram fagocitadas pela população de neutrófilos. Expressas pela média geométrica da intensidade de fluorescência da população de neutrófilos. 

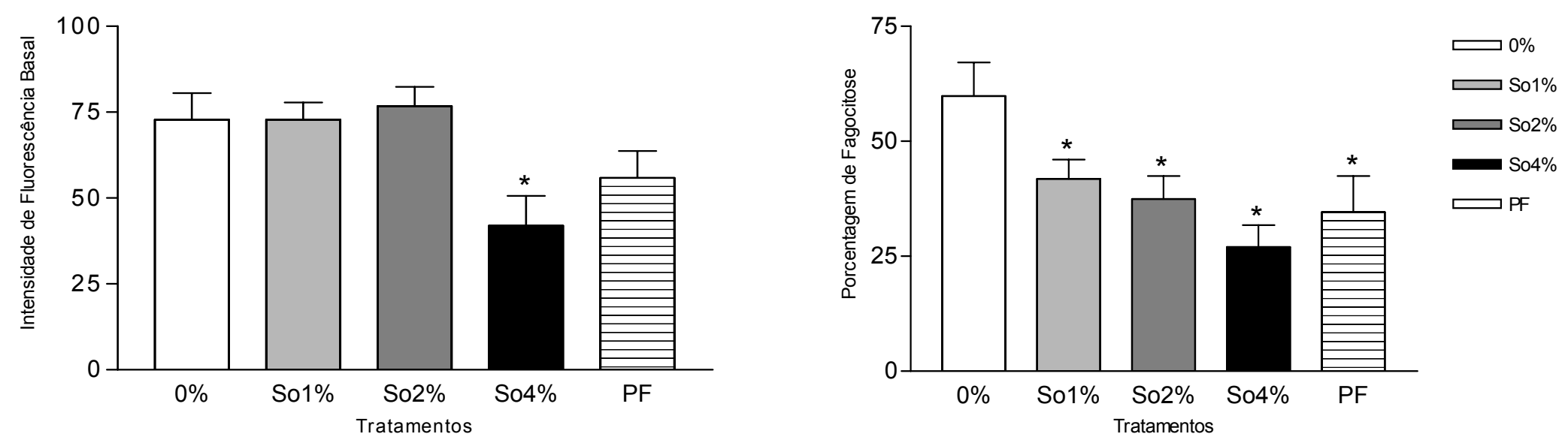

* difere significantemente $(p<0,05)$ em relação ao controle $(0 \%)$ - (ANOVA, seguida de Dunnett).

Figura 11 - Avaliação do burst oxidativo e da fagocitose de neutrófilos, de ratos recém-desmamados tratados durante 14 dias com diferentes concentrações $(0 \%, 1 \%, 2 \%$ e $4 \%)$ de sementes de S. occidentalis, na ração e seu grupo peer-feeding (PF). Foram utilizados 10 animais por grupo. São apresentados as médias e os respectivos desvios padrões 


\subsection{EXPERIMENTO 3: AVALIAÇÃO DA HIPERSENSIBILIDADE DO TIPO} TARDIA A SORO ALBUMINA BOVINA (BSA), DE RATOS RECÉMDESMAMADOS TRATADOS COM DIFERENTES CONCENTRAÇÕES DE SEMENTES DE Senna occidentalis NA RAÇÃO DURANTE 14 DIAS

A tabela 12 mostra e a figura 12 ilustra o consumo médio e total de ração pelos ratos tratados com diferentes concentrações de S. occidentalis na ração. Assim, a análise estatística realizada revelou haver diferença significante entre os grupos apenas no $14^{\circ}$ dia do experimento $\left(F_{14}=4,491 ; d f=3 / 39\right.$, respectivamente, $p<0,05)$, bem como no período total $(F=2,552$ e $d f=3 / 39)$, quando comparado aos resultados obtidos dos animais pertencentes ao grupo controle, sendo que o consumo dos animais do grupo peer-feeding (PF) foi idêntico àquele dos ratos submetidos à administração de ração contendo $4 \%$ de sementes de S. occidentalis (dados não apresentados). A aplicação do teste de Dunnett apontou diminuição significante $(p<0,05)$ no consumo de ração daqueles animais pertencentes ao grupo So $4 \%$ apenas no $14^{\circ}$ dia de experimento quando comparados aos animais do grupo controle. Na avaliação do consumo total de ração, o teste de Dunnett revelou haver diminuição significante $(p<0,05)$ neste parâmetro apenas nos animais pertencentes ao grupo So4\%, quando comparado aos animais do grupo controle.

Em relação ao peso médio destes animais, as análises de variância realizadas revelaram haver diferença significante entre os grupos apenas no $14^{\circ}$ dia 
do experimento $\left(F_{14}=2,285 ; d f=4 / 45\right.$, respectivamente $\left.p<0,05\right)$, dados apresentados na tabela 13 e ilustrados pela figura 13.

O ganho de peso médio semanal e total destes ratos é apresentado na tabela 14 e ilustrado pela figura 14. Assim, a análise de variância realizada revelou haver diferença significante $(p<0,05)$ entre os grupos na $2^{\circ}$ semana $\left(F_{2}=2,377 ; d f=4 / 45\right)$, do experimento. A aplicação do teste de Dunnett mostrou diminuição significante $(p<0,05)$ no ganho de peso semanal dos animais tratados com So4\%, em relação aos animais do grupo controle.

Em relação às observações clínicas, os seguintes sinais e sintomas, foram observados: letargia, abatimento, prostração, pêlos arrepiados e fezes amolecidas, a partir da segunda semana de tratamento em todos os animais pertencentes ao grupo So4\%.

A resposta celular adaptativa em ratos recém-desmamados tratados durante 14 dias com sementes de $S$. occidentalis na ração, foi avaliada por meio do teste de hipersensibilidade tipo tardia (DTH), frente ao desafio com a Soro Albumina Bovina (BSA). A análise estatística revelou não haver diferença significante $(p>0,05)$ na evolução do edema induzido pela inoculação de $0,1 \mathrm{~mL}$ de BSA no coxim plantar dos ratos tratados com as diferentes concentrações da planta, quando comparados aos animais pertencentes ao grupo controle, nos tempos 0, 4 e 24 horas de avaliação (Tabela 15). 
Tabela 12 - Consumo médio e total de ração $(\mathrm{g})$ pelos ratos recém-desmamados tratados durante 14 dias com diferentes concentrações $(0 \%, 1 \%, 2 \%$ e $4 \%)$ de sementes de $S$. occidentalis, na ração. Foram utilizados 10 animais por grupo. São apresentados as médias e os respectivos desvios padrões

\begin{tabular}{ccccc}
\hline Dias de tratamento & \multicolumn{4}{c}{ Senna occidentalis (\%) } \\
\cline { 2 - 5 } & $\mathbf{0}$ & $\mathbf{1}$ & $\mathbf{2}$ & $\mathbf{4}$ \\
\hline $\mathbf{2}^{\mathbf{0}}$ & $33,9 \pm 9,0$ & $30,8 \pm 3,4$ & $30,9 \pm 4,1$ & $33,0 \pm 2,6$ \\
$\mathbf{4}^{\mathbf{0}}$ & $37,8 \pm 8,2$ & $38,1 \pm 3,2$ & $36,1 \pm 5,2$ & $33,9 \pm 1,8$ \\
$\mathbf{6}^{\mathbf{0}}$ & $30,0 \pm 9,2$ & $31,0 \pm 9,6$ & $22,5 \pm 11,1$ & $38,2 \pm 6,2$ \\
$\mathbf{8}^{\mathbf{0}}$ & $35,2 \pm 5,7$ & $37,5 \pm 4,7$ & $31,4 \pm 7,1$ & $34,5 \pm 4,5$ \\
$\mathbf{1 0}^{\mathbf{0}}$ & $38,8 \pm 4,0$ & $31,6 \pm 8,6$ & $31,3 \pm 9,3$ & $31,0 \pm 3,7$ \\
$\mathbf{1 2}^{\mathbf{0}}$ & $37,2 \pm 3,7$ & $33,7 \pm 7,3$ & $31,3 \pm 7,5$ & $28,6 \pm 6,6^{\mathrm{a}}$ \\
$\mathbf{1 4}^{\mathbf{0}}$ & $39,4 \pm 7,6$ & $31,6 \pm 5,9$ & $33,3 \pm 6,8$ & $27,6 \pm 4,1^{\mathrm{a}}$ \\
Total & $32,2 \pm 4,1$ & $30,4 \pm 3,2$ & $29,6 \pm 3,4$ & \\
\hline
\end{tabular}

\footnotetext{
${ }^{a}$ difere significantemente $(p<0,05)$ em relação ao controle - $(0 \%)$ - (ANOVA, seguida de Dunnett).
} 

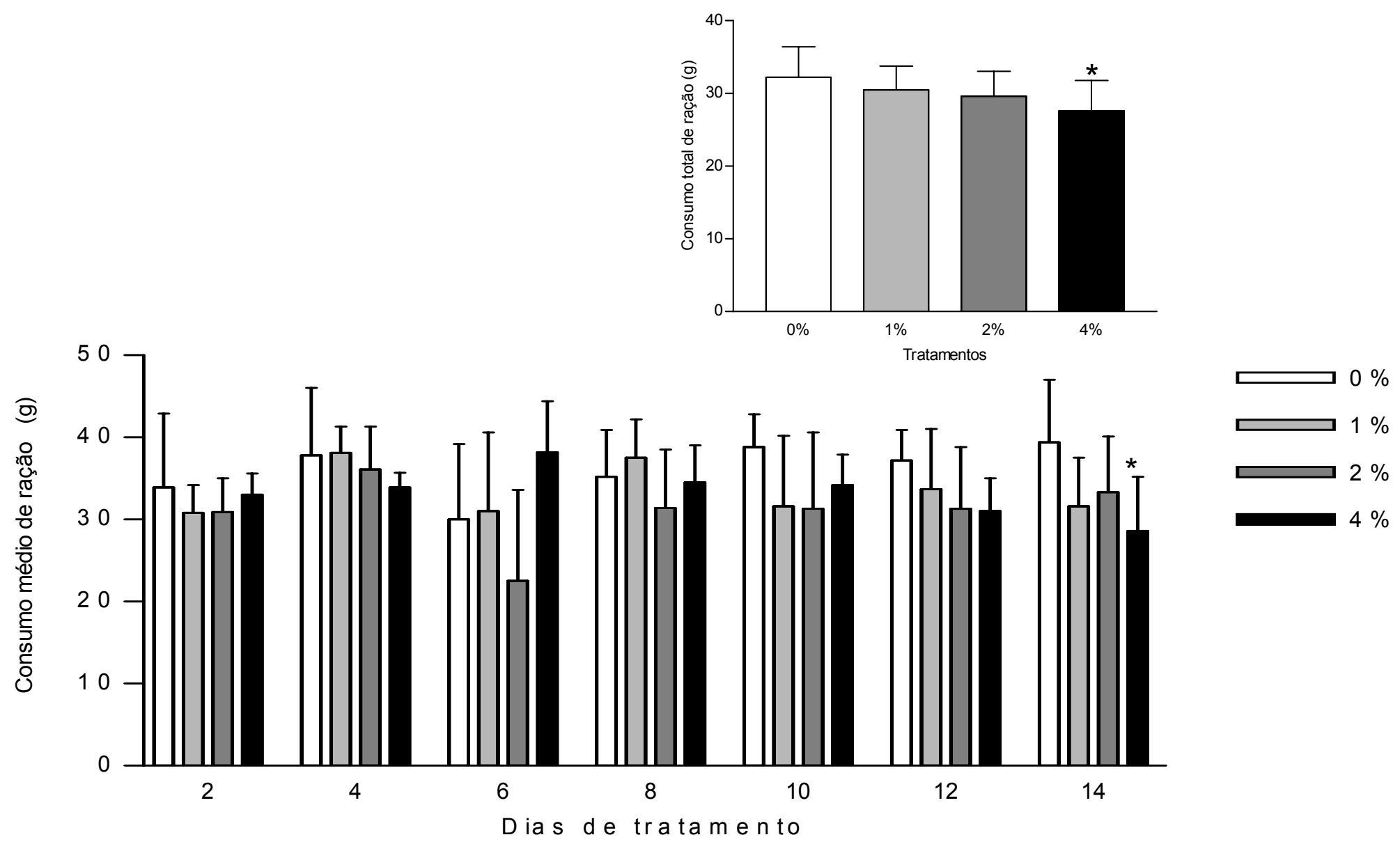

* difere significantemente $(p<0,05)$ em relação ao controle $(0 \%)$ - (ANOVA, seguida de Dunnett).

Figura 12 - Consumo médio e total de ração $(\mathrm{g})$ pelos ratos recém-desmamados tratados durante 14 dias com diferentes concentrações $(0 \%, 1 \%, 2 \%$ e $4 \%)$ de sementes de S. occidentalis, na ração. Foram utilizados 10 animais por grupo. São apresentados as médias e os respectivos desvios padrões 
Tabela 13 - Peso médio $(\mathrm{g})$, de ratos recém-desmamados tratados durante 14 dias com diferentes concentrações $(0 \%, 1 \%$, $2 \%$ e $4 \%$ ) de sementes de S. occidentalis, na ração e seu grupo peer-feeding (PF). Foram utilizados 10 animais por grupo. São apresentados as médias e os respectivos desvios padrões

\begin{tabular}{cccccc}
\hline $\begin{array}{c}\text { Dias de } \\
\text { tratamento }\end{array}$ & $\mathbf{0}$ & $\mathbf{1}$ & $\mathbf{2}$ & $\mathbf{4}$ & $\mathbf{P F}$ \\
\hline $\mathbf{2}^{\mathbf{0}}$ & $94,7 \pm 4,7$ & $96,0 \pm 17,6$ & $89,4 \pm 12,3$ & $94,5 \pm 9,3$ & $90,5 \pm 5,3$ \\
$\mathbf{4}^{\mathbf{0}}$ & $103,8 \pm 6,3$ & $105,4 \pm 16,6$ & $99,0 \pm 13,8$ & $101,1 \pm 9,8$ & $100,3 \pm 6,0$ \\
$\mathbf{6}^{\mathbf{0}}$ & $116,5 \pm 6,1$ & $119,2 \pm 14,7$ & $112,7 \pm 13,6$ & $113,8 \pm 10,2$ & $113,8 \pm 6,9$ \\
$\mathbf{8}^{\mathbf{0}}$ & $122,2 \pm 6,0$ & $123,4 \pm 9,8$ & $117,5 \pm 12,6$ & $118,5 \pm 6,1$ & $121,5 \pm 9,4$ \\
$\mathbf{1 0}^{\mathbf{0}}$ & $129,5 \pm 7,5$ & $131,2 \pm 14,8$ & $123,3 \pm 13,6$ & $128,0 \pm 9,7$ & $126,9 \pm 8,7$ \\
$\mathbf{1 2}^{\mathbf{0}}$ & $146,4 \pm 7,9$ & $144,7 \pm 8,8$ & $140,7 \pm 16,6$ & $136,4 \pm 7,7$ & $143,2 \pm 9,3$ \\
$\mathbf{1 4}^{\circ}$ & $165,5 \pm 8,2$ & $163,7 \pm 9,1$ & $159,1 \pm 19,0$ & $150,7 \pm 11,6$ & $165,2 \pm 13,9$ \\
\end{tabular}

${ }^{a}$ difere significantemente $(p<0,05)$ em relação ao controle $(0 \%)$ - (ANOVA, seguida de Dunnett).

${ }^{b}$ difere significantemente $(p<0,05)$ do grupo PF (Teste "t" Student.). 


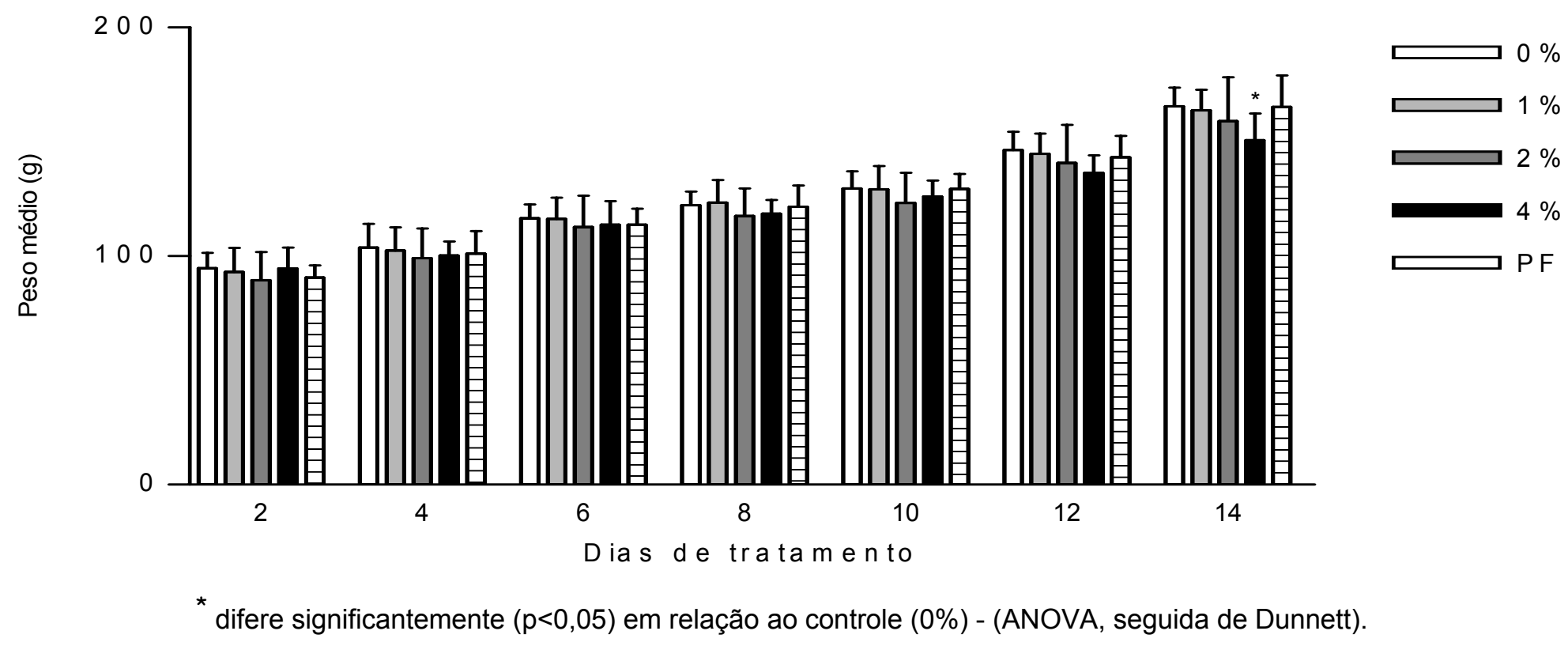

Figura 13 - Peso médio $(\mathrm{g})$, de ratos recém-desmamados tratados durante 14 dias com diferentes concentrações $(0 \%$, $1 \%, 2 \%$ e $4 \%$ ) de sementes de $S$. occidentalis, na ração e seu grupo peer-feeding (PF). Foram utilizados 10 animais por grupo. São apresentados as médias e os respectivos desvios padrões 
Tabela 14 - Peso semanal e total (g), de ratos recém-desmamados tratados durante 14 dias com diferentes concentrações $(0 \%, 1 \%, 2 \%$ e $4 \%)$ de sementes de $S$. occidentalis, na ração e seu grupo peer-feeding (PF). Foram utilizados 10 animais por grupo. São apresentados as médias e os respectivos desvios padrões

\begin{tabular}{cccccc}
\hline $\begin{array}{c}\text { Semanas de } \\
\text { tratamento }\end{array}$ & $\mathbf{0}$ & $\mathbf{1}$ & Senna occidentalis (\%) & $\mathbf{4}$ & $\mathbf{2}$ \\
\hline S1 & $4,5 \pm 1,7$ & $5,0 \pm 1,6$ & $4,6 \pm 2,2$ & $3,8 \pm 1,7$ & $5,1 \pm 1,4$ \\
S2 & $7,2 \pm 3,1$ & $5,7 \pm 2,5$ & $5,5 \pm 2,9$ & $4,1 \pm 0,9^{\mathrm{a}}$ & $5,0 \pm 1,5$ \\
Total & $5,9 \pm 2,6$ & $5,4 \pm 1,9$ & $5,1 \pm 1,3$ & $3,9 \pm 1,2$ & $5,1 \pm 1,3$ \\
\hline
\end{tabular}

$a^{a}$ difere significantemente $(p<0,05)$ em relação ao controle $(0 \%)$ - (ANOVA, seguida de Dunnett). 


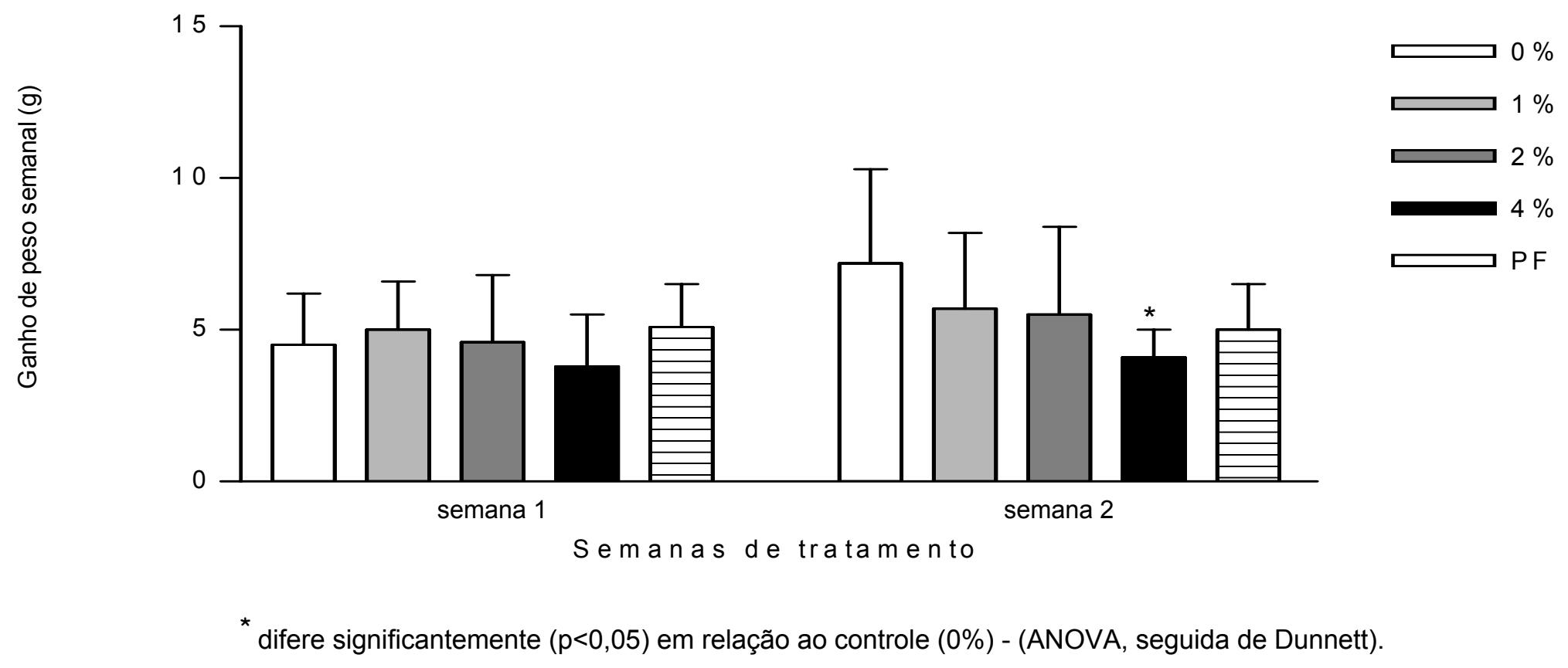

Figura 14 - Peso semanal e total (g), de ratos recém-desmamados tratados durante 14 dias com diferentes concentrações $(0 \%, 1 \%, 2 \%$ e $4 \%)$ de sementes de $S$. occidentalis, na ração e seu grupo peer-feeding (PF). Foram utilizados 10 animais por grupo. São apresentados as médias e os respectivos erros padrões 
Tabela 15 - Medida do edema induzido pela inoculação de $0,1 \mathrm{ml}$ de BSA no coxim plantar de ratos recém-desmamados durante 14 dias com diferentes concentrações $(0,1 \%, 2 \%$ e $4 \%)$ de sementes de $S$. occidentalis na ração e seu grupo peer-feeding (PF). Foram utilizados 10 animais por grupo. São apresentados as médias e os respectivos desvios padrões

\begin{tabular}{|c|c|c|c|c|c|}
\hline \multirow{2}{*}{ Tempos (horas) } & \multicolumn{5}{|c|}{ Senna occidentalis (\%) } \\
\hline & 0 & 1 & 2 & 4 & PF \\
\hline 0 & $0,16 \pm 0,08$ & $0,19 \pm 0,07$ & $0,19 \pm 0,07$ & $0,21 \pm 0,07$ & $0,20 \pm 0,06$ \\
\hline 4 & $0,33 \pm 0,2$ & $0,28 \pm 0,7$ & $0,43 \pm 0,2$ & $1,31 \pm 3,1$ & $0,37 \pm 0,2$ \\
\hline 24 & $0,18 \pm 0,10$ & $0,17 \pm 0,04$ & $0,20 \pm 0,06$ & $0,30 \pm 0,18$ & $0,18 \pm 0,06$ \\
\hline
\end{tabular}




\subsection{EXPERIMENTO 4: AVALIAÇÃO DO SISTEMA IMUNE E HEMATOPOIÉTICO, DE RATOS RECÉM-DESMAMADOS, TRATADOS COM 0 E 4\% DE SEMENTES DE S. occidentalis NA RAÇÃO DURANTE 28 DIAS E SEU GRUPO PEER-FEEDING.}

A tabela 16 mostra o consumo médio e total de ração pelos ratos durante o experimento. Assim, a análise estatística realizada revelou haver diferença significante $(p<0,05)$ entre os grupos no $14^{\circ}, 16^{\circ}, 18^{\circ}$ e $28^{\circ}$ dias do experimento. Sendo que o consumo de ração dos animais do grupo PF foi idêntico àquele dos ratos submetidos à administração de ração contendo $4 \%$ de sementes de S. occidentalis (dados não apresentados). A aplicação do teste "t" Student apontou diminuição significante $(p<0,05)$ no consumo de ração dos animais tratados com So4\%, quando comparado aos animais do grupo controle (Figura 15). Este mesmo teste apontou haver diferença $(p<0,05)$ no consumo total de ração dos animais tratados com a planta em relação aos ratos pertencentes ao grupo controle.

Em relação ao peso médio destes animais (Tabela 17 e Figura 16), as análises de variância realizadas revelaram haver diferença significante entre os grupos no $10^{\circ}, 12^{\circ}, 14^{\circ}, 16^{\circ}, 18^{\circ}, 20^{\circ}, 22^{\circ}, 24^{\circ}, 26^{\circ}$ e $28^{\circ}$ dias do experimento $\left(F_{10}=\right.$ 3,$283 ; F_{12}=5,837 ; F_{14}=9,277 ; F_{16}=15,21 ; F_{18}=18,88 ; F_{20}=25,43 ; F_{22}=30,18 ; F_{24}=$ 29,$34 ; \quad F_{26}=27,00 ; \quad F_{28}=24,22 ; \quad d f=2 / 27, \quad$ respectivamente, $\left.\quad p<0,05\right), \quad$ quando comparado aos resultados obtidos dos animais pertencentes ao grupo controle. A aplicação do teste de Dunnett mostrou redução significante $(p<0,05)$ deste parâmetro no $10^{\circ}, 12^{\circ}, 14^{\circ}, 16^{\circ}, 18^{\circ}, 20^{\circ}, 22^{\circ}, 24^{\circ}, 26^{\circ}$ e $28^{\circ}$ dias de tratamento pelos animais pertencentes ao grupo So4\% em relação aos ratos do grupo controle. 
Os ganhos de peso médios semanais e totais destes ratos são apresentados na tabela 18 e ilustrados na figura 17. A análise de variância realizada revelou haver diferença significante entre os grupos na $1^{\circ}$ e $2^{\circ}$ semanas de tratamento $\left(F_{1}=21,47\right.$; $F_{2}=24,45 ; d f=2 / 27$, respectivamente, $\left.p<0,05\right)$, bem como no período total $(F=13,17$ e $\mathrm{df}=2 / 27$ ) do experimento. A aplicação do teste de Dunnett mostrou diminuição significante $(p<0,05)$ no ganho de peso semanal dos animais tratados com So4\% na primeira e na segunda semana de avaliação. Na avaliação do ganho de peso total, os animais pertencentes ao grupo So4\% apresentaram redução deste parâmetro quando comparados aos animais do grupo controle.

Em relação às observações clínicas, os seguintes sinais e sintomas, foram observados: letargia, abatimento, prostração, pêlos arrepiados e fezes amolecidas, a partir da segunda semana de tratamento em todos os animais pertencentes ao grupo So4\%.

Os resultados dos efeitos da administração de ração contendo $4 \%$ de sementes de $S$. occidentalis sobre os parâmetros hematológicos de ratos são apresentados na tabela 19 e ilustrados na figura 18. O número médio de eritrócitos (RBC) e leucócitos (WBC); e os valores médios de hemoglobina $(\mathrm{Hb})$, hematócrito (HCT), volume corpuscular médio (VCM), hemoglobina corpuscular média (HCM) e concentração de hemoglobina corpuscular média $(\mathrm{CHCM})$ são apresentados. A análise estatística revelou haver diminuição significante nos seguintes parâmetros avaliados $\mathrm{HCT}, \mathrm{Hb}, \mathrm{VCM}, \mathrm{HCM}$ e $\mathrm{WBC}\left(\mathrm{F}_{\mathrm{HCT}}=3,257 ; \mathrm{F}_{\mathrm{Hb}}=3,309 ; \mathrm{F}_{\mathrm{VCM}}=16,48\right.$; $\left.F_{H C M}=5,571 ; F_{W B C}=6,271 ; d f=2 / 27 ; p<0,05\right)$. A aplicação do teste estatístico apontou redução significante $(p<0,05)$ do HCT, HGB, VCM e HCM nos ratos pertencentes ao So4\%, quando comparado aos animais do grupo controle. Este mesmo teste, apontou redução estatisticamente significante $(p<0,05)$ nos valores de WBC 
$(F=0,6695 ; \mathrm{df}=2 / 27)$ nos animais pertencentes ao grupo $\mathrm{PF}$, quando comparados aos ratos do grupo controle. Os valores médios hematológicos do leucograma são apresentados na tabela 20. A leitura das extensões sangüíneas apontou hemácias microcíticas e hipocrômicas, bem como, diminuição do número de neutrófilos circulantes $(F=9,488 ; \quad d f=2 / 27, \quad p<0,05$ respectivamente $)$ em todos os ratos pertencentes ao grupo So4\%, em relação aos animais do grupo controle.

Os resultados obtidos na avaliação do peso relativo do baço e timo dos animais tratados com $4 \%$ de sementes de S. occidentalis na ração são apresentados na tabela 21. A análise estatística revelou haver diferença significante $(p<0,05)$ no peso relativo do baço $(F=4,098 ; d f=2 / 27)$, dos animais tratados, em relação aos animais pertencentes ao grupo controle (Figura 19).

A tabela 22 mostra a celularidade do baço e medula óssea dos ratos tratados com So4\% na ração e seus respectivos grupos controle. A análise estatística demonstrou haver diferença significante na celularidade da medula óssea $(F=0,0737 ; d f=2 / 27 ; p<0,05)$, como ilustrado na figura 20 . A aplicação do teste de Dunnett mostrou diminuição significante $(p<0,05)$ deste parâmetro nos animais pertencentes ao grupo So4\%, quando comparados aos animais do grupo controle.

Em relação ao estudo histopatológico de fragmentos histológicos provenientes do baço, timo, linfonodos, fígado e de diferentes porções do intestino, nenhuma alteração morfológica digna de nota foi observada em qualquer das amostras colhidas, de animais pertencentes aos diferentes grupos experimentais.

Em relação ao estudo histopatológico de fragmentos histológicos provenientes do timo, linfonodos, fígado e de diferentes porções do intestino, nenhuma alteração morfológica digna de nota foi observada em qualquer das amostras colhidas, de animais pertencentes aos diferentes grupos experimentais. 
Por outro lado, a análise morfológica do baço dos animais tratados com $4 \%$ de sementes de $S$. occidentalis na ração apresentou: desorganização do parênquima esplênico, proliferação hematopoiética extramedular caracterizada pela incidência de progenitores eritróides em diferentes estágios de maturação, e megacariócitos multinucleados (Figura 21) 

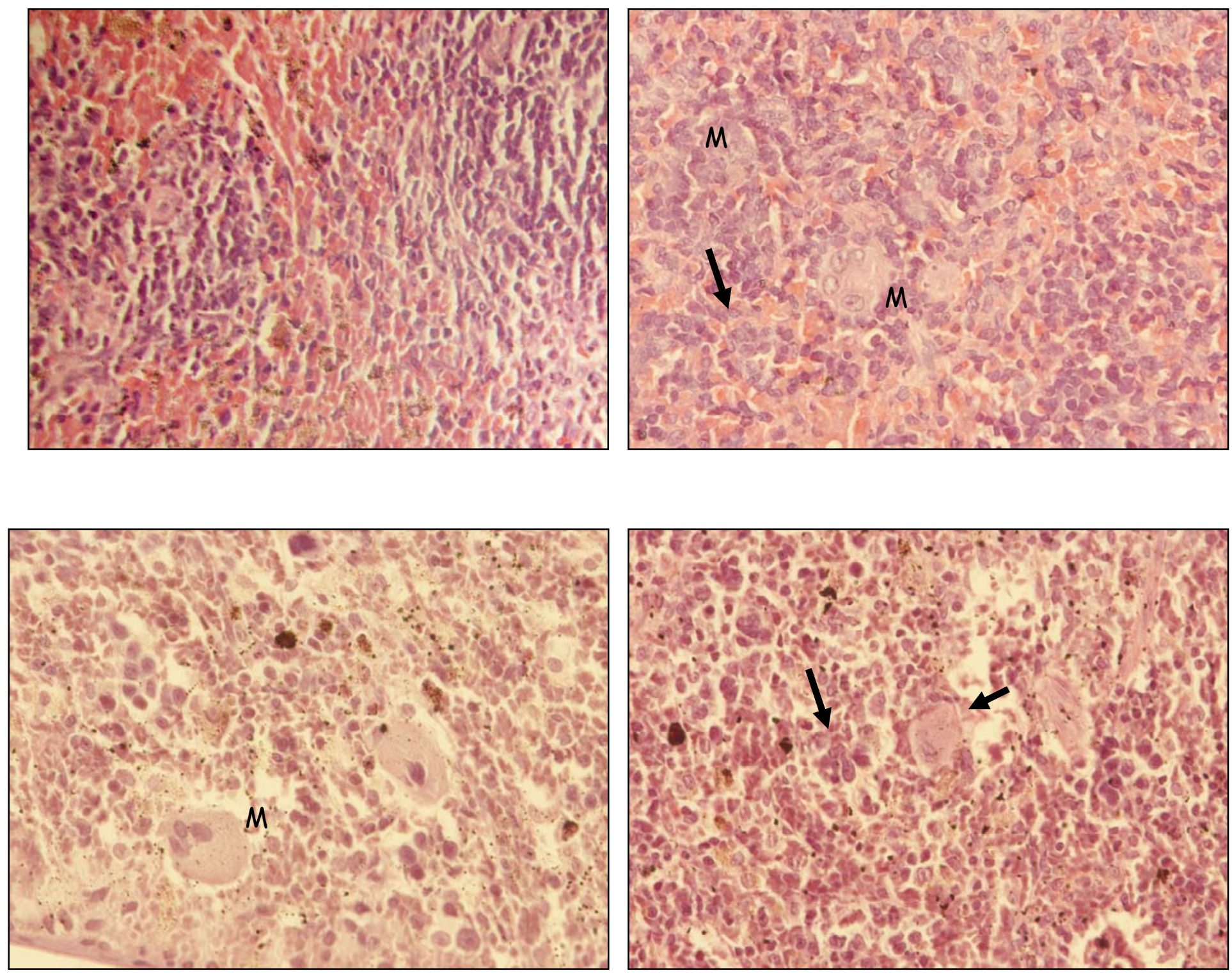

Figura 21 - Fotomicrográfia do baço de ratos recém-desmamados tratados durante 14 dias com sementes de $S$. occidentalis na ração. A. Integridade do parênquima esplênico com linfonodos bem delimitados, animal controle. B. Aumento do tamanho dos folículos linfóides e presença de megacariócitos (M), nos ratos do grupo So4\% (seta). C. Megacariócitos (M) visíveis com núcleo multilobulado e nucléolos proeminentes (seta), nos ratos do grupo So4\%. D. Progenitores eritróides em diferentes estágios de maturação (seta) nos ratos do grupo So4\%. (H.E. 40x) 
Tabela 16 - Consumo médio e total de ração (em g) pelos ratos recém-desmamados tratados durante 28 dias com 0 e $4 \%$ de sementes de $S$. occidentalis, na ração. Foram utilizados 10 animais por grupo. São apresentados as médias e os respectivos erros padrões

\begin{tabular}{|c|c|c|}
\hline \multirow{2}{*}{ Dias de tratamento } & \multicolumn{2}{|c|}{ Senna occidentalis (\%) } \\
\hline & 0 & 4 \\
\hline $4^{\circ}$ & $34,1 \pm 7,9$ & $31,5 \pm 5,8$ \\
\hline $6^{\circ}$ & $56,8 \pm 15,6$ & $52,7 \pm 12,9$ \\
\hline $8^{\circ}$ & $23,5 \pm 18,2$ & $24,5 \pm 14,3$ \\
\hline $12^{\circ}$ & $41,0 \pm 10,5$ & $33,4 \pm 12,4$ \\
\hline $14^{\circ}$ & $39,1 \pm 10,2$ & $24,8 \pm 7,0^{\mathrm{a}}$ \\
\hline $16^{\circ}$ & $40,6 \pm 11,2$ & $26,5 \pm 10,8^{a}$ \\
\hline $18^{\circ}$ & $43,1 \pm 10,7$ & $26,3 \pm 9,6^{a}$ \\
\hline $24^{\circ}$ & $41,9 \pm 11,6$ & $30,6 \pm 6,1$ \\
\hline $26^{\circ}$ & $36,6 \pm 15,4$ & $30,0 \pm 6,4$ \\
\hline $28^{\circ}$ & $38,8 \pm 9,9$ & $25,1 \pm 5,7^{a}$ \\
\hline Total & $36,3 \pm 4,1$ & $29,1 \pm 2,5^{\mathrm{a}}$ \\
\hline
\end{tabular}

${ }^{a}$ difere significantemente $(p<0,05)$ em relação ao controle $(0 \%)$ - (ANOVA, seguida de Dunnett). 


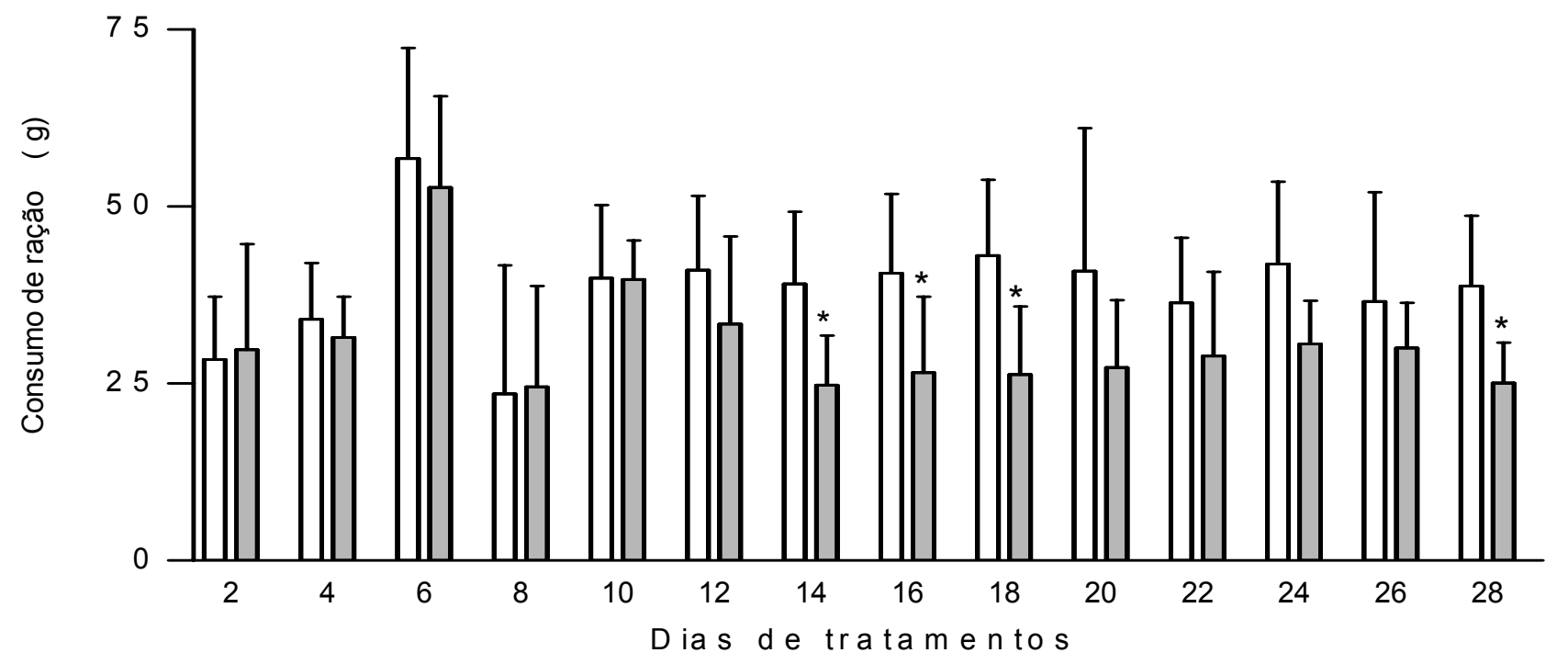

ए $0 \%$

* difere significantemente $(p<0,05)$ em relação ao controle $(0 \%)$ - (ANOVA, seguida de Dunnett)

Figura 15 - Consumo médio de ração (em g) pelos ratos recém-desmamados tratados durante 28 dias com 0 e $4 \%$ de sementes de $S$. occidentalis, na ração. Foram utilizados 10 animais por grupo. São apresentados as médias e os respectivos erros padrões 
Tabela 17 - Peso médio (em g), de ratos recém-desmamados tratados durante 28 dias com 0 e $4 \%$ de sementes de S. occidentalis, na ração e seu grupo peer-feeding (PF). Foram utilizados 10 animais por grupo. São apresentados as médias e os respectivos desvios padrões

\begin{tabular}{|c|c|c|c|}
\hline \multirow{2}{*}{ Dias de tratamento } & \multicolumn{2}{|c|}{ Senna occidentalis (\%) } & \multirow[b]{2}{*}{ PF } \\
\hline & 0 & 4 & \\
\hline $2^{\circ}$ & $123,9 \pm 15,6$ & $124,2 \pm 11,4$ & $126,2 \pm 14,1$ \\
\hline $4^{\circ}$ & $136,2 \pm 17,4$ & $132,3 \pm 12,2$ & $134,9 \pm 15,8$ \\
\hline $6^{\circ}$ & $151,1 \pm 13,2$ & $141,2 \pm 12,2$ & $149,0 \pm 15,6$ \\
\hline $8^{\circ}$ & $173,2 \pm 16,2$ & $157,8 \pm 11,6$ & $171,6 \pm 14,4$ \\
\hline $10^{\circ}$ & $177,6 \pm 15,5$ & $162,9 \pm 12,2^{a b}$ & $175,8 \pm 13,9$ \\
\hline $12^{\circ}$ & $192,0 \pm 17,5$ & $169,8 \pm 11,9^{a b}$ & $184,2 \pm 14,3$ \\
\hline $14^{\circ}$ & $206,3 \pm 20,1$ & $175,6 \pm 11,2^{\mathrm{ab}}$ & $201,1 \pm 18,4$ \\
\hline $16^{\circ}$ & $219,9 \pm 18,6$ & $183,0 \pm 21,5^{a b}$ & $217,7 \pm 19,0$ \\
\hline $18^{\circ}$ & $232,8 \pm 20,3$ & $189,6 \pm 12,1^{\mathrm{ab}}$ & $226,0 \pm 17,2$ \\
\hline $20^{\circ}$ & $247,9 \pm 18,0$ & $199,6 \pm 16,6^{a b}$ & $237,6 \pm 12,6$ \\
\hline $22^{\circ}$ & $262,9 \pm 18,6$ & $214,7 \pm 12,5^{\mathrm{ab}}$ & $250,4 \pm 13,4$ \\
\hline $24^{\circ}$ & $274,1 \pm 20,9$ & $224,4 \pm 11,3^{a b}$ & $263,4 \pm 11,4$ \\
\hline $26^{\circ}$ & $284,1 \pm 22,3$ & $233,1 \pm 11,9^{\mathrm{ab}}$ & $275,1 \pm 13,5$ \\
\hline $28^{\circ}$ & $297,2 \pm 21,7$ & $242,9 \pm 12,7^{\mathrm{ab}}$ & $283,9 \pm 18,6$ \\
\hline
\end{tabular}

\footnotetext{
a difere significantemente $(p<0,05)$ em relação ao controle $(0 \%)$ - (ANOVA,seguida de Dunnett).
}

${ }^{b}$ difere significantemente $(p<0,05)$ em relação ao PF (Teste " $t$ " Student). 


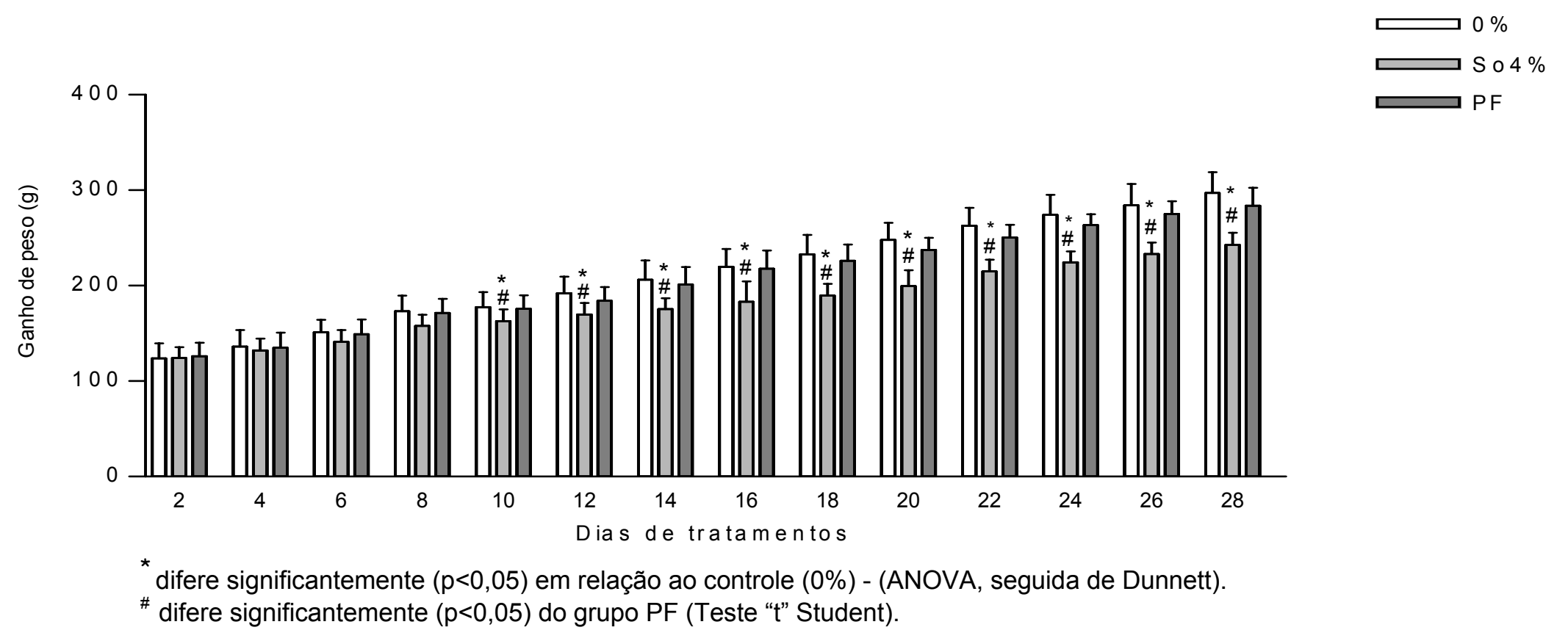

Figura 16 - Peso médio (em g), de ratos recém-desmamados tratados durante 28 dias com 0 e $4 \%$ de sementes de S. occidentalis, na ração e seu grupo peer-feeding (PF). Foram utilizados 10 animais por grupo. São apresentados as médias e os respectivos desvios padrões 
Tabela 18 - Peso semanal e total (em g), de ratos recém-desmamados tratados durante 28 dias com 0 e $4 \%$ de sementes de S. occidentalis, na ração e seu grupo peer-feeding (PF). Foram utilizados 10 animais por grupo. São apresentados as médias e os respectivos desvios padrões

\begin{tabular}{cccc}
\hline Semanas de tratamento & \multicolumn{2}{c}{ Senna occidentalis (\%) } & \multicolumn{1}{c}{ PF } \\
\cline { 2 - 4 } S1 & $\mathbf{0}$ & $\mathbf{4}$ & $12,2 \pm 5,7$ \\
S2 & $12,8 \pm 4,7$ & $8,0 \pm 3,4^{\text {ab }}$ & $11,5 \pm 1,7$ \\
Total & $12,7 \pm 1,7$ & $10,0 \pm 2,5^{\text {ab }}$ & $12,7 \pm 1,1$ \\
\hline
\end{tabular}

\footnotetext{
${ }^{a}$ difere significantemente $(p<0,05)$ em relação ao controle $(0 \%)$ - (ANOVA, seguida de Dunnett)
}

${ }^{b}$ difere significantemente $(p<0,05)$ em relação ao PF (Teste " $t$ " Student). 


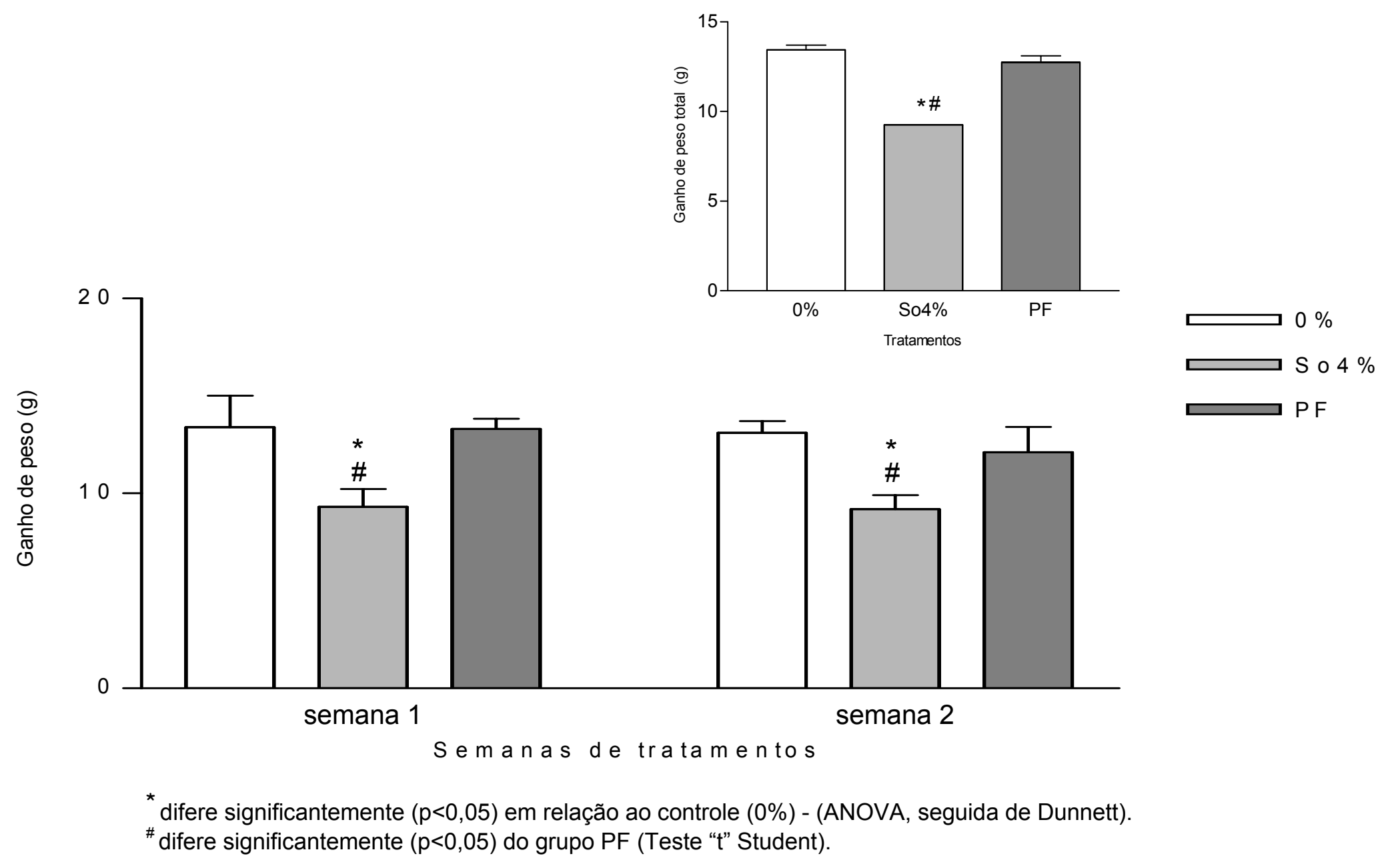

Figura 17 - Peso semanal e total (em g), de ratos recém-desmamados tratados durante 28 dias com 0 e $4 \%$ de sementes de sementes de $S$. occidentalis, na ração e seu grupo peer-feeding (PF). Foram utilizados 10 animais por grupo. São apresentados as médias e os respectivos desvios padrões 
Tabela 19 - Número médio de eritrócitos $\left(x 10^{6} / \mathrm{mm}^{3}\right)$ e leucócitos $\left(\times 10^{6} / \mathrm{mm}^{3}\right)$ e os valores médios do hematócrito - HCT (\%) e hemoglobina - Hb $(\mathrm{g} / \mathrm{dL})$, volume corpuscular médio - VCM $\left(\mu^{3}\right)$, hemoglobina corpuscular média - HCM ( $\left.\mu \mu \mathrm{g}\right)$ e concentração de hemoglobina corpuscular média - CHCM (\%), de ratos recém-desmamados tratados durante 28 dias com 0 e 4\% de sementes de $S$. occidentalis, na ração e seu grupo peer-feeding (PF). Foram utilizados 10 animais por grupo. São apresentados as médias e os respectivos desvios padrões

\begin{tabular}{|c|c|c|c|c|c|c|c|}
\hline \multirow[b]{2}{*}{ Grupos } & \multicolumn{7}{|c|}{ Parâmetros Hematológicos } \\
\hline & $\begin{array}{l}\text { Eritrócitos } \\
\left(\times 10^{6} / \mathrm{mm}^{3}\right)\end{array}$ & $\begin{array}{l}\text { Leucócitos } \\
\left(\times 10^{6} / \mathrm{mm}^{3}\right)\end{array}$ & $\begin{array}{l}\text { HCT } \\
(\%)\end{array}$ & $\begin{array}{c}\mathrm{Hb} \\
(\mathrm{g} / \mathrm{dL})\end{array}$ & $\begin{array}{l}\text { VCM } \\
\left(\mu^{3}\right)\end{array}$ & $\begin{array}{l}\text { HCM } \\
(\mu \mu \mathrm{g})\end{array}$ & $\begin{array}{c}\mathrm{CHCM} \\
(\%)\end{array}$ \\
\hline Controle & $6,1 \pm 0,32$ & $7,9 \pm 2,2$ & $39,8 \pm 1,8$ & $13,6 \pm 0,57$ & $65,0 \pm 0,94$ & $22,2 \pm 0,57$ & $34,1 \pm 0,64$ \\
\hline So4\% & $5,7 \pm 0,78$ & $7,3 \pm 2,7$ & $36,0 \pm 5,2^{\mathrm{a}}$ & $12,3 \pm 1,7^{a b}$ & $62,8 \pm 1,1^{a b}$ & $21,6 \pm 0,25^{a}$ & $34,3 \pm 0,67$ \\
\hline PF & $5,9 \pm 0,24$ & $10,9 \pm 1,9^{a}$ & $38,4 \pm 1,3$ & $13,0 \pm 0,36$ & $64,8 \pm 0,64$ & $22,1 \pm 0,33$ & $34,0 \pm 0,34$ \\
\hline
\end{tabular}

a difere significantemente $(p<0,05)$ em relação ao controle $(0 \%)$ - (ANOVA, seguida de Dunnett).

${ }^{b}$ difere significantemente $(p<0,05)$ em relação ao PF (Teste " $t$ " Student). 

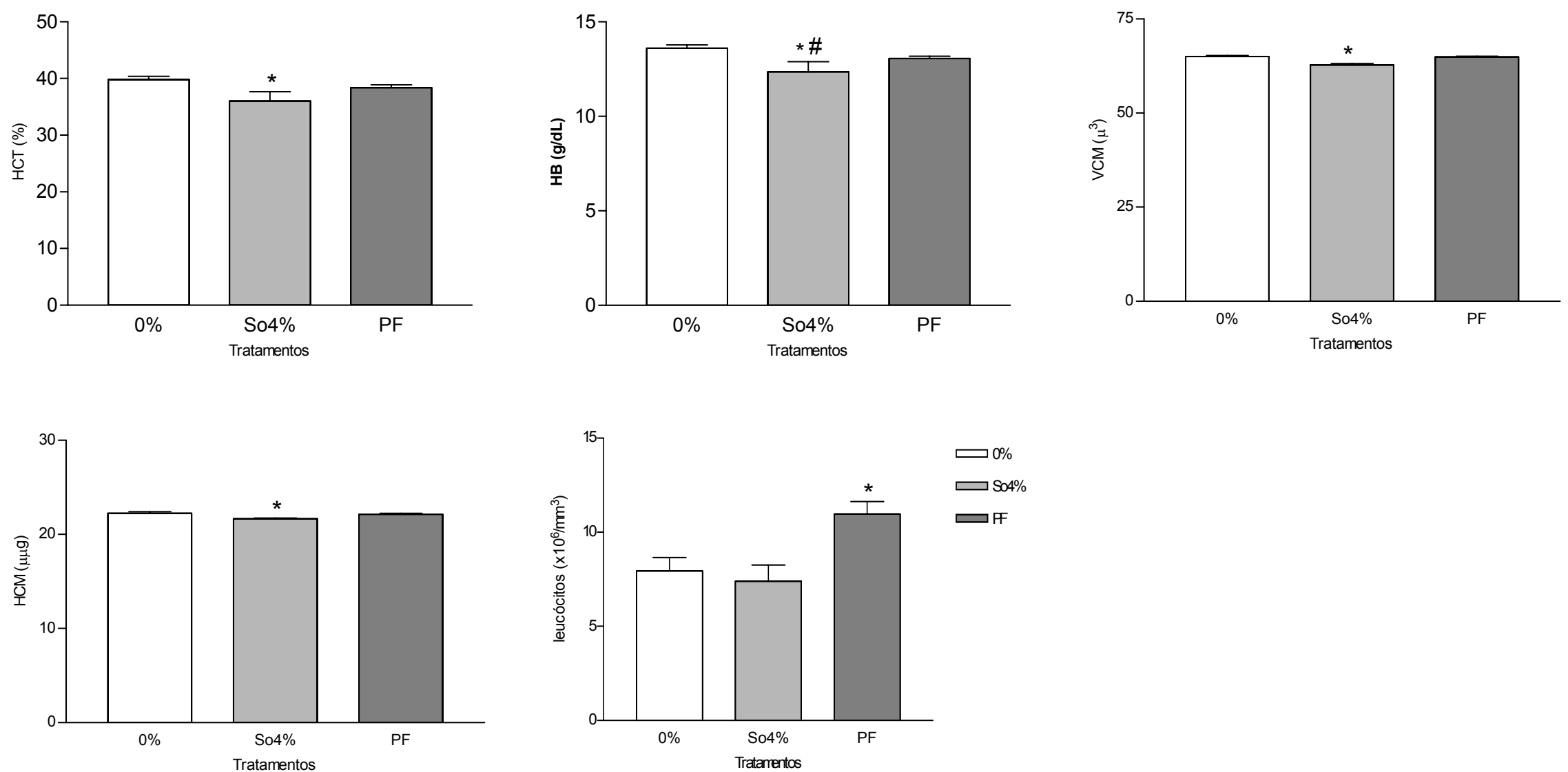

* difere significantemente $(p<0,05)$ em relação ao controle $(0 \%)$ - (ANOVA, seguida de Dunnett).

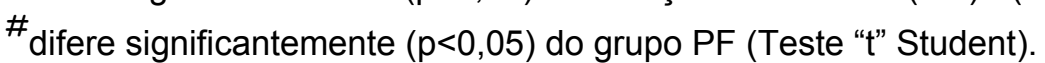

Figura 18 - Valor médio do hematócrito - HCT (\%), concentração de hemoglobina - HGB ( $\mathrm{g} / \mathrm{dL}$ ), do volume corpuscular médio VCM $\left(\mu^{3}\right)$, hemoglobina corpuscular média - HCM $(\mu \mu \mathrm{g})$ e de leucócitos $\left(\times 10^{6} / \mathrm{mm}^{3}\right)$ de ratos recém-desmamados tratados durante 28 dias com 0 e $4 \%$ de sementes de $S$. occidentalis, na ração e seu grupo peer-feeding (PF). Foram utilizados 10 animais por grupo. São apresentados as médias e os respectivos desvios padrões 
Tabela 20 - Média do número de linfócitos (em \%), neutrófilos segmentados (em\%), eosinófilos (em \%), bastonete (em \%) e monócitos (em \%), de ratos recém-desmamados tratados durante 28 dias com 0 e $4 \%$ de sementes de $S$. occidentalis, na ração e seu grupo peer-feeding (PF). Foram utilizados 10 animais por grupo. São apresentados as médias e os respectivos desvios padrões

\begin{tabular}{cccccc}
\hline & \multicolumn{3}{c}{ Parâmetros Hematológicos } \\
Lrupos & Linfócitos (\%) & Neutrófilos (\%) & Eosinófilos (\%) & Bastonetes (\%) & Monócitos (\%) \\
\cline { 2 - 6 } & $70,4 \pm 26,9$ & $24,4 \pm 6,3$ & $1,1 \pm 0,3$ & $2,3 \pm 0,8$ & $1,8 \pm 1,0$ \\
Controle & $79,1 \pm 7,7$ & $15,4, \pm 7,3^{\text {ab }}$ & $1,2 \pm 0,4$ & $2,3 \pm 0,5$ & $2,0 \pm 0,5$ \\
So4\% & $71,0 \pm 25,8$ & $23,4 \pm 4,9$ & $1,0 \pm 0,3$ & $2,4 \pm 0,5$ & $2,2 \pm 0,4$ \\
PF & & & & & \\
\hline
\end{tabular}

a difere significantemente $(p<0,05)$ em relação ao controle $(0 \%)$ - (ANOVA, seguida de Dunnett).

${ }^{\mathrm{b}}$ difere significantemente $(\mathrm{p}<0,05)$ em relação ao PF (Teste " $\mathrm{t}$ " Student). 
Tabela 21 - Peso relativo do baço e timo (g/ 100g pv), de ratos recém-desmamados tratados durante 28 dias com 0 e $4 \%$ de sementes de S. occidentalis, na ração e seu grupo peer-feeding (PF). Foram utilizados 10 animais por grupo. São apresentados as médias e os respectivos desvios padrões

\begin{tabular}{cccc}
\hline Órgão & \multicolumn{3}{c}{ Senna occidentalis (\%) } \\
\cline { 2 - 4 } & $\mathbf{0}$ & $\mathbf{4}$ & PF \\
baço & $0,302 \pm 0,048$ & $0,358 \pm 0,046^{\text {a }}$ & $0,313 \pm 0,045$ \\
timo & $0,206 \pm 0,032$ & $0,189 \pm 0,036$ & $0,199 \pm 0,041$
\end{tabular}

\footnotetext{
${ }^{a}$ difere significantemente $(p<0,05)$ em relação ao controle $(0 \%)$ - (ANOVA, seguida de Dunnett)
} 


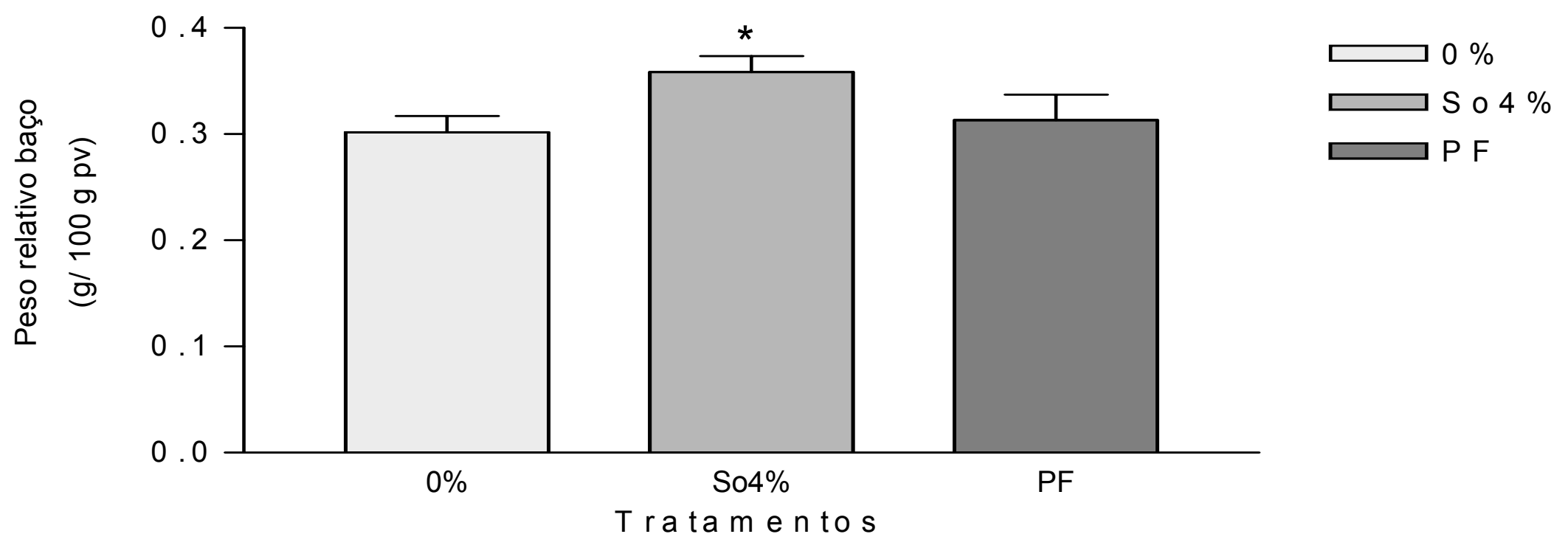

* difere significantemente $(p<0,05)$ em relação ao controle $(0 \%)$ - (ANOVA, seguida de Dunnett).

Figura 19 - Peso relativo do baço $(\mathrm{g} / 100 \mathrm{~g} \mathrm{pv})$, de ratos recém-desmamados tratados durante 28 dias com 0 e $4 \%$ de sementes de S. occidentalis, na ração e seu grupo peer-feeding (PF). Foram utilizados 10 animais por grupo. São apresentados as médias e os respectivos desvios padrões 
Tabela 22 - Celularidade do baço e da medula óssea (x 10\% /cel), de ratos recém-desmamados tratados durante 28 dias com 0 e $4 \%$ de sementes de S. occidentalis, na ração e seu grupo peer-feeding (PF). Foram utilizados 10 animais por grupo. São apresentados as médias e os respectivos desvios padrões

\begin{tabular}{ccc}
\hline Órgão & \multicolumn{2}{c}{ Senna occidentalis (\%) } \\
\cline { 2 - 3 } & $\mathbf{0}$ & $\mathbf{4}$ \\
\hline baço & $0,991 \pm 0,35$ & $0,903 \pm 0,32$ \\
medula óssea & $0,251 \pm 0,04$ & $0,206 \pm 0,03^{\mathrm{ab}}$
\end{tabular}

${ }^{a}$ difere significantemente $(p<0,05)$ em relação ao controle $(0 \%)$ - (ANOVA, seguida de Dunnett).

${ }^{b}$ difere significantemente $(p<0,05)$ em relação ao PF (Teste "t" Student). 


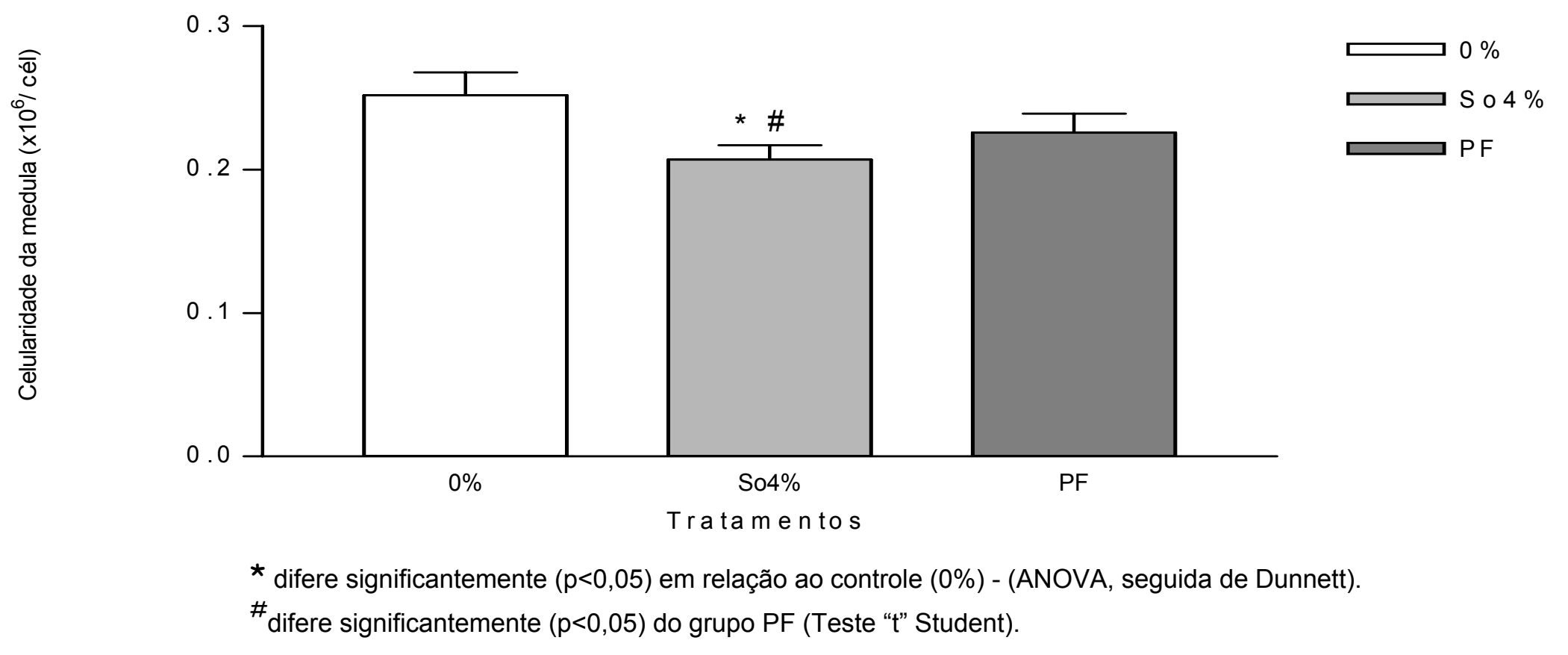

Figura 20 - Celularidade da medula óssea (x 10\% $/ \mathrm{cel}$ ), de ratos recém-desmamados tratados durante 28 dias com 0 e $4 \%$ de sementes de $S$. occidentalis, na ração e seu grupo peer-feeding (PF). Foram utilizados 10 animais por grupo. São apresentados as médias e os respectivos desvios padrões 


\subsection{EXPERIMENTO 5: AVALIAÇÃO DO BURST OXIDATIVO E DA FAGOCITOSE} DE NEUTRÓFILOS POR CITOMETRIA DE FLUXO, DE RATOS RECÉMDESMAMADOS, TRATADOS COM 0 E $4 \%$ DE SEMENTES DE S. occidentalis NA RAÇÃO DURANTE 28 DIAS E SEU GRUPO PEERFEEDING.

A tabela 23 mostra o consumo médio e total de ração pelos ratos durante o experimento. Assim, a análise estatística realizada revelou não haver diferença significante $(p>0,05)$ entre os grupos, sendo que o consumo de ração dos animais do grupo $\mathrm{PF}$ foi idêntico àquele dos ratos submetidos à administração de ração contendo $4 \%$ de sementes de S. occidentalis (dados não apresentados).

Em relação ao peso médio destes animais (Tabela 24 e Figura 22), as análises de variância realizadas revelaram haver diferença significante entre os grupos no $10^{\circ}, 12^{\circ}, 14^{\circ}, 16^{\circ}, 18^{\circ}, 20^{\circ}, 22^{\circ}, 24^{\circ}, 26^{\circ}$ e $28^{\circ}$ dias do experimento $\left(F_{10}=\right.$ 5,$911 ; F_{12}=9,490 ; F_{14}=19,99 ; F_{16}=36,40 ; F_{18}=34,61 ; F_{20}=31,41 ; F_{22}=28,01 ; F_{24}=$ 23,$91 ; \quad F_{26}=26,05 ; \quad F_{28}=41,61 ; \quad d f=2 / 27$, respectivamente, $\left.\quad p<0,05\right)$, quando comparado aos resultados obtidos dos animais pertencentes ao grupo controle. A aplicação do teste de Dunnett mostrou redução significante $(p<0,05)$ deste parâmetro no $10^{\circ}, 12^{\circ}, 14^{\circ}, 16^{\circ}, 18^{\circ}, 20^{\circ}, 22^{\circ}, 24^{\circ}, 26^{\circ}$ e $28^{\circ}$ dias de tratamento pelos animais pertencentes ao grupo So $4 \%$ em relação aos ratos do grupo controle. Este mesmo teste apontou diminuição significante $(p<0,05)$ no ganho de peso, pelos animais pertencentes ao grupo PF no $24^{\circ}, 26^{\circ}$ e $28^{\circ}$ dias de tratamento, quando comparados aos ratos do grupo controle. 
Os ganhos de peso médios semanais e totais destes ratos são apresentados na tabela 25 e ilustrados na figura 23. A análise de variância realizada revelou haver diferença significante entre os grupos na $1^{\circ}$ semana de tratamento $\left(F_{1}=7,487\right.$; $d f=2 / 27$, respectivamente, $p<0,05)$. A aplicação do teste de Dunnett mostrou diminuição significante $(p<0,05)$ no ganho de peso semanal dos animais tratados com So4\% na primeira semana de avaliação. Este mesmo teste mostrou não haver diferença significante $(p>0,05)$ entre os grupos de animais tratados, quando comparados aos seus respectivos controle, quanto ao ganho de peso total.

Em relação às observações clínicas, os seguintes sinais e sintomas, foram observados: letargia, abatimento, prostração, pêlos arrepiados e fezes amolecidas, a partir na segunda semana de tratamento em todos os animais pertencentes ao grupo So4\%.

A tabela 26 mostra avaliação do burst oxidativo e da fagocitose de neutrófilos, por citometria de fluxo, de ratos recém-desmamados, tratados com diferentes concentrações de $S$. occidentalis na ração. A análise de variância realizada revelou haver diferença significante $(p<0,05)$ entre os grupos, na fluorescência do burst basal $(F=4,144$; $d f=2 / 27)$, no burst induzido por SAPI $(F=$ $5,133 ; 2 / 27)$, no burst induzido por PMA $(F=4,973 ; \mathrm{df}=2 / 27)$ e na intensidade $(F=$ $26,00 ; d f=2 / 27)$, bem como, na porcentagem de fagocitose $(F=6,294 ; d f=2 / 27) d e$ neutrófilos. A aplicação do teste de Dunnett mostrou haver redução significante $(p<0,05)$, na fluorescência do burst basal, no burst induzido por SAPI, no burst induzido por PMA; e na intensidade e na porcentagem de fagocitose, nos animais pertencentes ao grupo So4, em relação aos animais do grupo controle. Este mesmo teste apontou ainda, diminuição significante $(p<0,05)$, na florescência do burst oxidativo induzido por SAPI, na intensidade de fluorescência da fagocitose, bem 
como, na porcentagem de neutrófilos que fagocitaram partículas de SAPI, naqueles animais pertencentes ao grupo PF, quando comparados aos ratos do grupo controle (figura 24). 
Tabela 23 - Consumo médio e total de ração (em g) pelos ratos recém-desmamados tratados durante 28 dias com 0 e $4 \%$ de sementes de $S$. occidentalis, na ração. Foram utilizados 10 animais por grupo. São apresentados as médias e os respectivos desvios padrões

\begin{tabular}{|c|c|c|}
\hline Dias de tratamento & 0 & 4 \\
\hline $2^{\circ}$ & $15,1 \pm 4,7$ & $18,5 \pm 3,6$ \\
\hline $4^{\circ}$ & $22,1 \pm 5,1$ & $28,8 \pm 6,9$ \\
\hline $6^{\circ}$ & $34,1 \pm 12,3$ & $35,2 \pm 6,9$ \\
\hline $8^{\circ}$ & $29,4 \pm 4,5$ & $32,3 \pm 8,9$ \\
\hline $10^{\circ}$ & $29,8 \pm 8,9$ & $34,6 \pm 7,1$ \\
\hline $12^{\circ}$ & $34,8 \pm 5,1$ & $33,5 \pm 8,8$ \\
\hline $14^{\circ}$ & $41,3 \pm 8,2$ & $54,4 \pm 17,3$ \\
\hline $16^{\circ}$ & $43,4 \pm 16,3$ & $53,4 \pm 16,0$ \\
\hline $18^{\circ}$ & $41,6 \pm 10,3$ & $40,2 \pm 19,7$ \\
\hline $20^{\circ}$ & $35,9 \pm 7,8$ & $34,2 \pm 10,5$ \\
\hline $22^{\circ}$ & $29,7 \pm 6,0$ & $33,9 \pm 5,6$ \\
\hline $24^{\circ}$ & $33,4 \pm 7,5$ & $31,6 \pm 3,7$ \\
\hline $26^{\circ}$ & $38,4 \pm 7,2$ & $32,2 \pm 5,5$ \\
\hline $28^{\circ}$ & $32,4 \pm 5,9$ & $32,5 \pm 6,2$ \\
\hline Total & $32,9 \pm 7,6$ & $35,3 \pm 9,1$ \\
\hline
\end{tabular}


Tabela 24 - Peso médio (em g), de ratos recém-desmamados tratados durante 28 dias com 0 e $4 \%$ de sementes de S. occidentalis, na ração e seu grupo peer-feeding (PF). Foram utilizados 10 animais por grupo. São apresentados as médias e os respectivos desvios padrões

\begin{tabular}{|c|c|c|c|}
\hline \multirow{2}{*}{ Dias de tratamento } & \multicolumn{2}{|c|}{ Senna occidentalis (\%) } & \multirow[b]{2}{*}{ PF } \\
\hline & 0 & 4 & \\
\hline $2^{\circ}$ & $61,8 \pm 4,8$ & $63,1 \pm 7,6$ & $63,6 \pm 11,6$ \\
\hline $4^{\circ}$ & $71,3 \pm 4,5$ & $68,7 \pm 6,0$ & $69,1 \pm 6,6$ \\
\hline $6^{\circ}$ & $82,8 \pm 5,7$ & $79,0 \pm 7,5$ & $81,7 \pm 7,7$ \\
\hline $8^{\circ}$ & $96,6 \pm 6,3$ & $8,8 \pm 7,9$ & $96,2 \pm 8,0$ \\
\hline $10^{\circ}$ & $108,9 \pm 7,2$ & $95,3 \pm 9,6^{a b}$ & $105,0 \pm 9,5$ \\
\hline $12^{\circ}$ & $120,3 \pm 7,9$ & $102,5 \pm 10,8^{\mathrm{ab}}$ & $114,3 \pm 9,0$ \\
\hline $14^{\circ}$ & $143,3 \pm 18,4$ & $106,3 \pm 10,7^{\mathrm{ab}}$ & $129,9 \pm 8,3$ \\
\hline $16^{\circ}$ & $149,0 \pm 9,2$ & $114,1 \pm 11,1^{\mathrm{ab}}$ & $145,4 \pm 9,7$ \\
\hline $18^{\circ}$ & $165,3 \pm 13,0$ & $122,3 \pm 10,3^{a b}$ & $155,8 \pm 12,4$ \\
\hline $20^{\circ}$ & $182,5 \pm 18,3$ & $130,6 \pm 12,1^{\mathrm{ab}}$ & $162,9 \pm 13,1$ \\
\hline $22^{\circ}$ & $188,4 \pm 12,3$ & $143,3 \pm 13,4^{a b}$ & $175,0 \pm 14,7$ \\
\hline $24^{\circ}$ & $205,3 \pm 25,1$ & $152,7 \pm 13,4^{\mathrm{ab}}$ & $187,0 \pm 8,8^{a}$ \\
\hline $26^{\circ}$ & $233,9 \pm 23,8$ & $174,7 \pm 17,0^{\mathrm{ab}}$ & $208,2 \pm 12,5^{a}$ \\
\hline $28^{\circ}$ & $244,1 \pm 20,7$ & $178,3 \pm 15,9^{\mathrm{ab}}$ & $218,4 \pm 10,5^{a}$ \\
\hline
\end{tabular}

${ }^{a}$ difere significantemente $(p<0,05)$ em relação ao controle $(0 \%)$ - (ANOVA,seguida de Dunnett).

${ }^{b}$ difere significantemente $(p<0,05)$ em relação ao PF (Teste " $t$ " Student). 


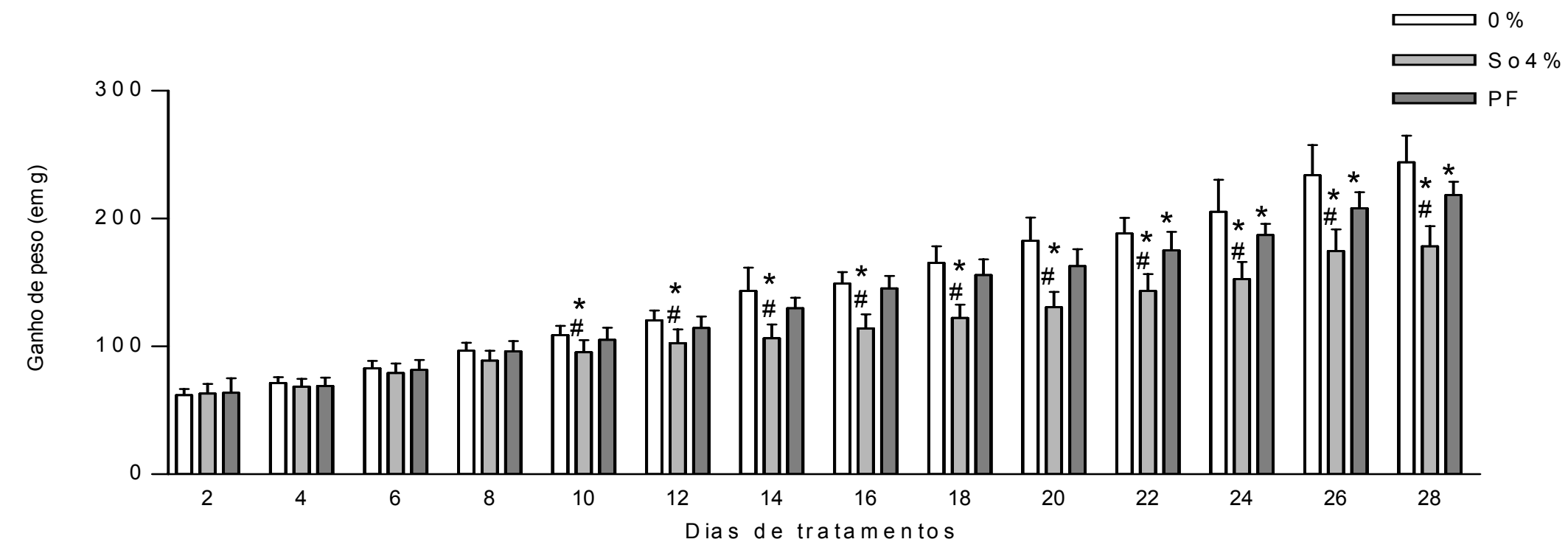

* difere significantemente $(p<0,05)$ em relação ao controle $(0 \%)$ - (ANOVA, seguida de Dunnett).

\# difere significantemente $(p<0,05)$ do grupo PF (Teste "t" Student).

Figura 22 - Peso médio (em g), de ratos recém-desmamados tratados durante 28 dias com 0 e $4 \%$ de sementes de S. occidentalis, na ração e seu grupo peer-feeding (PF). Foram utilizados 10 animais por grupo. São apresentados as médias e os respectivos desvios padrões 
Tabela 25 - Peso semanal e total (em g), de ratos recém-desmamados tratados durante 28 dias com 0 e $4 \%$ de sementes de S. occidentalis, na ração e seu grupo peer-feeding (PF). Foram utilizados 10 animais por grupo. São apresentados as médias e os respectivos desvios padrões

\begin{tabular}{|c|c|c|c|}
\hline \multirow{2}{*}{ Semanas de tratamento } & \multicolumn{3}{|c|}{ Senna occidentalis (\%) } \\
\hline & 0 & 4 & PF \\
\hline s1 & $10,9 \pm 2,1$ & $6,9 \pm 2,0^{a b}$ & $10,9 \pm 3,6$ \\
\hline S2 & $13,6 \pm 4,4$ & $11,3 \pm 4,6$ & $12,2 \pm 3,9$ \\
\hline Total & $12,3 \pm 3,6$ & $9,1 \pm 4,1$ & $11,6 \pm 3,7$ \\
\hline
\end{tabular}

a difere significantemente $(p<0,05)$ em relação ao controle $(0 \%)$ - (ANOVA, seguida de Dunnett).

${ }^{b}$ difere significantemente $(p<0,05)$ em relação ao PF (Teste "t" Student). 


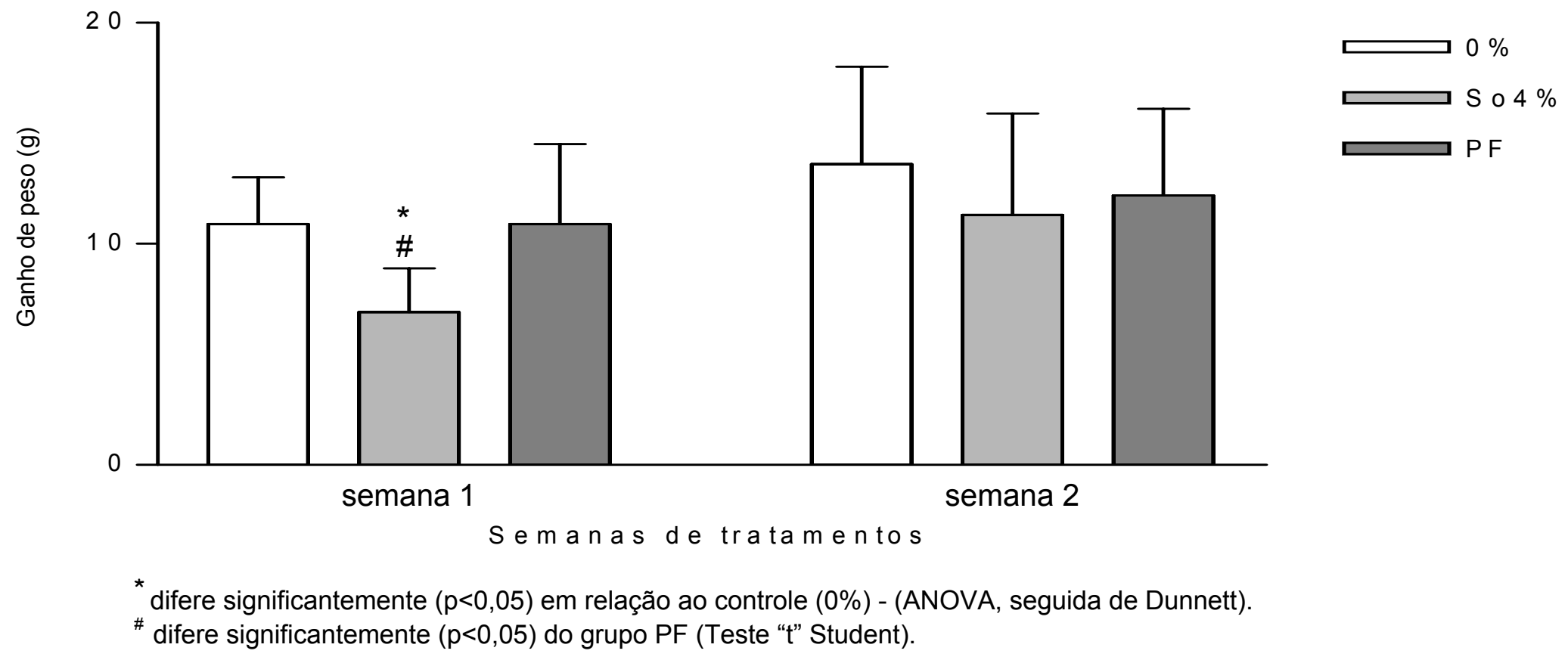

Figura 23 - Peso semanal e total (em g), de ratos recém-desmamados tratados durante 28 dias com 0 e $4 \%$ de sementes de sementes de $S$. occidentalis, na ração e seu grupo peer-feeding (PF). Foram utilizados 10 animais por grupo. São apresentados as médias e os respectivos desvios padrões 
Tabela 26 - Avaliação do burst oxidativo e da fagocitose de neutrófilos, de ratos recém-desmamados tratados durante 28 dias com 0 e $4 \%$ de sementes de sementes de $S$. occidentalis, na ração e seu grupo peer-feeding (PF). Foram utilizados 10 animais por grupo. São apresentados as médias e os respectivos desvios padrões

\begin{tabular}{|c|c|c|c|}
\hline \multirow[b]{2}{*}{ Parâmetros } & \multicolumn{3}{|c|}{ Senna occidentalis (\%) } \\
\hline & 0 & 4 & PF \\
\hline Burst basal & $69,7 \pm 18,5$ & $51,3 \pm 6,1^{a}$ & $67,1 \pm 18,3$ \\
\hline Burst SAPI & $275,1 \pm 73,4$ & $197,2 \pm 76,9^{a}$ & $186,5 \pm 31,6^{a}$ \\
\hline Burst PMA & $394,7 \pm 51,2$ & $274,8 \pm 104,3^{a b}$ & $327,1 \pm 62,2$ \\
\hline Burst DCFH & $87,4 \pm 8,2$ & $82,1 \pm 10,5$ & $85,8 \pm 7,6$ \\
\hline$\%$ Fagocitose ${ }^{c 1}$ & $81,4 \pm 7,5$ & $68,5 \pm 9,3^{a}$ & $69,1 \pm 9,1^{a}$ \\
\hline Intensidade fagocitose ${ }^{\mathrm{c} 2}$ & $60,7 \pm 3,3$ & $42,3 \pm 6,7^{a}$ & $39,8 \pm 6,9^{a}$ \\
\hline
\end{tabular}

Os dados representam a intensidade média de fluorescência (médias e os respectivos desvios padrões), correspondentes ao gate da população de neutrófilos sangüíneos.

${ }^{a}$ difere significantemente $(p<0,05)$ em relação ao controle $(0 \%)$ - (ANOVA,seguida de Dunnett).

${ }^{b}$ difere significantemente $(p<0,05)$ em relação ao PF (Teste " $t$ " Student).

${ }^{c 1}$ porcentagem de neutrófilos que fagocitaram partículas de SAPI.

quantidade de bactérias, que foram fagocitadas pela população de neutrófilos. Expressas pela média geométrica da intensidade de fluorescência da população de neutrófilos. 

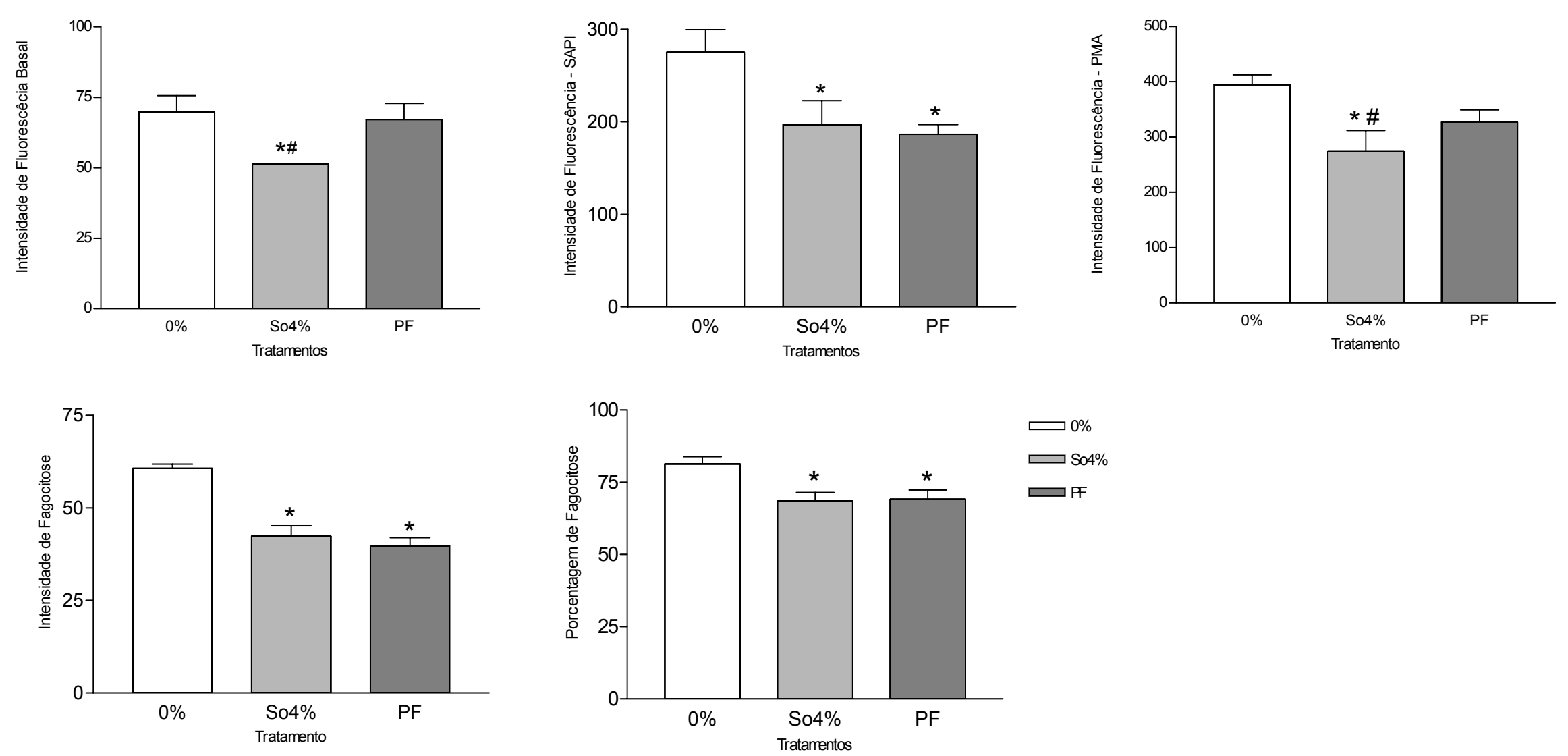

* difere significantemente $(p<0,05)$ em relação ao controle $(0 \%)$ - (ANOVA, seguida de Dunnett).

\# difere significantemente $(p<0,05)$ do grupo PF (Teste "t" Student).

Figura 24 - Avaliação do burst oxidativo e da fagocitose de neutrófilos, de ratos recém-desmamados tratados durante 28 dias com 0 e $4 \%$ de sementes de sementes de $S$. occidentalis, na ração e seu grupo peer-feeding (PF). Foram utilizados 10 animais por grupo. São apresentados as médias e os respectivos desvios padrões 


\subsection{EXPERIMENTO 6: EFEITOS DA ADMINISTRAÇÃO DAS DIFERENTES} CONCENTRAÇÕES DE SEMENTES DE S. occidentalis NA RAÇÃO DE RATAS TRATADAS DO $6^{\circ}$ AO $20^{\circ}$ DIA DE GESTAÇÃO

A tabela 27 mostra e a figura 25 ilustra, o consumo médio e total de ração pelas ratas tratadas a partir do $6^{\circ}$ dias ate $020^{\circ}$ dia de gestação com diferentes concentrações de $S$. occidentalis na ração. Assim, a análise estatística realizada revelou haver diferença significante $(F=9,923$; $d f=3 / 36$; respectivamente $p<0,05)$ entre os grupos no período total do experimento sendo que o consumo dos animais do grupo peer-feeding (PF) foi idêntico àquele das ratas submetidos à administração de ração contendo $4 \%$ de sementes de S. occidentalis (dados não apresentados). $\mathrm{Na}$ avaliação do consumo total de ração, o teste de Dunnett revelou haver diminuição significante $(p<0,05)$ neste parâmetro nas ratas gestantes pertencentes aos grupos experimentais So2 e So4, quando comparadas aquelas do grupo controle.

Em relação ao peso médio destes animais (Tabela 28), a análise de variância realizada revelou não haver diferença significante $(p>0,05)$ entre as ratas gestantes dos grupos experimentais quando comparadas aquelas pertencentes ao grupo controle.

O ganho de peso médio semanal e total destas ratas é apresentado na tabela 29. Assim, a análise de variância realizada revelou não haver diferença significante $(p>0,05)$ entre os grupos tratados em relação aos animais do grupo controle. 
Em relação às observações clínicas, os seguintes sinais e sintomas, foram observados: pêlos arrepiados e fezes amolecidas, a partir do $18^{\circ}$ dias de gestação em todas as ratas gestantes pertencentes ao grupo So4.

A tabela 30 mostra o desempenho reprodutivo de ratas gestantes que receberam diferentes concentrações de sementes de $S$. occidentalis do $6^{\circ}$ ao $20^{\circ}$ dia de gestação e de seus respectivos grupos controle que receberam apenas ração comercial durante o mesmo período. A análise de variância revelou não haver diferenças significantes $(p>0,05)$ entre os diversos grupos experimentais comparados ao grupo controle.

Os resultados dos efeitos da administração de ração contendo diferentes concentrações de sementes de $S$. occidentalis sobre o número médio de eritrócitos (RBC) e leucócitos (WBC) destes animais são apresentados na tabela 31. A análise estatística revelou não haver diminuição significante $(p>0,05)$, neste parâmetro entre os valores obtidos dos animais pertencentes aos grupos experimentais em relação aqueles obtidos dos animais do grupo controle. De maneira semelhante, na contagem diferencial de leucócitos (Tabela 32) nenhuma alteração significante $(p>0,05)$ foi observada entre os animais tratados quando comparados aos controles.

Os resultados obtidos na avaliação do peso relativo do baço de ratas tratadas com as diferentes concentrações de $S$. occidentalis na ração são apresentados na tabela 33 e ilustrados na figura 26. A análise estatística revelou haver diferença significante $(p<0,05)$ no peso relativo do baço $\left(F_{\text {baço }}=1,936 ; \quad d f=4 / 35\right.$, respectivamente, $p<0,05)$. A aplicação do teste de Dunnett apontou aumento significante $(p<0,05)$ no peso relativo deste órgão nas ratas pertencentes ao grupo So4\%, quando comparadas aos animais do grupo controle. 
A tabela 34 mostra a celularidade do baço e medula óssea de ratas tratadas com as diferentes concentrações de $S$. occidentalis na ração durante a gestação. A análise estatística apontou não haver diferença significante $(p>0,05)$ na celularidade da medula óssea de ratas tratadas com a planta durante a gestação, quando comparadas aquelas pertencentes ao grupo controle. Em relação à celularidade do baço, ilustrada na figura 27, a aplicação do teste de Dunnett apontou diminuição significante $(F=3,342 ; d f=4 / 35$, respectivamente, $p<0,05)$ deste parâmetro em todos os animais dos grupos tratados, em relação aos animais pertencentes ao grupo controle.

Em relação ao estudo histopatológico de fragmentos histológicos provenientes do baço, timo, linfonodos, fígado e de diferentes porções do intestino, nenhuma alteração morfológica digna de nota foi observada em qualquer das amostras colhidas, de animais pertencentes aos diferentes grupos experimentais. 
Tabela 27 - Consumo médio e total de ração $(\mathrm{g})$ pelas ratas tratadas do $6^{\circ}$ ao $20^{\circ}$ dias de gestação com diferentes concentrações $(0 \%, 1 \%, 2 \%$ e $4 \%)$ de sementes de $S$. occidentalis, na ração. Foram utilizados 8 animais por grupo. São apresentados as médias e os respectivos desvios padrões

\begin{tabular}{|c|c|c|c|c|}
\hline \multirow{2}{*}{ Dias de tratamento } & \multicolumn{4}{|c|}{ Senna occidentalis (\%) } \\
\hline & 0 & 1 & 2 & 4 \\
\hline $6^{\circ}$ & $148,7 \pm 25,5$ & $157,9 \pm 29,5$ & $175,9 \pm 27,0$ & $141,8 \pm 34,7$ \\
\hline $9^{\circ}$ & $157,9 \pm 29,5$ & $175,9 \pm 27,0$ & $141,8 \pm 34,7$ & $127,4 \pm 28,7$ \\
\hline $12^{\circ}$ & $173,4 \pm 37,6$ & $158,6 \pm 12,4$ & $159,1 \pm 26,6$ & $150,8 \pm 26,7$ \\
\hline $18^{\circ}$ & $164,9 \pm 8,5$ & $157,8 \pm 29,6$ & $154,1 \pm 39,4$ & $148,1 \pm 20,1$ \\
\hline $15^{\circ}$ & $133,3 \pm 10,2$ & $141,4 \pm 30,7$ & $130,5 \pm 29,9$ & $135,9 \pm 25,5$ \\
\hline $20^{\circ}$ & $172,9 \pm 24,0$ & $163,4 \pm 27,7$ & $155,8 \pm 22,4$ & $160,5 \pm 22,8$ \\
\hline Total & $167,3 \pm 7,3$ & $163,9 \pm 8,3$ & $152,7 \pm 7,5^{a}$ & $146,7 \pm 13,9^{a}$ \\
\hline
\end{tabular}

a difere significantemente $(p<0,05)$ em relação ao controle $(0 \%)$ - (ANOVA, seguida de Dunnett). 


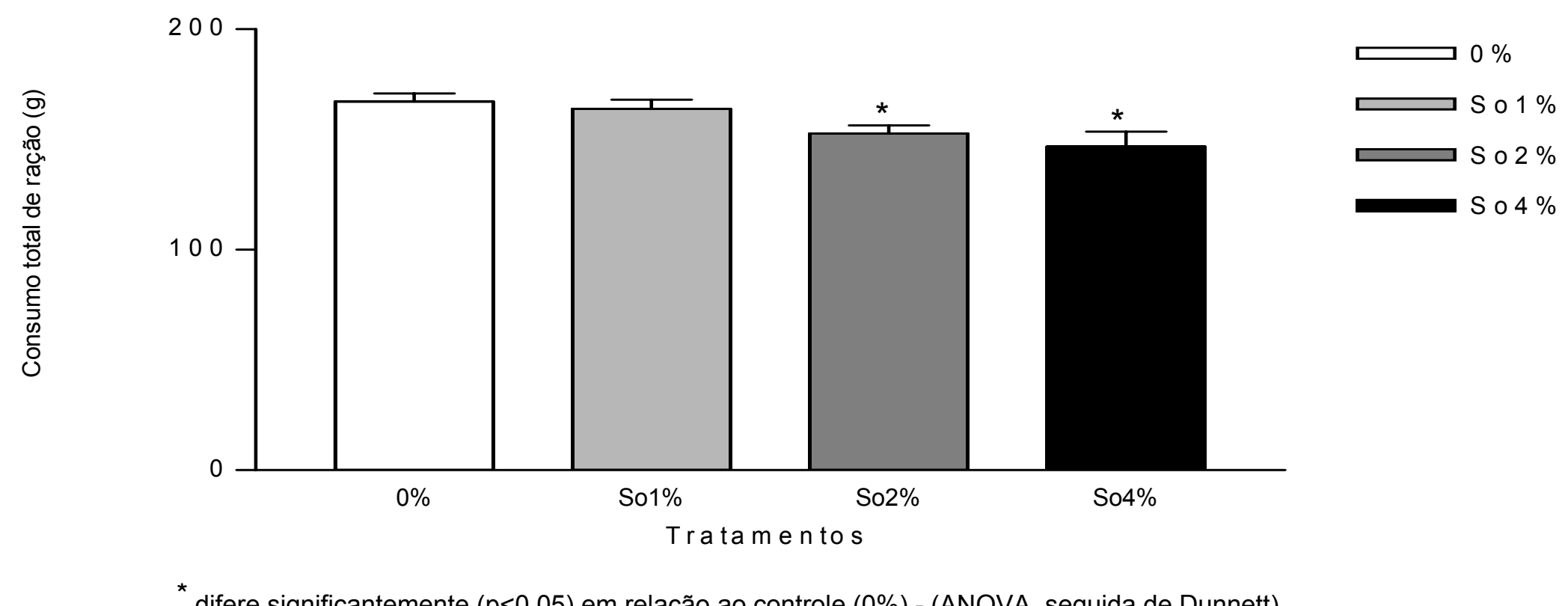

* difere significantemente $(p<0,05)$ em relação ao controle $(0 \%)$ - (ANOVA, seguida de Dunnett).

Figura 25 - Consumo médio e total de ração $(\mathrm{g})$ pelas ratas tratadas do $6^{\circ}$ ao $20^{\circ}$ dias de gestação com diferentes concentrações $(0 \%, 1 \%, 2 \%$ e $4 \%)$ de sementes de S. occidentalis, na ração. Foram utilizados 8 animais por grupo. São apresentados as médias e os respectivos desvios padrões 
Tabela 28 - Peso médio $(\mathrm{g})$, de ratas tratadas do $6^{\circ}$ ao $20^{\circ}$ dias de gestação com diferentes concentrações $(0 \%, 1 \%, 2 \%$ e $4 \%$ ) de sementes de S. occidentalis, na ração e seu grupo peer-feeding (PF). Foram utilizados 8 animais por grupo. São apresentados as médias e os respectivos desvios padrões

\begin{tabular}{cccccc}
\hline $\begin{array}{c}\text { Dias de } \\
\text { tratamento }\end{array}$ & \multicolumn{3}{c}{ Senna occidentalis (\%) } \\
\cline { 2 - 6 } & $\mathbf{0}$ & $\mathbf{1}$ & $\mathbf{2}$ & $\mathbf{4}$ & PF \\
\hline $\mathbf{6}^{\mathbf{0}}$ & $244,9 \pm 39,7$ & $231,6 \pm 33,8$ & $235,9 \pm 31,5$ & $226,1 \pm 16,8$ & $238,0 \pm 20,8$ \\
$\mathbf{9}^{\circ}$ & $264,9 \pm 37,6$ & $242,8 \pm 35,8$ & $251,9 \pm 30,2$ & $236,1 \pm 17,7$ & $251,0 \pm 14,9$ \\
$\mathbf{1 2}^{\mathbf{0}}$ & $268,8 \pm 36,6$ & $261,4 \pm 39,9$ & $265,1 \pm 28,0$ & $243,4 \pm 15,2$ & $273,4 \pm 21,8$ \\
$\mathbf{1 5}^{\mathbf{0}}$ & $283,4 \pm 42,4$ & $272,8 \pm 35,8$ & $274,5 \pm 28,9$ & $253,6 \pm 20,0$ & $289,6 \pm 23,4$ \\
$\mathbf{1 8}^{\mathbf{0}}$ & $295,4 \pm 38,2$ & $293,4 \pm 39,1$ & $298,3 \pm 32,0$ & $260,3 \pm 23,6$ & $321,3 \pm 33,7$ \\
$\mathbf{2 0}^{\mathbf{0}}$ & $311,0 \pm 30,4$ & $308,3 \pm 35,5$ & $316,0 \pm 26,9$ & $285,1 \pm 15,3$ & $342,9 \pm 39,2$ \\
\hline
\end{tabular}


Tabela 29 - Peso semanal e total $(\mathrm{g})$, de ratas tratadas do $6^{\circ}$ ao $20^{\circ}$ dias de gestação com diferentes concentrações $(0 \%, 1 \%, 2 \%$ e $4 \%)$ de sementes de $S$. occidentalis, na ração e seu grupo peer-feeding (PF). Foram utilizados 8 animais por grupo. São apresentados as médias e os respectivos desvios padrões

\begin{tabular}{cccccc}
\hline $\begin{array}{c}\text { Semanas de } \\
\text { tratamento }\end{array}$ & \multicolumn{5}{c}{ Senna occidentalis (\%) } \\
\cline { 2 - 6 } & $\mathbf{0}$ & $\mathbf{1}$ & $\mathbf{2}$ & $\mathbf{4}$ & $\mathbf{P F}$ \\
\hline S1 & $11,9 \pm 2,8$ & $13,1 \pm 2,2$ & $12,5 \pm 1,5$ & $9,5 \pm 2,4$ & $12,1 \pm 2,1$ \\
S2 & $11,4 \pm 3,5$ & $13,8 \pm 2,1$ & $14,5 \pm 1,4$ & $10,8 \pm 3,1$ & $11,5 \pm 2,3$ \\
Total & $11,6 \pm 2,9$ & $13,5 \pm 2,0$ & $13,5 \pm 1,7$ & $10,2 \pm 2,7$ & $11,8 \pm 2,0$ \\
\hline
\end{tabular}


Tabela 30 - Desempenho reprodutivo de ratas tratadas do $6^{\circ}$ ao $20^{\circ}$ dias de gestação com diferentes concentrações $(0 \%$, $1 \%, 2 \%$ e $4 \%$ ) de sementes de S. occidentalis, na ração e seu grupo peer-feeding (PF). Foram utilizados 8 animais por grupo. São apresentados as médias e os respectivos desvios padrões

\begin{tabular}{|c|c|c|c|c|c|}
\hline Parâmetros & 0 & 1 & 2 & 4 & PF \\
\hline $\begin{array}{l}\text { Peso médio materno }(\mathrm{g}) \text { no } 20^{\circ} \text { dia de } \\
\text { gestação }\end{array}$ & $255,6 \pm 36,6$ & $230,7 \pm 32,6$ & $235,8 \pm 26,2$ & $243,3 \pm 19,2$ & $273,5 \pm 16,5$ \\
\hline Peso médio do útero gravídico $(\mathrm{g})$ & $22,5 \pm 3,2$ & $18,8 \pm 4,8$ & $22,0 \pm 3,5$ & $21,5 \pm 4,3$ & $22,5 \pm 6,3$ \\
\hline Peso médio materno sem o útero $(\mathrm{g})$ & $264,2 \pm 21,4$ & $243,7 \pm 40,1$ & $250,6 \pm 28,8$ & $224,6 \pm 12,7^{*}$ & $254,6 \pm 29,8$ \\
\hline Peso médio da placenta $(\mathrm{g})$ & $2,24 \pm 0,31$ & $2,23 \pm 0,15$ & $2,29 \pm 0,18$ & $2,27 \pm 0,14$ & $2,24 \pm 0,17$ \\
\hline Peso médio fetal & $3,92 \pm 0,74$ & $3,36 \pm 0,76$ & $4,02 \pm 1,02$ & $3,86 \pm 1,27$ & $4,3 \pm 1,06$ \\
\hline Peso médio da ninhada (g) & $50,9 \pm 6,78$ & $40,0 \pm 4,96$ & $45,9 \pm 4,68$ & $42,7 \pm 4,82$ & $35,8 \pm 5,89$ \\
\hline $\mathrm{N}^{0}$ de fetos vivos & $11,0 \pm 2,9$ & $10,0 \pm 1,5$ & $11,0 \pm 1,8$ & $10,0 \pm 1,6$ & $12,0 \pm 3,1$ \\
\hline$N^{0}$ fetos mortos & $1,0 \pm 0,75$ & $0,50 \pm 0,75$ & $0,62 \pm 0,74$ & $0,62 \pm 0,51$ & $0,25 \pm 0,46$ \\
\hline$N^{0}$ fetos machos & $5,6 \pm 2,7$ & $4,33 \pm 1,0$ & $4,75 \pm 1,6$ & $5,14 \pm 1,3$ & $5,00 \pm 1,7$ \\
\hline$N^{0}$ fetos fêmeas & $6,6 \pm 1,9$ & $6,16 \pm 1,6$ & $6,75 \pm 1,7$ & $5,42 \pm 1,51$ & $6,00 \pm 2,8$ \\
\hline Comprimento dos fetos $(\mathrm{cm})$ & $4,23 \pm 0,61$ & $4,42 \pm 0,64$ & $4,44 \pm 0,93$ & $3,90 \pm 0,73$ & $4,33 \pm 0,91$ \\
\hline$N^{0}$ de corpos lúteos & $12,1 \pm 2,4$ & $11,0 \pm 1,6$ & $1,7 \pm 1,0$ & $11,7 \pm 1,7$ & $11,3 \pm 3,7$ \\
\hline$N^{0}$ de implantações & $12,4 \pm 1,07$ & $11,8 \pm 0,37$ & $12,0 \pm 0,46$ & $11,1 \pm 0,40$ & $12,3 \pm 1,35$ \\
\hline $\mathrm{N}^{\circ}$ de reabsorções & $0 \pm 0,0$ & $0,4 \pm 0,0$ & $0,62 \pm 0,26$ & $1 \pm 0,5$ & $0,33 \pm 0,21$ \\
\hline \% perda pós-implantação & $8,5 \pm 6,2$ & $13,0 \pm 11,6$ & $6,5 \pm 9,3$ & $11,5 \pm 11,7$ & $3,5 \pm 6,6$ \\
\hline
\end{tabular}


Tabela 31 - Número médio de eritrócitos $\left(\times 10^{6} / \mathrm{mm}^{3}\right)$ e leucócitos $\left(\times 10^{6} / \mathrm{mm}^{3}\right)$ de ratas tratadas do $6^{\circ}$ ao $20^{\circ}$ dias de gestação com diferentes concentrações $(0 \%, 1 \%, 2 \%$ e $4 \%)$ de sementes de S. occidentalis, na ração e seu grupo peerfeeding (PF). Foram utilizados 8 animais por grupo. São apresentados as médias e os respectivos desvios padrões

\begin{tabular}{|c|c|c|c|c|c|}
\hline \multirow{2}{*}{ Parâmetros Hematológicos } & \multicolumn{5}{|c|}{ Grupos } \\
\hline & 0 & 1 & 2 & 4 & $\mathrm{PF}$ \\
\hline Eritrócitos $\left(\times 10^{6} / \mathrm{mm}^{3}\right)$ & $5,9 \pm 0,56$ & $6,5 \pm 1,6$ & $6,3 \pm 1,5$ & $6,3 \pm 0,48$ & $5,4 \pm 1,9$ \\
\hline Leucócitos $\left(\times 10^{6} / \mathrm{mm}^{3}\right)$ & $6,3 \pm 2,2$ & $6,0 \pm 3,1$ & $8,3 \pm 2,3$ & $12,5 \pm 3,7$ & $10,7 \pm 3,4$ \\
\hline
\end{tabular}


Tabela 32 - Média do número de linfócitos (em \%), neutrófilos segmentados (em\%), eosinófilos (em \%), bastonete (em \%) e monócitos (em \%), de ratas tratadas do $6^{\circ}$ ao $20^{\circ}$ dias de gestação com diferentes concentrações $(0 \%, 1 \%, 2 \%$ e $4 \%$ ) de sementes de $S$. occidentalis, na ração e seu grupo peer-feeding (PF). Foram utilizados 8 animais por grupo. São apresentados as médias e os respectivos desvios padrões

\begin{tabular}{|c|c|c|c|c|c|}
\hline \multirow[b]{2}{*}{ Grupos } & \multicolumn{5}{|c|}{ Parâmetros Hematológicos } \\
\hline & Linfócitos (\%) & Neutrófilos (\%) & Eosinófilos (\%) & Bastonetes (\%) & Monócitos (\%) \\
\hline Controle & $68,0 \pm 0,9$ & $25,0 \pm 0,6$ & $1,0 \pm 0,1$ & $2,0 \pm 0,2$ & $4,0 \pm 0,5$ \\
\hline So1\% & $70,0 \pm 1,0$ & $24,0 \pm 0,6$ & $1,0 \pm 0,1$ & $2,0 \pm 0,4$ & $3,0 \pm 0,4$ \\
\hline So $2 \%$ & $73,0 \pm 1,0$ & $22,0 \pm 0,8$ & $1,0 \pm 0,1$ & $2,0 \pm 0,6$ & $3,0 \pm 0,4$ \\
\hline So4\% & $71,0 \pm 0,5$ & $22,0 \pm 0,5$ & $1,0 \pm 0,1$ & $3,0 \pm 0,7$ & $3,0 \pm 0,3$ \\
\hline PF & $69,0 \pm 1,0$ & $23,0 \pm 0,7$ & $1,0 \pm 0,1$ & $2,0 \pm 0,5$ & $4,0 \pm 1,0$ \\
\hline
\end{tabular}


Tabela 33 - Peso relativo do baço $(\mathrm{g} / 100 \mathrm{~g} \mathrm{pv})$, de ratas tratadas do $6^{\circ}$ ao $20^{\circ}$ dias de gestação com diferentes concentrações $(0 \%, 1 \%, 2 \%$ e $4 \%)$ de sementes de S. occidentalis, na ração e seu grupo peer-feeding (PF). Foram utilizados 8 animais por grupo. São apresentados as médias e os respectivos desvios padrões

\begin{tabular}{ccccc}
\hline \multirow{2}{*}{ órgãos } & $\mathbf{0}$ & \multicolumn{3}{c}{ Senna occidentalis (\%) } \\
\cline { 2 - 5 } & $0,208 \pm 0,033$ & $0,231 \pm 0,033$ & $\mathbf{2}$ & $\mathbf{4}$ \\
\hline baço & & $0,238 \pm 0,021$ & $0,255 \pm 0,035^{\mathrm{a}}$ \\
& & & \\
& & & & \\
\end{tabular}

${ }^{a}$ difere significantemente $(p<0,05)$ em relação ao controle $(0 \%)$ - (ANOVA, seguida de Dunnett). 


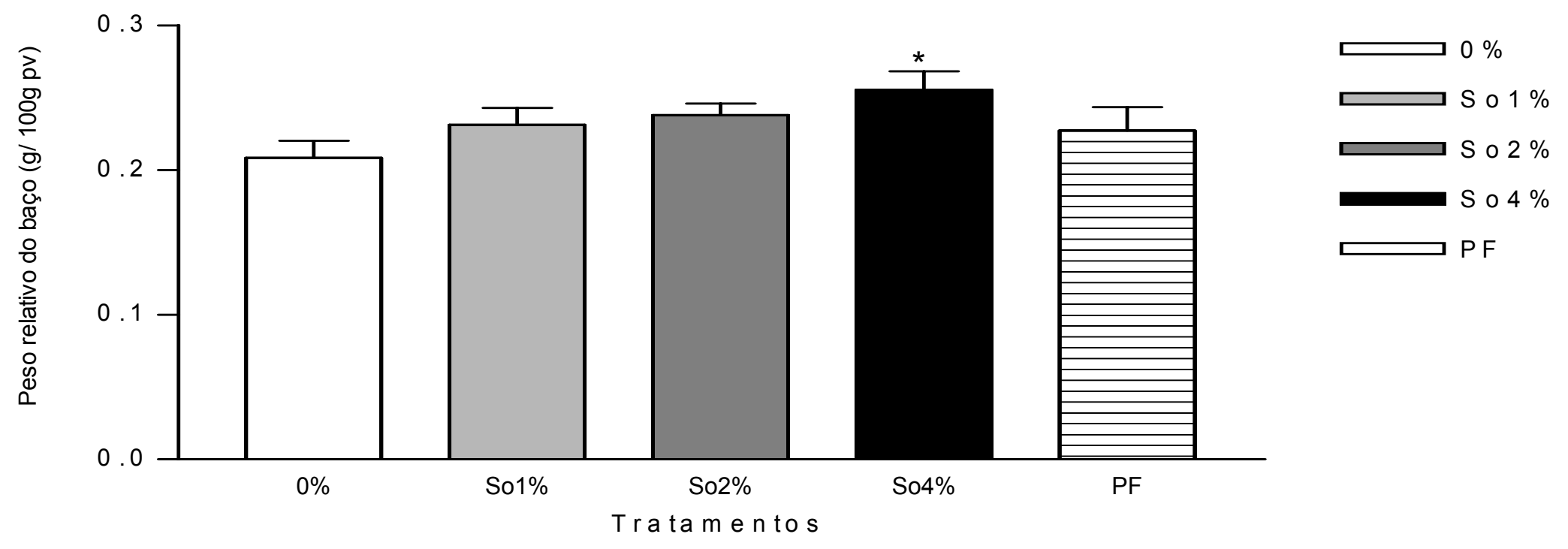

* difere significantemente $(p<0,05)$ em relação ao controle (ANOVA, seguida de Dunnett).

Figura 26 - Peso relativo do baço $(\mathrm{g} / 100 \mathrm{~g} \mathrm{pv})$, de ratas tratadas do $6^{\circ}$ ao $20^{\circ}$ dias de gestação com diferentes concentrações $(0 \%, 1 \%, 2 \%$ e $4 \%)$ de sementes de S. occidentalis, na ração e seu grupo peer-feeding. Foram utilizados 8 animais por grupo. São apresentados as médias e os respectivos desvios padrões 
Tabela 34 - Celularidade do baço e da medula óssea (x 10\% /cel), de ratas tratadas do $6^{\circ}$ ao $20^{\circ}$ dias de gestação com diferentes concentrações $(0 \%, 1 \%, 2 \%$ e $4 \%)$ de sementes de S. occidentalis, na ração e seu grupo peerfeeding (PF). Foram utilizados 8 animais por grupo. São apresentados as médias e os respectivos desvios padrões

\begin{tabular}{|c|c|c|c|c|c|}
\hline \multirow{2}{*}{ Órgão } & \multicolumn{5}{|c|}{ Senna occidentalis (\%) } \\
\hline & 0 & 1 & 2 & 4 & PF \\
\hline baço & $2,1 \pm 1,1$ & $0,75 \pm 0,38^{a}$ & $0,61 \pm 0,21^{a}$ & $0,77 \pm 0,48^{a b}$ & $1,9 \pm 1,0$ \\
\hline medula óssea & $0,98 \pm 0,28$ & $1,3 \pm 0,71$ & $1,3 \pm 0,30$ & $1,5 \pm 0,57$ & $1,3 \pm 0,39$ \\
\hline
\end{tabular}

${ }^{a}$ difere significantemente $(p<0,05)$ em relação ao controle $(0 \%)$ - (ANOVA, seguida de Dunnett).

${ }^{b}$ difere significantemente $(p<0,05)$ em relação ao PF (Teste "t" Student). 


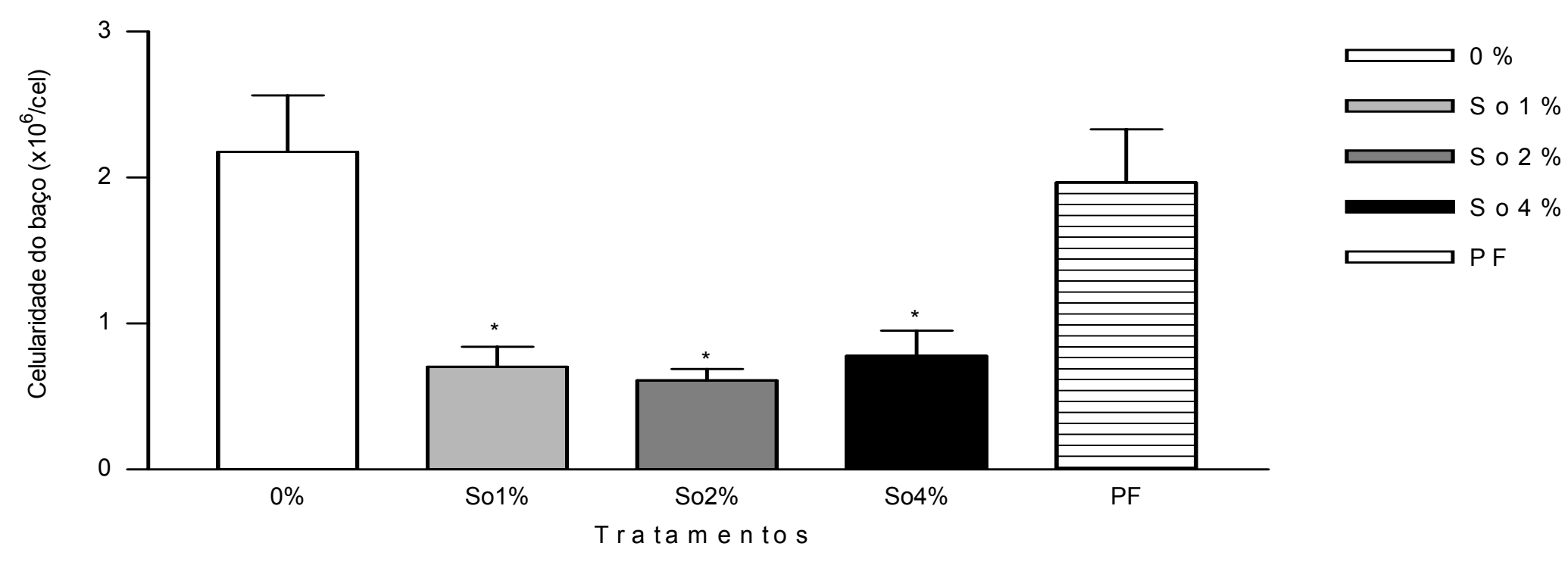

* difere significantemente $(p<0,05)$ em relação ao controle $(0 \%)$ - (ANOVA, seguida de Dunnett).

\# difere significantemente $(p<0,05)$ do grupo PF (Teste "t" Student).

Figura 27 - Celularidade do baço $\left(\times 10^{6} / \mathrm{cel}\right)$, de ratas tratadas do $6^{\circ}$ ao $20^{\circ}$ dias de gestação com diferentes concentrações $(0 \%, 1 \%, 2 \%$ e $4 \%)$ de sementes de S. occidentalis, na ração e seu grupo peer-feeding (PF). Foram utilizados 8 animais por grupo. São apresentados as médias e os respectivos desvios padrões 


\subsection{EXPERIMENTO 7: AVALIAÇÃO DO SISTEMA IMUNE E HEMATOPOÉTICO,} NA PROLE DE RATAS TRATADAS COM 0 E 4\% DE SEMENTES DE S. occidentalis NA RAÇÃO E SEU GRUPO PEER-FEEDING

A tabela 35 mostra, o consumo médio e total de ração pelas ratas tratadas a partir do $6^{\circ}$ dias ate $\circ 20^{\circ}$ dia de gestação com $4 \%$ de sementes de S. occidentalis na ração e seu grupo peer-feeding. Assim, a análise estatística realizada revelou não haver diferença significante entre os grupos durante os dias de tratamento, bem como, no período total do experimento, sendo que o consumo de ração dos animais do grupo $\mathrm{PF}$ foi idêntico àquele dos ratos submetidos à administração de ração contendo $4 \%$ de sementes de S. occidentalis (dados não apresentados).

Em relação ao peso médio destes animais (Tabela 36), a análise de variância realizada revelou não haver diferença significante $(p>0,05)$ entre as ratas gestantes do grupo So4, quando comparadas aquelas pertencentes ao grupo controle.

O ganho de peso médio semanal e total destas ratas é apresentado na tabela 37. Assim, a análise de variância realizada revelou não haver diferença significante $(p>0,05)$ entre os grupos tratados em relação aos animais do grupo controle.

Em relação às observações clínicas, os seguintes sinais e sintomas, foram observados: pêlos arrepiados e fezes amolecidas, a partir do $12^{\circ}$ dias de gestação em todas as ratas gestantes pertencentes ao grupo So $4 \%$.

No dia seguinte ao nascimento, procedeu-se então com a avaliação do número de filhotes nascidos e a razão sexual. dos filhotes de cada 'prole. como demonstrado na tabela 38. Assim, a análise de variância realizada revelou não haver diferença significante $(p>0,05)$ entre os grupos tratados em relação aos animais do 
grupo controle. Após o procedimento descrito acima, todas as proles foram homogeneizadas e escolhidos aleatoriamente, sempre que possível 4 filhotes de cada sexo, para cada mãe. Estes animais totalizaram 40 fêmeas e 40 machos. No $22^{\circ}$ dia de vida estes animais foram separados em dois subgrupos iguais, com 20 fêmeas e 20 machos, para a realização dos protocolos experimentais,como descrito nos resultados 4.7.1, 4.7.2 e 4.7.3, respectivamente. 
Tabela 35 - Consumo médio e total de ração (em g) pelas ratas tratadas do $6^{\circ}$ ao $20^{\circ}$ dias de gestação com 0 e $4 \%$ de sementes de $S$. occidentalis na ração. Foram utilizados 10 animais por grupo. São apresentados as médias e os respectivos desvios padrões

\begin{tabular}{|c|c|c|}
\hline \multirow{2}{*}{ Dias de tratamento } & \multicolumn{2}{|c|}{ Senna occidentalis (\%) } \\
\hline & 0 & 4 \\
\hline $6^{\circ}$ & $148,7 \pm 23,5$ & $147,9 \pm 28,5$ \\
\hline $9^{\circ}$ & $147,9 \pm 23,4$ & $145,9 \pm 23,0$ \\
\hline $12^{\circ}$ & $163,4 \pm 17,6$ & $158,6 \pm 11,4$ \\
\hline $18^{\circ}$ & $174,9 \pm 7,5$ & $177,8 \pm 9,6$ \\
\hline $15^{\circ}$ & $153,3 \pm 8,2$ & $151,4 \pm 7,7$ \\
\hline $20^{\circ}$ & $162,9 \pm 4,0$ & $165,4 \pm 7,7$ \\
\hline Total & $167,3 \pm 7,3$ & $163,9 \pm 8,3$ \\
\hline
\end{tabular}


Tabela 36 - Peso médio (em g), de ratas tratadas do $6^{\circ}$ ao $20^{\circ}$ dias de gestação com 0 e $4 \%$ de sementes de $S$. occidentalis na ração e seu grupo peer-feeding (PF). Foram utilizados 10 animais por grupo. São apresentados as médias e os respectivos desvios padrões

\begin{tabular}{cccc}
\hline \multirow{2}{*}{ Dias de tratamento } & \multicolumn{3}{c}{ Senna occidentalis (\%) } \\
\cline { 2 - 4 } $\mathbf{6}^{\circ}$ & 0 & $224,9 \pm 22,8$ & $\mathrm{PF}$ \\
$\mathbf{9}^{\circ}$ & $220,5 \pm 33,4$ & $247,3 \pm 24,0$ & $25,3 \pm 31,5$ \\
$\mathbf{1 2}^{\circ}$ & $247,1 \pm 23,6$ & $259,9 \pm 17,9$ & $245,3 \pm 28,0$ \\
$\mathbf{1 5}^{\circ}$ & $253,4 \pm 21,6$ & $267,5 \pm 25,8$ & $273,8 \pm 28,9$ \\
$\mathbf{1 8}^{\circ}$ & $274,4 \pm 20,4$ & $282,4 \pm 30,1$ & $285,3 \pm 31,0$ \\
$\mathbf{2 0}^{\circ}$ & $284,8 \pm 28,2$ & $290,6 \pm 22,5$ & $295,8 \pm 13,9$ \\
\hline
\end{tabular}


Tabela 37 - Peso semanal e total (em g), de ratas tratadas do $6^{\circ}$ ao $20^{\circ}$ dias de gestação com 0 e $4 \%$ de sementes de S. occidentalis na ração e seu grupo peer-feeding (PF). Foram utilizados 10 animais por grupo. São apresentados as médias e os respectivos desvios padrões

\begin{tabular}{|c|c|c|c|}
\hline \multirow{2}{*}{ Semanas de tratamento } & \multicolumn{3}{|c|}{ Senna occidentalis (\%) } \\
\hline & 0 & 4 & PF \\
\hline S1 & $10,2 \pm 4,7$ & $9,1 \pm 4,1$ & $10,5 \pm 2,9$ \\
\hline S2 & $11,9 \pm 9,3$ & $10,7 \pm 7,8$ & $12,5 \pm 4,6$ \\
\hline Total & $10,3 \pm 7,5$ & $8,4 \pm 3,8$ & $11,0 \pm 5.3$ \\
\hline
\end{tabular}


Tabela 38 - Parâmetros reprodutivos de ratas que consumiram 0 e $4 \%$ de sementes de $S$. occidentalis na ração do $6^{\circ}$ ao $20^{\circ}$ dia de gestação, e seu grupo peer-feeding (PF). Foram utilizados 10 animais por grupo. São apresentados as médias e os respectivos desvios padrões

\begin{tabular}{|c|c|c|c|}
\hline \multicolumn{4}{|c|}{ Senna occidentalis (\%) } \\
\hline Parâmetros & 0 & 4 & $\mathrm{PF}$ \\
\hline Número de ratas prenhes & $10 / 10$ & $10 / 10$ & $10 / 10$ \\
\hline Filhotes vivos & 11 & 12 & 11 \\
\hline Filhotes mortos & 0 & 0 & 0 \\
\hline Número de machos & $6(80,00)$ & $6(50,00)$ & $6(80,00)$ \\
\hline Número de fêmeas & $5(20,00)$ & $6(50,00)$ & $5(20,00)$ \\
\hline Mortalidade dos filhotes pós-parto & 0 & 0 & 0 \\
\hline
\end{tabular}




\subsubsection{Experimento 7.1: Avaliação na prole de ratas tratadas com 0 e $4 \%$ de sementes de S. occidentalis na ração e seu grupo peer-feeding}

Em relação ao peso médio destes animais (Tabela 39), as análises de variância realizadas revelaram não haver diferença significante entre os grupos, bem como entre machos e fêmeas, quando comparado aos resultados obtidos dos animais pertencentes ao grupo controle.

Os ganhos de peso médios semanais e totais destes ratos são apresentados na tabela 40. A análise de variância realizada revelou não haver diferença significante entre os grupos na $1^{\circ}$ e $2^{\circ}$ semanas de vida, bem como, no período ganho de peso total. Além disso, não foi observada nenhuma alteração clinica, entre a prole de mães que receberam a planta, quando comparados aos filhotes pertencentes aos grupos controle.

Os resultados dos efeitos da administração de ração contendo $4 \%$ de sementes de S. occidentalis sobre os parâmetros hematológicos da prole de ratas gestantes são apresentados na tabela 41 e ilustrados na figura 28 . O número médio de eritrócitos (RBC) e leucócitos (WBC) e os valores médios de hemoglobina $(\mathrm{Hb})$, hematócrito (HCT), volume corpuscular médio (VCM), hemoglobina corpuscular média (HCM) e concentração de hemoglobina corpuscular média ( $\mathrm{CHCM}$ ) são apresentados. A análise estatística revelou haver diferença significante $(p<0,05)$, nos seguintes parâmetros, entre machos e fêmeas: no $\operatorname{VCM}\left(F_{\text {MACHOS }}=44,76\right.$; $F_{\text {FÊMEAS }}=$ 60,49; $d f=2 / 27)$, na HCM $\left(F_{\text {MACHOS }}=12,79 ; F_{\text {FÊMEAS }}=5,924, d f=2 / 27\right)$ e na $C H C M$ $\left(F_{\text {MACHOS }}=20,50 ; F_{\text {FÊMEAS }}=9,516, d f=2 / 27\right)$ A aplicação do teste de Dunnett apontou 
aumento significante $(p<0,05)$, no VCM e diminuição na HCM e na $C H C M$, nos animais pertencentes ao grupo PF, quando comparados aos animais pertencentes ao grupo controle. Na contagem diferencial de leucócitos (tabela 42) nenhuma alteração significante $(p>0,05)$ foi observada no número de células, entretanto, as hemácias da prole do grupo PF, estavam macrocíticas e hipocrômicas, em comparação com as leituras realizadas nas lâminas da prole do grupo controle.

Os resultados obtidos na avaliação do peso relativo do baço e timo das proles de mães tratadas com sementes de So4 na ração são apresentados na tabela 43. A análise estatística apontou não haver diferença significante $(p>0,05)$, na avaliação destes parâmetros, entre as proles tratadas e seus respectivos grupos controle.

A tabela 44 mostra a celularidade do baço e medula óssea, da prole de ratas tratadas com $4 \%$ de sementes de $S$. occidentalis na ração. Assim, a análise estatística apontou não haver diferença significante $(p>0,05)$, entre os grupos.

Em relação ao estudo histopatológico de fragmentos histológicos provenientes do baço, timo, linfonodos, fígado e de diferentes porções do intestino, nenhuma alteração morfológica digna de nota foi observada em qualquer das amostras colhidas, de animais pertencentes aos diferentes grupos experimentais.

Em relação ao estudo histopatológico de fragmentos histológicos provenientes do timo, linfonodos, fígado e de diferentes porções do intestino, nenhuma alteração morfológica digna de nota foi observada em qualquer das amostras colhidas, de animais pertencentes aos diferentes grupos experimentais.

Por outro lado, a análise morfológica do baço dos animais tratados com $4 \%$ de sementes de $S$. occidentalis na ração apresentou: desorganização do parênquima esplênico, proliferação hematopoiética extramedular caracterizada pela 
incidência de progenitores eritróides em diferentes estágios de maturação e megacariócitos multinucleados (Figura 29). 
Tabela 39 - Peso médio (em g), da prole de ratas tratadas com 0 e $4 \%$ de sementes de S. occidentalis na ração e seu grupo peer-feeding (PF). Foram utilizados 10 animais por grupo. São apresentados as médias e os respectivos desvios padrões

\begin{tabular}{|c|c|c|c|c|c|c|}
\hline \multirow{3}{*}{$\begin{array}{c}\text { Dias pós - } \\
\text { nascimento }\end{array}$} & \multicolumn{6}{|c|}{ Senna occidentalis (\%) } \\
\hline & \multicolumn{2}{|c|}{0} & \multicolumn{2}{|c|}{4} & \multicolumn{2}{|c|}{ PF } \\
\hline & Machos & Fêmeas & Machos & Fêmeas & Machos & Fêmeas \\
\hline $2^{\circ}$ & $10,4 \pm 1,2$ & $9,4 \pm 1,5$ & $10,1 \pm 1,4$ & $8,8 \pm 1,6$ & $9,6 \pm 1,5$ & $9,7 \pm 1,7$ \\
\hline $4^{\circ}$ & $14,2 \pm 1,6$ & $12,7 \pm 1,2$ & $14,0 \pm 1,7$ & $12,1 \pm 1,6$ & $14,3 \pm 1,6$ & $13,2 \pm 1,7$ \\
\hline 6 & $17,7 \pm 2,0$ & $16,1 \pm 1,3$ & $17,6 \pm 1,5$ & $15,4 \pm 1,5$ & $17,8 \pm 1,8$ & $16,0 \pm 1,8$ \\
\hline 8 & $24,3 \pm 1,7$ & $19,0 \pm 1,2$ & $24,0 \pm 1,7$ & $18,0 \pm 1,6$ & $24,5 \pm 2,9$ & $18,0 \pm 1,8$ \\
\hline 10 & $27,1 \pm 2,4$ & $21,3 \pm 1,4$ & $26,2 \pm 1,3$ & $21,2 \pm 1,7$ & $26,8 \pm 3,1$ & $21,7 \pm 1,8$ \\
\hline 12 & $30,5 \pm 2,5$ & $24,7 \pm 2,1$ & $29,2 \pm 2,2$ & $24,8 \pm 1,8$ & $29,1 \pm 3,4$ & $26,8 \pm 2,2$ \\
\hline 14 & $33,3 \pm 2,4$ & $30,2 \pm 1,7$ & $32,6 \pm 2,1$ & $30,4 \pm 2,1$ & $31,7 \pm 3,6$ & $30,6 \pm 1,0$ \\
\hline 16 & $36,4 \pm 1,6$ & $35,1 \pm 2,0$ & $36,1 \pm 2,5$ & $35,6 \pm 2,8$ & $35,5 \pm 3,3$ & $36,2 \pm 2,2$ \\
\hline $18^{\circ}$ & $41,0 \pm 2,3$ & $40,5 \pm 2,3$ & $39,6 \pm 2,5$ & $40,6 \pm 2,3$ & $40,5 \pm 3,2$ & $40,7 \pm 2,3$ \\
\hline $20^{\circ}$ & $54,3 \pm 4,0$ & $46,4 \pm 3,3$ & $52,5 \pm 3,1$ & $48,3 \pm 1,7$ & $52,9 \pm 3,6$ & $46,5 \pm 3,0$ \\
\hline $21^{\circ}$ & $77,4 \pm 1,3$ & $72,2 \pm 4,5$ & $75,1 \pm 3,2$ & $74,1 \pm 2,5$ & $76,9 \pm 3,0$ & $71,5 \pm 2,5$ \\
\hline
\end{tabular}


Tabela 40 - Peso semanal e total (em g), da prole de ratas tratadas com 0 e $4 \%$ de sementes de $S$. occidentalis na ração e seu grupo peer-feeding (PF). Foram utilizados 10 animais por grupo. São apresentados as médias e os respectivos desvios padrões

\begin{tabular}{|c|c|c|c|c|c|c|}
\hline \multirow{3}{*}{$\begin{array}{c}\text { Dias pós - } \\
\text { nascimento }\end{array}$} & \multicolumn{6}{|c|}{ Senna occidentalis (\%) } \\
\hline & \multicolumn{2}{|c|}{0} & \multicolumn{2}{|c|}{4} & \multicolumn{2}{|c|}{ PF } \\
\hline & Machos & Fêmeas & Machos & Fêmeas & Machos & Fêmeas \\
\hline Semana 1 & $4,6 \pm 1,9$ & $3,2 \pm 1,1$ & $4,6 \pm 2,0$ & $3,7 \pm 1,4$ & $4,9 \pm 1,7$ & $4,7 \pm 1,6$ \\
\hline Semana 2 & $3,1 \pm 1,3$ & $4,6 \pm 1,2$ & $3,2 \pm 1,6$ & $4,8 \pm 1,6$ & $3,9 \pm 1,5$ & $4,8 \pm 1,7$ \\
\hline Semana 3 & $18,2 \pm 2,0$ & $15,8 \pm 1,3$ & $17,7 \pm 1,5$ & $16,7 \pm 1,5$ & $18,2 \pm 1,8$ & $15,4 \pm 1,8$ \\
\hline Total & $7,4 \pm 1,7$ & $6,8 \pm 1,2$ & $7,4 \pm 1,7$ & $7,1 \pm 1,6$ & $7,5 \pm 2,9$ & $6,7 \pm 1,8$ \\
\hline
\end{tabular}


Tabela 41 - Número médio de eritrócitos $\left(x 10^{6} / \mathrm{mm}^{3}\right)$ e leucócitos $\left(x 10^{6} / \mathrm{mm}^{3}\right)$ e os valores médios do hematócrito - HCT $(\%)$ e hemoglobina - $\mathrm{Hb}(\mathrm{g} / \mathrm{dL})$, volume corpuscular médio - VCM $\left(\mu^{3}\right)$, hemoglobina corpuscular média - HCM $(\mu \mu \mathrm{g})$ e concentração de hemoglobina corpuscular média - $\mathrm{CHCM}(\%)$, da prole de ratas tratadas com 0 e $4 \%$ de sementes de $S$. occidentalis na ração e seu grupo peer-feeding (PF). Foram utilizados 10 animais por grupo. São apresentados as médias e os respectivos desvios padrões

\begin{tabular}{|c|c|c|c|c|c|c|}
\hline \multirow{3}{*}{$\begin{array}{c}\text { Grupos } \\
\text { Gênero da prole }\end{array}$} & \multicolumn{6}{|c|}{ Senna occidentalis (\%) } \\
\hline & \multicolumn{2}{|c|}{0} & \multicolumn{2}{|c|}{4} & \multicolumn{2}{|c|}{ PF } \\
\hline & Machos & Fêmeas & Machos & Fêmeas & Machos & Fêmeas \\
\hline \multicolumn{7}{|l|}{ Parâmetros } \\
\hline Eritrócitos $\left(\times 10^{6} / \mathrm{mm}^{3}\right)$ & $5,0 \pm 0,46$ & $4,9 \pm 0,25$ & $4,9 \pm 0,36$ & $4,6 \pm 1,1$ & $4,8 \pm 0,36$ & $4,7 \pm 0,30$ \\
\hline Leucócitos $\left(\times 10^{6} / \mathrm{mm}^{3}\right)$ & $2,1 \pm 0,40$ & $2,0 \pm 1,3$ & $2,2 \pm 0,44$ & $2,1 \pm 0,83$ & $2,0 \pm 0,27$ & $2,0 \pm 0,22$ \\
\hline HCT (\%) & $30,6 \pm 3,0$ & $29,2 \pm 1,4$ & $30,8 \pm 2,7$ & $27,3 \pm 3,7$ & $31,1 \pm 2,5$ & $28,6 \pm 2,9$ \\
\hline $\mathrm{Hb}(\mathrm{g} / \mathrm{dL})$ & $10,1 \pm 0,68$ & $9,9 \pm 0,37$ & $9,9 \pm 0,60$ & $9,2 \pm 2,0$ & $10,0 \pm 0,31$ & $10,1 \pm 0,60$ \\
\hline $\operatorname{VCM}\left(\mu^{3}\right)$ & $60,6 \pm 1,8$ & $60,2 \pm 1,4$ & $62,0 \pm 1,8$ & $61,5 \pm 1,7$ & $68,2 \pm 1,0^{a}$ & $67,3 \pm 2,0^{2}$ \\
\hline $\mathrm{HCM}(\mu \mu \mathrm{g})$ & $20,1 \pm 0,54$ & $20,6 \pm 0,38$ & $20,1 \pm 0,83$ & $20,1 \pm 1,6$ & $18,0 \pm 1,7^{\mathrm{a}}$ & $18,2 \pm 1,7^{a}$ \\
\hline CHCM (\%) & $33,2 \pm 0,97$ & $33,6 \pm 0,43$ & $32,3 \pm 0,77$ & $32,5 \pm 1,2$ & $27,5 \pm 3,6^{a}$ & $27,6 \pm 2,7^{\circ}$ \\
\hline
\end{tabular}

${ }^{a}$ difere significantemente $(p<0,05)$ em relação ao controle $(0 \%)$ - (ANOVA, seguida de Dunnett). 
MACHOS
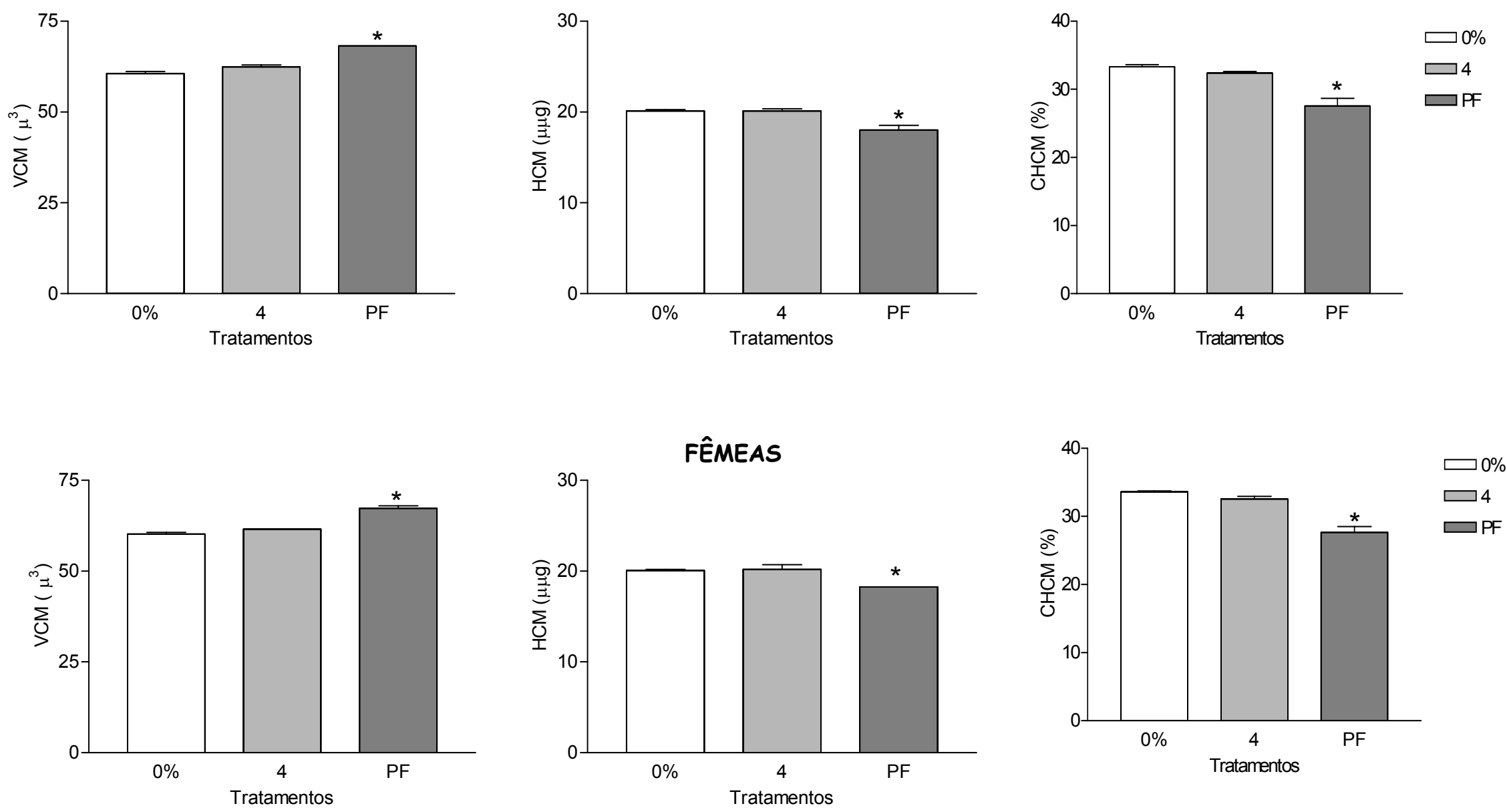

* difere significantemente $(p<0,05)$ em relação ao controle $(0 \%)$ - (ANOVA, seguida de Dunnett).

Figura 28 - Valor do volume corpuscular médio - VCM $\left(\mu^{3}\right)$, hemoglobina corpuscular média - HCM $(\mu \mu \mathrm{g})$ e concentração de hemoglobina corpuscular média - $\mathrm{CHCM} \mathrm{( \% ),} \mathrm{da} \mathrm{prole} \mathrm{de} \mathrm{ratas} \mathrm{tratadas} \mathrm{com} 0$ e $4 \%$ de sementes de S. occidentalis na ração e seu grupo peer-feeding (PF). Foram utilizados 10 animais por grupo. São apresentados as médias e os respectivos desvios padrões 
Tabela 42 - Média do número de linfócitos (em \%), neutrófilos segmentados (em\%), eosinófilos (em \%), bastonete (em \%) e monócitos (em \%), da prole de ratas tratadas com 0 e $4 \%$ de sementes de S. occidentalis na ração e seu grupo peerfeeding (PF). Foram utilizados 10 animais por grupo. São apresentados as médias e os respectivos desvios padrões

\begin{tabular}{lcccccc}
\hline \multicolumn{1}{c}{ Grupos } & \multicolumn{5}{c}{ Senna occidentalis (\%) } \\
\multicolumn{1}{c}{ Gênero da prole } & Machos & Fêmeas & Machos & Fêmeas & Machos & FFêmeas \\
\hline \multicolumn{1}{c}{ Parâmetros } & & & & & & \\
\hline Linfócitos (\%) & $68,0 \pm 0,9$ & $69,0 \pm 1,0$ & $68,0 \pm 1,0$ & $68,0 \pm 0,5$ & $67,0 \pm 1,0$ & $67,0 \pm 0,9$ \\
Neutrófilos (\%) & $26,0 \pm 0,1$ & $25,0 \pm 0,4$ & $28,0 \pm 0,3$ & $26,0 \pm 0,2$ & $27,0 \pm 04$ & $28,0 \pm 0,5$ \\
Eosinófilos (\%) & $1,0 \pm 0,1$ & $1,0 \pm 0,1$ & $1,0 \pm 0,1$ & $1,0 \pm 0,1$ & $1,0 \pm 0,1$ & $1,0 \pm 0,1$ \\
Bastonetes (\%) & $2,0 \pm 0,2$ & $2,0 \pm 0,1$ & $1,0 \pm 0,2$ & $2,0 \pm 0,3$ & $2,0 \pm 0,4$ & $2,0 \pm 0,3$ \\
Monócitos (\%)) & $3,0 \pm 0,4$ & $3,0 \pm 0,4$ & $2,0 \pm 0,4$ & $3,0 \pm 0,4$ & $3,0 \pm 0,4$ & $2,0 \pm 0,4$ \\
\hline
\end{tabular}


Tabela 43 - Peso relativo do baço e timo (g/ $100 \mathrm{~g} \mathrm{pv})$, da prole de ratas tratadas com 0 e $4 \%$ de sementes de $S$. occidentalis na ração e seu grupo peer-feeding (PF). Foram utilizados 10 animais por grupo. São apresentados as médias e os respectivos desvios padrões

\begin{tabular}{|c|c|c|c|c|c|c|}
\hline \multirow{3}{*}{$\begin{array}{c}\text { Grupos } \\
\text { Gênero da prole }\end{array}$} & \multicolumn{6}{|c|}{ Senna occidentalis (\%) } \\
\hline & \multicolumn{2}{|c|}{0} & \multicolumn{2}{|c|}{4} & \multicolumn{2}{|c|}{ PF } \\
\hline & Machos & Fêmeas & Machos & Fêmeas & Machos & Fêmeas \\
\hline \multicolumn{7}{|l|}{ Órgãos } \\
\hline baço & $0,435 \pm 0,17$ & $0,553 \pm 0,04$ & $0,551 \pm 0,06$ & $0,551 \pm 0,07$ & $0,464 \pm 0,26$ & $0,497 \pm 0,27$ \\
\hline timo & $0,347 \pm 0,47$ & $0,333 \pm 0,42$ & $0,423 \pm 0,11$ & $0,310 \pm 0,13$ & $0,311 \pm 002$ & $0,288 \pm 0,02$ \\
\hline
\end{tabular}


Tabela 44 - Celularidade do baço e da medula óssea (x 10\% $/ \mathrm{cel}$ ), da prole de ratas tratadas com 0 e $4 \%$ de sementes de $S$. occidentalis na ração e seu grupo peer-feeding (PF). Foram utilizados 10 animais por grupo. São apresentados as médias e os respectivos desvios padrões

\begin{tabular}{|c|c|c|c|c|c|c|}
\hline \multirow{3}{*}{$\begin{array}{c}\text { Grupos } \\
\text { Gênero da prole }\end{array}$} & \multicolumn{6}{|c|}{ Senna occidentalis (\%) } \\
\hline & \multicolumn{2}{|c|}{0} & \multicolumn{2}{|c|}{4} & \multicolumn{2}{|c|}{ PF } \\
\hline & Machos & Fêmeas & Machos & Fêmeas & Machos & Fêmeas \\
\hline \multicolumn{7}{|l|}{ Órgãos } \\
\hline baço & $1,19 \pm 0,27$ & $0,993 \pm 0,19$ & $0,764 \pm 0,42$ & $0,812 \pm 0,17$ & $0,854 \pm 0,51$ & $0,820 \pm 0,53$ \\
\hline timo & $0,808 \pm 0,16$ & $1,062 \pm 0,20$ & $0,775 \pm 0,15$ & $1,180 \pm 0,48$ & $0,920 \pm 04$ & $1,470 \pm 0,09$ \\
\hline
\end{tabular}




\subsubsection{Experimento 7.2: avaliação do burst oxidativo e da fagocitose de neutrófilos por citometria de fluxo na prole de ratas tratadas com 0 e $4 \%$ de sementes de $S$. occidentalis na ração e seu grupo peer-feeding}

A tabela 45 mostra avaliação do burst oxidativo e da fagocitose de neutrófilos, por citometria de fluxo, da prole de ratas tratadas com 0 e $4 \%$ de sementes de S. occidentalis na ração e seu grupo peer-feeding. A análise de variância realizada revelou haver diferença significante $(p<0.05)$ entre os grupos, na fluorescência do burst basal $\left(\mathrm{F}_{\mathrm{MACHOS}}=5,648 ; \mathrm{F}_{\mathrm{FEEMEAS}}=8,141 ; \mathrm{df}=2 / 27\right)$, no burst induzido por SAPI $\left(F_{\text {MACHOS }}=5,972 ; F_{\text {FÊMEAS }}=4,834 ; 2 / 27\right)$, no burst induzido por $\mathrm{DCFH}\left(\mathrm{F}_{\mathrm{MACHOS}}=\right.$ 3,846; $F_{\text {FÊMEAS }}=8,141 ; d f=2 / 27$ ), bem como, na porcentagem de fagocitose $\left(F_{\text {MACHOS }}=0,576 ; F_{\text {FÊMEAS }}=2,074 ; d f=2 / 27\right)$ de neutrófilos. $A$ aplicação do teste de Dunnett mostrou haver aumento significante $(p<0,05)$, na fluorescência do burst basal, no burst induzido por SAPI e no burst induzido por DCFH; e diminuição na porcentagem de fagocitose, na prole de mães tratadas com So4, em relação aos animais do grupo controle. Este mesmo teste apontou ainda, aumento significante $(p<0,05)$, na florescência do burst induzido por SAPI e diminuição na porcentagem de neutrófilos que fagocitaram partículas de SAPI, naqueles animais pertencentes ao grupo PF, quando comparados aos ratos do grupo controle nos animais, (figura 30 e 31). 

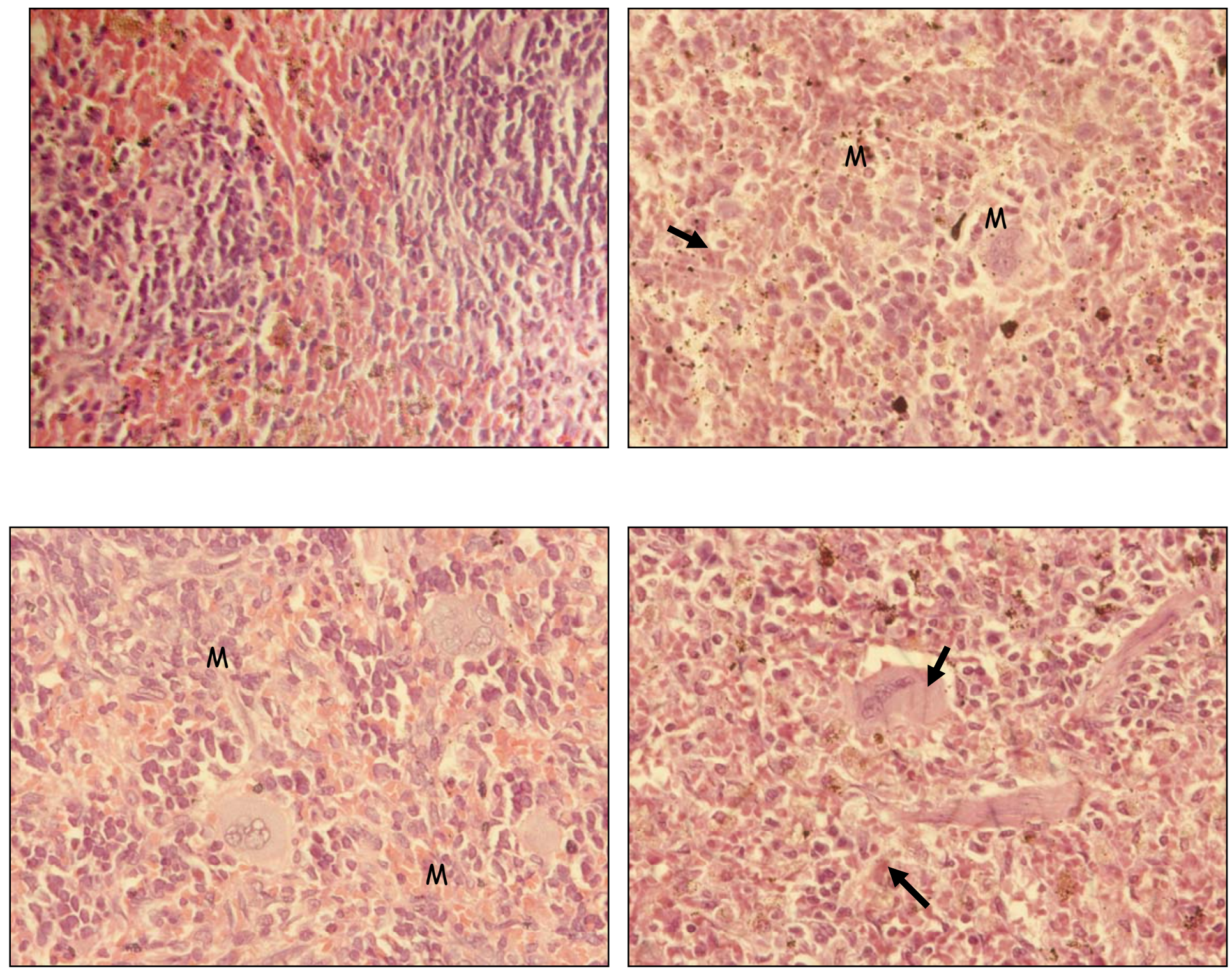

Figura 29 - Fotomicrográfia do baço de ratos recém-desmamados tratados durante 14 dias com sementes de $S$. occidentalis na ração. A. Integridade do parênquima esplênico com linfonodos bem delimitados, animal controle. B. Aumento do tamanho dos folículos linfóides e presença de megacariócitos (M), nos ratos do grupo So4\% (seta). C. Megacariócitos (M) visíveis com núcleo multilobulado e nucléolos proeminentes (seta), nos ratos do grupo So4\%. D. Progenitores eritróides em diferentes estágios de maturação (seta) nos ratos do grupo So4\%. (H.E. 40x) 
Tabela 45 - Avaliação do burst oxidativo e da fagocitose de neutrófilos, da prole de ratas tratadas com 0 e $4 \%$ de sementes de S. occidentalis na ração e seu grupo peer-feeding (PF). Foram utilizados 10 animais por grupo. São apresentados as médias e os respectivos desvios padrões

\begin{tabular}{|c|c|c|c|c|c|c|}
\hline \multicolumn{7}{|c|}{ Senna occidentalis } \\
\hline Grupos & \multicolumn{2}{|c|}{0} & \multicolumn{2}{|c|}{4} & \multicolumn{2}{|c|}{ PF } \\
\hline Gênero da Prole & Machos & Fêmeas & Machos & Fêmeas & Machos & Fêmeas \\
\hline \multicolumn{7}{|l|}{ Parâmetros } \\
\hline Burst basal & $56,4 \pm 22,3$ & $53,9 \pm 22,5$ & $86,3 \pm 18,0^{a}$ & $86,9 \pm 17,5^{a}$ & $80,8 \pm 19,0^{a}$ & $80,9 \pm 17,8^{a}$ \\
\hline Burst SAPI & $91,5 \pm 23,9$ & $99,5 \pm 21,4$ & $117,3 \pm 24,5^{a b}$ & $119,5 \pm 25,3^{a b}$ & $82,2 \pm 14,2$ & $82,9 \pm 12,9$ \\
\hline Burst PMA & $408,7 \pm 175,0$ & $327,2 \pm 202,2$ & $461,6 \pm 0,92$ & $452,4 \pm 85,3$ & $309,1 \pm 27,5$ & $315,9 \pm 30,1$ \\
\hline Burst DCFH & $57,7 \pm 21,9$ & $53,9 \pm 22,5$ & $82,6 \pm 19,4 \mathrm{ab}$ & $86,9 \pm 17,2^{a b}$ & $71,1 \pm 18,1$ & $80,9 \pm 17,8$ \\
\hline$\%$ Fagocitose ${ }^{\mathrm{c} 1}$ & $36,4 \pm 24,7$ & $25,3 \pm 6,2$ & $18,1 \pm 3,5^{a}$ & $17,1 \pm 2,3^{a}$ & $18,2 \pm 3,5^{a}$ & $17,7 \pm 2,7^{a}$ \\
\hline $\begin{array}{l}\text { Intensidade } \\
\text { fagocitose }\end{array}$ & $23,0 \pm 3,4$ & $22,5 \pm 3,4$ & $22,9 \pm 2,2$ & $22,5 \pm 2,5$ & $25,5 \pm 2,3$ & $25,9 \pm 1,8$ \\
\hline
\end{tabular}

Os dados representam a intensidade média de fluorescência (médias e os respectivos desvios padrões), correspondentes ao gate da população de neutrófilos sangüíneos.

${ }^{a}$ difere significantemente $(p<0,05)$ em relação ao controle $(0 \%)$ - (ANOVA,seguida de Dunnett).

${ }^{b}$ difere significantemente $(p<0,05)$ em relação ao PF (Teste "t" Student).

${ }^{c 1}$ porcentagem de neutrófilos que fagocitaram partículas de SAPI.

c2 quantidade de bactérias, que foram fagocitadas pela população de neutrófilos. Expressas pela média geométrica da intensidade de fluorescência da população de neutrófilos. 

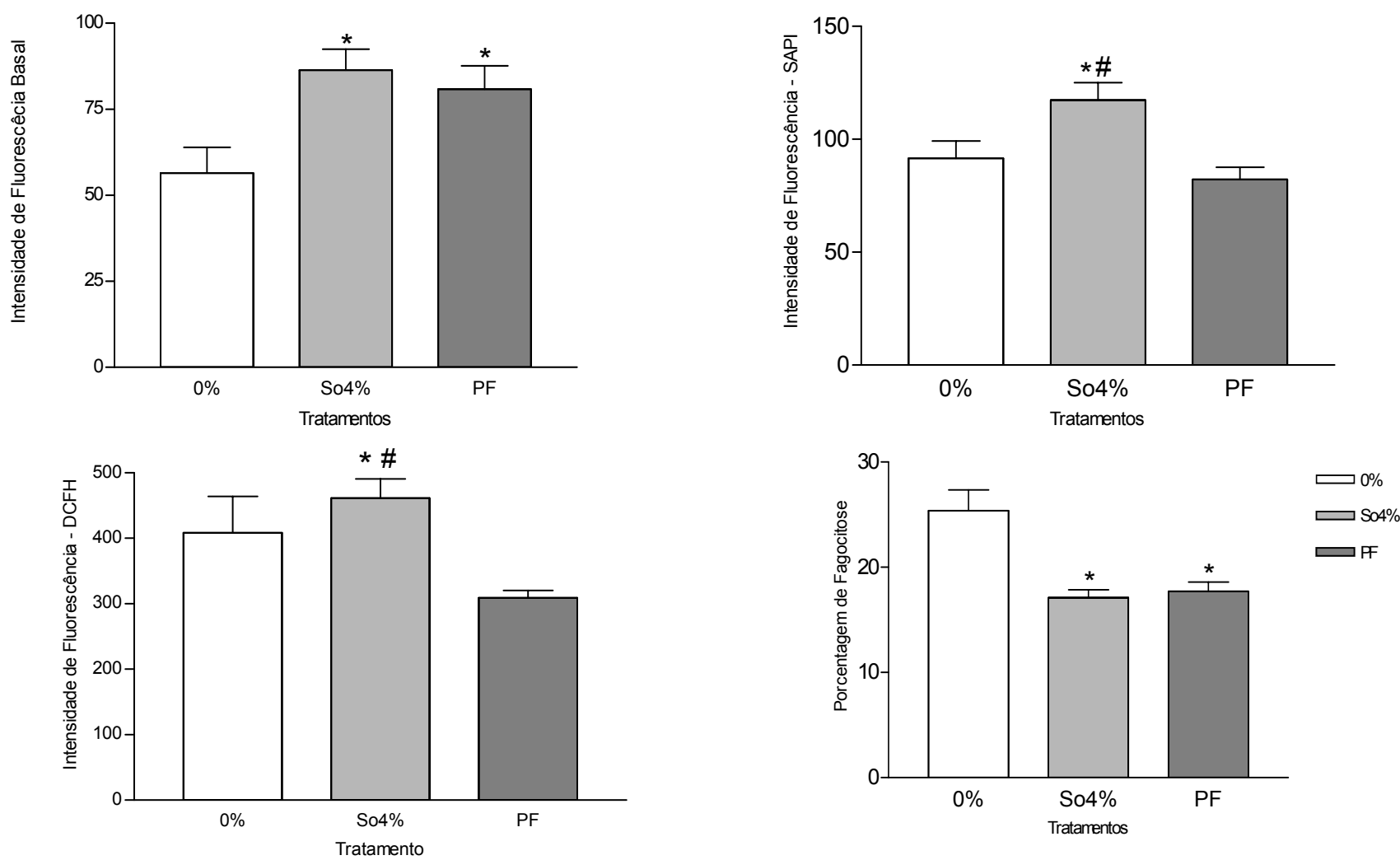

* difere significantemente $(p<0,05)$ em relação ao controle $(0 \%)$ - (ANOVA, seguida de Dunnett). \# difere significantemente $(p<0,05)$ do grupo PF (Teste "t" Student).

Figura 30 - Avaliação do burst oxidativo e da fagocitose de neutrófilos, de ratos machos, da prole de ratas tratadas com 0 e $4 \%$ de sementes de $S$. occidentalis na ração e seu grupo peer-feeding (PF). Foram utilizados 10 animais por grupo. São apresentados as médias e os respectivos desvios padrões 

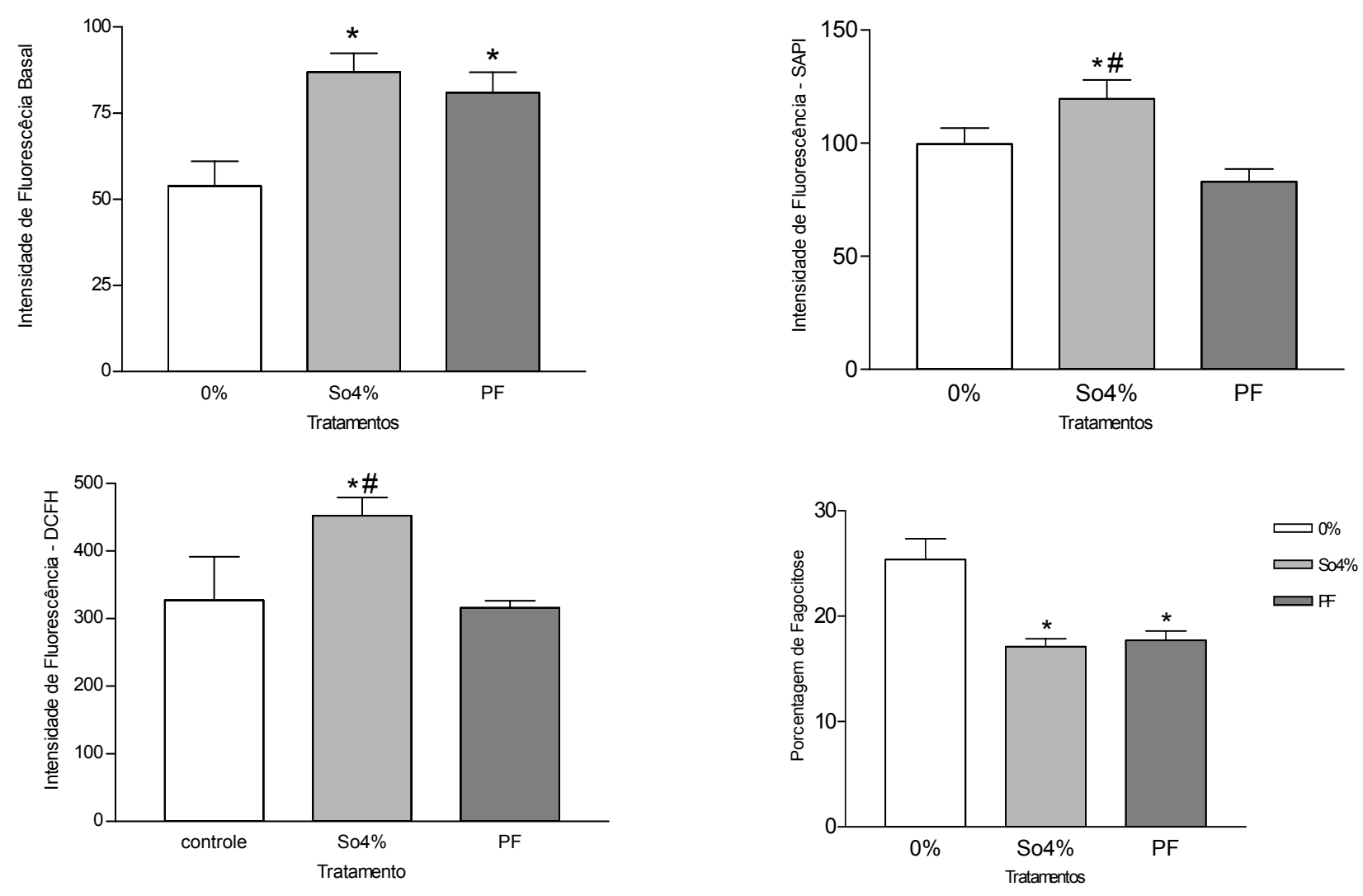

* difere significantemente $(p<0,05)$ em relação ao controle $(0 \%)$ - (ANOVA, seguida de Dunnett).

\# difere significantemente $(p<0,05)$ do grupo PF (Teste " $t$ " Student).

Figura 31 - Avaliação do burst oxidativo e da fagocitose de neutrófilos, de ratas fêmeas, da prole de ratas tratadas com 0 e $4 \%$ de sementes de $S$. occidentalis na ração e seu grupo peer-feeding (PF). Foram utilizados 10 animais por grupo. São apresentados as médias e os respectivos desvios padrões 


\subsubsection{Experimento 7.3: Avaliação da hipersensibilidade do tipo tardia a soro albumina bovina (BSA), na prole de ratas tratadas com 0 e $4 \%$ de sementes de s. occidentalis na ração e seu grupo peer-feeding}

A resposta celular adaptativa sobre a prole de ratas tratadas com 0 e $4 \%$ de sementes de $S$. occidentalis na ração e seu grupo peer-feeding, foi avaliada por meio do teste de hipersensibilidade tipo tardia (DTH), frente ao desafio com a Soro Albumina Bovina (BSA). A análise estatística revelou não haver diferença significante $(p>0,05)$ na evolução do edema induzido pela inoculação de $0,1 \mathrm{~mL}$ de BSA no coxim plantar na prole de ratas gestantes tratadas com a planta, quando comparados aos animais pertencentes ao grupo controle e peer-feeding, nos tempos 0, 4 e 24 horas de avaliação (Tabela 46). 
Tabela 46 - Medida do edema induzido pela inoculação de 0,1 ml de BSA no coxim plantar de ratas fêmeas, da prole de ratas tratadas com 0 e $4 \%$ de sementes de $S$. occidentalis na ração e seu grupo peer-feeding (PF). Foram utilizados 10 animais por grupo. São apresentados as médias e os respectivos desvios padrões

\begin{tabular}{|c|c|c|c|c|c|c|}
\hline \multicolumn{7}{|c|}{ Senna occidentalis } \\
\hline & \multicolumn{2}{|c|}{0} & \multicolumn{2}{|c|}{4} & \multicolumn{2}{|c|}{ PF } \\
\hline & Machos & Fêmeas & Machos & Fêmeas & Machos & Fêmeas \\
\hline \multicolumn{7}{|c|}{ Tempo em horas } \\
\hline 0 & $2,0 \pm 0,05$ & $1,9 \pm 0,03$ & $2,0 \pm 0,02$ & $1,9 \pm 0,02$ & $2,1 \pm 0,06$ & $2,0 \pm 0,05$ \\
\hline 4 & $4,3 \pm 0,2$ & $4,0 \pm 0,7$ & $4,4 \pm 0,8$ & $4,3 \pm 0,1$ & $4,5 \pm 0,8$ & $4,3 \pm 0,6$ \\
\hline 24 & $2,8 \pm 0,15$ & $2,5 \pm 0,18$ & $2,7 \pm 0,06$ & $2,3 \pm 0,11$ & $2,6 \pm 0,07$ & $2,4 \pm 0,04$ \\
\hline
\end{tabular}





\section{DISCUSSÃO}

Uma perda considerável do rebanho brasileiro tem suas causas na dificuldade de erradicação de plantas que podem causar intoxicação. Embora não haja estatísticas nacionais, especialistas da Embrapa Gado de Corte dizem ser significativo o percentual de mortes de bovinos no país causadas por sementes, folhas ou raízes com concentração elevada de elementos químicos que geram prejuízos à saúde dos animais (AFONSO; POTT, 2004). De fato, um levantamento isolado, ocorrido no Estado do Rio Grande do Sul, no ano de 2001 aponta que entre as causas de óbito de ruminantes, cerca de $10 \%$ são ocasionadas pela ingestão de plantas tóxicas, provocando a morte de aproximadamente 70 mil bovinos ao ano somente naquele Estado (RIET-CORREA; MEDEIROS, 2001).

Foi Steyn, em 1934, quem primeiro conceituou plantas tóxicas do ponto de vista agropecuário. Este pesquisador, em seu livro intitulado The toxicology of plants in South Africa propôs a seguinte definição "Uma planta tóxica ao animal é aquela que, quando ingerida naturalmente, por um período curto ou prolongado, causa efeitos nocivos à sua saúde ou mesmo a sua morte". Além disso, as debilidades físicas causadas pelos efeitos imunotóxicos de plantas podem deixá-los mais suscetíveis a outras doenças (RIET-CORREA et al., 1993; CHEEKE, 1998). Neste sentido, alguns autores citam como perdas econômicas significantes na criação animal aquelas advindas da imunodeficiência promovida pelas plantas tóxicas (RIET-CORREA et al., 1993; CHEEKE, 1998; TOKARNIA; DÖBEREINER; PEIXOTO, 2002; BOTHA; PENRITH, 2008). De fato, várias desordens no sistema imune estão relacionadas à toxicidade promovida pelas espécies vegetais, tanto em 
estudos realizados em condições naturais em animais de criação (IIZUKA et al., 2005; BOTHA; PENRITH, 2008; LEE et al., 2008), como aqueles experimentais, em animais de laboratório (HUEZA et al., 2005; DU, 2008; HUANG et al., 2008; FAKEYE et al., 2009).

Deve-se ainda considerar que o ser humano também pode estar exposto aos efeitos imunotóxicos de plantas, haja vista a utilização de plantas medicinais e preparações fitoterápicas que vem ocorrendo de forma indiscriminada e sem restrições. Neste sentido, uma busca na literatura científica mostra vários relatos de efeitos imunotóxicos no homem promovidos pelas fitotoxinas (CLOUATRE, 2004; OLIVEIRA; GONÇALVES, 2006).

Particularmente, em relação às intoxicações promovidas pela S. occidentalis, a literatura aponta que as perdas econômicas são bastante expressivas, uma vez que os animais intoxicados por esta planta desenvolvem anorexia, queda no ganho de peso e podem até mesmo vir a óbito, em casos de intoxicação aguda (SIMPSON et al., 1971; GRAZIANO et al., 1983; HERBERT et al., 1983).

De fato, tanto as intoxicações naturais, quanto as experimentais, vêm mostrando que animais de diferentes espécies, tais como suínos (TIMM; RIETCORREA; 1997), equinos (BARROS et al., 1990), ovinos (DOLLAHITE; HENSON, 1965), caprinos (BARBOSA-FERREIRA et al., 2008), leporinos (TASAKA et al., 2000), aves (HARAGUCHI et al., 1998) e ratos (WEG, 2001; BARBOSA-FERREIRA et al., 2005) apresentam alterações quando expostos a esta planta.

Além dos achados já descritos, como lesão hepática (IRIGOYEN et al., 1991), muscular (WEG, 2001) e cardíaca (BARROS, 1990), estudos realizados com frangos de corte, aos quais foram administradas baixas concentrações de sementes de $S$. 
occidentalis, sugerem que esta planta compromete a sua resposta imune especifica e inespecífica (SILVA et al., 2003; HUEZA et al., 2007).

Corroborando as pesquisas anteriores realizados em aves por Silva et al., (2003), verificou-se no estudo realizado em nossa Dissertação de Mestrado, utilizando-se ratos como sujeitos experimentais, que a $S$. occidentalis foi também capaz de promover efeitos imunotóxicos em mamíferos, sendo observadas alterações no timo, no baço e nos eritrócitos destes animais adultos tratados com as maiores concentrações de sementes da planta (2\% e 4\%) (MARIANO-SOUZA, 2005).

Portanto, o presente estudo complementa o trabalho anterior em ratos, analisando-se agora as alterações promovidas pela $S$. occidentalis na função de órgãos linfóides primários e secundários de animais recém-desmamados. Assim, como objetivo maior, propõe-se, por meio de ambas as pesquisas (aquela realizada no Mestrado e a presente), estabelecer um protocolo de avaliação do sistema imune em nosso laboratório, procurando, desta maneira, contribuir com o protocolo de imunotoxicidade que vem sendo preconizado pelas principais agências regulamentadoras internacionais, como: Organizantion For Economic Co-Operation and Development - OECD (2001), Food and Drug Administration - FDA (1999), Environmental Protection Agency - EPA (1996), European Medicine Agencie - EMEA (2006).

Inicialmente, o delineamento experimental estabelecido foi o de 14 dias de administração da planta aos animais recém-desmamados, utilizando as concentrações de $0 \%, 1 \%, 2 \%$ e $4 \%$, de sementes de S. occidentalis (So) na ração, de acordo com aquele estudo conduzido anteriormente na Dissertação de Mestrado, no qual foram utilizados ratos adultos, bem como em trabalho conduzido por 
Barbosa-Ferreira et al. (2005), também utilizando esta espécie animal (e faixa etária) como sujeito experimental.

Entretanto, nesta pesquisa também foram realizados experimentos com 28 dias de administração de sementes de $S$. occidentalis, já que no transcorrer deste trabalho, os dados obtidos apontaram que a administração desta planta por um período maior, permitiria melhor evidenciar as alterações que esta promove no sistema imune. Reforçaram também esta decisão os achados encontrados na literatura, mostrando que a administração de toxicantes por períodos maiores de tempo, mesmo em concentrações baixas, permitiria detectar os efeitos deletérios nos órgãos linfo-hematopoiéticos de animais jovens (BARROW; RAVEL, 2005; LADICS et al., 2005; ROTH et al., 2006; DIETERT; HOLSAPPLE, 2007; DIETERT, 2009). Desta forma, optou-se por aplicar o protocolo de administração durante os 28 dias naqueles animais jovens, tratados com a maior concentração da planta (4\%), pois foram nos animais deste grupo que as manifestações tóxicas mais relevantes foram observadas nos estudos precedentes.

Nestes experimentos utilizou-se também o grupo de animais peer-feeding (PF), pois embora a avaliação nos diferentes protocolos experimentais, de ratos provenientes do grupo So4, não tivesse revelado alterações significantes, seria necessário agora verificar se a restrição ao consumo de ração imposta aos animais do grupo PF por mais duas semanas, não provocaria efeito deletério.

Um dos fatores que pode interferir no ganho de peso dos animais expostos à S. occidentalis seria o fato desta planta não ser palatável, como já descrito por Mercer et al. (1967) e corroborado em trabalhos subsequentes (CALORE et al., 1998; TASAKA et al., 2000, TOKARNIA et al., 2002). Assim, devido a esta característica da planta, os animais ingeririam menor quantidade de alimento, o que 
levaria, conseqüentemente, à queda do peso. Por outro lado, o estudo conduzido por Barbosa-Ferreira et al. (2005) em ratos que receberam ração comercial e experimental com palatabilizante, permitiu sugerir que menor aceitação da planta pelos animais não seria a única responsável pela queda do consumo de ração, mas principalmente devido aos efeitos tóxicos da $S$. occidentalis per se, uma vez que aqueles ratos tratados com o palatabilizante associado à planta apresentaram queda significante no ganho de peso somente na $2^{\mathrm{a}}$ semana de exposição.

Da mesma maneira, verificou-se no presente estudo que a redução no consumo de ração foi mais evidente a partir da segunda semana de administração da S. occidentalis, o que sustenta a hipótese de que esta promova, de fato, anorexia. Além disso, tanto a intoxicação espontânea em animais domésticos (BARROS et al., 1990), quanto a intoxicação experimental em diferentes espécies animais (TASAKA et al., 2000; NADAL et al., 2003), confirmam que a anorexia é um achado comum na intoxicação pela S. occidentalis. Reforçam ainda esta conjectura, aqueles resultados obtidos com os animais do grupo PF no presente estudo, os quais apresentaram maior ganho de peso do que os animais tratados com So4.

Ainda, deve-se considerar que estudos conduzidos em humanos que utilizaram as espécies de Senna como laxante, objetivando a perda de peso, revelaram que a anorexia está associada ao consumo abusivo deste vegetal (STICKEL; SCHUPPAN, 2007; LIM; HOOKE; KERR, 2008; SOYUNCU, CETE; NOKAY, 2008).

Outra hipótese que poderia ser aventada em relação à perda de peso verificada naqueles animais tratados com as maiores concentrações de sementes de S. occidentalis, seria a produção de lesão intestinal causada pela planta, promovendo assim, a deficiência na absorção de nutrientes, como sugerida por 
Nadal et al. (2003) e observado nos estudos subseqüentes de Sossai, Nasone e Cantalamessa (2007). Contudo, o estudo histopatológico da mucosa intestinal daqueles animais que receberam as diferentes concentrações de S. occidentalis não mostrou quaisquer alterações sugestivas de injúria no epitélio gastrintestinal. Estes dados corroboram aqueles encontrados por Brusick e Menges (1997), que administraram a ratos a planta in natura e as frações dos derivados antranóides e não encontraram lesões no trato digestivo dos animais submetidos a ambos os tratamentos.

Outro fator relacionado à toxicidade da $S$. occidentalis e que poderia contribuir para a queda do ganho de peso é o seu efeito laxante, já que foram observadas fezes de consistência amolecida nos animais do grupo So4 a partir da segunda semana de tratamento no protocolo de 14 dias, bem como no décimo segundo dia de exposição nos estudos conduzidos por 28 dias. De fato, é amplamente conhecido que os antranóides, constituintes naturais da S. occidentalis, são agentes laxantes potentes (DE WITTE, 1993; JOO, 1998; FUKUDA et al., 2009), sendo esta a principal finalidade fitoterápica pela qual a planta vem sendo largamente utilizada (LENG-PESCHLOW, 1993; HEATON; CRIPPS, 1993; XING; SOFFER, 2001; SOYUNCU, CETE; NOKAY, 2008). Desta maneira, após os antranóides serem ingeridos, estes são biotransformados à custa do metabolismo bacteriano que libera dois metabólitos ativos, os quais apresentam mecanismos de ação independentes: a indução do aumento da motilidade intestinal e a alteração da absorção e secreção intestinal (VAN DER OHE et al., 1993; XING; SOFFER, 2001; SOSSAI; NASONE; CANTALAMESSA, 2007).

A lesão hepática produzida pela $S$. occidentalis é bem relatada em intoxicações espontâneas em bovinos (BARROS et al., 1990). De modo similar, 
intoxicações experimentais em diferentes espécies animais, como coelhos (TASAKA et al., 2000), cabras (SULIMAN; SHOMMEIN, 1986), frangos de corte (HARAGUCHI et al., 1998) e ratos (BARBOSA-FERREIRA et al., 2005), indicam que a hepatotoxicidade é um dos efeitos tóxicos associados à administração da $S$. occidentalis. Neste contexto, Beuers et al. (1991) sugerem que as antraquinonas presentes na planta seriam as responsáveis pela indução da hepatotoxicidade.

Como há estreita relação entre perda de peso e hepatotoxicidade (JACOBS; HIRSCH, 2000; STICKEL et al., 2000; CUI et al., 2008) e sabendo-se que a $S$. occidentalis promove efeito hepatotóxico, pode-se inferir que, associada às demais causas anteriormente apontadas, a perda de peso dos animais constatada neste trabalho também esteja relacionada a este efeito tóxico no fígado.

Vários estudos, particularmente em organismos jovens, tanto em humanos (DE ONIS, 2000; BAE; PESTKA, 2009), quanto em animais (BOTHA; PENRITH, 2008; ORTIZ et al., 2008) vêm demonstrando que as ações tóxicas promovidas pelos xenobióticos durante as fases de proliferação e diferenciação de células imunocompetentes, comprometem o funcionamento do sistema imune.

De fato, o sistema imune é um alvo potencial para os efeitos nocivos dos xenobióticos devido a sua dispersão em diferentes órgãos e tecidos (DE JONG; VAN LOVEREN, 2007). No que diz respeito ao desenvolvimento do sistema hematopoiético, a produção constante de células progenitoras, responsáveis pelas linhagens efetoras do sistema imune, ocorre na medula óssea e são dependentes do microambiente hematopoiético (REBAR, 1993. BORELLI et al., 2004; ELMORE, 2006). Neste contexto, as desordens sistêmicas que envolvem um tecido ou órgão particular, geralmente refletem as manifestações anormais do tecido sanguíneo, incluindo supressão ou estimulação da função da medula óssea, aumento, 
destruição ou seqüestro das células sanguíneas, bem como hemodiluição e sangramentos (SPIVAK, 2000).

A presente pesquisa revelou diminuição na contagem global de células da medula óssea em ratos recém-desmamados provenientes dos grupos So2 e So4 e expostos à planta durante 14 dias. Por outro lado, os dados obtidos na Dissertação de Mestrado, utilizando-se este mesmo protocolo experimental em animais adultos, não revelaram toxicidade (MARIANO-SOUZA, 2005). Portanto, os resultados obtidos e aqui apresentados permitem sugerir que há maior vulnerabilidade do tecido hematopoiético aos efeitos tóxicos da planta nos ratos jovens. A atual investigação também mostrou haver alterações nos animais recém-desmamados, tratados durante 28 dias com So4, mas não em ratos adultos tratados pelo mesmo período de tempo (dados não publicados).

Embora a literatura não elucide completamente esta maior sensibilidade do sistema hematopoiético de organismos jovens às injúrias tóxicas, uma possível hipótese para explicá-la é o fato de que as fases de colonização, maturação e estabelecimento da medula óssea como microambiente exclusivo para a produção de células mielóides e linfóides ocorrem durante os primeiros trinta dias de vida pósnatal (LANDRETH, 2002).

Ainda, no que se refere ao sistema hematopoiético, sabe-se que perturbações hemostáticas que interfiram nos mecanismos de transporte, ligação, incorporação do ferro, bem como em seus estoques, além de estados de inflamação, infecção, sangramentos e exposição a drogas e toxinas, levam a quadros de anemias hipoproliferativas (SPIVAK, 2000). A anemia hipoproliferativa, caracterizada pela redução dos valores de hemoglobina $(\mathrm{Hb})$, da Hemoglobina Corpuscular Média (HCM), do Volume Corpuscular Médio (VCM) e da Concentração de Hemoglobina 
Corpuscular Média ( $\mathrm{CHCM}$ ) é denominada de anemia microcítica e hipocrômica (SANTOS; MONTEIRO, 2008; PILNY, 2008).

A análise conjunta destes índices hematimétricos é útil para determinar a causa da anemia hipoproliferativa em questão. Neste sentido, o diagnóstico de hipocromia é determinado com base na redução dos parâmetros de $\mathrm{HCM}$ e CHCM (SANTOS; MONTEIRO, 2008). Também, a redução da HCM é sugestiva de deficit de oxigênio em todos os órgãos, sendo que os mais afetados nesta condição são o sistema nervoso central, o coração e os músculos, devido à alta demanda de oxigênio requerida por esses sistemas (AKBAS et al., 2005; PETTERINO; ARGENTINO-STORINO, 2006). Por outro lado, as alterações relacionadas ao VCM são sugestivas de falhas na maturação e na divisão das células progenitoras dos eritrócitos (KEIL et al., 2004; SANTOS; MONTEIRO, 2008).

A ocorrência de anemia microcítica e hipocrômica foi comum, tanto nos dados provenientes da Dissertação de Mestrado, quanto nos aqui encontrados, seja nos animais recém-desmamados e tratados durante 14 dias com So4, seja naqueles que receberam a S. occidentalis por 28 dias. Esses dados relativos à ocorrência de anemia coincidem com aqueles observados em aves (NAKAGE et al. 2000), bem como em ratos tratados com diferentes concentrações de sementes de $S$. occidentalis (ADAM et al., 2001; AL-YAHYA; AL-FARHAN; ADAM, 2002).

Vários são os estudos que, utilizando a microscopia eletrônica, relatam os danos mitocondriais em fibras musculares promovidos pela administração de $S$. occidentalis (GRAZIANO et al., 1983; CALORE et al.,1997; HARAGUCHI et al., 1998; TASAKA et al., 2000). Deste modo, estes autores sugeriram que a miopatia seria uma causa secundária relacionada aos efeitos tóxicos promovidos pela planta na função das mitocôndrias. Posteriormente, Hueza et al. (2007) propuseram que os 
princípios ativos da $S$. occidentalis induziriam à ativação das caspases pela via mitocondrial, levando à liberação da citocromo c, desencadeando assim, uma série de reações que iniciam a apoptose.

Dentre esses princípios ativos, a diantrona, uma antraquinona presente na $S$. occidentalis, poderia interferir negativamente no metabolismo das mitocôndrias dos precursores eritróides presentes na medula óssea, acarretando desordens na linhagem eritropoiética, induzindo à anemia microcítica e hipocrômica aqui verificada naqueles ratos do grupo So4. Neste sentido, sabe-se que durante a fase inicial da eritropoiese as células eritróides são nucleadas, sintetizam proteínas e suas reações oxidativas são dependentes das mitocôndrias; ao migrarem da medula óssea para os tecidos, e quando fisiologicamente maduras, estes anexos celulares tornam-se inexistentes (CIMEN, 2008). Desta maneira, uma teoria que poderia ser levantada para justificar este achado seria de que a alteração mitocondrial produzida pela antraquinona levaria ao quadro de anemia verificada nos animais expostos à $S$. occidentalis.

Por outro lado, os dados hematológicos obtidos no presente estudo permitem sugerir que a causa principal da diminuição da celularidade da medula óssea, seria a toxicidade indireta produzida pela $S$. occidentalis no sistema hematopoiético. Desta maneira, a anemia encontrada pode ser considerada uma resposta inicial às injúrias promovidas pela S. occidentalis sobre as células deste sistema. De fato, sabe-se que as desordens promovidas pelos xenobióticos na medula pertencem a classificações que seguem padrões distintos (KRISHNAN; PELEKIS, 1995; ABATAN; LATEEF; TAIWO, 2006; CHURIN et al., 2008). Se a alteração produzida pela S. occidentalis fosse devida à toxicidade direta do princípio ativo tóxico contido na mesma, as manifestações nas células do sangue periférico dos animais tratados 
seriam caracterizadas por pancitopenia e desvio à esquerda (presença de formas imaturas na circulação). Contrariamente, na toxicidade indireta, como aquela aqui sugerida, geralmente observa-se anemia ou desordens associadas às disfunções nas células dos órgãos linfóides primários e secundários (ABATAN; LATEEF; TAIWO, 2006; CHURIN et al., 2008).

Deve-se considerar ainda que as manifestações tóxicas sobre as células do sistema hematopoiético, especialmente nas linhagens eritróides, levam a mudanças críticas no citoesqueleto e, quando estes eritrócitos estão circulantes, estas mudanças favorecem o aumento do seqüestro destas células pelo baço (PAULUHN, 2004). Em relação a este órgão, sabe-se que em algumas espécies como o rato, o baço possui a capacidade de remover, de maneira efetiva, células degeneradas, eritrócitos senis, bem como materiais particulados e bactérias circulantes da corrente sanguínea. Estes atributos tornam o baço um órgão-alvo para toxicidade direta e indireta (SUTTIE, 2006). Deste modo, parâmetros gerais, como o peso relativo deste órgão, possuem papel importante como indicador primário da ocorrência de imunotoxicidade direta (DE JONG; VAN LOVEREN, 2007).

No presente estudo, verificou-se aumento do peso relativo do baço de ratos recém-desmamados dos grupos So2 e So4, expostos durante 14 e 28 dias, respectivamente. Entretanto, estes achados não foram observados nos animais adultos tratados por 14 dias. Uma hipótese que poderia justificar esta alteração naqueles animais recém-desmamados seria a ocorrência de proliferação hematopoiética extramedular. Assim, sabe-se que em condições normais o baço de roedores contribui em $10 \%$ para a hematopoiese esplênica; entretanto, quando exposto a hematotoxicantes este órgão passa a responder por $80 \%$ da produção 
total de eritrócitos, sendo esta produção e divisão seis vezes superior à produção promovida pela medula óssea (PAULUHN, 2004).

De acordo com Tenedini et al. (2004), a proliferação hematopoiética extramedular nas desordens neoplásicas mieloproliferativas é caracterizada pela predominância da hipercelularidade de progenitores mielóides indiferenciados e aumento de megacariócitos. Os achados morfológicos aqui obtidos sugerem que a toxicidade promovida pela S. occidentalis tenha induzido mudanças compatíveis com as desordens mieloproliferativas. De fato, estudos conduzidos com diferentes xenobióticos, como o vanádio (GONZALEZ-VILLALVA et al., 2006), acrilamida (HAO et al.,2006) e anilina (FORTOUL et al., 2008), apontam que a incidência de esplenomegalia, plaquetas gigantes e a ocorrência de hematopoiese extramedular, são compatíveis às desordens mieloproliferativas. Estas desordens estão relacionadas com o comprometimento da enzima mitocondrial heme-oxigenase, responsável pelo controle das espécies reativas de oxigênio (ROS) na biosíntese de heme (RYTER; TYRRELL, 2000). Assim, o aumento ou diminuição das ROS durante esta síntese, podem interferir no número de receptores e nos genes que coordenam as etapas de sinalização, mitose e transcrição, contribuindo para a maturação e produção ineficiente dos eritrócitos e megacariócitos.

Portanto, uma hipótese que poderia justificar esta alteração nos ratos recémdesmamados seria a de que o aumento deste órgão seja uma resposta à injúria indireta da S. occidentalis sobre o tecido hematopoiético, em particular sobre os eritrócitos. Assim, estas células seriam removidas da circulação e destruídas no baço, refletindo no aumento da atividade do órgão e, conseqüentemente, no aumento do seu tamanho. Considerando o exposto sobre este órgão, sabe-se que a integridade do citoesqueleto e o tamanho da hemácia são fatores relevantes para o 
resgate desta célula pelo sistema reticulo endotelial do baço (FORTOUL et al., 2008). No estudo morfológico deste órgão em ratos recém-desmamados e tratados com So4, que apresentaram anemia, verificou-se a presença de siderócitos. Os siderócitos são células caracterizadas pela substituição da proteína heme pelo ferro, e estão relacionados ao aumento da eritroclasia e do catabolismo da heme no baço, devido a distúrbios na síntese desta proteína (PAULUHN, 2004).

Seguindo-se esta linha de raciocínio, seria de se esperar que os resultados aqui obtidos revelassem a redução de eritrócitos circulantes, pelo menos naqueles animais recém-desmamados, que apresentaram alteração no peso relativo do baço; no entanto, tal achado não foi encontrado. Por outro lado, deve-se considerar que os eritrócitos possuem meia-vida longa na circulação - cerca de 60 dias (PILNY, 2008); como o tratamento com a $S$. occidentalis nesta pesquisa se estendeu por até no máximo um mês, pode-se sugerir que aqueles animais pertencentes aos grupos que receberam a planta não manifestaram tal alteração porque não houve tempo hábil para que este efeito ocorresse.

As células do timo são parte integrante do sistema imune primário e são provenientes de células progenitoras linfóides, as quais têm sua origem na medula óssea. Além disso, estas células progenitoras são aquelas responsáveis pela manutenção do tamanho e da celularidade do órgão (GILL et al., 2003; PELAYO et al., 2005; DRELA, 2006). Portanto, levando em consideração a toxicidade promovida pela administração de sementes de $S$. occidentalis na medula óssea dos animais recém-desmamados tratados com So2 e So4, é factível supor que desordens desta natureza comprometeriam a integridade das células do timo nestes animais. Esta constatação já foi observada anteriormente em nossa Dissertação de Mestrado, em ratos adultos, tratados com as maiores concentrações de sementes da planta $(2 \%$ e 
$4 \%$ ), os quais apresentaram redução, tanto no peso relativo, como no tamanho do timo. Além disso, sabendo-se que a região cortical e medular do timo estão relacionadas, respectivamente, à proliferação e maturação de células T e à geração e seleção de células T competentes (DRELA, 2006; DI ROSA, 2009) e que os dados provenientes de nossa Dissertação de Mestrado mostraram, por meio da análise histomorfométrica do órgão, depleção de ambas regiões do timo (MARIANOSOUZA, 2005), pode-se teorizar que a intoxicação produzida pela $S$. occidentalis poderia acarretar em comprometimento da resposta imune específica.

Na presente investigação, avaliou-se ainda a resposta imune celular do tipo tardia, mediada por linfócitos T-helper 1 (Th1). No estudo precedente, a avaliação da evolução do edema inflamatório agudo às 4 horas, utilizando-se como agente flogístico a carragenina, essa resposta foi comprometida em ratos adultos tratados com a S. occidentalis (MARIANO-SOUZA, 2005). Porém, ao contrário do verificado anteriormente, não foram observadas alterações na evolução do edema inflamatório agudo e na resposta imune celular do tipo tardia, em nenhum dos animais dos diferentes grupos avaliados. Assim, os dados obtidos na presente pesquisa sugerem haver o comprometimento destas células efetoras da resposta imune inata.

De acordo com Carvalho (2004), embora os fagócitos sejam as principais células efetoras da resposta imune inata, no processo inflamatório agudo, a plena atividade destas células é dependente da ativação pelo Interferon Gama (IFN- $\chi$ ), produzido pelas células Th1. Portanto, reunindo-se os resultados obtidos em ambas as pesquisas (isto é, na Dissertação de Mestrado e na presente), em relação à avaliação dos órgãos linfóides primários e secundários, tanto nos ratos adultos, quanto nos jovens, é possível sugerir que a toxicidade promovida pela $S$. 
occidentalis sobre as células progenitoras da medula óssea, seja a principal responsável pelo acometimento destes órgãos.

Um fator fundamental e que deve ser sempre considerado quando se estuda imunotoxicidade, é o relevante impacto que a má nutrição pode produzir no tamanho dos órgãos linfóides, particularmente do timo (PRENTICE, 1999; SAVINO, 2002; DRELA, 2006). De acordo com a pesquisa realizada por Silva et al. (2003), em aves, as alterações encontradas na Bursa de Fabricius e no timo, estariam associadas a deficiência nutricional e não aos efeitos tóxicos promovidos pela S. occidentalis. De fato, foi observada redução no consumo de ração por aqueles ratos tratados com as sementes da planta. Assim, para avaliar o impacto deste fator nos órgãos linfóides destes animais, acrescentou-se o grupo PF, o qual foi composto por animais que ingeriram a mesma quantidade de ração que aqueles tratados com So4. No entanto, de todas as avaliações realizadas nestes animais PF, encontrou-se como alteração apenas a diminuição no peso relativo do timo.

Portanto, ao contrário do que observado em aves, parece que a provável desnutrição, devido ao menor consumo de ração, não foi um fator preponderante para justificar as alterações produzidas pela S. occidentalis. Portanto, pode-se inferir que, se há alguma alteração no sistema imune produzido pelo menor consumo de ração, esta se deve à ação conjunta do efeito produzido pela(s) toxina(s) da planta per se.

Nos estudos de imunotoxicidade também são avaliadas as células envolvidas diretamente na resposta imune inata, como os macrófagos, já que são várias as pesquisas que evidenciam claramente a ação de imunotóxicos sobre o metabolismo destas células, levando a perturbações nos mecanismos primários de defesa, como por exemplo, na produção das espécies reativas de oxigênio (SAKURAI; OHTA; 
FUJIWARA, 2005; KOVACIC; THURN, 2005; HUEZA et al., 2007; KOVACIC; SOMANATHAN, 2008).

O processo de fagocitose compreende: aderência tecidual, quimiotaxia, ingestão ou fagocitose de partículas estranhas e destruição do patógeno pela produção intracelular de radicais livres como o ânion superóxido e outras ROS, localizadas nos fagossomos destas células. Além disso, durante este processo as ROS podem ser lançadas para o meio extracelular, gerando danos concomitantes à estrutura dos fagócitos, bem como aos tecidos adjacentes (SAKER, 2006).

Estudos conduzidos neste laboratório por Hueza et al. (2007), em frangos de corte tratados com baixas concentrações de S. occidentalis na ração $(0,25 \%, 0,50 \%$ e $0,75 \%$ ), apontaram alterações na fagocitose de macrófagos peritoneais e no metabolismo oxidativo induzidos pela planta. De modo similar, utilizando-se ratos adultos tratados com $1 \%, 2 \%$ e $4 \%$ de sementes da planta na ração, durante nossa Dissertação de Mestrado, foram observadas diminuição no metabolismo oxidativo nos animais tratados com So4 (MARIANO-SOUZA, 2005).

Na presente pesquisa também foram encontradas alterações neste parâmetro nos ratos expostos a So4, tanto por 14 dias, quanto por 28 dias, os quais apresentaram diminuição do burst oxidativo basal, bem como na fagocitose de neutrófilos. Porém, estas alterações não foram detectadas naqueles animais pertencentes ao grupo PF. Assim, ao reunir estes achados: redução do burst oxidativo, diminuição da intensidade e da porcentagem da fagocitose e menor número de neutrófilos circulantes, observados na leitura diferencial, pode-se reforçar a hipótese de que os efeitos tóxicos produzidos pela planta induzem supressão da resposta imune inata nestes animais, como já demonstrada em estudos precedentes conduzidos com a S. occidentalis (SILVA et al.,2003; HUEZA et al., 2007). 
As avaliações dos órgãos linfóides no presente estudo sugerem claramente o efeito imunossupressor produzido pela $S$. occidentalis em ratos recém-desmamados. Paradoxalmente, uma pesquisa conduzida por Bin-Hafeez et al. (2001), administrando o extrato aquoso desta mesma planta a camundongos, por duas semanas consecutivas, propôs que a $S$. occidentalis tenha um potente efeito imunoprotetor.

Deve-se considerar que, embora alguns constituintes químicos presentes nas espécies de Senna, como os senosídeos, apresentem propriedades hidrofilicas, outros componentes, como os flavonóides, glicosídeos esteróides e alguns glicosídeos antraquinônicos (O-glicosídeos e geninas) são hidrofóbicos (KIM et al., 1971; MEDOUA; MBOFUNG, 2007). Além disso, estudos demonstram que tanto os efeitos tóxicos, quanto os terapêuticos induzidos pela $S$. occidentalis são dependentes de uma complexa interação sinérgica entre os agentes fitoquímicos que estão distribuídos em concentrações distintas, nas várias partes da planta (DE WITTE 1993; BRUSICK; MENGS, 1997; SILVA et al., 2008). Deste modo, é plausível supor que a discrepância encontrada entre os resultados aqui obtidos e aqueles encontrados por Bin-Hafeez et al. (2002), deve-se ao fato de que naquele trabalho anterior os pesquisadores trabalharam com o extrato aquoso obtido a partir de folhas da planta; dessa maneira, provavelmente os princípio(s) ativo(s) tóxico(s) não se encontravam neste tipo de extração. Além disto, deve-se considerar que embora todas as partes da S. occidentalis sejam tóxicas, é na semente onde estão contidas maiores concentrações de princípios ativos tóxicos (HENSON et al., 1965; MERCER et al., 1967). Como aqueles autores utilizaram somente as folhas, é factível supor que não havia naquele extrato alguma toxina, como a antraquinona, que pudesse acarretar injúria no sistema imune do animal, como aqui observado. 
Esta pesquisa procurou abordar, ainda, a exposição a $S$. occidentalis em fêmeas gestantes, bem como na prole de fêmeas tratadas com a planta, como recomendado pelas agências regulamentadoras (OECD, 2001; FDA, 1999; EPA, 2002; EMEA, 2006) em estudos pré-clínicos com xenobióticos.

Em relação à avaliação perinatal da administração de $S$. occidentalis, um estudo conduzido por Tasaka et al. (2004), administrando sementes desta planta a coelhas gestantes, revelou que as proles de mães tratadas apresentavam nos hepatócitos, dilatação mitocondrial com destruição das cristas internas, lesão esta muito semelhante àquela verificada em coelhos adultos. Este fato permitiu sugerir que a diantrona tivesse passagem transplacentária, promovendo assim, este efeito direto no feto. Subsequentemente, um estudo conduzido por Barbosa-Ferreira (2008), ao administrar sementes de S. occidentalis a cabras gestantes, verificou que os filhotes destas mães, embora não manifestassem alterações morfológicas, apresentaram deficit de aprendizado, ao serem avaliados por testes neurocomportamentais.

A presente pesquisa visou avaliar o possível impacto da(s) toxina(s) presente(s) na S. occidentalis, na prole de fêmeas tratadas com a planta durante a gestação; no entanto, avaliando-se o sistema imune e hematopoiético.

A imunotoxicologia do desenvolvimento (DIT) é uma subárea da imunotoxicologia, que visa avaliar as manifestações tóxicas, decorrentes da exposição aos xenobióticos durante qualquer período de vida do organismo em formação (LADICS et al., 2005; BELLINGER, 2005; KUSHIMA et al., 2007; DIETERT, 2009). Os estudos mais incisivos relatando a maior sensibilidade do organismo imaturo aos efeitos tóxicos causados pelos xenobióticos, em comparação com o organismo adulto, surgiram na metade da década de 1970 (CHAPMAN; 
ROBERTS, 1984). Nesta direção, várias pesquisas subseqüentes demonstraram de maneira consistente o acometimento do sistema imune de animais jovens (recémnascidos, recém-desmamados, pré-púberes e púberes), utilizando diferentes xenobióticos como o diazepam (DESCOTES; TEDONE; EVREUX, 1982), aciclovir (STAHLMANN et al., 1992), ciclofosfamida (HESSEL et al., 1994), dexametasona (BAKKER et al., 2000), dietilbestrol (PIERSMA et al.,2001), extrato de carqueja (Baccharis trimera) (GRANCE et al., 2008), entre outros.

De acordo com Landreth (2002), a exposição a xenobióticos durante a gestação determina uma resposta sistêmica de estresse oxidativo materno, que compromete a estabilização da resposta imune inata do concepto, aumentando a suscetibilidade dos mesmos a infecções.

É sabido que o oxigênio é essencial para a vida dos organismos aeróbios, assim como a geração das ROS é necessária para a manutenção de importantes processos fisiológicos, como a reparação do DNA durante a fase de replicação deste ácido nucléico; é fato que uma função orgânica ótima seja baseada no equilíbrio nos níveis das ROS (KOVACIC; SOMANATHAN, 2008). Portanto, toda vez que a formação das ROS excede a proteção oxidante ou não é responsiva, deve-se considerar a ocorrência de desordens genéticas, bem como metabólicas de ordem tóxicas, que incidiam em danos celulares devido à injúria mitocondrial (KOVACIC et al., 2005).

$\mathrm{Na}$ presente pesquisa, aqueles filhotes de mães tratadas com So4 apresentaram exacerbação do burst oxidativo; paradoxalmente a intensidade de fagocitose dos neutrófilos desta prole estava diminuída. Portanto, pode-se supor que estas alterações estejam relacionadas a desordens de origem mitocondrial e fagocitose ineficiente pelos neutrófilos, possivelmente de ordem congênita inerentes 
aos efeitos tóxicos promovidos pela S. occidentalis nas mitocôndrias. No entanto, deve-se considerar que os filhotes de mães do grupo PF também apresentaram alteração neste parâmetro. Assim, neste momento ainda não é possível imputar os efeitos verificados no burst oxidativo, exclusivamente ao efeito tóxico produzido pela planta.

Além disto, verificou-se que a prole de mães tratadas com a planta apresentou manifestações hematológicas. No entanto, foram observadas estas mesmas alterações naqueles filhotes provenientes de ratas do grupo PF. Portanto, da mesma maneira que o concluído em relação aos dados relativos ao burst oxidativo, seria precoce, neste momento, atribuir este achado à ação de algum princípio tóxico presente na planta. Assim, estudos posteriores devem ser realizados, com o objetivo de melhor esclarecer estes achados.

O presente trabalho revelou que, em relação à toxicidade promovida pela $S$. occidentalis, os ratos recém-desmamados foram aqueles que apresentaram as manifestações tóxicas mais sutis, pois os mesmos não demonstravam debilidades físicas de forma evidente, como observada em ratos adultos; entretanto, somente com a análise dos parâmetros do sistema imune é que se verificou a maior suscetibilidade dos mesmos.

Contudo, existe uma estreita correlação entre o sistema imune inato dos animais recém-desmamados e adultos, e os toxicantes presentes na S. occidentalis. Estes, indubitavelmente geram danos mitocondriais, especialmente nos órgãos com maior demanda de oxigênio (CALORE et al.,1997; HARAGUCHI et al., 1998; TASAKA et al., 2000).

Portanto, o tropismo dos princípios ativos tóxicos sobre as células da medula óssea em animais recém-desmamados, no presente trabalho, justifica o 
aparecimento de anemia em ratos adultos, anteriormente observada em nossa Dissertação de Mestrado. Conseqüentemente, o aumento no tamanho do baço aqui descrito, em ratos recém-desmamados, estaria relacionado ao aumento da proliferação hematopoiética extramedular compensatória aos efeitos tóxicos produzidos nas mitocôndrias dos progenitores eritróides.

Concluindo, o presente estudo gerou um conjunto de dados substanciais em relação aos efeitos tóxicos promovidos pela $S$. occidentalis sobre o sistema imune de animais jovens, bem como na prole de mães expostas à ração contendo a planta. A implementação do protocolo de 28 dias de tratamento possibilitou um maior esclarecimento a respeito da toxicidade indireta da planta sobre a medula óssea, associada ao aumento do baço verificado tanto nos animais desta pesquisa, quanto naqueles de estudos precedentes. A presente investigação demonstrou também que a inclusão de um grupo de animais PF neste tipo de protocolo experimental contribui de forma evidente para diferenciar as desordens nutricionais daquelas promovidas por toxicantes, em estudos desta natureza. Assim sendo, uma importante sugestão, oriunda desta pesquisa, é a inclusão de um grupo PF naqueles protocolos de imunotoxicidade propostos pelas principais agências regulamentadoras de avaliação de risco. 
Conclusões 198

\section{CONCLUSÕES}




\section{CONCLUSÕES}

- É provável que a queda no consumo de ração por aqueles ratos recémdesmamados, provenientes dos diferentes grupos expostos à S. occidentalis, esteja diretamente relacionada aos efeitos tóxicos da planta e não com sua baixa palatabilidade;

- A diminuição no ganho de peso dos ratos recém-desmamados, tratados com as maiores concentrações de $S$. occidentalis, não estaria exclusivamente relacionada ao menor consumo de ração, mas também em função da ação do(s) princípio(s) ativo(s) tóxico(s) desta planta, que provavelmente deve(m) interferir negativamente no metabolismo animal;

- A ação da S. occidentalis foi capaz de alterar o funcionamento normal do sistema hematológico dos ratos recém-desmamados, tratados com a maior concentração de sementes da planta, induzindo à anemia microcítica e hipocrômica;

- A diminuição da celularidade da medula óssea dos ratos recém-desmamados, tratados com as maiores concentrações de sementes da planta, seria devida à toxicidade indireta no sistema hematopoiético;

- A intoxicação por S. occidentalis foi capaz de promover alterações nos órgãos linfóides de ratos tratados com as maiores concentrações, acarretando redução no peso relativo do timo (So2 e So4) e no baço (So4); 
- A S. occidentalis induziu à proliferação hematopoiética extra-medular e ao aumento de megacariócitos multinucleados no baço de ratos recémdesmamados tratados com a maior concentração de sementes;

- A S. occidentalis interferiu na resposta imune inata dos ratos recémdesmamados, tratados com a maior concentração de sementes da planta, devido à diminuição do burst oxidativo e da fagocitose de neutrófilos;

- A S. occidentalis produziu toxicidade no baço da prole de mães tratadas, induzindo proliferação hematopoiética extra-medular, com presença de megacariócitos multinucleados;

- $\quad$ aumento do burst oxidativo na prole de mães tratadas com a S. occidentalis durante a gestação provavelmente está relacionado aos efeitos tóxicos desta planta;

- A presença de um grupo peer-feeding mostrou ser fundamental para melhor avaliar a influência do estado nutricional sobre todos os parâmetros de imunotoxicidade aqui avaliados. 
Referências 201

REFERÊNCIAS 


\section{REFERÊNCIAS}

ABATAN, M. O.; LATEEF, I.; TAIWO, V. O. Toxic Effects of Non-Steroidal AntiInflammatory Agents in Rats. African Journal of Biomedical Research, v. 9, $n$ 1., p. 219-223, 2006.

ACCORSI, W. R. Medicina natural, um novo conceito. A fórmula: guia de negócios. v. 2 , n. 4 , p. $5,2000$.

ADAM, S. E.I.; AL-YAHYA, M. A.; AL-FARHAN, A. H. Combined toxicity of Cassia occidentalis and Citrullus colocynthis in rats. Veterinary and Human Toxicology, v. 43, n. 2, p. 70-72, 2001.

AFONSO, E. POTT. A. (Ed.). Plantas no Pantanal tóxicas para bovinos. Corumbá: EMBRAPA-CPAP / Brasília: EMBRAPA-SPI, 2002. 320 p.

AGARWAL, R.; DIWANAY, S.; PATKI, P.; PATWARDHAN, B. Studies on immunomodulatory activity of Withania somnifera (Ashwagandha) extracts in experimental immune inflammation. Journal of Ethnopharmacology, v. 67, n. 1, p. 27-35, 1999.

AKBAS, S. H.; OZDEM, S.; CAGLAR, S.; TUNCER, M.; GURKAN, A.; YUCETIN, L.; SENOL, Y.; DEMIRBAS, A.; GULTEKIN, M.; ERSOY, F. F.; AKAYDIN, M. Effects of some hematological parameters on whole blood tacrolimus concentration measured by two immunoassay-based analytical methods. Clinical Biochemistry, v. 38, n. 6, p. 552-557, 2005. 
AL-YAHYA, M. A.; AL-FARHAN, A. H.; ADAM, S. E. Toxicological interactions of Cassia senna and Nerium oleander in the diet of rats. The American Journal of Chinese Medicine, v. 30, n. 4, p. 579-587, 2002.

ANVISA. AGÊNCIA NACIONAL DE VIGILÂNCIA SANITÁRIA. Resolução RDC $\mathbf{n}^{\circ}$ 48, de 16 de março de 2004, Brasil. Dispõe sobre o registro de medicamentos fitoterápicos.

ARNOUS, A. H.; SANTOS, A. S.; BEINNER, R. P. C. Plantas medicinais de uso caseiro - conhecimento popular e interesse por cultivo comunitário. Revista Espaço para a Saúde, Londrina, v. 5, n. 2, p. 1-6, 2005.

BAILEY, L. H. (Ed.). Manual of cultivated plants. New York: Macmilan, 1977. p. 17.

BAKKER, J. M.; KAVELAARS, A.; KAMPHUIS, P. J.; COBELENS, P. M.; VAN VUGT, H. H.; VAN BEL, F.; HEIJNEN, C. J. Neonatal dexamethasone treatment increases susceptibility to experimental autoimmune disease in adult rats. Journal Immunology, v. 165, n. 10, p. 5932-5937, 2000.

BARBOSA-FERREIRA, M. Proposta de modelo para o estudo de toxicologia perinatal em ruminantes: Avaliação dos efeitos tóxicos da Senna occidentalis em caprinos São Paulo. 2008. 185 f. Tese (Doutorado em Ciências). Faculdade de Medicina Veterinária e Zootecnia da Universidade de São Paulo, São Paulo, 2008.

BARBOSA-FERREIRA, M.; DAGLI, M. L.; MAIORKA, P. C.; GORNIAK, S. L. Subacute intoxication by Senna occidentalis seeds in rats. Food and Chemical Toxicology, v. 43, n. 4, p. 497-503, 2005. 
BARRETO, B. B. GOMES, F. V. TEIXEIRA, J. B. P. O uso de plantas medicinais por comunidades carentes no município de Juiz de Fora (MG). In: Semana de Biologia, 29; Mostra de Produção Científica, 12, 2006, Juiz de Fora, MG. Resumos...2006, v.1, p. 050.

BARROS, C. S. L. Intoxicação por plantas que afetam o sistema muscular intoxicação por Senna occidentalis. In: RIET-CORREA, F.; MENDEZ, M. C.; SCHILD, A. IL. (Ed.). Intoxicação por plantas e micotoxicoses em animais domésticos. Pelotas: Hemisfério Sul do Brasil, 1991. p. 201-223.

BARROS, C. S. L.; ILHA, M. R. S.; BEZERRA J. R., P. S.; LANGOHR, I. M.; KOMMERS, G. D. Intoxicação por Senna occidentalis (Leg. Caesalpinoideae) em bovinos em pastoreiro. Pesquisa Veterinária Brasileira, v. 19, n. 3/4, p. 68-70, 1999.

BARROS, C. S. L.; PILATI, C.; ANDUJAR, M. B.; GRAÇA, D. L.; IRIGOYEN, L. F.; LOPES, S. T.; SANTOS, C. F. Intoxicação por Cassia occidentalis (Leg Caesalpinoideae) em bovinos. Pesquisa Veterinária Brasileira, v. 10, n. 1, p. 4758, 1990.

BARROW, P. C.; RAVEL, G. Immune assessments in developmental and juvenile toxicology: practical considerations for the regulatory safety testing of pharmaceuticals. Regulatory Toxicology and Pharmacology, v. 43, n. 1, p. 3544, 2005.

BATISTA, F. D.; HARWOOD, N. E. The who, how and where of antigen presentation to B cells. Nature Reviews Immunology, v. 9, n. 1, p. 15-27, 2009. 
BELLINGER, D. C. Teratogen update: lead and pregnancy. Birth Defects Research. Part A, Clinical and molecular teratology, v. 73, n. 6, p. 406-420, 2005.

BEUERS, U.; SPENGLER, U.; PAPE, G. R. Hepatitis after chronic abuse of Senna. The Lancet, v. 337, n. 8737, p. 372-373, 1991.

BIN-HAFEEZ, B.; AHMAD, I.; HAQUE, R.; RAISUDDIN, S. Protective effect of Cassia occidentalis $\mathrm{L}$. on cyclophosphamide-induced suppresion of humoral immunity in mice. Journal of Ethnopharmacology, v. 75, n. 1, p. 13-18, 2001.

BIRGEL, E. H. Hematologia clínica veterinária. In: BIRGEL, E. H.; BENESI, F. J. (Ed.). Patologia clínica veterinária. São Paulo: Sociedade Paulista de Medicina Veterinária, 1982. p. 2-34.

BORELLI, P.; S.L, B.; ROGERO, M. M.; FOCK, R. A. Haematological alterations in protein malnutrition. Revista Brasileira de Hematologia e Hemoterapia, v. 26, n. 1, p. 49-56, 2004.

BOTHA, C. J.; PENRITH, M. L. Poisonous plants of veterinary and human importance in southern Africa. Journal of Ethnopharmacology, v. 119, n. 3, p. 549-558, 2008.

BOTSARIS, A. S.; BOORHEM, R. L.; CORREAA, C. B. V. Fitoterapia chinesa e plantas brasileiras. São Paulo: Cone, 1995. 700 p.

BRANDÃO, M. G. L. Plantas Medicinais. In: GUERRA, C. B.; BARBOSA, F. A. R. (Org.). Programa de educação ambiental na Bacia do Rio Piracicaba. Belo Horizonte: Editora da UFMG, 1996. p.173-193. 
BRUSICK, D.; MENGS, U. Assessment of the genotoxic risk from laxative Senna products. Environmental and Molecular Mutagenesis, v. 29, n. 1, p. 1-9, 1997.

BURNS-NASS, L. A.; MEADE, J.; MUNSON, A. E. Toxic responses of the immune system. In: KLAASSEN, C. D. (Ed.). Casarett and Doull's toxicology: the basic science of poisons. 6th ed. New York: Mc Graw-Hill, 2000. p. 419.

CALIXTO, J. B. Efficacy, safety, quality control, marketing and regulatory guidelines for herbal medicines (phytotherapeutic agents). Brazilian Journal of Medical and Biological Research, v. 33, n. 2, p. 179-189, 2000.

CALORE, E. E.; CAVALIERE, M. J.; HARAGUCHI, M.; GÓRNIAK, S. L.; DAGLI, M. L. Z.; RASPANTINI, P. C. F.; CALORE, N. M. P. Experimental mitochondrial myopathy induced by chronic intoxication by Senna occidentalis seeds. Journal of Neurological Sciences, v. 146, n. 1, p. 1-6, 1997.

CALORE, E. E.; CAVALIERE, M. J.; HARAGUCHI, M.; GÓRNIAK. S. L.; DAGLI, M. L. Z.; RASPANTINI, P. C. F.; CALORE, N. M. P.; WEG, R. Toxic peripheral neuropathy of chicks feed Senna occidentalis seeds. Ecotoxicology and Environmental Safety, v. 39, n. 1, p. 27-30, 1998.

CAVALIERI, M. J.; CALORE, E. E.; HARAGUCHI, M.; GÓRNIAK, S. L.; DAGLI, M. L. Z.; RASPANTINI, P. C. F.; CALORE, N. M.; WEG, R. Mitochondrial myopathy in Senna occidentalis feed chicken. Ecotoxicology and Environmental Safety, v. 37, n. 2, p. 181-185, 1997.

CHAPMAN, J. R.; ROBERTS, D. W. Humoral immune dysfunction as a result of prenatal exposure to diphenylhydantoin: correlation with the occurrence of physical defects. Teratology. v. 30, n. 1, p. 107-117, 1984. 
CHEEKE, P. R. (Ed.). Toxicants in feeds, Forages, and Poisonous Plants. Danville: Interstate Publishers, 1998. 479 p.

CHOPRA, R. N., NAYER, S. L. (Ed.). Glossary of Indian Medicinal Plant. Council of Scientific and Industrial Research: New Delhi, 1980. 55 p.

CHURIN, A. A.; GOLDBERG, V. E.; KARPOVA, G. V.; VORONOVA, O. L.; FEODOROVA, E. P.; KOLOTOVA, O. V.; SKURIKHIN, E. G.; PERSHINA, O. V. Reaction of bone marrow hematopoiesis to the toxic effect of paclitaxel. Bulletin of Experimental Biology and Medicine, v. 145, n. 2, p. 213-217, 2008.

CIMEN, M. Y. Free radical metabolism in human erythrocytes. Clinical Chimica Acta, v. 390, n. 1-2, p. 1-11, 2008.

CLOUATRE, D. L. Kava-kava: examining new reports of toxicity. Toxicology Letters, v. 150, n. 1, p. 85-96, 2004.

COLVIN, B. M.; HARRISON, L. R.; SANGSTER, L. T.; GOSSER, H. S. Cassia occidentalis toxicosis in growing pigs. Journal of American Veterinary Medical Association, v. 189, n. 4, p. 423-426, 1986.

CRAGG, G. M.; NEWMAN, D. J. Medicinals for the millennia: the historical record. Annals of the New York Academy of Sciences, v. 953, n.1, p. 3-25, 2001.

CUI, L.; ZHOU, Q. F.; LIAO, C. Y.; FU, J. J.; JIANG, G. B. Studies on the toxicological effects of PFOA and PFOS on rats using histological observation and chemical analysis. Archives of Environmental Contamination and Toxicology, v. 56, n. 2, p. 338-349, 2009. 
DE JONG, W. H.; VAN LOVEREN, H. Screening of xenobiotics for direct immunotoxicity in an animal study. Methods, v. 41, n. 1, p. 3-8, 2007.

DE ONIS, M. Measuring nutritional status in relation to mortality. Bulletin of the World Health Organization, v. 78, n. 10, p. 1271-1274, 2000.

DE WITTE, P. Metabolism and pharmacokinetics of anthranoids. Pharmacology, v. 47, p. $86-97,1993$. Supplement, 1.

DESCOTES, J. Immunotoxicology: role in the safety assessment of drugs. Drug Safety Journal, v. 28, n. 2, p. 127-136, 2005.

DESCOTES, J.; TEDONE, R.; EVREUX, J. C. Suppression of humoral and cellular immunity in normal mice by diazepam. Immunology Letters, v. 5, n. 1, p. 41-42, 1982.

DI ROSA, F. T-lymphocyte interaction with stromal, bone and hematopoietic cells in the bone marrow. Immunology and Cell Biology, v. 87, n. 1, p. 20-29, 2009.

DIETERT, R. R. Developmental immunotoxicology: focus on health risks. Chemical Research in Toxicology, v. 22, n. 1, p. 17-23, 2009.

DIETERT, R. R.; HOLSAPPLE, M. P. Methodologies for developmental immunotoxicity (DIT) testing. Methods, v. 41, n. 1, p. 123-131, 2007.

DOLLAHITE, J. W.; HENSON, J. B. Toxic plants as the etiologic agent of myophaties in animals. American Journal of Veterinary Research, v. 26, n. 112, p. 749-752, 1965. 
DOMINGUEZ-GERPE, L.; REY-MENDEZ, M. Evolution of the thymus size in response to physiological and random events throughout life. Microscopy research and Technique, v. 62, n. 6, p. 464-476, 2003.

DRELA, N. Xenobiotic-induced alterations in thymocyte development. Apmis, v. 114, n. 6, p. 399-419, 2006.

DU, X. F.; JIANG, C. Z.; WU, C. F.; WON, E. K.; CHOUNG, S. Y. Synergistic immunostimulating activity of pidotimod and red ginseng acidic polysaccharide against cyclophosphamide-induced immunosuppression. Archives of Pharmacal Research, v. 31, n. 9, p. 1153-1159, 2008.

DUGAN, G. M.; GUMBMANN, M. R. Toxicological evaluation of sicklepod and black nightshade seeds in short-term feeding studies in rats. Food and Chemical Toxicology, v. 28, n. 2, p. 101-107, 1990.

ELMORE, S. A. Enhanced histopathology of the bone marrow. Toxicology Pathology, v. 34, n. 5, p. 666-686, 2006.

EL-SAYED, N. Y.; ABDELBARI, E. M.; MAHMOUD, O. M.; ADAM, S. E. I. The toxicity of Cassia senna in Nubian goats. The Veterinary Quarterly, v. 45, n. 2, p. 80-85, 1993.

EMEA. EUROPEAN MEDICINES AGENCY. Guideline on similar biological medicinal products containing biotechnology-derived proteins as active substance: non-clinical and clinical issues, London February 22, 2006. Preauthorisation Evaluation of Medicines for Human Use. 
ENGLER, R. J.; WITH, C. M.; GREGORY, P. J.; JELLIN, J. M. Complementary and alternative medicine for the allergist-immunologist: where do I start? The Journal of Allergy and Clinical Immunology, v. 123, n. 2, p. 309-316, 2009.

EPA. ENVIRONMENTAL PROTECTION AGENCY. Guidelines for reproductive toxicity risk assessment, Washington DC October 31, 1996.

FAKEYE, T. O.; PAL, A.; BAWANKULE, D. U.; YADAV, N. P.; KHANUJA, S. P. Toxic effects of oral administration of extracts of dried calyx of Hibiscus sabdariffa Linn. (Malvaceae). Phytotherapy Research, v. 23, n. 3, p. 412-416, 2009.

FANG, X.; ZHANG, L.; FENG, Y.; ZHAO, Y.; DAI, J. Immunotoxic effects of perfluorononanoic acid on BALB/c mice. Toxicological Sciences, v. 105, n. 2, p. 312-321, 2008.

FDA. FOOD AND DRUG ADMINISTRATION. Reviewer Guidance. Evaluation of human pregnancy outcome data. 1999. Disponível em: www.fda.gov/cder/guidance/2377dft. Acesso em: fev. 2008.

FERREIRA, E. I. Como nascem e se desenvolvem os novos medicamentos. In: SILVA, P. (Ed.). Farmacologia. Rio de Janeiro: Guanabara Koogan, 2002. p. 200208.

FORTOUL, T. I.; PIÑÓN-ZARATE, G.; DIAZ-BECH, M. E.; GONZÁLEZ-VILLALVA, A.; MUSSALI-GALANTE, P.; RODRIGUEZ-LARA, V.; COLIN-BARENQUE, L.; MARTINEZ-PEDRAZA, M.; MONTAÑO, L. F. Spleen and bone marrow megakaryocytes as targets for inhaled vanadium. Histology and Histopathology, v. 23 , n. 11, p. 1321-1326, 2008. 
FUGH-BERMAN, A. Herb-drug interactions. Lancet, v. 355, n. 9198, p. 134-138, 2000.

FUKUDA, I.; KANEKO, A.; NISHIUMI, S.; KAWASE, M.; NISHIKIORI, R.; FUJITAKE, N.; ASHIDA, H. Structure-activity relationships of anthraquinones on the suppression of DNA-binding activity of the aryl hydrocarbon receptor induced by 2,3,7,8-tetrachlorodibenzo-p-dioxin. Journal of Bioscience and Bioengineering, v. 107 , n. 3, p. 296-300, 2009.

FURZE, R. C.; RANKIN, S. M. Neutrophil mobilization and clearance in the bone marrow. Immunology, v. 125, n. 2, p. 281-288, 2008.

GAD, S. C.; WEIL, C. S. Statistics for toxicologists. In: HAYES, A. W. (Ed.). Principles and methods of toxicology. New York: Raven Press, 1989. p. 435483.

GALE, R. P. Myelosuppressive effects of antineoplastic chemotherapy. In: TESTA, N. G.; GALE, R. P. (Ed.). Hematopoesis. Long-term effects of chemotherapy. New York: Marcel Dekker, 1988. p. 63-73.

GERLACK, L. F.; MORRONE, F. B. Perfil de utilização de composto emagrecedor em farmácia de manipulação de Porto Alegre. Infarma, v. 78, n. 7/8, p. 21-24, 2006.

GILL, J.; MALIN, M.; SUTHERLAND, J.; GRAY, D.; HOLLANDER, G.; BOYD, R. Thymic generation and regeneration. Immunological Reviews, v. 195, n. 1, p. 2850, 2003. 
GONZÁLEZ-VILLALVA A, FORTOUL TI, AVILA-COSTA MR, PIÑÓN-ZARATE G, RODRIGUEZ-LARAA V, MARTÍNEZ-LEVY G, ROJAS-LEMUS M, BIZARRONEVAREZ P, DÍAZ-BECH P, MUSSALI-GALANTE P, COLIN-BARENQUE L. Thrombocytosis induced in mice after subacute and subchronic V2O5 inhalation. Toxicol Ind Health, v. 22, p.113-116, 2006.

GRANCE, S. R.; TEIXEIRA, M. A.; LEITE, R. S.; GUIMARAES, E. B.; DE SIQUEIRA, J. M.; DE OLIVEIRA FILIU, W. F.; DE SOUZA VASCONCELOS, S. B.; DO CARMO VIEIRA, M. Baccharis trimera: effect on hematological and biochemical parameters and hepatorenal evaluation in pregnant rats. Journal Ethnopharmacology, v. 117, n. 1, p. 28-33, 2008.

GRAPHPAD INSTAT. Instat guide to choosing and interpreting statistical tests, version 3.00. San Diego, 1998. Disponível em: <http://www.graphpad.com>. Acesso em: 23 mar. 2004.

GRAPHPAD PRISM. Graphpad software. Version 3.00. San Diego, 1999. Disponível em: < http://www.graphpad.com>. Acesso em: 23 mar. 2004.

GRAZIANO, M. J.; FLORY, W.; SEGER, C. L.; HERBERT, C. D. Effects of Cassia occidentalis extract in the domestic chicken (Gallus domesticus). American Journal of Veterinary Research, v. 44, n. 7, p. 1238-1244, 1983.

GUEST, I.; UETRECHT. J. Drugs toxic to the bone marrow that target the stromal cells. Immunopharmacology, v. 46, n. 2, p. 103-112, 2000.

HALBERSTEIN, R. A. Medicinal plants: historical and cross-cultural usage patterns. Annals of Epidemiology, v. 15, n. 9, p. 686-699, 2005. 
HARAGUCHI, M. Plantas tóxicas de interesse na pecuária. Biológico, v. 65, n. 1/2, p. 37-39, 2003.

HARAGUCHI, M.; GÓRNIAK, S. L.; CALORE, E. E.; CAVALIERE, M. J.; RASPANTINI, P. C. F.; CALORE, N. M. P.; DAGLI, M. L. Z. Muscle degeneration in chickens caused by Senna occidentalis seeds. Avian Pathology, v. 27, n. 4, p. 346-351, 1998.

HARAGUCHI, M.; GÓRNIAK, S. L.; DAGLI, M. L. Z.; FORMIGONE, F.; RASPANTINI, P. C. F. Determinação dos constituintes químicos das frações tóxicas de fedegoso (Senna occidentalis (L.). In: REUNIÃO ANUAL DA SOCIEDADE BRASILEIRA DE QUÍMICA, 19, Poços de Caldas, MG. 1996. Anais... v.1, p. 096.

HARVEY, J. W. The erythrocyte: physiology, metabolism, and biochemical disorders. In: KANEKO, J. J. Clinical biochemistry of domestic animals. San Diego: Academic Press, 1996.

HASUI, M.; HIRABAYASHI, Y.; KOBAYASHI, Y. Simultaneous measurement by flow cytometry of phagocytosis and hydrogen peroxide production of neutrophils in whole blood. Journal of Immunological Methods, v. 117, n. 1, p. 53-58, 1989.

HEATON, K. W.; CRIPPS, H. A. Straining at stool and laxative taking in an English population. Digestive Diseases and Sciences, v. 38, n. 6, p. 1004-1008, 1993.

HENSON, J. B.; DOLLAHITE, J. W.; BRIDGES, C. H.; RAO, R. R. Myodegeneration in cattle grazing Cassia species. Journal of the American Veterinary Medical Association, v. 147, n. 2, p. 142-145, 1965. 
HERBERT, C. D.; FLORY, W.; SEGER, C.; BLANCHARD, R. E. Preliminary isolation of a myodegenerative toxic principle from Cassia occidentalis. American Journal of Veterinary Research, v. 44, n. 7, p. 1370-1374, 1983.

HESSEL, E. M.; VERHOEF, A.; VAN LOVEREN, H.; PIERSMA, A. H. Minimal immunological changes in structurally malformed rats after prenatal exposure to cyclophosphamide. Toxicology, v. 92, n. 1-3, p. 287-299, 1994.

HOAGLAND, H. C. Hematologic complications of cancer chemotherapy. Seminary of Oncology, v. 9, n. 1, p. 95-102, 1982.

HOEHNE, F. C. Plantas e substâncias vegetais tóxicas e medicinais. São Paulo: Departamento de Botânica do Estado de São Paulo, 1939. p. 140-149.

HU, Z.; YANG, X.; HO, P. C.; CHAN, S. Y.; HENG, P. W.; CHAN, E.; DUAN, W.; $\mathrm{KOH}, \mathrm{H}$. L.; ZHOU, S. Herb-drug interactions: a literature review. Drugs, v. 65, n. 9, p. 1239-1282, 2005.

HUANG, G.; LIU, Y.; CHANG, H.; ZHANG, X.; REN, D.; WILSON, J. X.; CAO, X. Effects of genistein on oxidative injury in endothelial cells. Journal of Nutritional Science and Vitaminology, v. 54, n. 5, p. 402-408, 2008.

HUEZA, I. M.; LATORRE, A. O.; RASPANTINI, P. C.; RASPANTINI, L. E.; MARIANO-SOUZA, D. P.; GUERRA, J. L.; GÓRNIAK, S. L. Effect of Senna occidentalis seeds on immunity in broiler chickens. Journal of Veterinary Medicine. A, Physiology, Pathology, Clinical Medicine, v. 54, n. 4, p. 179-185, 2007. 
IIZUKA, A.; HARITANI, M.; SHIONO, M.; SATO, M.; FUKUDA, O.; HAGIWARA, A.; MIYAZAKI, S.; TANIMURA, N.; KIMURA, K.; NAKAZAWA, K.; KOBAYASHI, M.; TAKAHASHI, T.; SAITO, T.; FUKAI, K. An outbreak of systemic granulomatous disease in cows with high milk yields. The Journal of Veterinary Medical Science / The Japanese Society of Veterinary Science, v. 67, n. 7, p. 693-696, 2005.

IRIGOYEN, L. F.; GRAÇA, D. L.; BARROS, C. S. L. Intoxicação experimental por Cassia occidentalis (leg. Caesalpinoideae) em equinos. Pesquisa Veterinária Brasileira, v. 11, n. 1/2, p. 35-44, 1991.

JACOBS, K. M.; HIRSCH, K. A. Psychiatric complications of Ma-huang. Psychosomatics, v. 41, n. 1, p. 58-62, 2000.

JOLY, A. B. Botânica: introdução à taxonomia vegetal. São Paulo: Editora Nacional, 1977. 777 p.

JOO, J. S.; EHRENPREIS, E. D.; GONZALEZ, L.; KAYE, M.; BRENO, S.; WEXNER, S. D.; ZAITMAN, D.; SECREST, K. Alterations in colonic anatomy induced by chronic stimulant laxatives: the cathartic colon revisited. Journal of Clinical Gastroenterology, v. 26, n. 4, p. 283-286, 1998.

KEIL, D.; DUDLEY, A.; EUDALY, J.; DEMPSEY, J.; BUTTERWORTH, L.; GILKESON, G.; PEDEN-ADAMS, M. Immunological and hematological effects observed in B6C3F1 mice exposed to JP-8 jet fuel for 14 days. Journal of Toxicology and Environmental Health, v. 67, n. 14, p. 1109-1129, 2004.

KIM, H. L.; CAMP, B. J.; GRIGSBY, R. D. Isolation of N-metimorpholine from the seeds of Cassia occidentalis L. (Coffee Senna). Journal of Agricultural Food Chemistry, v. 19, n. 1, p. 198-199, 1971. 
KONAN, N. A.; BACCHI, E. M.; LINCOPAN, N.; VARELA, S. D.; VARANDA, E. A. Acute, subacute toxicity and genotoxic effect of a hydroethanolic extract of the cashew (Anacardium occidentale L.). Journal of Ethnopharmacology, v. 110, n. 1, p. 30-38, 2007.

KOVACIC, P.; POZOS, R. S.; SOMANATHAN, R.; SHANGARI, N.; O'BRIEN, P. J. Mechanism of mitochondrial uncouplers, inhibitors, and toxins: focus on electron transfer, free radicals, and structure-activity relationships. Current medicinal Chemistry, v. 12, n. 22, p. 2601-2623, 2005.

KOVACIC, P.; SOMANATHAN, R. Integrated approach to immunotoxicity: electron transfer, reactive oxygen species, antioxidants, cell signaling, and receptors. Journal of Receptor and Signal Transduction Research, v. 28, n. 4, p. 323346, 2008.

KOVACIC, P.; THURN, L. A. Cardiovascular toxicity from the perspective of oxidative stress, electron transfer, and prevention by antioxidants. Current Vascular Pharmacology, v. 3, n. 2, p. 107-117, 2005.

KRISHNAN, K.; PELEKIS, M. Hematotoxic interactions: occurrence, mechanisms and predictability. Toxicology, v. 105, n. 2-3, p. 355-364, 1995.

KUBY, J. Cells and organs of the immunology system. In: KUBY, J. (Ed.). Immunology. New York: WH Freeman and Co. 1997. p. 47-83.

KUMAR, R. S.; GUPTA, M.; MAZUMDAR, U. K.; RAJESHWAR, Y.; KUMAR, T. S.; GOMATHI, P.; ROY, R. Effects of methanol extracts of Caesalpinia bonducella and Bauhinia racemosa on hematology and hepatorenal function in mice. The Journal of Toxicological Sciences, v. 30 n. 4, p. 265-274, 2005. 
KUSHIMA, K.; ODA, K.; SAKUMA, S.; FURUSAWA, S.; FUJIWARA, M. Effect of prenatal administration of NSAIDs on the immune response in juvenile and adult rats. Toxicology, v. 232, n. 3, p. 257-267, 2007.

LADICS, G. S.; CHAPIN, R. E.; HASTINGS, K. L.; HOLSAPPLE, M. P.; MAKRIS, S. L.; SHEETS, L. P.; WOOLHISER, M. R.; BURNS-NAAS, L. A. Developmental toxicology evaluations-issues with including neurotoxicology and immunotoxicology assessments in reproductive toxicology studies. Toxicological Sciences, v. 88, n. 1, p. 24-29, 2005.

LANDRETH, K. S. Critical windows in development of the rodent immune system. Human \& Experimental Toxicology, v. 21, n. 9-10, p. 493-498, 2002.

LANNING, L. L. Toxicological Pathology Assessment. In: HASCHEK, W. M.; ROSSEAUX, C. G. (Ed.). Fundamental of Toxicology Pathology. Canada: Academic Press., 1998. p. 315-324.

LAWRENCE, D. A.; KIM, D. Central/peripheral nervous system and immune response. Toxicology, v. 142, n. 3, p. 189-291, 2000.

LEE, V. W.; WANG, Y. M.; WANG, Y. P.; ZHENG, D.; POLHILL, T.; CAO, Q.; WU, H.; ALEXANDER, I. E.; ALEXANDER, S. I.; HARRIS, D. C. Regulatory immune cells in kidney disease. American Journal of Physiology. Renal Physiology, v. 295, n. 2, p. 3335-3342, 2008.

LENG-PESCHLOW, E. Sennoside-induced secretion and its relevance for the laxative effect. Pharmacology., v. 47, p. 14-21., 1993. Supplement, 1. 
LIM, A. K.; HOOKE, D. H.; KERR, P. G. Anorexia nervosa and Senna misuse: nephrocalcinosis, digital clubbing and hypertrophic osteoarthropathy. The Medical Journal Of Australia, v. 188, n. 2, p. 121-122, 2008.

LIMA, C. B. Plantas medicinais utilizadas em duas localidades do município de Bandeirantes-PR. 2000. 103 f. (Mestrado em Agronomia) - Universidade Estadual Paulista, Botucatu, Botucatu, 2000.

LORENZI, H. Plantas daninhas do Brasil: terrestres, aquáticas, parasitas, tóxicas e medicinais. Nova Odessa: Plantarum, 1991. 273 p.

LUSTER, M. I.; MUNSON, A. E.; THOMAS, P. T.; HOLSAPPLE, M. P.; FENTERS, J. D.; WHITE JR., K. L.; LAUER, L. D.; GERMOLEC, D. R.; ROSENTHAL, G. J.; DEAN, J. H. Development of a testing battery to assess chemical-induced immunotoxicity: National Toxicology Program's guidelines for immunotoxicity evaluation in mice. Fundamental and Applied Toxicology, v. 10, n. 1, p. 2-19, 1988.

LYDYARD, P.; GROSSI, C. Sistema linfóide. In: ROITT, I.; BROSTOFF, J.; MALE, D. Imunologia. São Paulo: Manole, 1999. p. 31-38.

MARIANO-SOUZA, D. P. Avaliação dos efeitos tóxicos da Senna occidentalis em ratos. Parâmetros bioquímicos, hematológicos, anatomopatológicos e inflamatórios. São Paulo. 2005. 159 f. Dissertação (Mestrado em Ciências). Faculdade de Medicina Veterinária e Zootecnia da Universidade de São Paulo, São Paulo, 2005.

MARTIN, B. W.; TERRY, M. K.; BRIDGES, E. M.; BAILEY, J. R. Toxicity of Cassia occidentalis in the horse. Veterinary and Human Toxicology, v. 23, n. 6, p. 416-417, 1981. 
MARTINAZZO, A. P.; MARTINS, T. Plantas medicinais utilizadas pela população de Cascavel/Pr. Arquivos Ciências Saúde Unipar, v. 8, n. 1, p. 3-5, 2006.

MEDOUA, G. N.; MBOFUNGB, C. M. F. Kinetics studies of some physico-chemical substances during roastingand preparation of beverage made by Cassia occidentalis seeds. LWT- Food Science and Technology, v. 40, n. 3, p. 730-736, 2007.

MERCER, H. D.; NEAL, F. C.; HIMES, J. A.; EDDS, G. T. Cassia occidentalis toxicosis in cattle. Journal of American Veterinary Medical Association, v. 151, n. 6, p. $735-741,1967$.

MOTYKIEWICZ, G.; MICHALSKA, J.; PENDZICH, J.; MALUSECKA, E.; STROZYK, M.; KALINOWSKA, E.; BUTKIEWICZ, D.; MIELZYNSKA, D.; MIDRO, A.; SANTELLA, R. M.; CHORAZY, M. A molecular epidemiology study in women from Upper Silesia, Poland. Toxicology Letters, v. 96-97, n. 1, p. 195-202, 1998.

NADAL, S. R.; CALORE, E. E.; MANZIONE, C. R.; PUGA, F. R.; PEREZ, N. M. Effects of long-term administration of Senna occidentalis seeds in the large bowel of rats. Pathology Research and Practice, v. 199, n. 11, p. 733-737, 2003.

NAKAGE, A. P. M.; MACARI, M.; NAKAGHI, L. S.; MALHEIROS, E. B.; VASQUES, L. H.; SECATO, E. R. Haematological and hormonal studies from broiler chickens fed with corn contaminants: Crotalaria spectabilis and Senna occidentalis.

Brazilian Journal Veterinary Research Animal Science, v. 37, n. 5, p. 377-381, 2000. 
NUNES, G. P.; SILVA, M. F.; RESENDE, U. M.; SIQUEIRA, J. M. Plantas medicinais comercializadas por raizeiros no Centro de Campo Grande, Mato Grosso do Sul. Revista Brasileira de Farmacognosia, v. 13, n. 2, p. 83-92, 2003.

O'HARA, P. J.; PIERCE, K. R. A toxic cardiomyopathy caused by Cassia occidentalis. II. Biochemical studies in poisoned rabbits. Veterinary Pathology, v. 11, n. 12, p. 110-124, 1974a.

O'HARA, P. J.; PIERCE, K. R; READ, W. K. A toxic cardiomyopathy caused by Cassia occidentalis I. Morphlogical studies in poisened rabbits. Veterinary Pathology, v. 11, n. 2, p. 97-109, 1974b.

OECD. ORGANIZANTION FOR ECONOMIC CO-OPERATION AND DEVELOPMENT. Guideline for testing of chemicals. Copenhagen January 22, 2001.

OLIVEIRA, F. Q.; GONÇALVES, L. A. Conhecimento sobre plantas medicinais e fitoterápicos e potencial de toxicidade por usuários de Belo Horizonte, Minas Gerais. Revista Eletrônica de Farmácia, v. 3, n. 2, p. 36-41, 2006.

OMS - ORGANIZACIÓN MUNDIAL DE LA SALUD. Situación regulamentaria de los medicamentos: uma resena mundial. Organización Panamericana de la Salud. Washington: OPAS, 2000. 62p.

ORTIZ, R.; CORTÉS, L.; CORTÉS, E.; MEDINA, H. Malnutrition alters the rates of apoptosis in splenocytes and thymocyte subpopulations of rats. Clinical and Experimental Immunology, v. 155, n. 1, p. 96-106, 2009. 
PAN, L. C.; WILSON, D. W.; SEAL, H. L. Strain differences in the response of Fischer 344 and Sprague-Dawley rats to monocrotaline induced vascular disease. Toxicology, v. 79, n. 1, p. 21-35, 1993.

PAULUHN, J. Subacute inhalation toxicity of aniline in rats: analysis of timedependence and concentration-dependence of hematotoxic and splenic effects. Toxicological Sciencies, v. 81, n. 1, p. 185-215, 2004.

PELAYO, R.; WELNER, R.; PERRY, S. S.; HUANG, J.; BABA, Y.; YOKOTA, T.; KINCADE, P. W. Lymphoid progenitors and primary routes to becoming cells of the immune system. Current Opinion in Immunology, v. 17, n. 2, p. 100-107, 2005.

PERGO, E. M.; ABRAHIM, D.; SOARES DA SILVA, P. C.; KERN, K. A.; DA SILVA, L. J.; VOLL, E.; ISHII-IWAMOTO, E. L. Bidens pilosa L. exhibits high sensitivity to coumarin in comparison with three other weed species. Journal of Chemical Ecology, v. 34, n. 4, p. 499-507, 2008.

PESTKA, J. J. Mechanisms of deoxynivalenol-induced gene expression and apoptosis. Food Additives \& Contaminants. Part A, Chemistry, analysis, control, exposure \& risk assessment, v. 25, n. 9, p. 1128-1140, 2008.

PETTERINO, C.; ARGENTINO-STORINO, A. Clinical chemistry and haematology historical data in control Sprague-Dawley rats from pre-clinical toxicity studies. Experimental Toxicology Patholology, v. 57, n. 3, p. 213-219, 2006.

PIERSMA, A. H.; VERHOEF, A.; TE BIESEBEEK, J. D.; PIETERS, M. N.; SLOB, W. Developmental toxicity of butyl benzyl phthalate in the rat using a multiple dose study design. Reproductive Toxicology, v. 14, n. 5, p. 417-425, 2000. 
PILNY, A. A. Clinical hematology of rodent species The Veterinary Clinics of North America Exotic Animal Practice, v. 11, n. 3, p. 523-533, 2008.

PRENTICE, A. M. The thymus: a barometer of malnutrition. The British Journal of Nutrition, v. 81, n. 5, p. 345-347, 1999.

RAISUDDIN, S. K. P.; ZAIDI, S. I.; SAXENA, A. K.; RAY, P. K. Effects of aflatoxin on lymphoid cells of weanling rat. Journal of Applied Toxicology, v. 10, n. 4, p. 245250, 1990.

REBAR, A. H. General responses of the bone marrow to injury. Toxicology Pathology, v. 21, n. 2, p. 118-129, 1993.

RENISUS. Relação Nacional de Plantas Medicinais de Interesse ao SUS. Ministério da Saúde elabora Relação de Plantas Medicinais de Interesse ao SUS. Brasil, Fevereiro de 2009.

RICH, I. N.; HALL, K. M. Validation and development of a predictive paradigm for hemotoxicology using a multifunctional bioluminescence colony-forming proliferation assay. Toxicological Sciences, v. 87 n. 2, p. 427-441, 2005.

RIER, S. E. Environmental immune disruption: a comorbidity factor for reproduction? Fertility and Sterility, v. 89, n. 2, p. e103-108, 2008. Supplement.

RIET-CORREA, F.; MEDEIROS, R. M. T. Intoxicações por plantas em ruminantes no Brasil e no Uruguai: importância econômica, controle e riscos para a saúde pública. Pesquisa Veterinária Brasileira, v. 21, n. 1, p. 38-42, 2001. 
RIET-CORREA, F.; MÉNDEZ, M. C.; SCHILD, A.L. Intoxicação por plantas e micotoxicoses em animais domésticos. Pelotas: Editorial Hemisfério Sul do Brasil, 1993. 340p.

RITTER, M. R.; SOBIERAJSKI, G. R.; SCHENKEL, E. P.; MENTZ, L. A. Plantas usadas como medicinais no município de Ipê, RS, Brasil. Farmacognosia, v. 12 , n. 2, p. 51-62, 2002.

RODRIGUES, U.; RIET-CORREA, F.; MORAES, N. Intoxicação experimental em suínos com baixas concentrações de Senna occidentalis (Leg. Caesalpinoideae) na ração. Pesquisa Veterinária Brasileira, v. 13, n. 3/4, p. 57-66, 1993.

ROGERS, R. J.; GIBSON, J.; REICHMANN, K. G. The toxicity of Cassia occidentalis for cattle. Australian Veterinary Journal, v. 55, n. 9, p. 408-412, 1979.

ROTH, D. R.; ROMAN, D.; ULRICH, P.; MAHL, A.; JUNKER, U.; PERENTES, E. Design and evaluation of immunotoxicity studies. Experimental Toxicology Pathology, v. 57, n. 5-6, p. 367-371, 2006.

RYTER, S. W.; TYRRELL, R. M. The heme synthesis and degradation pathways: role in oxidant sensitivity. Heme oxygenase has both pro- and antioxidant properties. Free Radic Biol Med, v. 28, p. 289-309, 2000.

SAKER, K. E. Nutrition and immune function. The Veterinary Clinics of North America Small Animal Practice, v. 36, n. 6, p. 1199-1224, 2006.

SAKURAI, T.; OHTA, T.; FUJIWARA, K. Inorganic arsenite alters macrophage generation from human peripheral blood monocytes. Toxicology and applied Pharmacology, v. 203, n. 2, p. 145-153, 2005. 
SANDERSON, B. J. S.; CLARK, A. M. Micronuclei in adult and foetal mice exposed in vivo heliotrine, urethane, monocrotaline and benzidine. Mutation Research, $v$. 285 , n. 1, p. 27-33, 1993.

SANTOS, T. P. S.; MONTEIRO, L. Frequência das anemias microcíticase hipocrômicas no Laboratório Central do Hospital Oswaldo Cruz - Recife, PE. News Lab, v. 87, n. 1, p. 78- 84, 2008.

SAVINO, W. The thymus gland is a target in malnutrition. European Journal of Clinical Nutrition, v. 56, p. S46-49, 2002. Supplement, 3.

SEYBOLD, U.; LANDAUER, N.; HILLEBRAND, S.; GOEBEL, F. D. Senna-induced hepatitis in a poor metabolizer. Annals of International Medicine, v. 141, n. 8, p. 650-651, 2004.

SHEN, S. G.; HUI, L.; ZHAO, Y. Y.; ZHANG, Q. Y.; SUN, H. W. The distribution patterns of trace elements in the blood and organs in a rabbit experimental model of copper pollution and study of haematology and biochemistry parameters. Environmental Toxicology and Pharmacology, v. 19, n. 3, p. 379-384, 2005.

SILVA, C. R.; MONTEIRO, M. R.; ROCHA, H. M.; RIBEIRO, A. F.; CALDEIRA-DEARAUJO, A.; LEITÃO, A. C.; BEZERRA, R. J.; PÁDULA, M. Assessment of antimutagenic and genotoxic potential of senna (Cassia angustifolia Vahl.) aqueous extract using in vitro assays. Toxicology in vitro, v. 22, n. 1, p. 212-128, 2008.

SILVA, T. C.; GÓRNIAK, S. L.; OLORIS, S. C. S.; RASPANTINI, P. C.; HARAGUCHI, M.; DAGLI, M. L. Z. Effects of Senna occidentalis on chick bursa of Fabricius. Avian pathology, v. 32, n. 6, p. 633-637, 2003. 
SIMPSON, C. F.; DAMRON, B. L.; HARMS, R. H. Toxic myopathy of chickens fed Cassia occidentalis seed. Avian Disease, v. 15, n. 2, p. 284-290, 1971.

SOSSAI, P.; NASONE, C.; CANTALAMESSA, F. Are herbs always good for you? A case of paralytic ileum using a herbal tisane. Phytotherapy Research, v. 21, n. 6 , p. 587-588, 2007.

SOYUNCU, S.; CETE, Y.; NOKAY, A. E. Portal vein thrombosis related to Cassia angustifolia. Clinical Toxicology, v. 46, n. 8, p. 774-777, 2008.

SPIVAK, J. L. The blood in systemic disorders. The Lancet, v. 355, n. 9216, p. 17071712, 2000.

STAHLMANN, R.; KORTE, M.; VAN LOVEREN, H.; VOS, J. G.; THIEL, R.; NEUBERT, D. Abnormal thymus development and impaired function of the immune system in rats after prenatal exposure to aciclovir. Archives of Toxicology, v. 66, n. 8, p. 551-559, 1992.

STEYN, D. G. (Ed.). Toxicology of Plants in South Africa. Johannesburg: Central News Agency, 1934. 631p.

STICKEL, F.; SCHUPPAN, D. Herbal medicine in the treatment of liver diseases. Digestive and Liver Disease, v. 39, n. 4, p. 293-304, 2007.

SULIMAN, H. B.; SHOMMEIN, A. M. Toxic effect of the roasted and unroasted beans of Cassia occidentalis in goats. Veterinary and Human Toxicology, v. 28, n. 1, p. 6-11, 1986.

SUTTIE, A. W. Histopathology of the spleen. Toxicology Pathology, v. 34, n. 5, p. 466-503, 2006. 
TASAKA, A. C. Estudo da toxicidade da Senna occidentalis em coelhos. I Avaliação em animais durante a fase de crescimento. II - Efeitos perinatais. São Paulo. 2000. 120 f. Tese (Doutorado em Ciências). Faculdade de Medicina Veterinária e Zootecnia da Universidade de São Paulo, São Paulo, 2000.

TASAKA, A. C.; CALORE, E. E.; CAVALIERE, M. J.; DAGLI, M. L. Z.; HARAGUCHI, M.; GÓRNIAK, S. L. Experimental poisoning in rabbits fed with Senna occidentalis seeds. Veterinary Research Communications, v. 24, n. 8, p. 573-582, 2000.

TENEDINI, E.; FAGIOLI, M.E.; VIANELLI, N.; TAZZARI, P.L.; RICCI, F.;

TAGLIAFICO, E.; RICCI, P.; GUGLIOTTA, L.; MARTINELLI, G.; TURA, S.; BACCARANI, M.; FERRARI, S.; CATANI, L. Gene expression profiling of normal and malignant CD34-derived megakaryocytic cells. Blood, v 104, p. 3126-3135, 2004

TIMM, C. D.; RIET-CORREA, F. Plantas Tóxicas Para Suínos. Ciência Rural, Santa Maria, v. 27, n. 3, p. 521-528, 1997.

TOKARNIA, C. H.; DÖBEREINER, J.; PEIXOTO, P. V. Plantas tóxicas do Brasil. Rio de Janeiro: Helianthus, 2000. 310 p.

TOKARNIA, C. H.; DÖBEREINER, J.; PEIXOTO, P. V. Poisonous plants affecting livestock in Brazil. Toxicon, v. 40 n. 5, p. 1635-1660, 2002.

VAN DER OHE, M. R.; CAMILLERI, M.; KVOLS, L. K.; THOMFORDE, G. M. Motor dysfunction of the small bowel and colon in patients with the carcinoid syndrome and diarrhea. The New England Journal of Medicine, v. 329, n. 15, p. 10731078, 1993. 
VASHISHTHA, V. M.; KUMAR, A.; JOHN, T. J.; NAYAK, N. C. Cassia occidentalis poisoning as the probable cause of hepatomyoencephalopathy in children in western Uttar Pradesh. The Indian Journal of Medical Research, v. 125, n. 6, p. 756-762, 2007.

VEIGA JUNIOR, V. F.; PINTO, A. C.; MACIEL, M. A. M. Plantas medicinais: cura segura? Química Nova, v. 28, n. 3, p. 519-528, 2005.

VICKERY, B. H.; BENNETT, J. P. Reproduction and Breeding Techniques for Laboratory Animals. In: HAFEZ, E. S. E. (Ed.). Rats and mic. Philadelphia: Lea \& Febiger, 1970. p. 229-315.

VOSS, K. A.; BRENNECKE, L. H. Toxicological and hematological effects of sicklepod (Cassia obstusifolia) seeds in Sprague- Dawley rats: a subchronic feeding study. Toxicon, v. 29, n. 11, p. 1319-1336, 1991.

WEG, R. Indução de miopatia tóxica em ratos tratados com sementes de Senna occidentalis. 2001. 70 f. Tese (Doutorado em Ciências). Faculdade de Medicina Veterinária e Zootecnia da Universidade de São Paulo, São Paulo, 2001.

WEST, L. J. Defining critical windows in the development of the human immune system. Human \& Experimental Toxicology, v. 21, n. 3, p. 499 - 505, 2002.

XING, J. H.; SOFFER, E. E. Adverse effects of laxatives. Diseases of the Colon and Rectum, v. 44, n. 8, p. 1201-1209, 2001. 